




\section{DISCLAIMER}

This report was prepared as an account of work sponsored by an agency of the United States Government. Neither the United States Government nor any agency Thereof, nor any of their employees, makes any warranty, express or implied, or assumes any legal liability or responsibility for the accuracy, completeness, or usefulness of any information, apparatus, product, or process disclosed, or represents that its use would not infringe privately owned rights. Reference herein to any specific commercial product, process, or service by trade name, trademark, manufacturer, or otherwise does not necessarily constitute or imply its endorsement, recommendation, or favoring by the United States Government or any agency thereof. The views and opinions of authors expressed herein do not necessarily state or reflect those of the United States Government or any agency thereof. 


\section{DISCLAIMER}

Portions of this document may be illegible in electronic image products. Images are produced from the best available original document. 


\section{Printed in USA. Price: $\$ 2.75$ Available from the \\ Office of Technical Services \\ U. S. Department of Commerce \\ Washington 25, D. C.}

\section{LEGAL NOTICE}

This report was prepared as an account of Government sponsored work. Neither the United States, nor the Commission, nor any person acting on behalf of the Commission:

A. Makes any warranty or representation, expressed or implied, with respect to the accuracy, completeness, or usefulness of the information contained in this report, or that the use of any information, apparatus, method, or process disclosed in this report may not infringe privately owned rights; or

B. Assumes any liabilities with respect to the use of, or for damages resulting from the use of any information, apparatus, method, or process disclosed in this report.

As used in the above, "person acting on behalf of the Commission" includes any employee or contractor of the Commission, or employee of such contractor, to the extent that such employee or contractor of the Commission, or employee of such contractor prepares, disseminates, or provides access to, any information pursuant to his employment or contract with the Commission, or his employment with such contractor. 


\title{
IN-PILE LOOP CORROSION EXPERIMENTS WITH URANYL SULFATE SOLUTIONS AT 235 AND $250^{\circ} \mathrm{C}$
}
G. H. Jenks
J. E. Baker

Other Contributors
E. G. Bohlmann
A. R. Olsen
S. E. Bolt
M. L. Picklesimer
J. W. Brown
H. C. Savage
R. A. Lorenz
F. J. Walter
J. R. McWherter
S. H. Wheeler

DATE ISSUED

AUG 151963

\author{
OAK RIDGE NATIONAL LABORATORY \\ Ook Ridge, Tennessee \\ operated by \\ UNION CARBIDE CORPORATION \\ for the \\ U. S. ATOMIC ENERGY COMMISSION
}


THIS PAGE

\section{WAS INTENTIONALLY \\ LEFT BLANK}




\section{CONTENTS}

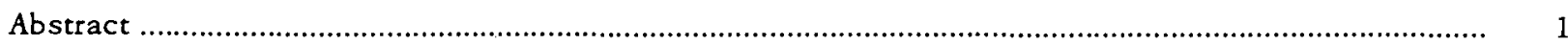

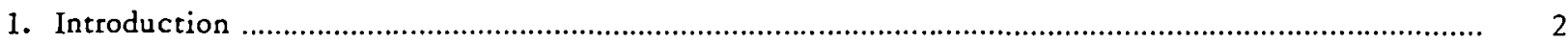

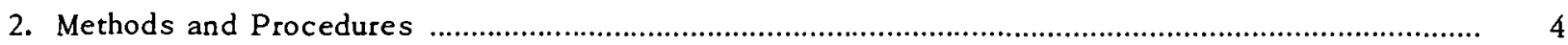

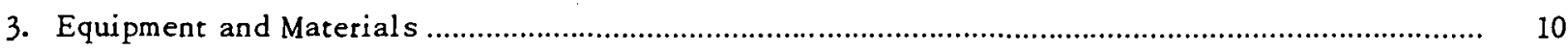

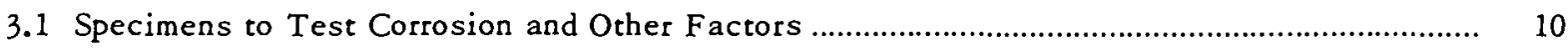

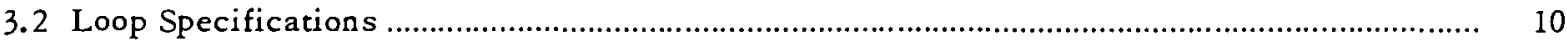

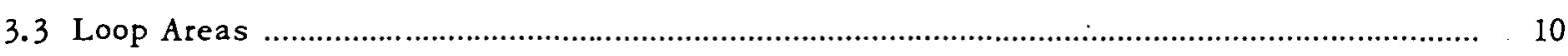

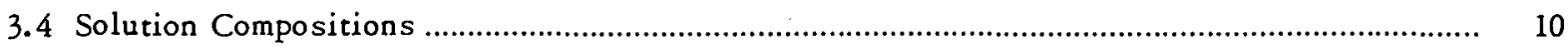

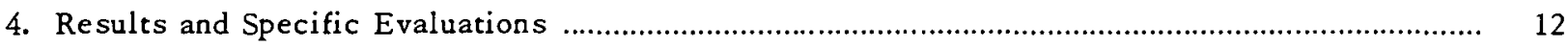

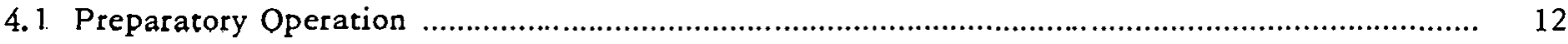

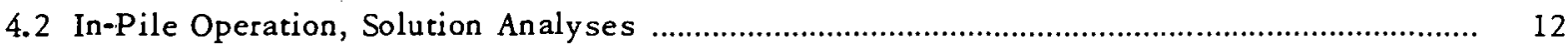

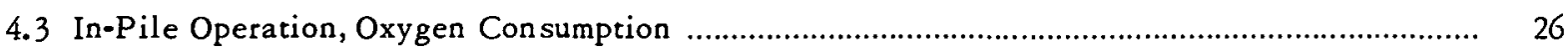

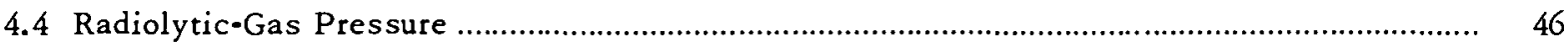

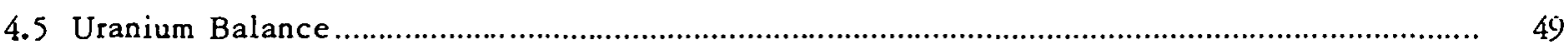

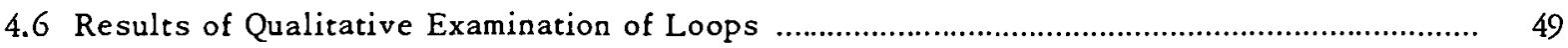

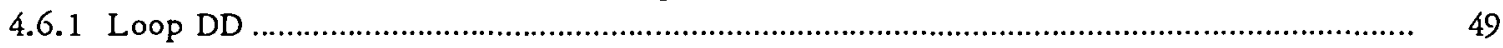

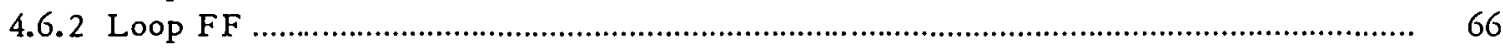

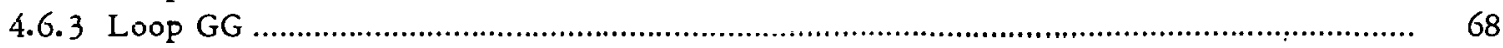

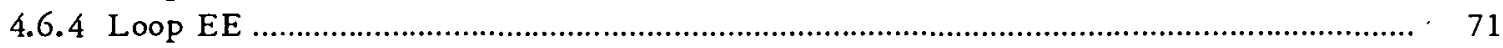

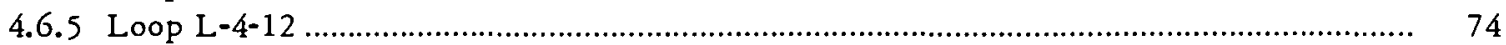

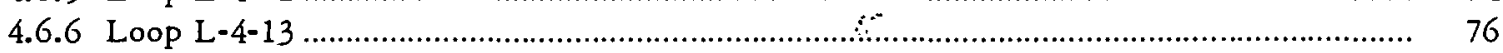

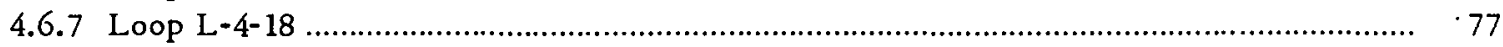

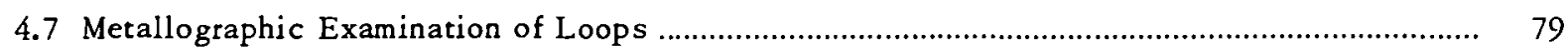

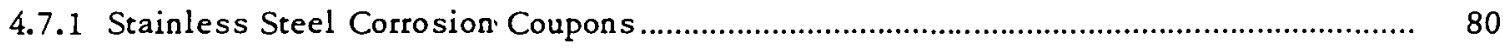

4.7.2 Zirconium and Zirconium-Alloy Corrosion Coupons ............................................. 85

4.7 .3 I'itanium-Alloy Corrnsion C.upons ................................................................ 88

4.7.4 Stress Corrosion Specimens ............................................................................... 88

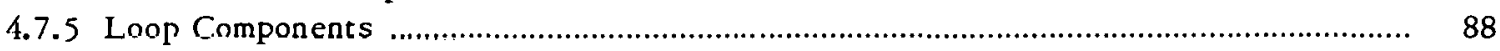

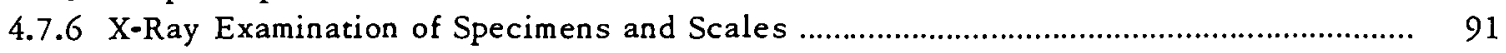

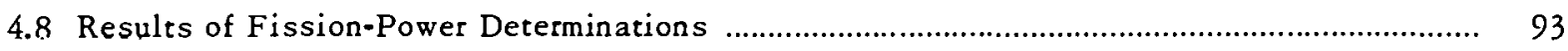

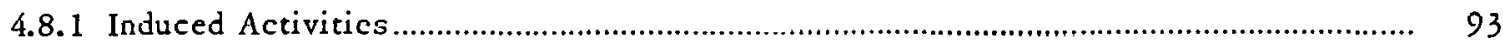

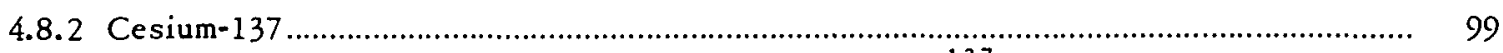

4.8.3 Comparison of Average Fission-Power Values from $\mathrm{Cs}^{137}$ and from

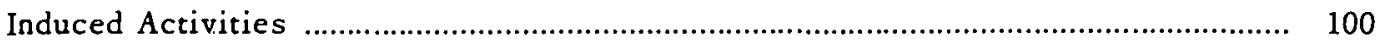

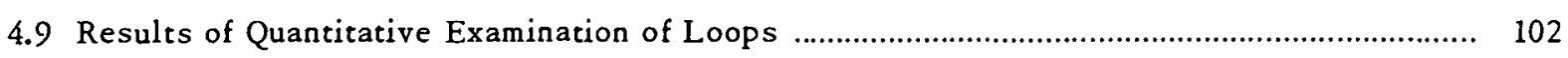

4.9.1 Analy ses of Scale from Low-Power Density Regions .............................................. 102

4.9.2 Analyses for Uranium on Steel Surfaces from High-Power Density Regions ................ 105

4.9 .3 Results of Specimen Weight Measurements .................................................... 106 


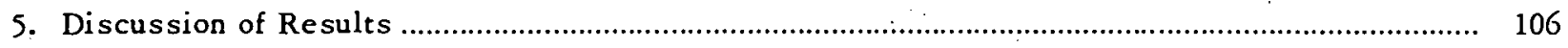

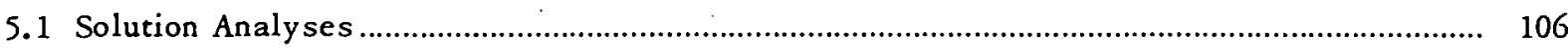

5.1.1 Charged Solutions, Nonradioactive Samples ........................................................ 129

5.1.2 Uranium, Copper, and Sulfate in Loop Solutions During Irradiations ........................... 133

5.1 .3 Free Acid in Solutions During Irradiation ............................................................. 136

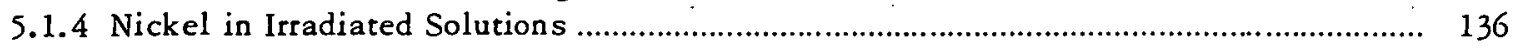

5.1.5 Other Constituents of Loop Solutions ........................................................................... 139

5.2 Corrosion of Type 347 Stainless Steel During In-Pile Exposure ........................................ 140

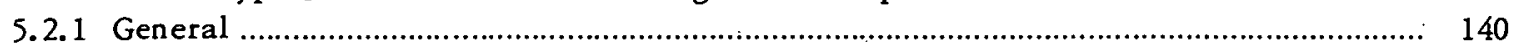

5.2.2 Effects of Solution Velocity on Core Specimen Corrosion ......................................... 141

5.2.3 Comparison Between Total Amounts of Steel Corrosion Determined from Oxygen Consumption and from Nickel Accumulation Data ......................................... 142

5.2.4 Correlations Between Solution Compositions and Rate of Oxygen Consumption by Steel ........................................................................................... 142

5.3 Corrosion of Zircaloy-2 and Crystal-Bar Zirconium ........................................................ 146

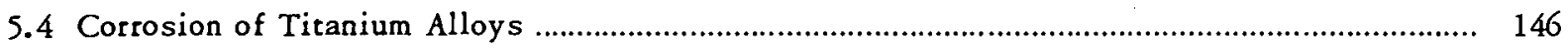




\title{
IN-PILE LOOP CORROSION EXPERIMENTS WITH URANYL SULFATE SOLUTIONS AT 235 AND $250^{\circ} \mathrm{C}$
}

\author{
G. H. Jenks \\ J. E. Baker
}

\begin{abstract}
In-pile loop experiments DD, EE, FF, GG, L-4-12, L-4-13, and L-4-18 were seven of a series designed to test the radiation corrosion of zirconium, titanium, and stainless steel alloys in $\mathrm{UO}_{2} \mathrm{SO}_{4}$ solutions under various conditions of radiation intensity, temperature, solution composition, and velocity of flow. Also investigated to a lesser extent were the effects of the in-pile exposure on impact and tensile properties of various structural materials, solution stability under irradiation, rate constants for recombination of radiolytic gas by copper in solution, and the general reliability of equipment operating under the test conditions.

Steel specimens exposed in the loop cores showed increases in corrosive attack over that expected out-of-radiation. The average rates of corrosion increased with power density in adjacent solution, but below certain power densities $(0.3$ to $4.2 \mathrm{w} / \mathrm{ml}$ in the various experiments) the average rate was not noticeably different from that occurring on in-line specimens, nor significantly different from that expected during out-of-pile exposures. These results, indicating that the effects of in-pile exposure on steel corrosion were confined to the core, were obtained from weight-change data, oxygen consumption rates, and measurements of nickel accumulation in solution, as well as from metallographic and visual examinations of specimens and components. Stainless steel corrosion rates probably changed considerably during the course of an experiment as indicated by the changes in the rate of oxygen consumption, varying by a factor of about 40 in one experiment and by a factor of 2 in another. No effect of stress or of galvanic coupling with other materials was noted in the corrosion behavior of stainless steel specimens located in the core and in-line positions. In one experiment a definite couple attack was noted between a 17-4 PH steel stress specimen and a $\mathrm{C}-130 \mathrm{AM}$ titanium-alloy specimen located in the loop pressurizer. In the $235^{\circ} \mathrm{C}$ experiment, type 430L stainless steel specimens were affected by exposure to fissioning solution to about the same extent as type 347 stainless steel. In a $250^{\circ} \mathrm{C}$ experiment, type $309 \mathrm{SCb}$ stainless steel exhibited about the same general relationship between power density and rate as type 347 stainless steel, but at a given power density the type 309 rates were greater than those for type 347 .

Data obtained in these and other experiments of the series indicate both adverse and beneficial effects on steel corrosion under exposure to fissioning uranyl sulfate solutions with increasing solution velocity. The experimental conditions under which one or the other of the effects predominates are unknown, but it is speculated that the beneficial effect may result from a reduction of sorbed uranium on the steel surfaces, and the adverse effect to result following damage to the protective film during irradiation.

It was concluded that the average rate of steel corrosion in the loop cores in the $250^{\circ} \mathrm{C}$ experiments was dependent on the concentration of excess $\mathrm{H}_{2} \mathrm{SO}_{4}$ and of $\mathrm{NiSO}_{4}$ in the loop solution, the rate decreasing with decreasing acid and with increasing $\mathrm{NiSO}_{4}$. The most likel y explanation for these effects is that the corrosion was influenced by the hydrogen ion concentration at the exposure temperature, and that the $\mathrm{NiSO}_{4}$ in solution tended to reduce this concentration through the formation of $\mathrm{HSO}_{4}^{-}$. This ion is known to be very stable at $250^{\circ} \mathrm{C}$.

Analyses of solution samples withdrawn periodically from the experiments indicated, on the average, no significant loss of uranium ur sulfate from solution. Loss of copper from solution ranging from 1 to $11 \%$ was indicated in most of the experiments.

Copper rate constants ar $250^{\circ} \mathrm{C}$, based on an activation energy of $22,000 \mathrm{kcal} / \mathrm{mole}$ for the copper activity, ranged from 2400 to 3200 liters $\mathrm{mole}^{-1} \mathrm{hr}^{-1}$ and are in reasonable agreement with those determined in out-of-pile tests. The constants in the experiments employing $\mathrm{D}_{2} \mathrm{O}$ solutions were below those measured or predicted for water solutions.
\end{abstract}




\begin{abstract}
Corrosion data for zirconium and titanium alloys obtained in these experiments are presented but not discussed, since they are in general agreement with other data for these materials which have been reported and extensively discussed el sewhere.
\end{abstract}

\title{
1. INTRODUCTION
}

Solutions of uranyl sulfate at temperatures in the neighborhood of 250 to $300^{\circ} \mathrm{C}$ and contained by or in contact with various structural materials such as zirconium, titanium, and stainless steel alloys have been of interest as possible fuel systems for aqueous homogeneous reactors. A series of 18 in-pile loop experiments has been carried out with the primary objective of testing the effects of reactor radiations on corrosion in these systems. Also investigated in some of the experiments were the effects of the in-pile exposure on impact and tensile properties of various structural materials, solution stability under irradiation, rate constants for recombination of radiolytic gas by copper sulfate in solution, and the general reliability of equipment operating under the test conditions.

The methods, equipment, and procedures employed in these experiments have been described in detail elsewhere. ${ }^{1}$ Each experiment has also been discussed or summarized in HRP quarterly progress reports. Results and conclusions were included; however, detailed reports of each experiment are planned, and some have been prepared and issued for several experiments. The present paper describes six of the eight early experiments which employed exposure temperatures of 250 and $280^{\circ} \mathrm{C}$ in the mainstream and pressurizer, respectively, $0.17 \mathrm{~m} \mathrm{UO}_{2} \mathrm{SO}_{4}$ solutions, and were exposed to reactor radiations in the LITR (HB-4 facility). (The other two experiments have been described in separate topical reports. ${ }^{2,3}$ ) This paper also includes a report of a similar experiment, $\mathrm{L}-4-18$, in which the exposure temperature was $235^{\circ} \mathrm{C}\left(265^{\circ} \mathrm{C}\right.$ in the pressurizer).

Some general information on the composition of the solutions employed and the materials tested in these experiments is set forth in Table 1 . The temperature was near the maximum which could be used with the available loop design. The $0.17 \mathrm{~m} \mathrm{UO}_{2} \mathrm{SO}_{4}$ solutions were selected for investigation because thiey had been extensively investigated out-of-pile and because the higher fission-powcr densities; in solution near specimens, which were achievable at this uranium concentration were considered desirable. (The fission-power densities in the $0.17 \mathrm{~m} \mathrm{UO}_{2} \mathrm{SO}_{4}$ solutions were probably near the maximum achievable for the given reactor facility and loop. ${ }^{4}$ ) The $\mathrm{CuSO}_{4}$ concentration of $0.03 \mathrm{~m}$ was selected to give controlably low radiolytic-gas pressures at the fission powers employed. In general, the other conditions in a

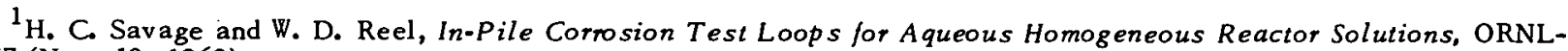
2977 (Nov. 10, 1960).

${ }^{2}$ J. E. Baker and G. H. Jenks, HRP Radiation Comosion Studies: In-Pile Loop L-4-8, ORNL-2042 (Aug. 8, 1956).

${ }^{3}$ J. R. McWherter and J. E. Baker, HRP Radiation Corrosion Studies: In-Pile Loop L-4-11, ORNL-2152 (June 11, 1958).

4. C. Noderer, In-Pile Test Loop and HB-6 Bomb Power Density, ORNL CF-54-9-238 (Sept. 21, 1954).
} 
Table 1. Test Solution Compositions and Operating Time Data for Low-Temperature Loop Experiments

\begin{tabular}{|c|c|c|c|c|c|c|c|c|c|c|c|c|c|c|c|}
\hline \multirow{2}{*}{$\begin{array}{l}\text { Experiment } \\
\text { Number }\end{array}$} & \multirow{2}{*}{$\begin{array}{l}\text { Dace Exposed } \\
\text { in Reactor }\end{array}$} & \multicolumn{6}{|c|}{$\begin{array}{l}\text { Initial and Final Solution Composition } \\
\qquad(M \text { at STP })^{a}\end{array}$} & \multicolumn{5}{|c|}{$\begin{array}{c}\text { Nakeu? Solution Composition } \\
(M \text { at STP })^{a}\end{array}$} & \multicolumn{2}{|c|}{$\begin{array}{l}\text { Time at Temperature } \\
\text { with } \mathrm{UO}_{2} \mathrm{SO}_{4} \text { Solution } \\
(\mathrm{hr})\end{array}$} & \multirow{2}{*}{$\begin{array}{c}\text { Radiation } \\
\text { Exposure Time } \\
\text { (3-Mwhr } \\
\text { LITR Energy) }\end{array}$} \\
\hline & & $\mathrm{UO}_{2} \mathrm{SO}_{4}$ & $\mathrm{CuSO}_{4}$ & $\mathrm{Ni}$ & $\mathrm{Cr}$ & $\begin{array}{l}\text { Excess } \\
\mathrm{H}_{2} \mathrm{SO}_{4}\end{array}$ & $\mathrm{pH}^{b}$ & $\mathrm{UO}_{2} \mathrm{SO}_{4}$ & $\mathrm{CuSO}_{4}$ & $\begin{array}{l}\text { Excess } \\
\mathrm{H}_{2} \mathrm{SO}_{4}\end{array}$ & $\begin{array}{l}\mathrm{Cr} \text { as } \\
\mathrm{C}: \mathrm{O}_{3}\end{array}$ & $\mathrm{pH}$ & Natural & Enriched & \\
\hline $\mathrm{DD}$ & $\begin{array}{l}\text { In } 10-8 \cdot 54 \\
\text { Ost } 10-26-54\end{array}$ & $\begin{array}{l}0.165 \\
0.148\end{array}$ & $\begin{array}{l}0.130 \\
0.028\end{array}$ & $\begin{array}{c}0 \\
0.008\end{array}$ & $\begin{array}{l}0.002\left(\mathrm{CrO}_{3}\right) \\
0.006\end{array}$ & $\begin{array}{l}0.016^{c} \\
0^{c}\end{array}$ & $\begin{array}{l}1.8 \\
2.5\end{array}$ & & & $\mathrm{H}_{2} \mathrm{O}$ & & & 85 & 465 & 280 \\
\hline $\mathrm{FF}$ & $\begin{array}{l}\text { Ir. } 12 \cdot 29-54 \\
\text { Out } 1 \cdot 26-55\end{array}$ & $\begin{array}{l}0.170 \\
0.167\end{array}$ & $\begin{array}{l}0.028 \\
0.030\end{array}$ & $\begin{array}{c}0 \\
0.015\end{array}$ & & $\begin{array}{l}0.050^{c} \\
0.015^{c}\end{array}$ & $\begin{array}{l}1.3 \\
1.9\end{array}$ & 0.170 & 0.128 & $0.050^{e}$ & & 1.3 & 124 & 692 & 467 \\
\hline GG & $\begin{array}{l}\text { Ir. } 2 \cdot 20-55 \\
\text { Out } 4-6-55\end{array}$ & $\begin{array}{l}0.169 \\
0.170\end{array}$ & $\begin{array}{l}0.027 \\
0.028\end{array}$ & $\begin{array}{c}0 \\
0.031\end{array}$ & $\underset{0}{0.006}\left(\mathrm{CrO}_{3}\right)$ & $\begin{array}{l}0.056^{c} \\
0.023^{c}\end{array}$ & $\begin{array}{l}1.25 \\
1.7\end{array}$ & 0.169 & 0.128 & $0.056^{c}$ & 0.009 & 1.25 & 105 & 1064 & 897 \\
\hline $\mathrm{EE}$ & $\begin{array}{l}\text { In } 5 \cdot 1-55 \\
\text { Cut } 5 \cdot 29 \cdot 55\end{array}$ & $\begin{array}{l}0.164 \\
0.163\end{array}$ & $\begin{array}{l}0.028 \\
0.027\end{array}$ & $\begin{array}{c}0 \\
0.007\end{array}$ & $\begin{array}{l}0 \\
0\end{array}$ & $\begin{array}{l}0.020^{c} \\
0.012^{c}\end{array}$ & $\begin{array}{l}1.7 \\
2.0\end{array}$ & 0.163 & 0.026 & $0.050^{c}$ & & 1.3 & 127 & 630 & 537 \\
\hline \multirow[t]{2}{*}{$L-4-1 ?$} & $\begin{array}{l}\text { In } 1-19-56 \\
\text { Cut } 2-21-56\end{array}$ & $\begin{array}{l}0.170 \\
0.170\end{array}$ & $\begin{array}{l}0.032 \\
0.032\end{array}$ & $\begin{array}{c}0 \\
0.007\end{array}$ & $\begin{array}{c}0 \\
0.001\end{array}$ & $\begin{array}{l}0.050^{c} \\
0.032^{c}\end{array}$ & $\begin{array}{l}1.3 \\
1.55\end{array}$ & 0.170 & 0.032 & $0.050^{c}$ & & 1.3 & 153 & 719 & 1462 \\
\hline & $\begin{array}{l}\text { In } 2-24-56 \\
\text { Cut } 4-16-56\end{array}$ & $\begin{array}{l}0.167 \\
0.177\end{array}$ & $\begin{array}{l}0.027 \\
0.029\end{array}$ & $\begin{array}{c}0 \\
0.014\end{array}$ & $\begin{array}{c}0 \\
0.002\end{array}$ & $\begin{array}{l}0.050^{c} \\
0.014^{c}\end{array}$ & $\begin{array}{l}1.3 \\
1.85\end{array}$ & 0.167 & 0.027 & $0.050^{c}$ & & 1.3 & & 1301 & \\
\hline $\mathrm{L} \cdot 4 \cdot 13^{a}$ & $\begin{array}{l}\text { In } 9.21 .56 \\
\text { Out } 11-6-56\end{array}$ & $\begin{array}{l}0.176 \\
0.179\end{array}$ & $\begin{array}{l}0.034 \\
0.029\end{array}$ & $\begin{array}{c}(9 \mathrm{ppm}) \\
0.010\end{array}$ & $\begin{array}{c}<0.0005 \\
0.002\end{array}$ & $\begin{array}{l}0.020^{d} \\
0.020^{d}\end{array}$ & $\begin{array}{l}1.40^{e} \\
1.65^{e}\end{array}$ & 0.176 & 0.031 & $0.044^{d}$ & & $1.05^{P}$ & 170 & 1042 & 787 \\
\hline$L-4-13^{a}$ & $\begin{array}{l}\text { In } 6.19-57 \\
\text { Out } 7-30.57\end{array}$ & $\begin{array}{l}0.170 \\
0.176\end{array}$ & $\begin{array}{l}0.068 \\
0.072\end{array}$ & $\begin{array}{c}0 \\
0.003\end{array}$ & $\begin{array}{r}<0.0005 \\
0.0005\end{array}$ & $\begin{array}{l}0.019^{d} \\
0.013^{d}\end{array}$ & $\begin{array}{l}1.50^{e} \\
1.75^{e}\end{array}$ & 0.170 & 0.063 & & & $1.40^{e}$ & 161 & 860 & 642 \\
\hline
\end{tabular}

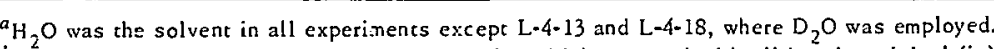

${ }^{6} \mathrm{No}$ correction to $\mathrm{pH}$ readings for sample dilution which occur:ed with all but the original (in) solutions.

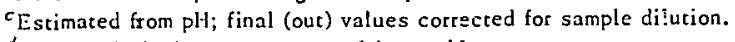

${ }^{d}{ }_{F}$ rom analyrical measurements of free acid.

$e_{\mathrm{V} a l u e s}$ for $\mathrm{D}_{2} \mathrm{O}$ solutions obrained with $\mathrm{pH}$ meter calibrated with $\mathrm{H}_{2} \mathrm{O}$ solutions (nor used in estimating acidity). 
given experiment such as $\mathrm{H}_{2} \mathrm{SO}_{4}$ concentrations, $\mathrm{H}_{2} \mathrm{O}$ or $\mathrm{D}_{2} \mathrm{O}$ solvent, specimen arrangements, etc., were selected in attempts to elucidate factors which appeared important at the time and/or to promote solution stability.

\section{METHODS AND PROCEDURES}

A given overall experiment included: (1) preparing the loop for operation and proving its satisfactory performance in out-of-pile mockup operation, (2) exposing and operating the loop in Hole HB-4 of the LITR, and (3) dismantling the loop and examining corrosion specimens and other portions of the loop for evidence of corrosive attack.

The preparation, testing, and in-pile operation of a loop have been described in detail elsewhere. ${ }^{1} \mathrm{~A}$ listing of the different types of examinations, operations, and mea surements for the results included in this report and the objectives of these are given below.

1. Sampling and chemical analyses of loop solutions during out-of-pile preparatory operations. Also, measurements of oxygen consumption during high-temperature operations with some of the solutions. The objective was to determine a rough value of the stainless steel corrosion rate in test solution out-of-pile and thus establish that no materials of low corrosion resistance were included in the loop. The out-ofpile thermal stability of the. different solutions was not in question, and no attempt was made to sample and analyze solutions with sufficient accuracy to establish solution stability independently.

2. Sampling of loop solution at regular intervals during in-pile operation, and analyses for various constituents. (Usually the sample was taken with the reactor at power. Sample volumes were usually about $2 \mathrm{ml}$. The LITR operation and sampling schedule are shown in Figs. 1-7.) The solution analyses were carried out primarily to aid in evaluating (1) the stability of the solution during in-pile operations, (2) the corrosion behavior of stainless steel, (3) the solubilities of corrosion products, and (4) the fission power generated in solution ( $\mathrm{Cs}^{137}$ analyses). The sampling procedure was such that a dilution of the sample by wash water took place in the sample lines. Prior to experiment GG, the amount of this dilution was uncertain. For GG and subsequent experiments, the dilution was determined by analyzing for $\mathrm{Li}_{2} \mathrm{SO}_{4}$ tracer added to the wash water.

3. Determinations of pressures of excess oxygen and of radiolytic gases in the pressurizer. Accurate measurements of temperature and pressure in a loop pressurizer were made at frequent intervals during a run, and the partial pressure of permanent gases was determined from the results. When the reactor was at power, the gases were radiolytic hydrogen and oxygen and excess oxygen. The radiolytic-gas pressures were determin ed from pressure changes at reactor startup and shutdown and, except for those periods, usually did not change rapidly with time. It was thereby possible to follow trends of oxygen consumption during reactor operation. Precise measurements of the oxygen pressures were made during reactor-down periods when the radiolytic-gas pressure was negligible. When the excess oxygen partial pressure was in the range of about 30 to $50 \mathrm{psi}$, the reactor was shut down and oxygen was added to bring the pressure to some higher value ( 75 to $125 \mathrm{psi}$ ).

Oxygen consumption measurements were made to follow the overall corrosion behavior during radiation exposure and to determine the total amounts of oxidation at given times. As will be shown and discussed, 


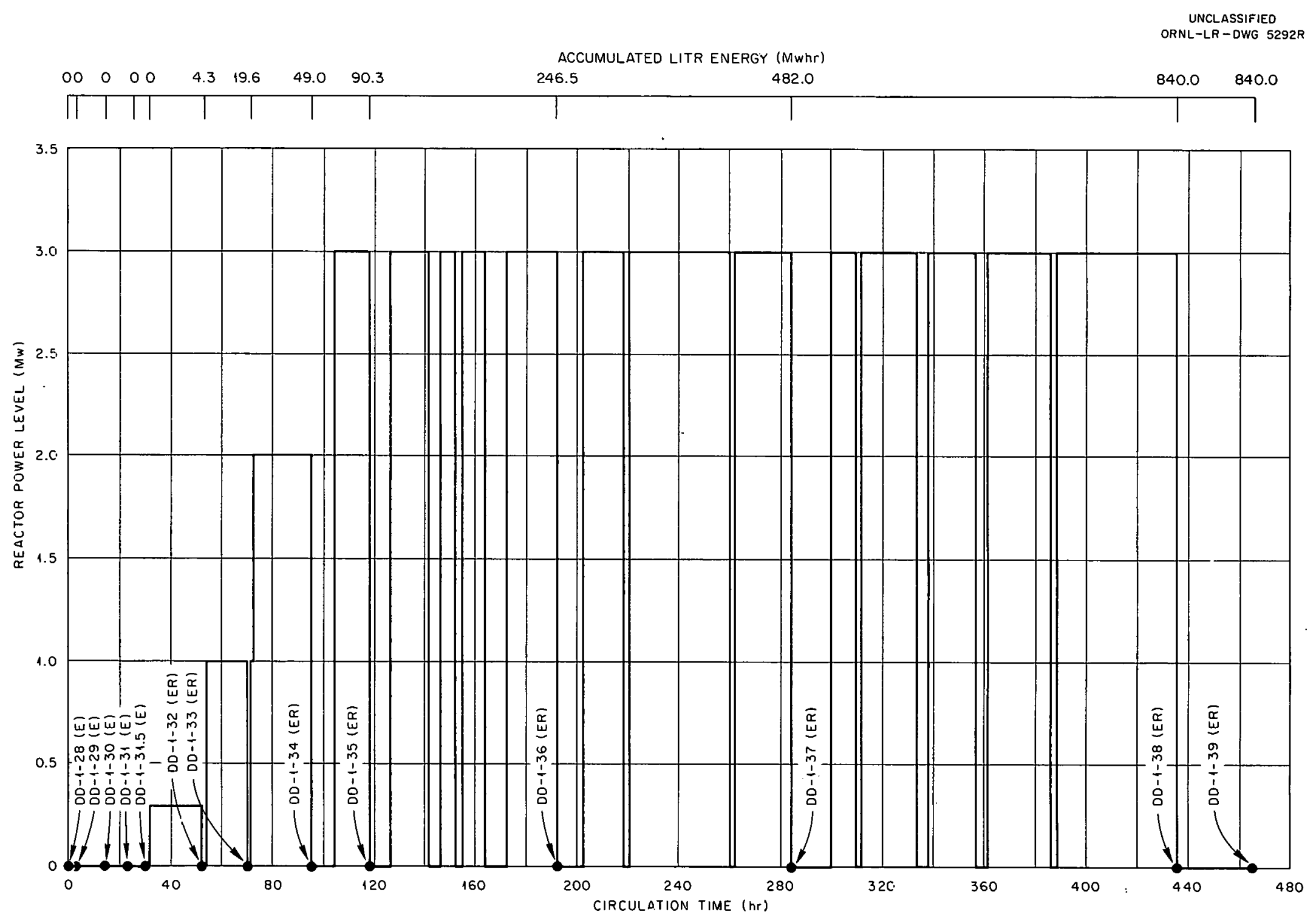

Fig. 1. LITR Operation and Loop Sampling Schedule, Loop DD. 


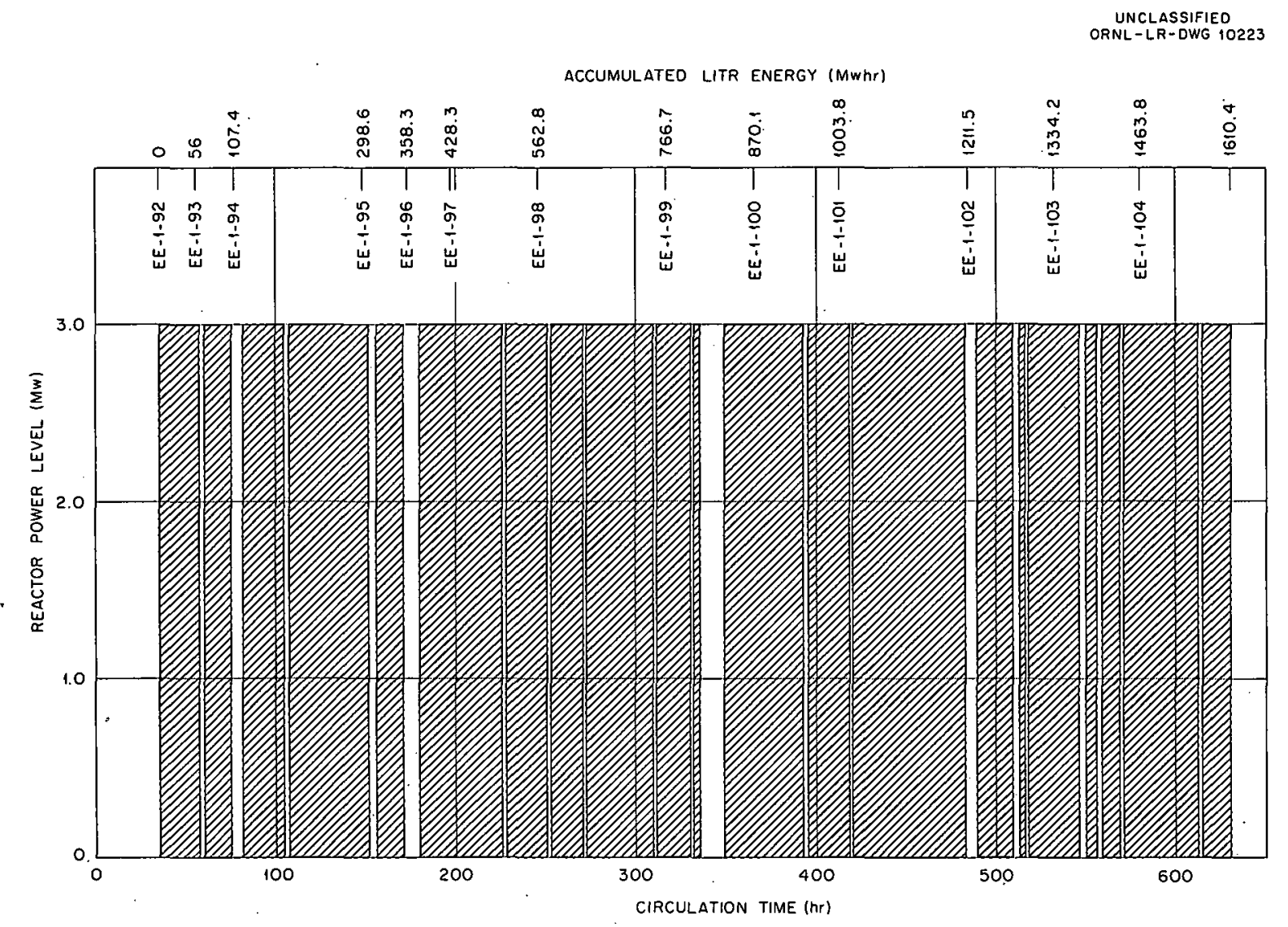

Fig. 2. LITR Operation and Loop Sampling Schedule, Loop EE.

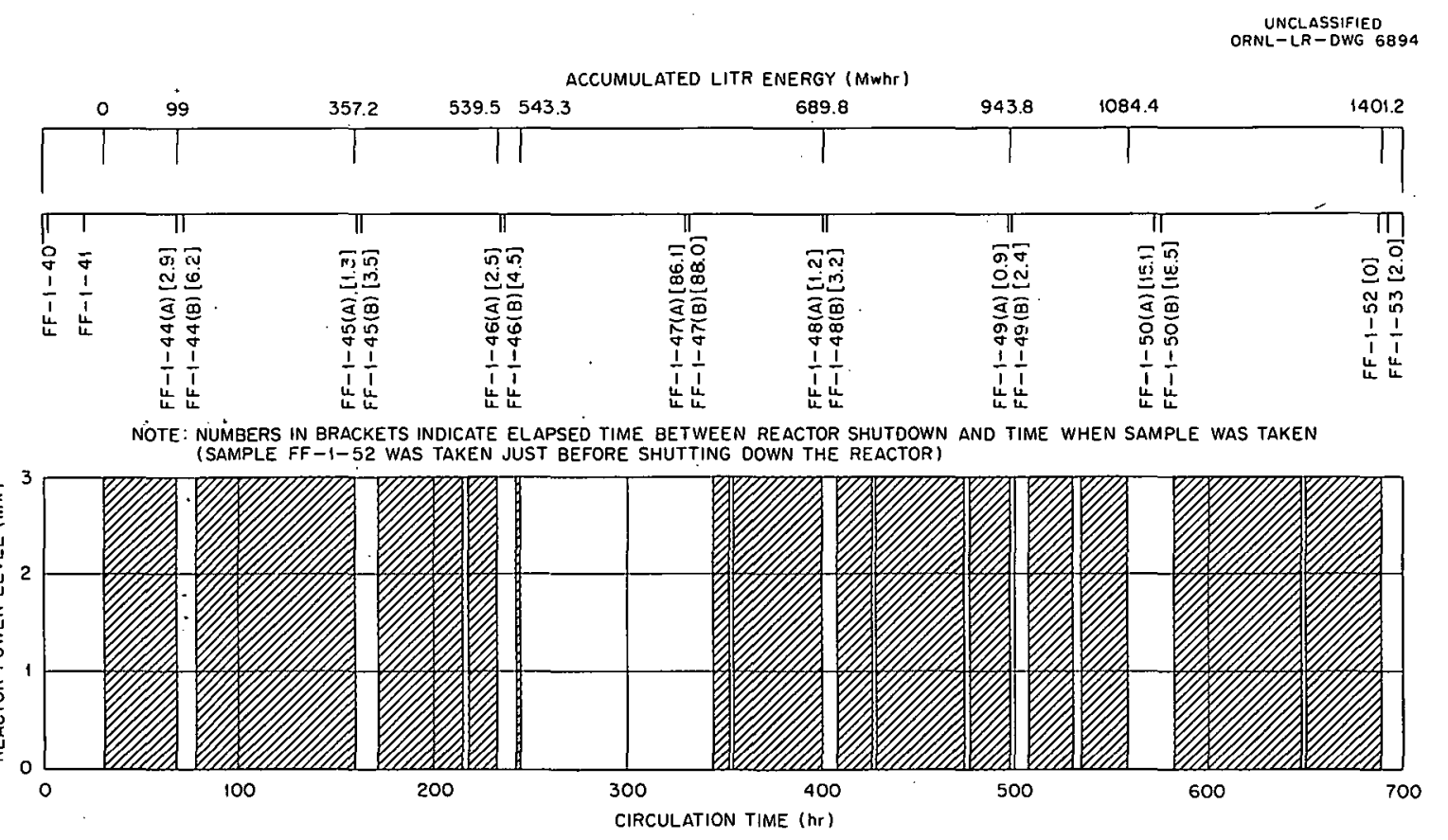

Fig. 3. LITR Operation and Loop Sampling Schedule, Loop FF. 
UNCLASSIFIED

ORNL-LR-DWG 8443R

ACCUMULATED LITR ENERGY (Mwhr)

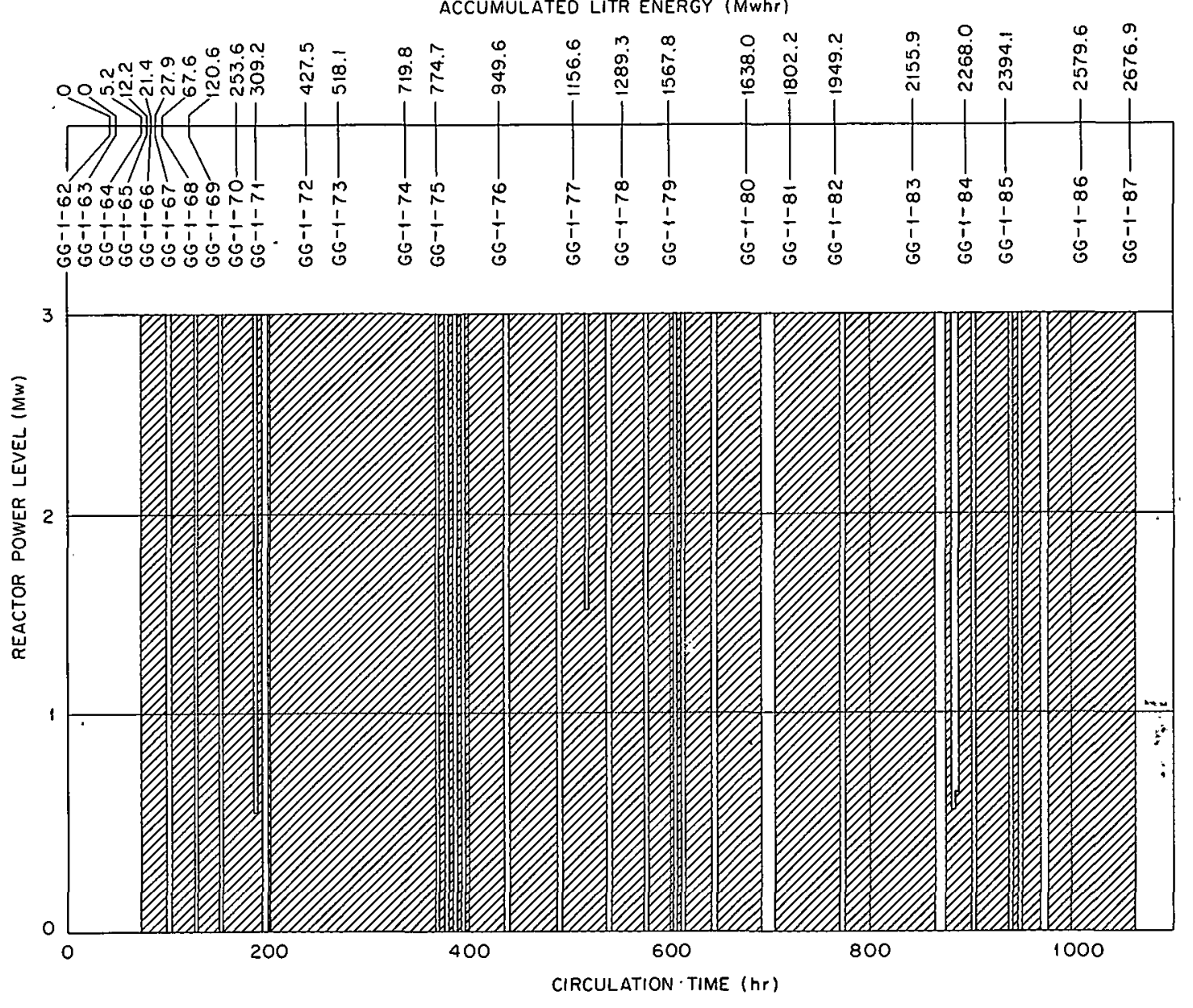

Fig. 4. LITR Operation and Loop Sampling Schedule, Loop GG.

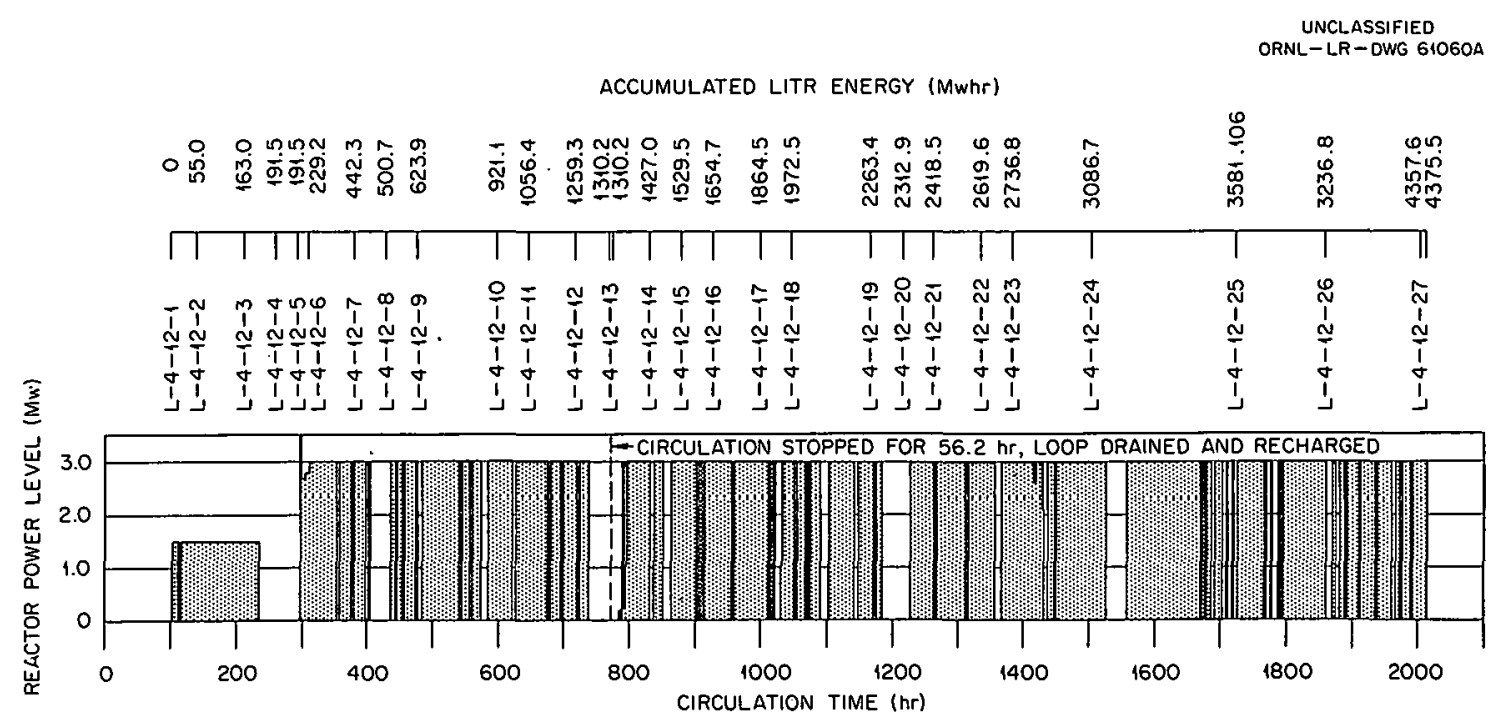

Fig. 5. LITR Operation and Loop Sompling Schedule, Loop L-4.12. 


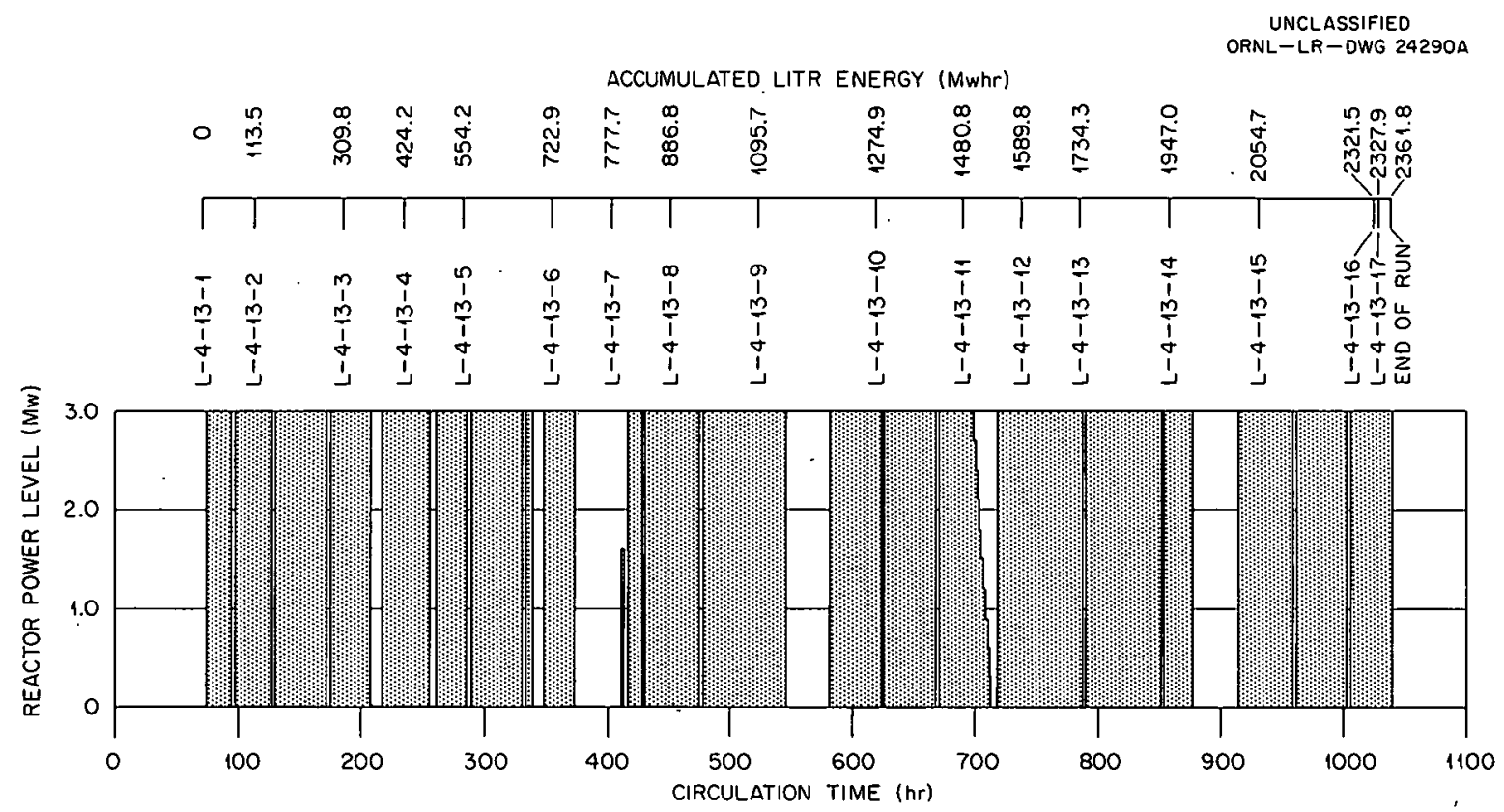

Fig. 6. LITR Operation and Loop Sampling Schedule, Loop L-4-13.

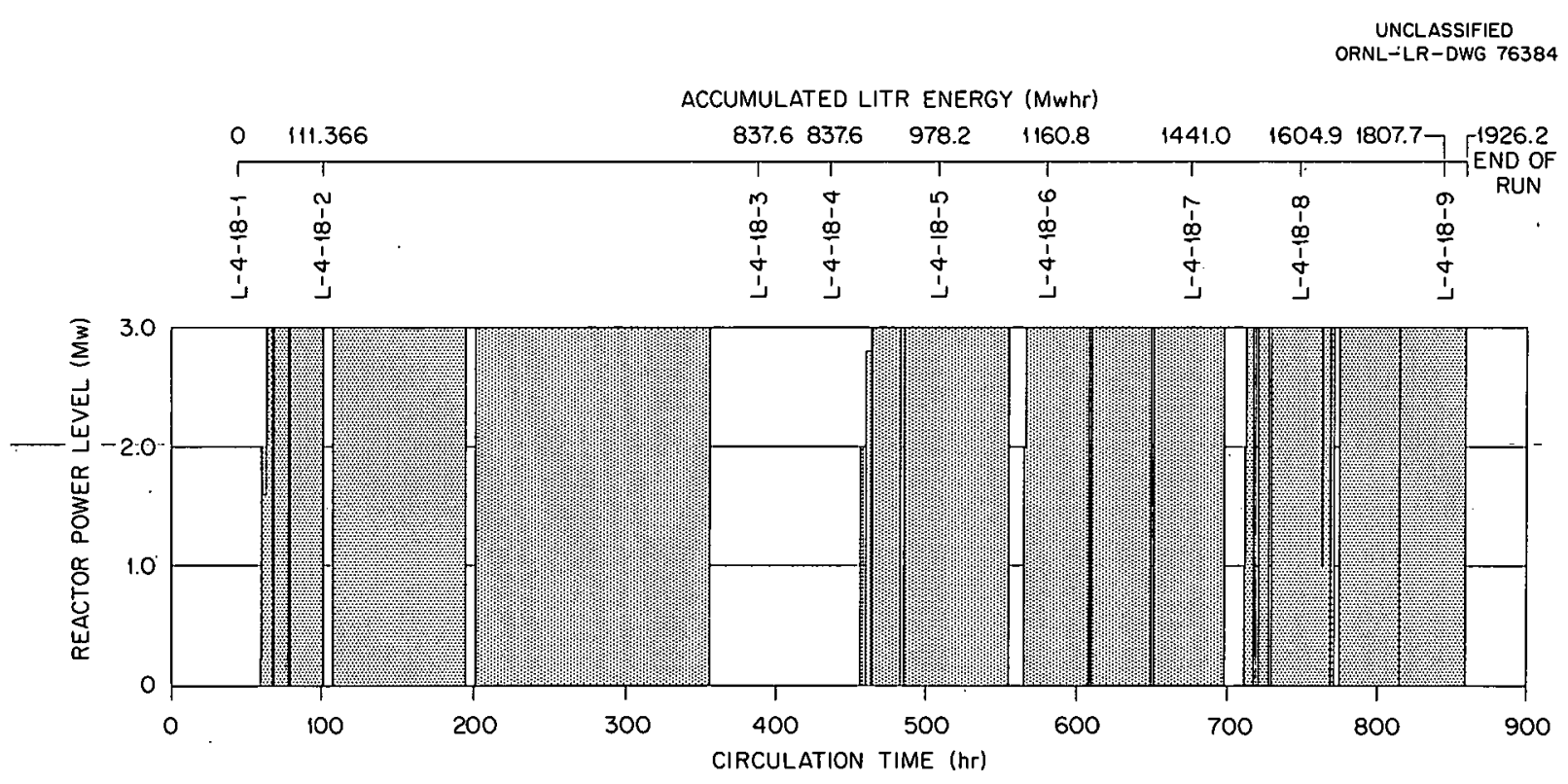

Fig. 7. LITR Operation and Loop Sompling Sehedule, Loop L-4-18. 
the oxygen results enabled an evaluation of the total amounts and other facets of the steel corrosion in a loop, since the amounts going to other materials, primarily zirconium alloys, could be evaluated from weight-change data, and it is believed that these other materials corroded approximately linearly with radiation time. 5 Furthermore, the consumption of oxygen by the other materials was, generally, much less than the consumption by steel.

Radiolytic pressure measurements were carried out as part of the program to define and control experimental conditions in the loop. The results of these measurements were used to calculate $\mathrm{H}_{2}$ pressures in the mainstream and the rate constant for recombination of radiolytic gas by the copper in solution in a given experiment.

4. Sampling of solution in weigh tank (solution dump tank). After an experiment was completed, the solution and rinses were collected in the weigh tank. Several samples of solution were taken and submitted for chemical analyses. These analyses were made as part of the effort to evaluate the balance between uranium charged to and recovered from the loop.

5. Qualitative inspection of loop after radiation exposure. Following completion of the radiation exposure, the drained and rinsed loop was opened in a remote examination facility, ${ }^{6}$ and various portions were removed and inspected visually. Corrosion specimens were examined before and after defilming. The objective was to provide information on the corrosion behavior of various components and on the types and locations of corrosion scales.

6. Determination of specimen weight losses resulting from corrosion. Specimens were usually weighed as removed from the loop, subjected to cathodic defilming to remove corrosion-product oxide, and then reweighed. The objective was to determine the average corrosion penetration of specimens from weightchange data. The defilming operation was usually effective in removing scale from steel surfaces, but was not very effective with zirconium or titanium alloys. However, the core specimens, especially those at the highest power densities, were nearly free of heavy scales, and it is assumed that the weight of oxide retained on core specimens was negligible compared with the actual loss in weight of a specimen. As will be discussed later, this assumption is probably not valid for some of the titanium specimens which exhibited only very small differences between as-installed and as-defilmed weights. Specimens from locations outside the core generally retained some film after cathodic defilming.

7. Determination of thermal-neutron fluxes adjacent to core specimens. The neutron flux adjacent to stainless steel and to zirconium-alloy specimens was determined from comparisons berween the amounts of induced radioactivities in the specimens $\left(\mathrm{Cr}^{51}\right.$ in stainless steel and $\mathrm{Zr}^{95}$ and $\mathrm{Nb}^{95}$ in zirconium alloys) and those in control specimens irradiated along with a cobalt monitor in the LITR (loops L-4-12, L-4-13, and L-4-18) or the ORNL Graphite Reactor (loops DD, FF, GG, and EE). The loop specimens were pickled before measurement to remove fission-product activity.

${ }^{5}$ G. H. J enks, Review and Correlation of In-Pile Zircaloy-2 Corrosion Data and a Model for the E/fect of Irradiation, ORNL-3039 (July 1961).

${ }^{6}$ E. G. Bohlmann, "Integrity of Metals in Homogeneous Reactor Media," p 208 in Fluid Fuel Reactors (ed. by J. A. Lane et al.), Pt. 1, Addison-Wesley, Reading, Mass., 1958. 
These flux measurements were performed in order to evaluate the fission-power density in solution adjacent to core specimens. Results obtained in various loops have indicated that the flux values obtained with zirconium-alloy specimens are more reliable than those obtained with stainless steel. However, some of the early loops had more specimens of stainless steel than of zirconium alloys, and, for some of these experiments, it was assumed in the past. that the stainless steel flux values were more reliable. No change will be made in the previous treatments of these data, since the conclusions drawn from these results would not be altered by use of the zirconium-alloy flux results.

8. Metallographic examination of specimens and portions of loops. Some of the parts cut from loops as well as some corrosion specimens were submitted for metallographic examination for types and amounts of corrosion attack at surfaces and for measurements of the thickness of the specimens and corrosion scales. The metallographic examinations were performed to aid in the evaluation of the corrosion behavior of various materials and the location of corrosion scales.

\section{EQUIPMENT AND MATERIALS}

\subsection{Specimens to Test Corrosion and Other Factors}

The numbers and types of corrosion and mechanical-property specimens employed in the different loops are shown in Table 2. Compositions of some of the specimen materials are given in Table 3 . Nominal com positions were assumed for materials not shown.

Abbreviations used in referring to different types of specimens are the following: $\mathrm{CC}$, core channel; CA, core low velocity; LC, in-line channel; LA, in-line low velocity; PV, pressurizer vaporspace; and PL, pressurizer liquid space.

\subsection{Loop Specificotions}

Specifications for each loop, including volumes and materials of construction of pump and specimen holders, are listed in Table 4.

\subsection{Loop Areas}

Internal surface areas of each loop are listed in Table 5. Specimen and holder areas are included in Tables 36-42.

\subsection{Solution Compositions}

The compositions of the uranyl sulfate test solutions charged to and recovered from the loops are listed in Table 1. The compositions of the solutions used to replace those removed in sampling are also listed. In some cases no free-acid analyses were made, and the acid concentrations were determined from $\mathrm{pH}$ measurements as indicated in Table 1. As discussed later (Sec 5.1.1), these acid values are considered more nearly correct than the values assumed in previous reports of these experiments. 
Table 2. Corrosion Specimens Exposed in Loop Experiments

\begin{tabular}{|c|c|c|c|c|c|c|c|c|c|c|c|c|}
\hline \multirow[b]{2}{*}{ Experiment and Material } & \multirow[b]{2}{*}{$\begin{array}{l}\text { Stock }^{a} \\
\text { Item Number }\end{array}$} & \multicolumn{6}{|c|}{ Core } & \multicolumn{4}{|c|}{ In-Line } & \multirow{2}{*}{ 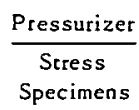 } \\
\hline & & $\begin{array}{l}\text { Channel } \\
\text { Coupons }\end{array}$ & $\begin{array}{l}\text { Annulus } \\
\text { Coupons }\end{array}$ & $\begin{array}{l}\text { Impact } \\
\text { Specimens }\end{array}$ & $\begin{array}{c}\text { Tensile } \\
\text { Specimens }\end{array}$ & $\begin{array}{c}\text { Stress } \\
\text { Specimens }\end{array}$ & $\begin{array}{l}\text { Rod-Type } \\
\text { Coupons }\end{array}$ & $\begin{array}{l}\text { Channel } \\
\text { Coupons }\end{array}$ & $\begin{array}{l}\text { Annulus } \\
\text { Coupons }\end{array}$ & $\begin{array}{c}\text { Impact } \\
\text { Specimens }\end{array}$ & $\begin{array}{c}\text { Stress } \\
\text { Specimens }\end{array}$ & \\
\hline \multicolumn{13}{|l|}{$\mathrm{DD}$} \\
\hline $\begin{array}{l}\text { Type } 347 \text { Stairless Steel } \\
\text { Zircaloy-2 }\end{array}$ & 304 or 1149 & 12 & & 8 & & & & 12 & & & & \\
\hline \multicolumn{13}{|l|}{$\mathrm{EE}$} \\
\hline $\begin{array}{l}\text { Type } 347 \text { Stainless Steel } \\
\text { Zircaloy-2 } \\
\text { Titanium-55A }\end{array}$ & $\begin{array}{c}1149 \\
\text { HRT plate No. } 8\end{array}$ & $\begin{array}{l}8 \\
8 \\
8\end{array}$ & & & & $\begin{array}{l}4 \\
4 \\
4\end{array}$ & $\begin{array}{l}12 \\
12 \\
12\end{array}$ & $\begin{array}{l}8 \\
8 \\
8\end{array}$ & & & & \\
\hline \multicolumn{13}{|l|}{$\mathrm{FF}$} \\
\hline Zirca:oy-2 & 1157 & 12 & & 8 & & & & 12 & & & & \\
\hline \multicolumn{13}{|l|}{ GG } \\
\hline Zircaloy=2 & 1157 & 12 & & 8 & & & & 12 & & & & \\
\hline \multicolumn{13}{|l|}{$L \cdot 4-12$} \\
\hline Type 347 Stainless Stẹel & 1146 & 8 & & & & & & 8 & & . & & \\
\hline Type 17.4 PH Stainless Steel & 376 & & & & & & & & & & & 4 \\
\hline Zircaloy-2 & 1157 & 8 & & 3 & & & & 8 & & 2 & & \\
\hline $\begin{array}{l}\text { Titanium-55A } \\
\text { Titanium RC-A-40 }\end{array}$ & 1165 & 8 & & 3 & & & & 8 & & 2 & & \\
\hline Titanium-6Al-4V & 1192 & & & & & 4 & & & & & 4 & 6 \\
\hline Titanium-C-13C-AM & 1175 & & & & & & & & & & 4 & . 6 \\
\hline $\begin{array}{l}\text { Titanium RC-70 } \\
\text { Titanium } 75-A\end{array}$ & & & & . & & & & & & & & \\
\hline \multicolumn{13}{|l|}{$L-4 \cdot 13$} \\
\hline Type 347 Stainless Steel & 1149 & 8 & & & & & & 8 & & & & \\
\hline Type 309SCb Stainless Steel & 1178 & 8 & & & & & & 8 & & & & \\
\hline Crystal-bar zirconium & $1591-8$ & 8 & & & & & & 8 & & & & \\
\hline $\mathrm{Zr}-20 \mathrm{Nb}$ & & & & 3 & & & & & & 3 & & \\
\hline $\begin{array}{l}\mathrm{Zr}-3 \mathrm{a} \\
\text { Tiranium-A40 }\end{array}$ & WAPD heat $5 Z-93$ & & & 3 & 1 & & & & & 3 & & \\
\hline \multirow{2}{*}{\multicolumn{13}{|c|}{$L \cdot 4 \cdot 18$}} \\
\hline $\begin{array}{l}\text { L·4-18 } \\
\text { Type } 347 \text { Stainless Steel }\end{array}$ & 1149 & 8 & 7 & & & & & 8 & & & & \\
\hline Type $430 \mathrm{~L}$ Stainless Steel & 1149 & 8 & 8 & & & & & 8 & $\begin{array}{l}7 \\
8\end{array}$ & & & \\
\hline Zircaloy-2 & 354 and 1157 & 8 & 4 & & & 2 & & 8 & 4 & & 2 & \\
\hline $\mathrm{Zr}-15 \mathrm{Nb}$ & Zr 84 & & 4 & & & & & & 4. & & & \\
\hline Titanilum $55 \mathrm{~A}$ & 1165 & & 3 & & & & & & 3 & & & \\
\hline Titanium-3Al & Heat 22657 & & 4 & & & & & & 4 & & & \\
\hline
\end{tabular}

${ }^{a}$ Available composition data given in Table 3. 
Table 3. Alloy Compositions

\begin{tabular}{|c|c|c|c|c|c|c|c|c|}
\hline \multirow{4}{*}{ Element } & \multicolumn{8}{|c|}{ Analyses (\%) } \\
\hline & \multicolumn{3}{|c|}{ Zircaloy-2 } & \multirow{2}{*}{\multicolumn{4}{|c|}{ Type 347 Stainless Steel }} & \multirow{3}{*}{$\begin{array}{c}\begin{array}{c}\text { Crystal-Bar } \\
\text { Zirconium }\end{array} \\
1591-8\end{array}$} \\
\hline & \multirow{2}{*}{$\begin{array}{c}\text { HRT Plate } \\
\text { No. } 8\end{array}$} & \multirow[b]{2}{*}{354} & \multirow[b]{2}{*}{1157} & & & & & \\
\hline & & & & 1146 & 1149 & 304 & HRT Steel $^{a}$ & \\
\hline Sn & 1.43 & 1.33 & 1.5 & & & & & $<0.05$ \\
\hline $\mathrm{Fe}$ & 0.12 & 0.108 & 0.5 & 69.6 & 69.2 & & 65.5 & 0.5 \\
\hline $\mathrm{Cr}_{\mathrm{r}}$ & 0.075 & 0.052 & 0.2 & 17.9 & 17.8 & 19.11 & 18.5 & $<0.05$ \\
\hline $\mathrm{Ni}$ & 0.04 & 0.038 & 0.1 & 10.2 & 10.2 & 9.86 & 12.5 & $<0.05$ \\
\hline C & 0.05 & & & & & & & \\
\hline $\mathrm{H}_{2}$ & $0.004-0.0055$ & & & & & & & \\
\hline $\mathrm{N}_{2}$ & 0.0060 & & & & & & & \\
\hline $\mathrm{C}$ & & & & 0.041 & 0.043 & 0.058 & & \\
\hline Mn & & & & 1.40 & 1.43 & 1.15 & 1.8 & \\
\hline $\mathbf{P}$ & & & & & & 0.020 & & \\
\hline $\mathrm{S}$ & & & & & & 0.027 & & \\
\hline $\mathrm{Si}$ & & & & 0.50 & 0.50 & 0.38 & 0.53 & \\
\hline Mo & & & & 0.10 & 0.11 & & & \\
\hline $\mathrm{Cu}$ & & & $<0.05$ & & & & 0.16 & $<0.05$ \\
\hline $\mathrm{Nb} / \mathrm{Ta}$ & & & & 0.80 & 0.79 & & & \\
\hline $\mathrm{Nb}$ & & & & & & & 0.65 & \\
\hline Misc & & & & & & & 0.42 & \\
\hline
\end{tabular}

a Used in construction of loops.

\section{RESULTS AND SPECIFIC EVALUATIONS}

\subsection{Preparatory Operation}

The solutions and other experimental conditions employed in preparatory operations are listed in Tables 6-12 together with the results of analyses for corrosion products and chlorine in the various solutions. Values are also listed for the average corrosion rates of steel loop surfaces calculated from the results for nickel accumulation in solution and, where available, from oxygen consumption. In calculating the rate values it was assumed that the steel surfaces in contact with high-temperature solution corroded uniformly and that corrosion of other surfaces was negligible. In the case of the nickel data it was assumed that there was no selective oxidation of any of the components of stainless steel and that oxidized nickel was dissolved quantitatively. These assumptions were also employed in computing some values 
Table 4. Loop Construction Dota

\begin{tabular}{|c|c|c|c|c|c|c|c|}
\hline & \multicolumn{7}{|c|}{ Loop } \\
\hline . & $\mathrm{DD}$ & EE & FF & GG & $L-4-12$ & $L-4-13$ & $L-4-18$ \\
\hline Loop volume (including pressurizer), $\mathrm{ml}$ & 1505 & 1511 & 1560 & 1511 & 1542 & 1540 & 1551 \\
\hline $\begin{array}{l}\text { Pressurizer volume, empty, } \mathrm{ml} \\
\text { Pressurizer volume, loaded, } \mathrm{ml}\end{array}$ & 520 & 520 & 509 & 514 & $\begin{array}{l}534 \\
480\end{array}$ & 548 & 543 \\
\hline $\begin{array}{l}\text { Empty core volume, } \mathrm{ml} \\
\text { Loaded core volume, } \mathrm{ml}\end{array}$ & 319 & $\begin{array}{l}375 \\
303\end{array}$ & 329 & 326 & $\begin{array}{l}365 \\
314\end{array}$ & $\begin{array}{l}372 \\
302\end{array}$ & $\begin{array}{l}372 \\
320\end{array}$ \\
\hline \multicolumn{8}{|l|}{ Flow tates } \\
\hline $\begin{array}{l}\text { Pressurizer, } \mathrm{ml} / \mathrm{sec} \\
\text { Core, } \mathrm{gpm}\end{array}$ & $\begin{array}{l}6.6 \\
5.7\end{array}$ & $\begin{array}{l}5.0 \\
5.5\end{array}$ & $\begin{array}{l}6.0 \\
5.8\end{array}$ & $\begin{array}{l}6.5 \\
6.4\end{array}$ & $\begin{array}{l}7.7 \\
5.4\end{array}$ & $\begin{array}{l}5.4 \\
5.4\end{array}$ & $\begin{array}{l}6.3 \\
5.2\end{array}$ \\
\hline Pump bearing material & $a$ & $a$ & $a$ & $a$ & $\mathrm{Al}_{2} \mathrm{O}_{3}$ & $\mathrm{Al}_{2} \mathrm{O}_{3}$ & $\mathrm{Al}_{2} \mathrm{O}_{3}$ \\
\hline Pump journal material & $b$ & $c$ & $d$ & $d$ & $\mathrm{Al}_{2} \mathrm{O}_{3}$ & $\mathrm{Al}_{2} \mathrm{O}_{3}$ & $\mathrm{Al}_{2} \mathrm{O}_{3}$ \\
\hline Loop construction material & 347 SS & 347 SS & 347 SS & $3 \dot{4} \mathrm{SS}$ & $347 \mathrm{SS}^{e}$ & $347 \mathrm{SS}$ & 347 SS \\
\hline $\begin{array}{l}\text { Core and in-line channel coupon holders } \\
\text { Core annulus coupon holders } \\
\text { In-line annulus coupon holders }\end{array}$ & Zircaloy -2 & $\begin{array}{l}\text { Zircaloy-2 } \\
347 \text { SS, Zircaloy-2 }\end{array}$ & Zircaloy-2 & Zircaloy-2 & Titarium & 347 SS & $\begin{array}{l}347 \mathrm{SS} \\
347 \mathrm{SS}, \mathrm{Ti} \cdot 75 \mathrm{~A} \\
347 \mathrm{SS}, \mathrm{Ti}-75 \mathrm{~A}\end{array}$ \\
\hline Core impact specimen holders & Zircaloy- $2^{b}$ & & Zircaloy-2 & Zircaloy-2 & $347 s S^{\prime}$ & $347 \mathrm{SS}^{\circ}$ & \\
\hline In-line impact specimen holders & & & & & $347 s s^{\prime}$ & $347 \mathrm{SS}$ & \\
\hline Care tensile specimen holders & & & & & & 347 SS & \\
\hline Core annulus coupon spacers & & 347 SS, Zircaloy-2 & & & & & \\
\hline Core stress specimen holders & & $\begin{array}{l}\text { Zircaloy-2, } 348 \text { SS } \\
\text { Ti-55A }\end{array}$ & & & 347 SS, Zircaloy-2 & & Zircaloy-2 \\
\hline $\begin{array}{l}\text { In-line stress specimen holders } \\
\text { Pressurizer stress specimen holders }\end{array}$ & & & & & $\begin{array}{l}347 \mathrm{Ss}, \text { Zircaloy-2 } \\
347 \mathrm{SS} \text {, Zircaloy-2, Ti-RC-70 }\end{array}$ & & 347 SS \\
\hline Design presșure, psi & 1000 & 1000 & 1000 & 1000 & 1000 & 2000 & 2000 \\
\hline
\end{tabular}

${ }^{a}$ Graphitar No. 14 .

${ }^{b}$ Stellite $98 \mathrm{Ni2}$.

${ }^{c}$ Hardened 17-4 PH stainless steel.

$d_{17-4} \mathrm{PH}$ stainless steel.

${ }^{e}$ Core of loop constructed of Ti-55A.

$I_{\text {Assumed. }}$ 
Table 5. Loop Areas Exposed to High-Temperature Solutions

\begin{tabular}{|c|c|c|c|c|c|c|c|}
\hline \multirow{2}{*}{ Component } & \multicolumn{7}{|c|}{ Areas Wetted by Solution $\left(\mathrm{cm}^{2}\right)^{a}$} \\
\hline & $\mathrm{DD}$ & FF & GG & EE & L-4-12 & L-4-13 & L-4-18 \\
\hline $\begin{array}{l}\text { Total main circulating lines } \\
\text { (not including pump and core) }\end{array}$ & 1553 & 1553 & 1553 & 1553 & 1553 & 1516 & 1516 \\
\hline \multicolumn{8}{|l|}{ Pressurizer } \\
\hline Total area & $(706)$ & $(706)$ & $(706)$ & $(706)$ & $(706)$ & $(708)$ & (708) \\
\hline $\begin{array}{l}\text { Area wetted when containing } \\
300 \mathrm{ml} \text { of solution }\end{array}$ & 414 & 414 & 414 & $455^{b}$ & 445 & $385^{c}$ & $354^{d}$ \\
\hline Pressurizer lines & 300 & 300 & 300 & 300 & 300 & 293 & 243 \\
\hline Core & 445 & 445 & 445 & 445 & $(325)^{e}$ & 318 & 322 \\
\hline \multicolumn{8}{|l|}{ Pump } \\
\hline Scroll & 272 & 272 & 272 & 272 & 272 & 236 & 236 \\
\hline Impeller & 159 & 159 & 159 & 159 & 159 & 215 & 215 \\
\hline $\begin{array}{l}\text { Total area ( } 347 \text { stainless } \\
\text { steel) }\end{array}$ & 3143 & 3143 & 3143 & 3184 & 2729 & 2963 & 2886 \\
\hline
\end{tabular}

\footnotetext{
Unless otherwise specified values given are for stainless steel areas.

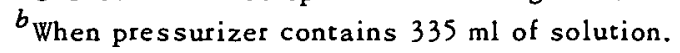

${ }^{c}$ When pressurizer contains $374 \mathrm{ml}$ of solution.

$d_{\text {When pressurizer contains } 274 \mathrm{ml} \text { of solution. }}$

$e_{\text {Ti-75A. }}$
}

for corrosion penetrations and rates from the in-pile data presented in Figs. 15-21. The corrosion penetration or rate values presented were calculated on the basis that the nickel content in type 347 stainless steel was $12.5 \%$.

\subsection{In-Pile Operation, Solution Analyses}

The results of analyses for constituents other than fission products are given in Tables 13-19. In general, the listing includes the reported concentration of a constituent in a sample, the concentration in the sample prior to dilution by wash water, which in some cases contained $\mathrm{Li}_{2} \mathrm{SO}_{4}$ tracer, and the calculated total amount of a given constituent in the loop solution. When $\mathrm{Li}_{2} \mathrm{SO}_{4}$ was added to the wash water, the correction for dilution was obtained from the amount of lithium in a sample. In a few cases the dilution factors obtained from the lithium analyses were in obvious error, and in these cases the factors were obtained from the analytical results for uranium, assuming the calculated uranium values to be correct. The calculated values for total amounts of a constituent at the time of a given sampling include corrections, where applicable, for the amounts withdrawn in prior sampling.

The reported, corrected, and calculated concentrations of uranium, sulfate, and copper in the several experiments are shown and compared graphically in Figs. 8-14. The nickel and manganese data given in the above tables are plotted against circulation time in Figs. 15-21. Values of steel corrosion which 


\begin{tabular}{|c|c|c|c|c|c|c|c|c|c|c|c|c|c|c|c|c|c|c|c|c|c|c|c|c|c|c|c|}
\hline \multirow[b]{2}{*}{ Remarks } & \multirow[b]{2}{*}{$\begin{array}{l}\text { Sample } \\
\text { Number }\end{array}$} & \multirow{2}{*}{$\begin{array}{c}\text { Total } \\
\text { Circulation } \\
\text { Time } \\
\text { (hr) }\end{array}$} & \multirow{2}{*}{$\begin{array}{c}\text { Solution } \\
\text { Withdrawn } \\
\text { for Sample } \\
\text { (ml) }\end{array}$} & \multirow{2}{*}{$\begin{array}{c}\mathrm{H}_{2} \mathrm{O} \text { Added } \\
\text { After } \\
\text { Sampling } \\
\text { (ml) }\end{array}$} & \multirow{2}{*}{$\begin{array}{l}\text { Calculated } \\
\text { Inventory } \\
\text { Volume Before } \\
\text { Sampling (mI) }\end{array}$} & \multicolumn{2}{|c|}{ Uranium } & \multicolumn{2}{|c|}{ Sulfate } & \multicolumn{2}{|c|}{ Copper } & \multicolumn{2}{|c|}{ Cobalt } & \multicolumn{2}{|c|}{ Nickel } & \multicolumn{2}{|c|}{ Chlorine } & \multicolumn{2}{|c|}{ Chromium } & \multicolumn{2}{|c|}{ Iron } & \multicolumn{2}{|c|}{ Manganese } & \multicolumn{2}{|c|}{ Silicon } & \multirow[b]{2}{*}{$\begin{array}{c}\mathrm{pH}, \\
\mathrm{Rep}\end{array}$} & \multirow[b]{2}{*}{$\begin{array}{l}\text { Overall Corrosion Rate } \\
\text { of Nickel (mpy) }\end{array}$} \\
\hline & & & & & & $\underset{\substack{R e p \\
\left(m_{g} / m 1\right)}}{2}$ & $\begin{array}{l}\operatorname{Cor}^{b} \\
(\mathrm{~g})\end{array}$ & $\begin{array}{c}\mathrm{Rep} \\
(\mathrm{mg} / \mathrm{ml})\end{array}$ & $\begin{array}{l}\operatorname{Cor}^{6} \\
(g)\end{array}$ & 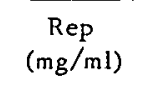 & $\begin{array}{l}\operatorname{Cor}^{6} \\
(\mathrm{~g})\end{array}$ & $\begin{array}{c}\mathrm{Rep}_{(\mu \mathrm{p}} \\
(\mu \mathrm{g} / \mathrm{m})\end{array}$ & $\begin{array}{c}\operatorname{Cor}^{b} \\
(\mathrm{mg})\end{array}$ & $\begin{array}{c}\text { Rep } \\
(\mu g / m)\end{array}$ & $\begin{array}{l}\operatorname{cor}^{b} \\
\left(m_{g}\right)\end{array}$ & $\begin{array}{c}\text { Rep } \\
(\mu g / m l)\end{array}$ & $\begin{array}{l}\cos ^{b} \\
\left(m_{B}\right)\end{array}$ & 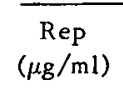 & $\begin{array}{l}\operatorname{cor}^{b} \\
\left(\mathrm{mg}_{\mathrm{g}}\right)\end{array}$ & 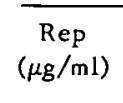 & $\begin{array}{l}\operatorname{Cor}^{b} \\
(\mathrm{mg})\end{array}$ & $\begin{array}{c}\begin{array}{c}\text { Rep } \\
(\mu g / m l)\end{array} \\
(\mu)\end{array}$ & $\begin{array}{l}\operatorname{Cor}^{b} \\
\left(m^{b}\right)^{\circ}\end{array}$ & 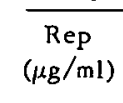 & $\begin{array}{l}\operatorname{Cor}^{b} \\
\left(\mathrm{mg}^{\mathrm{g}}\right)\end{array}$ & & \\
\hline $\begin{array}{l}\text { Disstilled } \mathrm{H}_{2} \mathrm{O}, 100-250^{\circ} \mathrm{C} \\
3 \% \text { TSP, } 100^{\circ} \mathrm{C}, \mathrm{N}_{2}(85 \text { psi) }\end{array}$ & & $\begin{array}{r}19.0 \\
2.9\end{array}$ & & & & & & & & & & & & & & & & & & & & & & & & & \\
\hline $\begin{array}{l}5 \% \mathrm{HNO}_{3} \text {, original solution before charging } \\
\text { to loop }\end{array}$ & DD-1-2 & 0 & & & & & & & & ${ }_{\mathrm{P}}^{<1}$ & & & & $\begin{array}{c}\mathrm{ND} \\
\mathrm{C}\end{array}$ & & $\begin{array}{l}: 1 \\
\mathrm{~T}\end{array}$ & & $c^{2}$ & & ${ }_{\mathrm{C}}^{41}$ & & & & & & & \\
\hline $5 \% \mathrm{HNO}_{3}, 100^{\circ} \mathrm{C}, \mathrm{N}_{2}(85 \mathrm{psi})$ & DD-1-3 & 12.5 & & & & & & & & ${ }_{\mathrm{P}}^{5}$ & & $\begin{array}{l}<1 \\
c\end{array}$ & & ${ }_{c}^{12}$ & & $\begin{array}{l}<1 \\
T\end{array}$ & & ${ }_{c}^{21}$ & & ${ }_{c}^{94}$ & & & & & & & \\
\hline & DD-1-4 & 12.5 & & & & & & & & ${ }^{9}$ & & ${ }_{c}^{10}$ & & ${ }_{c}^{15}$ & & $\begin{array}{l}<1 \\
\mathrm{r}\end{array}$ & & ${ }_{c}^{26}$ & & ${ }^{123}$ & & & & & & & \\
\hline . & DD-1-5 & 12.5 & & & & & & & & $p^{3}$ & & $c^{8}$ & & ${ }_{c}^{11}$ & & $\begin{array}{l}<1 \\
T\end{array}$ & & $c^{7}$ & & $c^{?}$ & & & & & & & \\
\hline Dissilled $\mathrm{H}_{2} \mathrm{O}, 250^{\circ} \mathrm{C}, \mathrm{O}_{2}(70 \mathrm{psi})$ & DD-1-12 & 12.4 & & & & & & & & $\begin{array}{r}\mathrm{ND} \\
\mathrm{p}\end{array}$ & & $\begin{array}{r}\mathrm{ND} \\
\mathrm{C}\end{array}$ & & No & & $\underset{T}{<1}$ & & $c^{3}$ & & $\begin{array}{r}\mathrm{ND} \\
\mathrm{C}\end{array}$ & & & & & & & \\
\hline & $\mathrm{DD}-1-13$ & 12.4 & & & & & & & & $\begin{aligned} \text { ND } \\
\mathrm{P}\end{aligned}$ & & $\begin{array}{c}\text { No } \\
\text { C }\end{array}$ & & No & & $\stackrel{<1}{<1}$ & & $c^{5}$ & & $\begin{array}{c}\text { ND } \\
C\end{array}$ & & & & & & & \\
\hline $\begin{array}{l}\text { Normal } \mathrm{UO}_{2} \mathrm{SO}_{4} \text { solution before charging } \\
\text { to loop }\end{array}$ & $D D-1-1$ & 0 & & & & $\stackrel{28.5}{T}$ & & $\begin{array}{c}15.5 \\
\mathrm{IE}\end{array}$ & & $\stackrel{1.91}{P}$ & & $\stackrel{\mathrm{N} n}{\mathrm{p}}$ & & $\stackrel{\mathrm{ND}}{\mathrm{p}}$ & & $\stackrel{\mathrm{ND}}{\mathrm{N}}$ & & $c^{1}$ & & ${ }_{c}^{10}$ & & & & & & 2.0 & \\
\hline & $D D-1-1(C)$ & 0 & & & & & & & & $\begin{array}{c}1.80 \\
\mathrm{~S}\end{array}$ & & & & $\begin{array}{c}<4 \\
\mathrm{~s}\end{array}$ & & & & $\begin{array}{c}<1 \\
s\end{array}$ & & & & $\begin{array}{c}<1 \\
s\end{array}$ & & $\begin{array}{c}2.3 \\
\mathrm{~s}\end{array}$ & & & \\
\hline Charged solution to loop, $250^{\circ} \mathrm{C}, \mathrm{O}_{2}(70 \mathrm{psi})$ & & & & & & & & & & & & & & & & & & & & & & & & & & & \\
\hline Sample from main loop & $D D-1-15$ & 2 & 9 & 0 & 1109 & $\begin{array}{c}26.6 \\
T\end{array}$ & 29.5 & $\begin{array}{c}15.5 \\
\mathrm{IE}\end{array}$ & 17.2 & $\begin{array}{c}2.05 \\
P\end{array}$ & 2.27 & $\begin{array}{r}\mathrm{ND} \\
\mathrm{P}\end{array}$ & & ${ }_{\mathrm{p}}^{8}$ & 9 & $\begin{array}{l}<1 \\
T\end{array}$ & 1 & $c^{8}$ & 9 & $\begin{array}{l}17 \\
c\end{array}$ & 19 & & & & & 2.0 & \\
\hline Sample from back of pump & $D D \cdot 1-16$ & 2 & 9 & 1.2 & 1100 & $\underset{\mathrm{T}}{29.5}$ & 32.7 & $\begin{array}{c}15.8 \\
\mathrm{IE}\end{array}$ & 17.6 & $\begin{array}{c}1.92 \\
\mathrm{P}\end{array}$ & 2.13 & $\begin{array}{r}\mathrm{ND} \\
\mathrm{P}\end{array}$ & & ${ }_{\mathrm{P}}^{8}$ & 9 & $T^{3}$ & 3 & $c_{c}^{8}$ & 9 & ${ }_{c}^{21}$ & 23 & & & & & 2.0 & \\
\hline Sample from main loop & DD $11-17$ & 7 & 7 & 0 & 1092 & $\underset{\mathrm{T}}{28.3}$ & 31.0 & $\begin{array}{l}16.2 \\
\mathrm{IE}\end{array}$ & 18.0 & $\begin{array}{c}1.96 \\
\mathrm{P}\end{array}$ & 2.17 & $\begin{array}{r}\text { ND } \\
\mathrm{P}\end{array}$ & & ${ }_{\mathrm{P}}^{22}$ & 24 & $\stackrel{<1}{T}_{1}^{<1}$ & 1 & $\stackrel{21}{c}^{21}$ & 23 & ${ }_{c}^{34}$ & 38 & & & & & 2.0 & \\
\hline Sample from back of pump & DD $-1-18$ & 7 & 7 & 0 & 1085 & $\begin{array}{c}30.8 \\
\mathrm{~T}\end{array}$ & 34.1 & $\begin{array}{c}16.7 \\
\mathrm{IE}\end{array}$ & 18.5 & $\begin{array}{c}1.98 \\
P\end{array}$ & 2.19 & $\begin{array}{r}\text { ND } \\
\text { P }\end{array}$ & & $\begin{array}{l}25 \\
P\end{array}$ & 27 & ${ }_{\mathrm{T}}^{<1}$ & 1 & $\begin{array}{l}16 \\
c\end{array}$ & 18 & ${ }_{c}^{26}$ & 29 & & & & & 2.0 & \\
\hline Sample from loop & $D D \cdot 1-19$ & 22 & 30 & 0 & 1078 & $\begin{array}{r}28.4 \\
\mathrm{~T}\end{array}$ & 31.5 & $\begin{array}{c}15.5 \\
1 \mathrm{E}\end{array}$ & 17.2 & $\begin{array}{c}1.95 \\
P\end{array}$ & 2.17 & $\begin{array}{l}19 \\
\mathrm{P}\end{array}$ & 21 & $\begin{array}{l}90 \\
\mathrm{P}\end{array}$ & 97 & $\begin{array}{c}3.7 \\
\mathrm{r}\end{array}$ & 4 & $\begin{array}{c}5.8 \\
c\end{array}$ & 7 & $\begin{array}{c}4.3 \\
c\end{array}$ & 5 & & & & & 2.0 & \\
\hline Sample from loop after shutdown at $\mathrm{Y}-12$ & $\mathrm{DD}-1-20$ & 24 & 6 & 0 & 1048 & $\begin{array}{c}28.3 \\
T\end{array}$ & 31.4 & $\underset{\mathrm{IE}}{16.2}$ & 18.4 & $\stackrel{1.76}{P}$ & 1.97 & $\begin{array}{r}\text { ND } \\
P\end{array}$ & & ${ }_{\mathrm{P}}^{77}$ & 84 & $\underset{\mathrm{r}}{<1}$ & 1 & $\begin{array}{l}2.5 \\
c\end{array}$ & $3^{.}$ & ${ }_{c}^{38}$ & 41 & $\begin{array}{l}19 \\
\mathrm{~s}\end{array}$ & 20 & $\begin{array}{c}180 \\
S\end{array}$ & 189 & 2.1 & 3.8 \\
\hline $\begin{array}{l}\text { Loop inoperative about } 20 \mathrm{hr} \text { berween shut- } \\
\text { down a } \mathrm{Y}-\mathrm{Y}-12 \text { and startur at } \mathrm{ORNL} \\
\text { (inventery not removed from loop during } \\
\text { this period) }\end{array}$ & & & & & & & & & & & & & & & & & & & $!$ & & & & & & & & \\
\hline Sample from main loop & DD-1-23 & 37.8 & 10 & 16.9 & 1042 & $\begin{array}{c}27.3 \\
T\end{array}$ & 30.4 & $\begin{array}{l}16.6 \\
\mathrm{IE}\end{array}$ & 18.9 & $\begin{array}{c}2.15 \\
p\end{array}$ & 2.37 & $\begin{array}{r}\mathrm{ND} \\
\mathrm{P}\end{array}$ & & $\begin{array}{l}85 \\
P\end{array}$ & 92 & $T^{3}$ & s & ${ }_{c}^{25}$ & $27:$ & ${ }_{c}^{30}$ & 32 & & & & & 2.1 & \\
\hline $\begin{array}{l}\text { Sample from main loop using loop } \\
\text { sampling procedure }\end{array}$ & DD $1-25$ & 64.4 & 47.2 & 0 & 1049 & $\begin{array}{c}25.7 \\
\mathrm{~T}\end{array}$ & 29.1 & $\underset{\mathrm{IE}}{16.9}$ & 19.5 & $\begin{array}{c}1.90 \\
P\end{array}$ & 2.15 & $\stackrel{163}{P}$ & 172 & $\begin{array}{c}131 \\
\mathrm{P}\end{array}$ & 142 & & & $\begin{array}{c}34 \\
c\end{array}$ & 37 & ${ }_{c}^{90}$ & 96 & & & & & 2.8 & \\
\hline $\begin{array}{l}\text { Sample from main loop after pump } \\
\text { shurdown }\end{array}$ & $D D-1-26$ & 84.9 & 10 & 0 & 1032 & $\begin{array}{c}28.2 \\
T\end{array}$ & 32.6 & $\begin{array}{c}15.5 \\
\mathrm{IE}\end{array}$ & 18.6 & $\stackrel{1.96}{P}$ & 2.26 & $\begin{array}{c}125 \\
P\end{array}$ & 138 & $\begin{array}{c}123 \\
P\end{array}$ & 138 & $\begin{array}{l}8 \\
T\end{array}$ & 9 & $\begin{array}{l}46 \\
c\end{array}$ & 50 & $\begin{array}{l}19 \\
c\end{array}$ & 25 & $\begin{array}{l}15 \\
s\end{array}$ & 17 & $\begin{array}{l}19.2 \\
s\end{array}$ & 31 & 2.0 & 1.8 \\
\hline $\begin{array}{l}\text { Sample from lomp inventory after } \\
\text { temoval from loop }\end{array}$ & nD-1-1-29. & 84.9 & & & 1012 & & & & & & & & & & & & & ${ }^{69}$ & 73 & & & $\begin{array}{l}25 \\
\text { s }\end{array}$ & 27 & & & & \\
\hline
\end{tabular}

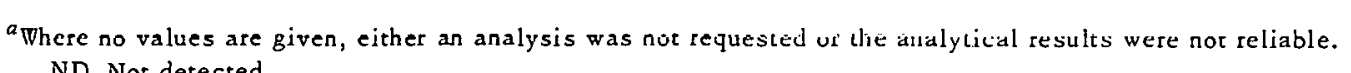

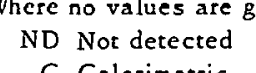

c Colorimeteric
T Titramerric

IE I Ion exchange, volumerric

G Polarographic
G Gravimetic
S Specrouraphic

Amount present plus accumulated amount previously withdrawn as samples. 
Table 7. Analyses of Samples from Loop Inventory and Overall Corrosion Rates During Preparatory Operations, ${ }^{a}$ Experiment EE

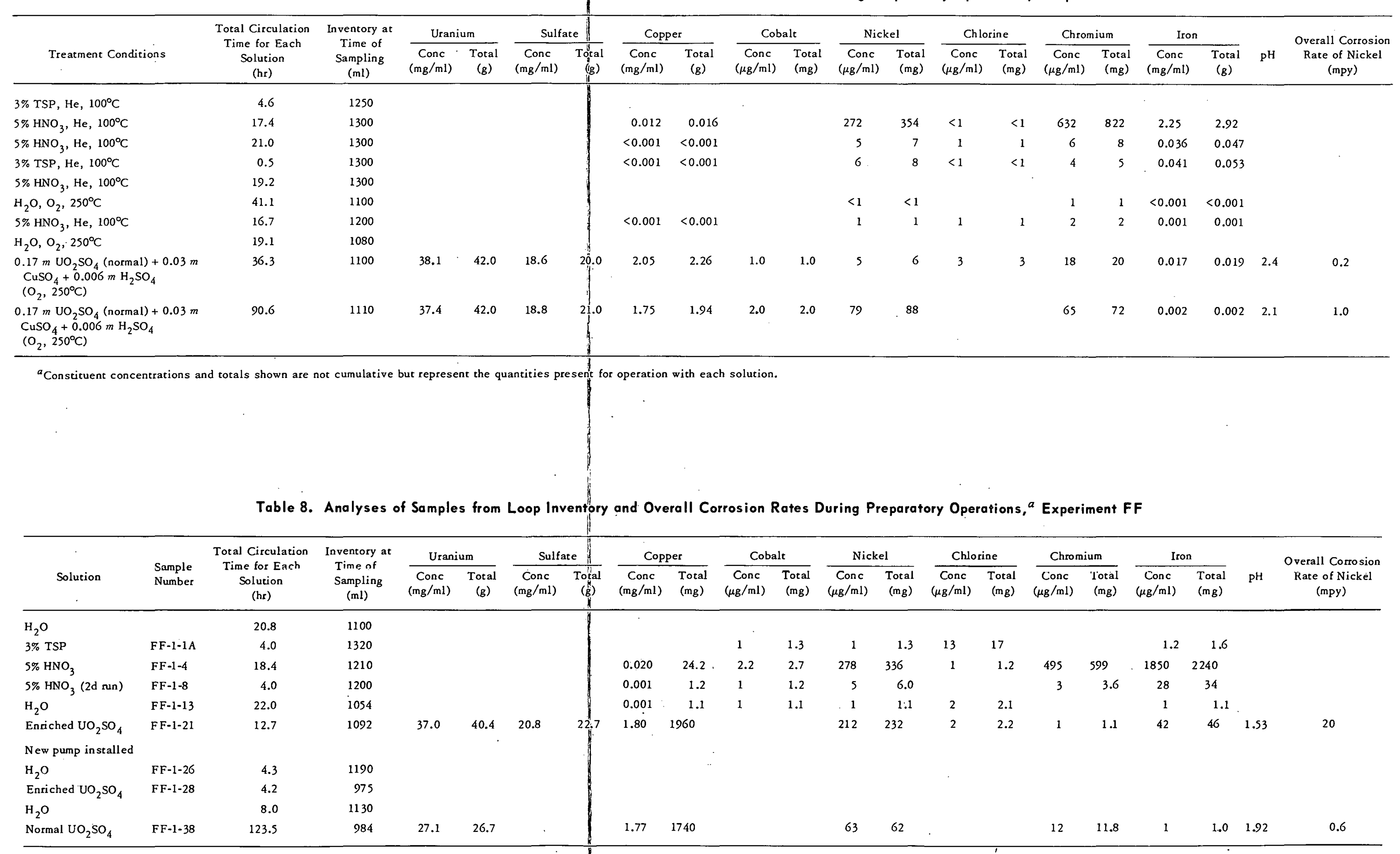

${ }^{a}$ Constituent concentrations and totals shown are not cumulative but represent the quantities present for operation with each solution. 
Table 9. Analyses of Samples from Loop Inventory and Overall Corrosion Rates During Preparatory Operations, ${ }^{a}$ Experiment GG

\begin{tabular}{|c|c|c|c|c|c|c|c|c|c|c|c|c|c|c|c|c|c|c|c|c|}
\hline \multirow[b]{2}{*}{ Solution } & \multirow{2}{*}{$\begin{array}{l}\text { Total Circulation } \\
\text { Time for Each } \\
\text { Solution } \\
\text { (hr) }\end{array}$} & \multirow{2}{*}{$\begin{array}{l}\text { Inventory at } \\
\text { Time of } \\
\text { Sampling } \\
\text { (ml) }\end{array}$} & \multicolumn{2}{|c|}{ Uranium } & \multicolumn{2}{|c|}{ Sulfate } & \multicolumn{2}{|c|}{ Copper } & \multicolumn{2}{|c|}{ Nickel } & \multicolumn{2}{|c|}{ Iron } & \multicolumn{2}{|c|}{ Chromium } & \multicolumn{2}{|c|}{ Chlorine } & \multicolumn{2}{|c|}{ Cobalt } & \multirow[b]{2}{*}{$\mathrm{pH}$} & \multirow{2}{*}{$\begin{array}{l}\text { Overall Corrosion } \\
\text { Rate of Nickel } \\
\text { (mpy) }\end{array}$} \\
\hline & & & $\begin{array}{c}\text { Conc } \\
(\mathrm{mg} / \mathrm{ml})\end{array}$ & $\begin{array}{l}\text { Total } \\
(\mathrm{g})\end{array}$ & $\begin{array}{c}\text { Conc } \\
(\mathrm{mg} / \mathrm{ml})\end{array}$ & $\begin{array}{c}\text { Total } \\
\text { (g) }\end{array}$ & $\begin{array}{c}\text { Conc } \\
(\mathrm{mg} / \mathrm{ml})\end{array}$ & $\begin{array}{c}\text { Total } \\
\text { (g) }\end{array}$ & $\begin{array}{c}\text { Conc } \\
(\mu \mathrm{g} / \mathrm{ml})\end{array}$ & $\begin{array}{c}\text { Total } \\
\text { (mg) }\end{array}$ & $\begin{array}{c}\text { Conc } \\
(\mu \mathrm{g} / \mathrm{ml})\end{array}$ & $\begin{array}{l}\text { Total } \\
(\mathrm{mg})\end{array}$ & $\begin{array}{c}\text { Conc } \\
(\mu \mathrm{g} / \mathrm{ml})\end{array}$ & $\begin{array}{c}\text { Total } \\
\text { (mg) }\end{array}$ & $\begin{array}{c}\text { Conc } \\
(\mu \mathrm{g} / \mathrm{ml})\end{array}$ & $\begin{array}{r}\text { Total } \\
(\mathrm{mg})\end{array}$ & $\begin{array}{c}\text { Conc } \\
(\mu \mathrm{g} / \mathrm{ml})\end{array}$ & $\begin{array}{c}\text { Total } \\
\text { (mg) }\end{array}$ & & \\
\hline $3 \% \mathrm{TSP}, \mathrm{He}, 100^{\circ} \mathrm{C}$ & 4.5 & 1300 & & & & & & & $<1$ & 1 & 3 & 4 & $<1$ & 1 & & & & & & \\
\hline $5 \% \mathrm{HNO}_{3}, \mathrm{He}, 100^{\circ} \mathrm{C}$ & 12.0 & 1300 & & & & & & & 17 & 22 & 65 & 85 & 7 & 9 & $<1$ & 1 & 2 & 3 & & \\
\hline $\mathrm{H}_{2} \mathrm{O}, \mathrm{O}_{2}, 250^{\circ} \mathrm{C}$ & 33.2 & 1300 & & & & & $<0.001$ & 0.001 & $<1$ & 1 & $<1$ & 1 & 2 & 3 & $<1$ & 1 & 2 & 3 & & \\
\hline Natural-uranium $\mathrm{UO}_{2} \mathrm{SO}_{4}, \mathrm{O}_{2}, 250^{\circ} \mathrm{C}$ & 41.7 & 1160 & 37.7 & 43.7 & 21.8 & 25.3 & 1.98 & 2.30 & 103 & 120 & 18 & 21 & 7 & 8 & 4 & $s$ & $<1$ & 1 & 1.3 & 3.1 \\
\hline Natural-uranium $\mathrm{UO}_{2} \mathrm{SO}_{4}, \mathrm{O}_{2}, 250^{\circ} \mathrm{C}$ & 63.3 & 1160 & 39.0 & 45.2 & & & 1.98 & 2.30 & 53 & 62 & 6 & 7 & 24 & 28 & 4 & 5 & 9 & 10 & 1.3 & 1.1 \\
\hline
\end{tabular}

${ }^{a}$ Constiment concentrations and totals shown are not cumulative but represent the quantities present for operation with each solution.

Table 10. Analyses of Samples from Loop Inventory and Overall Corrosion Rates During Preparatory Operations, ${ }^{a}$ Experiment L.4-112

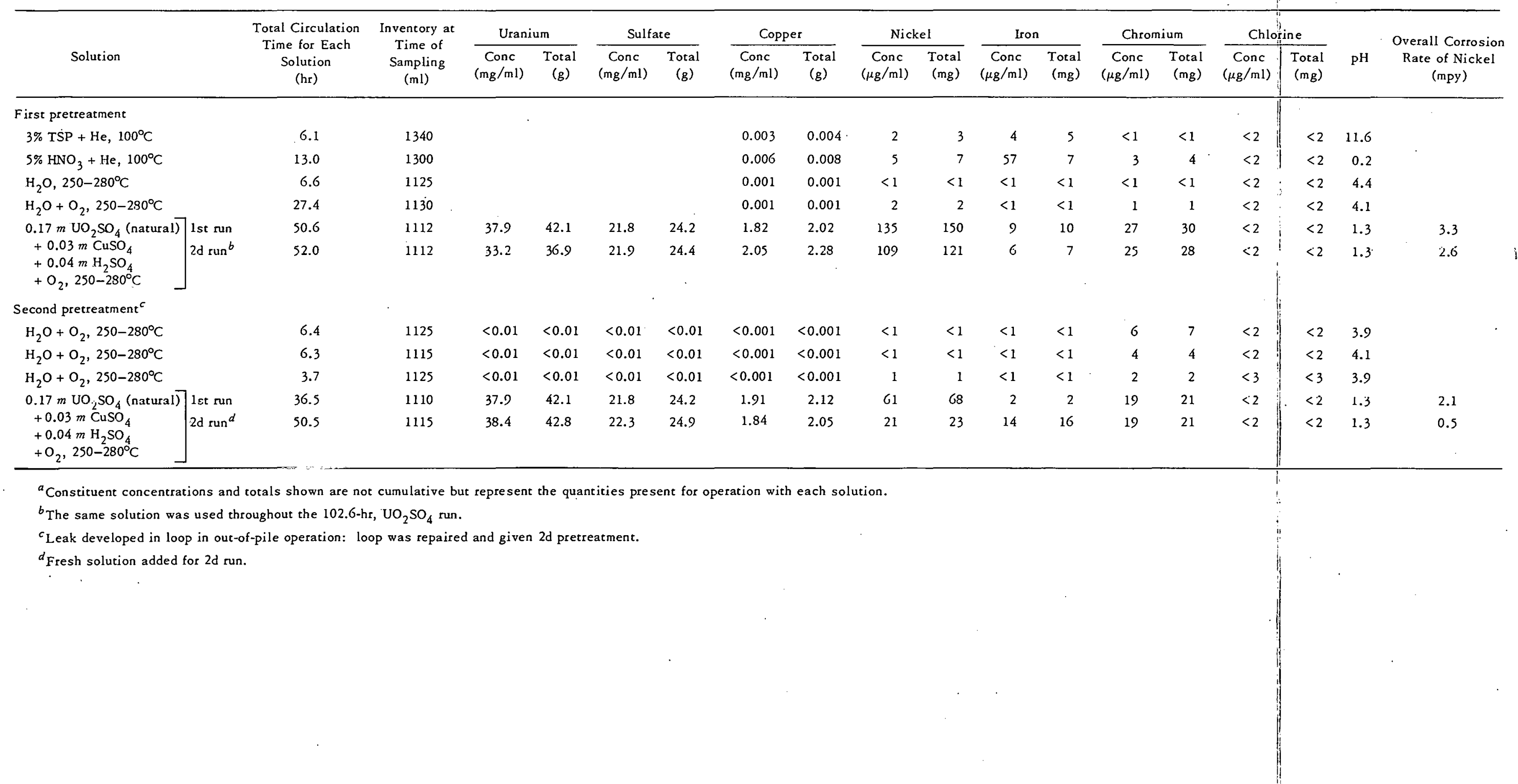


Table 11. Analyses of Samples from Loop Inventory and Overall Corrosion Rates During Preparatory Operations, ${ }^{a}$ Experiment L-4-13

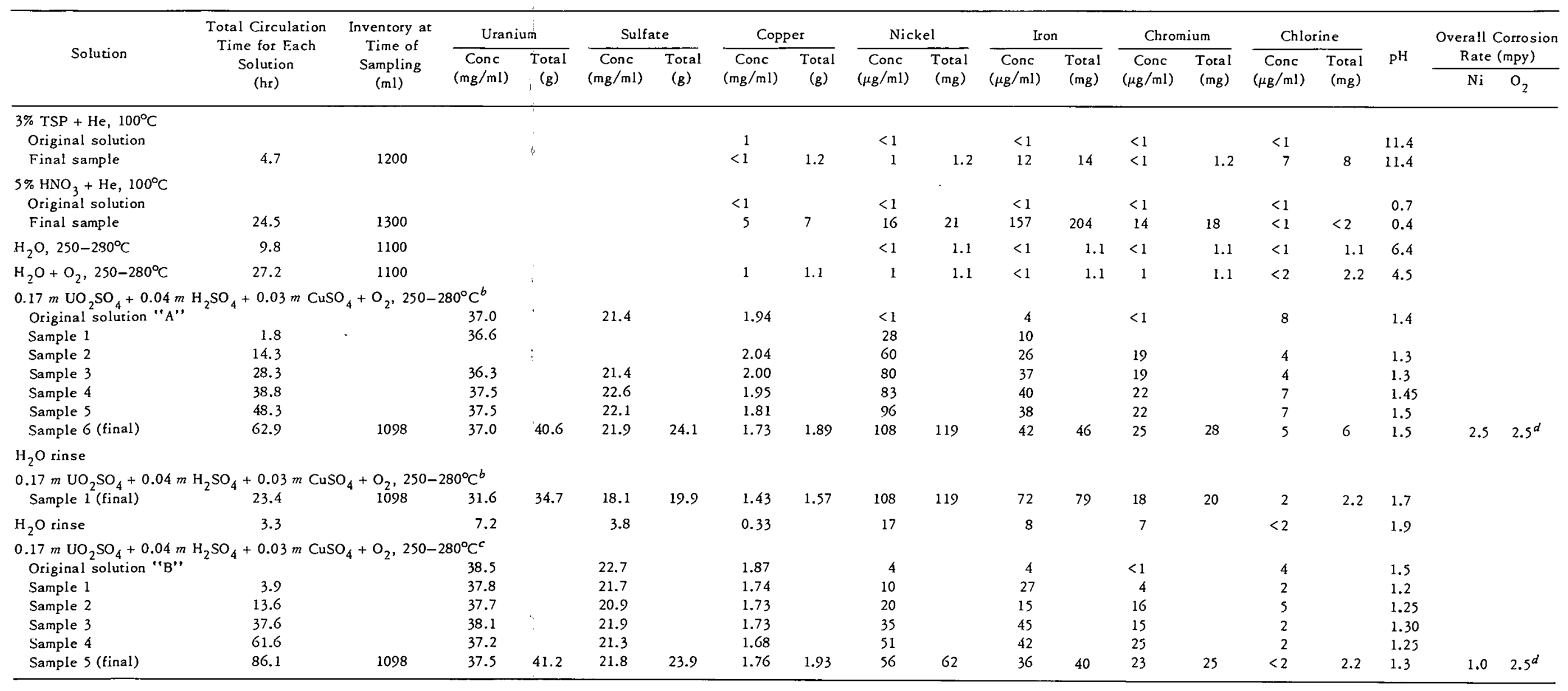

${ }^{a}$ Constituent concentrations and totals shown are not cumulative but represent the quantities present for operation with each solution.

${ }^{b}$ The 23.4-hr run was a separate run using the solution drained from the 62.9-hr run plus $60 \mathrm{ml}$ of fresh solution.

$c_{\text {Fresh solution. }}$

${ }^{d}$ Average rate for both runs. 
Table 12. Analyses of Samples from Loop Inventory and Overall Corrosion Rates During Preparatory Operations, ${ }^{a}$ Experiment L-4.18

\begin{tabular}{|c|c|c|c|c|c|c|c|c|c|c|c|c|c|c|c|c|c|c|c|}
\hline \multirow[b]{2}{*}{ Solution } & \multirow{2}{*}{$\begin{array}{l}\text { Total Circulation } \\
\text { Time for Each } \\
\text { Solution } \\
\text { (hr) }\end{array}$} & \multirow{2}{*}{$\begin{array}{c}\text { Inventory at } \\
\text { Time of } \\
\text { Sampling } \\
\text { (ml) }\end{array}$} & \multicolumn{2}{|c|}{ Uranium } & \multicolumn{2}{|c|}{$\begin{array}{c}\text { Sulfate } \\
\end{array}$} & \multicolumn{2}{|c|}{ Copper } & \multicolumn{2}{|c|}{ Nickel } & \multicolumn{2}{|c|}{ Iron } & \multicolumn{2}{|c|}{ Chromium } & \multicolumn{2}{|c|}{ Chlorine } & \multirow[b]{2}{*}{$\mathrm{pH}^{\mathrm{H}}$} & \multicolumn{2}{|c|}{$\begin{array}{l}\text { Overall } \\
\text { Corrosion }\end{array}$} \\
\hline & & & $\begin{array}{c}\text { Conc } \\
(\mathrm{mg} / \mathrm{ml})\end{array}$ & $\begin{array}{c}\text { Total } \\
(\mathrm{g})\end{array}$ & $\begin{array}{c}\text { Conc } \\
(\mathrm{mg} / \mathrm{ml})\end{array}$ & $\begin{array}{c}\text { Total } \\
(\mathrm{g})\end{array}$ & $\begin{array}{c}\text { Conc } \\
(\mu \mathrm{g} / \mathrm{ml})\end{array}$ & $\begin{array}{l}\text { Total } \\
\sqrt{\left(\mathrm{m}_{\mathrm{g}}\right.}\end{array}$ & $\begin{array}{c}\text { Conc } \\
\left(\mu_{B} / \mathrm{ml}\right)\end{array}$ & $\begin{array}{c}\text { Total } \\
\left(\mathrm{mg}_{\mathrm{g}}\right.\end{array}$ & $\begin{array}{c}\text { Conc } \\
(\mu, \mu / m 1)\end{array}$ & $\begin{array}{l}\text { Total } \\
(\mathrm{mg})\end{array}$ & $\begin{array}{c}\text { Conc } \\
(\mu \mathrm{g} / \mathrm{mL})\end{array}$ & $\begin{array}{c}\text { Total } \\
\text { (mg) }\end{array}$ & $\begin{array}{c}\text { Conc } \\
(\mu \mathrm{g} / \mathrm{ml})\end{array}$ & $\begin{array}{c}\text { Total } \\
(\mathrm{mg})\end{array}$ & & & 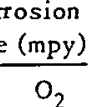 \\
\hline $3 \% \mathrm{TSP}+\mathrm{He}, 95^{\circ} \mathrm{C}$ & 4.5 & 1250 & & & & & & & $<1$ & 1.3 & 8 & 10 & $<1$ & 1 & 2 & 3 & 11.5 & & \\
\hline $5 \% \mathrm{HNO}_{3}+\mathrm{He}, 95^{\circ} \mathrm{C}$ & 23.8 & 1250 & & & & & & & 12 & 15.0 & 106 & 133 & 9 & 11 & 5 & 8 & 0.4 & & \\
\hline $\mathrm{H}_{2} \mathrm{O}, 235-275^{\circ} \mathrm{C}$ & 12.0 & 1127 & & & & & & & $<1$ & 1.1 & $<1$ & 1 & $<1$ & 1 & $<2$ & 2 & 7.0 & & \\
\hline $\mathrm{H}_{2} \mathrm{O}, \mathrm{O}_{2}, 235-275^{\circ} \mathrm{C}$ & 25.1 & 1115 & & & & & & & $<1$ & 1.1 & $<1$ & 1 & $<1$ & 1 & $<1$ & 1 & 4.7 & & \\
\hline $\mathrm{H}_{2} \mathrm{O}, 235-275^{\circ} \mathrm{C}$ & 5.3 & 1115 & & & & & & & $<1$ & 1.1 & $<1$ & 1 & $<1$ & 1 & 8 & 9 & 6.2 & & \\
\hline $\left.\begin{array}{l}0.17 \mathrm{~m} \mathrm{UO}_{2} \mathrm{SO}_{4}+\mathrm{O}_{2}, 235-275^{\circ} \mathrm{C} \\
0.10 \mathrm{CuSO}_{4}+\mathrm{O}_{2}, 235-275^{\circ} \mathrm{C} \\
0.025 \mathrm{~m} \mathrm{H} \mathrm{SO}_{4}+\mathrm{O}_{2}, 235-275^{\circ} \mathrm{C}\end{array}\right\}$ & 107.2 & 1115 & 38.7 & 43.2 & 27.3 & 30.5 & 602 & 671.2 & 140 & 156 & 223 & 248 & 58 & 65 & $<2$ & .2 & 1.6 & 1.9 & 3.6 \\
\hline $\left.\begin{array}{l}0.17 \mathrm{~m} \mathrm{UO}_{2} \mathrm{SO}_{4}+\mathrm{O}_{2}, 235-275^{\circ} \mathrm{C} \\
0.10 \mathrm{CuSO} \mathrm{O}_{4}+\mathrm{O}_{2}, 235-275^{\circ} \mathrm{C} \\
0.025 \mathrm{mH}_{2} \mathrm{SO}_{4}+\mathrm{O}_{2}, 235-275^{\circ} \mathrm{C}\end{array}\right\}$ & 53.6 & 1115 & 39.4 & 43.9 & 26.9 & 30.0 & 614 & 684 & 16 & 18 & 98 & 109 & 32 & 36 & 2 & 2 & 1.5 & 0.4 & 0.2 \\
\hline
\end{tabular}

Table 13. Analyses of Samples From Loop Inventory During Enriched-Solution Operation, ${ }^{a}$ Loop DD

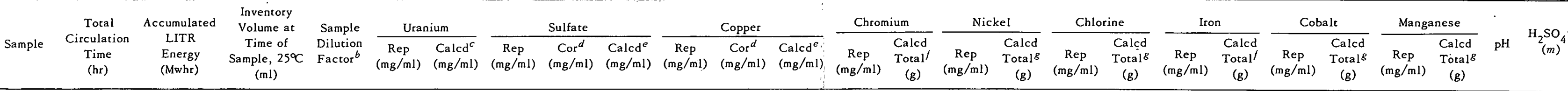

\begin{tabular}{|c|c|c|c|c|c|c|c|c|c|c|c|c|c|c|c|c|c|c|c|c|c|c|c|c|c|c|}
\hline riginal solutio & & & 1059 & & 38.7 & & 20.4 & & & 1.92 & & & 0.104 & & ND & & $<0.001$ & & ND & & ND & & $<0.002$ & & 1.80 & \\
\hline $\begin{array}{l}\text { akeup solutior } \\
\text { DD-1-29 }\end{array}$ & $\begin{array}{c}\mathrm{H}_{2} \mathrm{O} \text { only } \\
{ }_{2.4}\end{array}$ & 0 & 1059 & 1.07 & 36.1 & 38.7 & 20.6 & 22.0 & 20.4 & 1.77 & 1.89 & 1.92 & 0.073 & 0.083 & ND & 0 & 0.001 & 0.001 & ND & 0 & ND & 0 & 0.016 & 0.017 & 2.00 & 0.011 \\
\hline DD-1-30 & 12.7 & 0 & 1047 & 1.24 & 31.0 & 38.6 & 17.0 & 21.1 & 20.3 & 1.52 & 1.88 & 1.91 & 0.059 & 0.077 & ND & 0 & 0.001 & 0.001 & ND & 0 & ND & 0 & 0.012 & 0.015 & 2.25 & 0.007 \\
\hline DD-1-31 & 23.2 & 0 & 1032 & 1.13 & 33.9 & 38.6 & 19.7 & 22.3 & 20.2 & 1.82 & 2.06 & 1.90 & 0.057 & 0.066 & ND & 0 & 0.001 & 0.001 & ND & 0 & ND & 0 & 0.012 & 0.014 & 2.25 & 0.006 \\
\hline DD-1-31.5 & 29.4 & 0 & 1049 & 1.18 & 31.2 & 37.0 & 18.7 & 22.1 & 19.3 & 1.50 & 1.77 & 1.82 & 0.054 & 0.064 & ND & 0 & 0.001 & 0.001 & ND & 0 & ND & 0 & & & 2.00 & 0.012 \\
\hline DD-1-33 & 51.7 & 4.3 & 1048 & 1.10 & 33.3 & 36.8 & 18.8 & 20.7 & 19.2 & 1.61 & 1.77 & 1.81 & 0.046 & 0.053 & ND & 0 & 0.001 & 0.001 & ND & 0 & ND & 0 & 0.006 & 0.007 & 2.00 & 0.011 \\
\hline DD-1-33 & 72.6 & 19.6 & 1047 & 1.11 & 32.7 & 36.3 & 17.8 & 19.8 & 18.9 & 1.61 & 1.79 & 1.78 & 0.040 & 0.046 & ND & 0 & 0.001 & 0.001 & & & ND & 0 & & & 2.00 & 0.071 \\
\hline DD- $-1-34$ & .95 .4 & 49.0 & 1045 & 1.21 & 29.7 & 35.8 & 16.5 & 20.0 & 18.6 & 1.42 & 1.72 & 1.75 & 0.018 & 0.023 & ND & 0 & 0.001 & 0.001 & & & ND & 0 & & & 2.10 & 0.010 \\
\hline DD-1-35 & 120.2 & 90.3 & 1044 & 1.30 & 26.9 & 35.1 & 17.0 & 22.1 & 18.2 & 1.43 & 1.86 & 1.72 & 0.003 & 0.004 & 0.079 & 0.107 & 0.001 & 0.001 & & & ND & 0 & & & 2.05 & 0.012 \\
\hline DD-1-36 & 192.9 & 246.5 & 1042 & 1.13 & 30.8 & 34.7 & 15.7 & 17.7 & 17.9 & 1.38 & 1.56 & 1.69 & 0.015 & 0.018 & 0.143 & 0.169 & 0.001 & 0.001 & 0.023 & 0.027 & 0.087 & 0.100 & & & 2.20 & 0.007 \\
\hline DD-1-37 & 289.0 & 482.0 & 1042 & 1.15 & 29.7 & 34.2 & 16.6 & 19.1 & 17.6 & 1.42 & 1.63 & 1.66 & 0.015 & 0.018 & 0.277 & 0.332 & 0.001 & 0.001 & 0.017 & 0.020 & 0.142 & 0.170 & & & 2.60 & \\
\hline DD-1-38 & 435.5 & 840.0 & 1039 & 1.23 & 27.3 & 33.6 & 16.2 & 19.9 & 17.3 & 1.41 & 1.73 & 1.64 & 0.017 & 0.022 & 0.368 & 0.472. & $<0.001$ & 0.001 & 0.018 & 0.023 & 0.121 & 0.160 & & & 2.60 & \\
\hline DD-1-39 & 465.5 & 840.0 & 1037 & 1.03 & 32.1 & 33.2 & 17.9 & 18.4 & 17.0 & 1.55 & 1.60 & 1.62 & 0.042 & 0.045 & 0.410 & 0.439 & $<0.001$ & 0.001 & 0.028 & 0.030 & 0.119 & 0.140 & & & 2.65 & \\
\hline
\end{tabular}

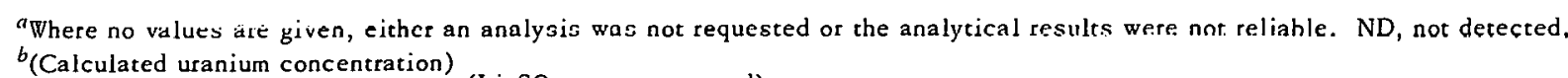

(Reported uranium concentration) $\left(\mathrm{Li}_{2} \mathrm{SO}_{4}\right.$ tracer not used.

(Reported dranium concentration)
"Determined from calculated uranium and inventory balante.

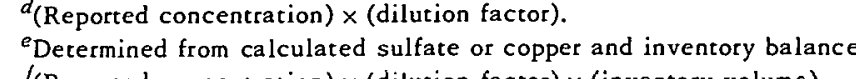

(Reported concentration corrected for sample dilution and amounts withdrawn in previous samples) $\times$ (inventory volume) 
Table 14. Analyses of Samples from Loop Inventory During Enriched-Solution Operations, ${ }^{a}$ Loop EE

\begin{tabular}{|c|c|c|c|c|c|c|c|c|c|c|c|c|c|c|c|c|c|c|c|c|c|c|c|c|c|c|c|c|c|c|c|c|}
\hline \multirow[b]{2}{*}{ Sample } & \multirow{2}{*}{$\begin{array}{c}\text { Total } \\
\text { Circulation } \\
\text { Time } \\
\text { (hr) }\end{array}$} & \multirow{2}{*}{$\begin{array}{c}\text { Accumulated } \\
\text { LIrR } \\
\text { Energ } \\
\text { (Mwhr) }\end{array}$} & \multirow{2}{*}{$\begin{array}{l}\text { Elapsed Time } \\
\text { from IITR } \\
\text { Shutdown } \\
\text { to Sampling } \\
\text { (hr) }\end{array}$} & \multirow{2}{*}{$\begin{array}{c}\text { Inventory } \\
\text { Volume at } \\
\text { Time of } \\
\text { Sampling, } 25^{\circ} \mathrm{C} \\
\text { (ml) }\end{array}$} & \multirow[b]{2}{*}{$\begin{array}{l}\text { Sample } \\
\text { Dilutiton } \\
\text { Factor }\end{array}$} & \multicolumn{3}{|c|}{ Uranium } & \multicolumn{3}{|c|}{ Sulfate } & \multicolumn{3}{|c|}{ Copper } & \multicolumn{2}{|c|}{ Cobalt } & \multicolumn{2}{|c|}{ Nickel } & \multicolumn{2}{|c|}{ Chlorine } & \multicolumn{2}{|c|}{$\frac{\text { Chromium }}{\text { Calcd }}$} & \multicolumn{2}{|c|}{$\frac{\text { Iron }}{\text { Calc }}$} & \multicolumn{2}{|c|}{$\frac{\text { Zirconium }}{\text { Calcd }}$} & \multicolumn{2}{|c|}{ Manganese } & \multicolumn{2}{|c|}{ Titanium } & \multirow[b]{2}{*}{$\mathrm{pH}$} & \multirow[b]{2}{*}{ 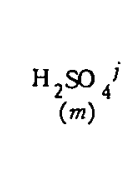 } \\
\hline & & & & & & $\overline{\substack{\mathrm{Rep} \\
(\mathrm{mg} / \mathrm{ml})}}$ & 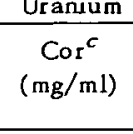 & $\begin{array}{c}\mathrm{Caldd}^{d} \\
(\mathrm{mg} / \mathrm{ml})\end{array}$ & $\overline{\substack{\text { Rep } \\
(\mathrm{mg} / \mathrm{ml})}}$ & 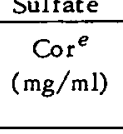 & $\begin{array}{c}\begin{array}{c}\text { Calcd } f^{\prime} \\
(\mathrm{mg} / \mathrm{ml})\end{array} \\
\text { (n) }\end{array}$ & $\overline{\substack{\text { Rep } \\
(\mathrm{mg} / \mathrm{ml})}}$ & $\begin{array}{c}\text { copper } \\
\text { Cor } \\
(\mathrm{mg} / \mathrm{ml})\end{array}$ & $\begin{array}{c}\begin{array}{c}\text { Calcd } \\
(\mathrm{mg} / \mathrm{ml})\end{array} \\
\text { (a) }\end{array}$ & $\underset{\substack{\mathrm{Rep} \\
\left(\mathrm{mg}_{\mathrm{g} / \mathrm{ml}}\right.}}{\mathrm{R}}$ & $\begin{array}{c}\text { Calcd d } \\
\text { Total } \\
\text { (g) }\end{array}$ & $\underset{\substack{\mathrm{Rep} \\
(\mathrm{mg} / \mathrm{ml})}}{\cos }$ & $\begin{array}{c}\text { Calcd } \\
\text { Totat } \\
\text { (g) }\end{array}$ & $\underset{\substack{\mathrm{Rep} \\
(\mathrm{mg} / \mathrm{ml})}}{\cos ^{2}}$ & $\begin{array}{l}\text { Calcd } \\
\text { Totali }^{1} \\
(\text { (a) }\end{array}$ & 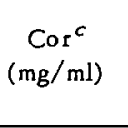 & $\begin{array}{c}\text { Calcd } \\
\text { 'rotal } \\
(\mathrm{g})\end{array}$ & $\underset{(\mathrm{mg} / \mathrm{ml})}{\operatorname{cor}^{c}}$ & $\begin{array}{c}\text { Calcd } \\
\text { Total } \\
\text { (g) }\end{array}$ & $\underset{\left(\mathrm{Cor}^{\mathrm{c}} \mathrm{Cl}^{\mathrm{C}}\right)}{(\mathrm{mb})}$ & $\begin{array}{c}\text { Calcd } \\
\text { Totat }^{i} \\
(\mathrm{~g})\end{array}$ & 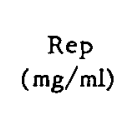 & $\begin{array}{l}\text { Calcd } \\
\text { Totat }{ }^{b} \\
(\mathrm{~g})\end{array}$ & $\underset{\substack{\mathrm{Rep} \\
(\mathrm{mg} / \mathrm{ml})}}{\cos }$ & $\begin{array}{c}\text { Calcd } \\
\text { Totat } \\
\text { (g) }\end{array}$ & & \\
\hline$E E-1-90^{k}$ & 0 & 0 & 0 & & 1.00 & 38.6 & 38.6 & 38.6 & 20.9 & 20.9 & 20.9 & 1.76 & 1.76 & 1.76 & $\mathrm{ND}^{l}$ & 0 & ND & 0 & ND & 0 & ND & 0 & ND & 0 & ND & 0 & ND & 0 & ND & 0 & 1.70 & 0.020 \\
\hline $\mathrm{EE}-1-191^{m}$ & 0 & 0 & 0 & & 1.00 & 38.3 & 38.3 & 38.3 & 24.3 & 24.3 & 24.3 & 1.67 & 1.67 & 1.67 & ND & 0 & $\mathrm{ND}$ & 0 & ND & 0 & ND & 0 & ND & 0 & ND & 0 & ND & 0 & ND & 0 & 1.30 & 0.050 \\
\hline $\mathrm{EE}-1-1.92^{n}$ & 33.3 & 0 & 0 & 1057 & 1.20 & 36.4 & 43.7 & 38.5 & 17.5 & 19.6 & 20.8 & 1.47 & 1.75 & 1.75 & ND & 0 & ND & 0 & ND & 0 & ND & 0 & (ND) & 0 & ND & 0 & ND & 0 & ND & 0 & 1.75 & 0.021 \\
\hline Reactor started up & 36.0 & 0 & & & & & & & & & & & & & & & & & & & & & & & & & & & & & & \\
\hline$E E-1-93$ & 54.8 & 56.0 & 0 & 1058 & 1.12 & 36.5 & 40.9 & 38.5 & 18.1 & 19.5 & 20.9 & 1.52 & 1.70 & 1.75 & ND & 0 & 0.006 & 0.01 & $\mathrm{ND}$ & 0 & ND & 0 & 0.011 & 0.01 & ND & 0 & ND & 0 & ND & 0 & 1.95 & 0.012 \\
\hline $\mathrm{EE}-1-94^{n}$ & 76.3 & 107.4 & 1.8 & 1059 & 1.14 & 34.6 & 39.4 & 38.5 & 18.4 & 20.1 & 20.9 & 1.43 & 1.63 & 1.75 & ND & 0 & 0.053 & 0.06 & ND & 0 & ND & 0 & ND & 0 & 0.040 & 0.05 & ND & 0 & ND & 0 & 2.05 & 0.023 \\
\hline EE-1-95 & 148.1 & 298.6 & 0 & 1057 & 1.17 & 34.8 & 40.7 & 38.5 & 18.4 & 20.3 & 21.0 & 1.47 & 1.71 & 1.75 & ND & 0 & 0.118 & 0.15 & ND & 0 & ND & 0 & 0.010 & 0.01 & 0.020 & 0.02 & ND & 0 & ND & 0 & 2.05 & 0.024 \\
\hline$E E-1-96^{n}$ & 172.6 & 358.3 & 2.1 & 1056 & 1.10 & 36.2 & 39.8 & 38.5 & 17.9 & 19.1 & 21.0 & 1.59 & 1.75 & 1.75 & ND & 0 & 0.144 & 0.17 & ND & 0 & 0.015 & 0.017 & 0.011 & 0.13 & 0.027 & 0.03 & ND & 0 & 0.005 & 0.01 & 1.90 & 0.014 \\
\hline EE-1-97 & 196.7 & 428.3 & 0 & 1055 & 1.12 & 33.3 & 37.3 & $38: 5$ & 19.0 & 20.6 & 21.1 & 1.43 & 1.59 & 1.75 & ND & 0 & 0.179 & 0.22 & $\mathrm{ND}$ & 0 & ND & 0 & 0.013 & 0.02 & 0.034 & 0.04 & ND & 0 & ND & 0 & 2.00 & 0.011 \\
\hline EE-1-98 & 244.6 & 562.8 & 0 & 1055 & 1.24 & 31.3 & 38.8 & 38.5 & 17.1 & 19.5 & 21.2 & 1.33 & 1.65 & 1.75 & ND & 0 & 0.189 & 0.27 & ND & 0 & 0.008 & 0.011 & 0.065 & 0.08 & 0.045 & 0.06 & 0.032 & 0.04 & 0.049 & 0.06 & 2.05 & 0.025 \\
\hline$E E-1-99$ & 316.6 & 766.7 & 0 & 1057 & 1.19 & 34.2 & 40.7 & 38.4 & 18.4 & 20.6 & 21.3 & 1.52 & 1.80 & 1.75 & ND & 0 & 0.371 & 0.50 & $\mathrm{ND}$ & 0 & ND & 0 & 0.003 & 0.01 & ND & 0 & 0.037 & 0.05 & ND & 0 & 2.05 & 0.024 \\
\hline EE-1-100 & 364.3 & 870.1 & 0 & 1058 & 1.18 & 34.5 & 40.7 & 38.4 & 18.7 & 20.8 & 21.5 & 1.36 & 1.60 & 1.75 & $\mathrm{ND}$ & 0 & 0.307 & 0.44 & ND & 0 & ND & 0 & 0.008 & 0.01 & 0.019 & 0.02 & 0.031 & 0.04 & 0.040 & 0.05 & 2.00 & 0.012 \\
\hline EE-1-101 & 412.4 & 1003.8 & 0 & 1058 & 1.21 & 322 & 39.0 & 38.4 & 18.6 & 21.1 & 21.5 & 1.59 & 1.93 & 1.75 & ND & 01 & 0.333 & 0.49 & ND & 0 & ND & 0 & 0.005 & 0.01 & 0.006 & 0.01 & 0.037 & 0.05 & ND & 0 & 2.10 & 0.010 \\
\hline $\mathrm{EE}-1-102^{n}$ & 484.4 & 1211.5 & 1.9 & 1058 & 1.22 & 31.2 & 38.1 & 38.4 & 18.1 & 20.6 & 21.5 & 1.59 & 1.94 & 1.75 & ND & 0 & 0.261 & 0.41 & ND & 0 & ND & 0 & 0.011 & 0.01 & 0.055 & 0.07 & 0.045 & 0.06 & ND & 0 & 2.10 & 0.010 \\
\hline EE-1-103 & 532.2 & 1334.2 & 0 & 1058 & 1.16 & 33.0 & 38.3 & 38.4 & 18.9 & 20.9 & 21.6 & 1.41 & 1.63 & 1.75 & ND & 0 & 0.364 & 0.53 & $\mathrm{ND}$ & 0 & 0.002 & 0.002 & 0.016 & 0.02 & 0.054 & 0.07 & 0.043 & 0.06 & ND & 0 & 1.95 & 0.013 \\
\hline EE-1-104 & 580.5 & 1463.8 & 0 & 1059 & 1.14 & 30.6 & 34.9 & 38.4 & 19.4 & 21.1 & 21.6 & 4.19 & 4.76 & 1.75 & $\mathrm{ND}$ & 0 & 0.469 & 0.65 & $\mathrm{ND}$ & 0 & ND & 0 & 0.015 & 0.02 & 0.031 & 0.04 & 0.051 & 0.07 & ND & 0 & 2.00 & 0.011 \\
\hline Reactor do wn & 630.2 & 1610.4 & & 1057 & & & & 38.4 & & & 21.6 & & & & & & & & & & & & & & & & & & & & & \\
\hline $\begin{array}{l}\text { Circulation pump } \\
\text { down }\end{array}$ & 630.3 & 1610.4 & & 1057 & & & & 38.4 & & & 21.6 & & & & & & & & & & & & & & & & & & & & & \\
\hline
\end{tabular}

$a_{\text {Where no values are }}$ given, either an analysis was not requested or the analy tical results were not reliable. $\epsilon_{\text {(Reported con centration) } x \text { (dilution factor). }}$.

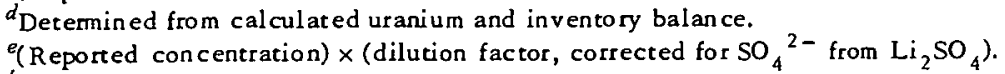

(Repored concentration) $\times$ (dilution factor, corrected for $\mathrm{SO}_{4}{ }_{4}^{2-}$ from $_{2} \mathrm{~L}_{2} \mathrm{SO}_{4}$ ).
'Determined from calaculated sulfate and inventory bal ance.
8 (Original concentration) $\times$ (calculculated uranium concentration at time of sample)

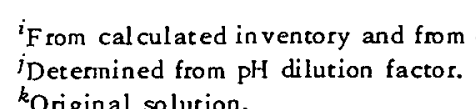

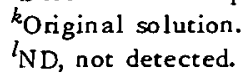


Table 15. Analyses of Samples from Loop Inventory During Enriched.Solution Operations, ${ }^{a}$ Loop FF

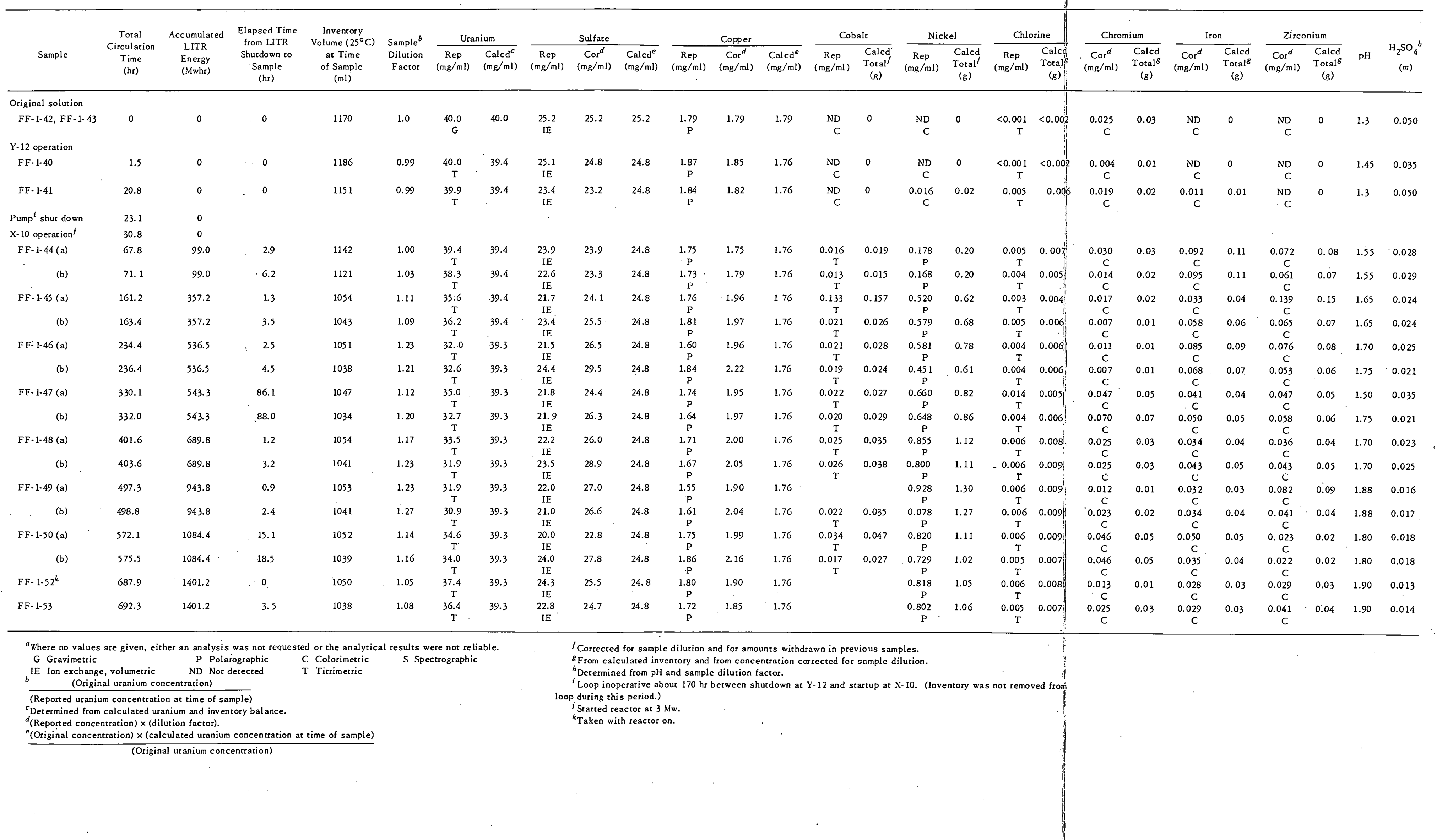




\begin{tabular}{|c|c|c|c|c|c|c|c|c|c|c|c|c|c|c|c|c|c|c|c|c|c|c|c|c|c|c|c|c|}
\hline \multirow[b]{2}{*}{ Sample } & \multirow{2}{*}{$\begin{array}{c}\text { Total } \\
\text { Circulation } \\
\text { Time } \\
\text { (hr) }\end{array}$} & \multirow{2}{*}{$\begin{array}{l}\text { Accumulated } \\
\text { LITR } \\
\text { Energy } \\
\text { (Mwhr) }\end{array}$} & \multirow{2}{*}{$\begin{array}{c}\text { Inventory } \\
\text { Volume at } \\
\text { Time of } \\
\text { Sample, } 25^{\circ} \mathrm{C} \\
\text { (ml) }\end{array}$} & \multirow[b]{2}{*}{$\begin{array}{l}\text { Lithium } \\
(\mathrm{mg} / \mathrm{ml})\end{array}$} & \multirow[b]{2}{*}{$\begin{array}{l}\text { Sample } \\
\text { Dilution } \\
\text { Factor }^{b}\end{array}$} & \multicolumn{3}{|c|}{ Uranium } & \multicolumn{3}{|c|}{ Sulfate } & \multicolumn{3}{|c|}{ Copper } & \multicolumn{2}{|c|}{ Chromium } & \multicolumn{2}{|c|}{ Nickel } & \multicolumn{2}{|c|}{ Chlorine } & \multicolumn{2}{|c|}{ Iron } & \multicolumn{2}{|c|}{ Zirconium } & \multicolumn{2}{|c|}{ Manganese } & \multirow[b]{2}{*}{$\mathrm{pH}$} & \multirow[b]{2}{*}{$\begin{array}{c}\mathrm{H}_{2} \mathrm{SO}_{4}{ }^{i} \\
(m)\end{array}$} \\
\hline & & & & & & $\begin{array}{l}\begin{array}{c}\text { Rep } \\
(\mathrm{mg} / \mathrm{ml})\end{array} \\
\text { (a) }\end{array}$ & $\begin{array}{c}\mathrm{Cor}^{d} \\
(\mathrm{mg} / \mathrm{m})\end{array}$ & $\begin{array}{c}\text { Calcd } \\
(\mathrm{mg} / \mathrm{ml})\end{array}$ & $\begin{array}{c}\text { Rep } \\
(\mathrm{mg} / \mathrm{ml})\end{array}$ & $\begin{array}{c}\mathrm{Cor}^{d} \\
(\mathrm{~m} / \mathrm{ml})\end{array}$ & 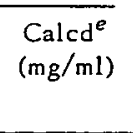 & $\begin{array}{c}\text { Rep } \\
(\mathrm{mg} / \mathrm{ml})\end{array}$ & $\begin{array}{c}\mathrm{Cor}^{\prime} \\
(\mathrm{mg} / \mathrm{ml})\end{array}$ & 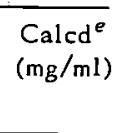 & $\begin{array}{c}\text { Rep } \\
(\mathrm{mg} / \mathrm{ml})\end{array}$ & $\begin{array}{l}\text { Calcd } \\
\text { Tocal } \\
\text { (g) }\end{array}$ & $\begin{array}{c}\operatorname{Rep} \\
(\mathrm{mg} / \mathrm{ml})\end{array}$ & $\begin{array}{c}\text { Calcd } \\
\text { Total } \\
\text { (g) }\end{array}$ & $\begin{array}{c}\text { Rep } \\
(\mathrm{mg} / \mathrm{ml})\end{array}$ & $\begin{array}{l}\text { Calcd } \\
\text { Total } \\
\text { (a) }\end{array}$ & $\overline{\substack{\operatorname{Rep} \\
(\mathrm{mg} / \mathrm{ml})}}$ & $\begin{array}{l}\text { Calcd } \\
\text { Total } \\
\text { (g) }\end{array}$ & $\begin{array}{c}\text { Rep } \\
(\mathrm{mg} / \mathrm{ml})\end{array}$ & $\begin{array}{c}\text { Calcd } \\
\text { Toral } \\
(\mathrm{B})\end{array}$ & $\begin{array}{c}\text { Rep } \\
(\mathrm{mg} / \mathrm{ml})\end{array}$ & $\begin{array}{c}\text { Calcd } \\
\text { Total } \\
\text { (g) }\end{array}$ & & \\
\hline $\begin{array}{l}\text { Priginal chare } \\
\text { GG-1-60 }\end{array}$ & 0 & 0 & 1039 & & & 39.8 & & & 23.5 & & & 1.75 & & & 0.320 & & ND & & ND & & ND & & ND & & & & 1.25 & 0.056 \\
\hline Takeup soluti & & & & & & & & & & & & & & & & & & & & & & & & & & & & \\
\hline$G G-1-61$ & 0 & 0 & & & & 39.4 & & & 23.5 & & & 1.81 & & & 0.482 & & ND & & ND & & $\mathrm{ND}$ & & ND & & & & 1.25 & 0.056 \\
\hline$G G-1-62^{i}$ & 45.2 & 0 & 1039 & & 1.14 & 34.9 & & 39.8 & 22.7 & 25.8 & 23.5 & 1.74 & 1.99 & 1.75 & 0.182 & 0.216 & ND & 0 & ND & 0 & ND & 0 & $\mathrm{ND}$ & 0 & & & 1.30 & 0.057 \\
\hline GG-1-63i & 47.2 & 0 & 1015 & & 1.10 & 36.1 & & 39.8 & 22.0 & 24.2 & 23.5 & 1.63 & 1.79 & 1.75 & 0.133 & 0.149 & ND & 0 & ND & 0 & ND & 0 & $\mathrm{ND}$ & 0 & & & 1.30 & 0.055 \\
\hline GG-1-64 & 77.8 & 5.2 & 1035 & & 0.98 & 40.8 & & 39.8 & 23.4 & 22.9 & 23.5 & 1.94 & 1.90 & 1.75 & 0.089 & 0.090 & 0.058 & 0.06 & $<0.001$ & $<0.001$ & 0.024 & 0.02 & 0.039 & 0.04 & & & 1.30 & 0.049 \\
\hline$G G-1-65$ & 80.1 & 12.2 & 1016 & & 0.97 & 40.9 & & 39.8 & 23.2 & 22.5 & 23.5 & 1.78 & 1.72 & 1.75 & 0.053 & 0.052 & 0.103 & 0.10 & $<0.001$ & $<0.001$ & 0.032 & 0.03 & 0.037 & 0.04 & & & 1.30 & 0.049 \\
\hline GG-1-66 & 83.1 & 21.4 & 1001 & & 1.10 & 36.3 & & 39.8 & 21.4 & 23.6 & 23.5 & 1.68 & 1.85 & 1.75 & 0.035 & 0.039 & 0.082 & 0.09 & $<0.001$ & $<0.001$ & 0.018 & 0.02 & 0.042 & 0.05 & & & 1.45 & 0.039 \\
\hline$G G-1 \cdot 67$ & 85.3 & 27.9 & 986 & & 1.11 & 35.7 & & 39.8 & 21.4 & 23.7 & 23.5 & 1.57 & 1.75 & 1.75 & 0.038 & 0.042 & 0.091 & 0.10 & $<0.001$ & $<0.001$ & 0.023 & 0.03 & 0.037 & 0.04 & & & 1.50 & 0.036 \\
\hline$G G-1-68$ & 98.6 & 67.6 & 1033 & & 1.22 & 32.7 & & 39.8 & 20.9 & 25.5 & 23.5 & 1.72 & 2.10 & 1.75 & 0.032 & 0.040 & 0.188 & 0.24 & $<0.001$ & $<0.001$ & 0.012 & 0.02 & 0.029 & 0.04 & & & 1.50 & 0.039 \\
\hline$G G-1-69$ & 120.6 & 120.6 & 1032 & & 1.19 & 33.3 & & 39.8 & 22.9 & 27.2 & 23.5 & 1.55 & 1.84 & 1.74 & 0.028 & 0.034 & 0.263 & 0.33 & $<0.001$ & $<0.001$ & 0.014 & 0.02 & 0.027 & 0.03 & & & 1.50 & 0.038 \\
\hline$G G-1-70$ & 169.2 & 253.6 & 1034 & & 1.14 & 34.9 & & 39.7 & 21.8 & 24.8 & 23.5 & 1.62 & 1.85 & 1.74 & 0.012 & 0.014 & 0.470 & 0.57 & $<0.001$ & $<0.001$ & 0.029 & 0.03 & 0.073 & 0.09 & & & 1.60 & 0.029 \\
\hline$G G-1 \cdot 71$ & 190.8 & 309.2 & 1036 & & 1.17 & 34.2 & & 39.7 & 20.0 & 23.4 & 23.5 & 1.79 & 2.09 & 1.74 & 0.011 & 0.013 & 0.440 & 0.56 & $<0.001$ & $<0.001$ & 0.025 & 0.03 & 0.057 & 0.07 & & & 1.60 & 0.029 \\
\hline$G G-1-72$ & 239.5 & 427.5 & 1032 & & 1.27 & 31.1 & & 39.7 & 20.6 & 26.1 & 23.5 & 1.46 & 1.86 & 1.74 & 0.001 & 0.001 & 0.746 & 1.01 & $<0.001$ & $<0.001$ & 0.014 & 0.02 & 0.043 & 0.06 & & & 1.60 & 0.032 \\
\hline$G G=1-73$ & 269.7 & 518.1 & 1032 & & 1.12 & 35.5 & & 39.7 & 21.6 & 24.2 & 23.5 & 1.41 & 1.58 & 1.74 & 0.001 & 0.001 & 0.520 & 0.66 & $<0.001$ & $<0.001$ & 0.027 & 0.03 & 0.037 & 0.04 & & & 1.65 & 0.025 \\
\hline GG-1-74 & 337.3 & 719.8 & 1032 & & 1.16 & 34.1 & & 39.7 & 22.0 & 25.5 & 23.5 & 1.51 & 1.75 & 1.74 & 0.026 & 0.031 & 0.854 & 1.09 & $<0.001$ & $<0.001$ & 0.005 & 0.01 & 0.033 & 0.04 & & & 1.70 & 0.023 \\
\hline GG-1.-75 & 365.3 & 774.7 & 1034 & & 1.20 & 33.1 & & 39.6 & 22.9 & 27.5 & 23.4 & 1.79 & 2.15 & 1.74 & 0.025 & 0.031 & 0.684 & 0.93 & $<0.001$ & $<0.001$ & 0.005 & 0.01 & 0.032 & 0.04 & & & 1.70 & 0.024 \\
\hline GG-1-76 & 433.1 & 949.6 & 1037 & & 1.24 & 31.9 & & 39.6 & 20.9 & 25.9 & 23.4 & 1.39 & 1.72 & 1.73 & 0.005 & 0.006 & 0.698 & 1.00 & $<0.001$ & $<0.001$ & 0.007 & 0.01 & 0.017 & 0.02 & & & 1.70 & 0.025 \\
\hline GG-1.77 & 504.9 & 1156.6 & 1038 & & 1.19 & 33.4 & & 39.5 & 21.8 & 25.9 & 23.4 & 1.35 & 1.60 & 1.73 & 0.006 & 0.007 & 0.791 & 1.10 & $<0.001$ & $<0.001$ & 0.017 & 0.02 & 0.031 & 0.04 & & & 1.70 & 0.024 \\
\hline GG-1-178 & 553.0 & 1289.3 & 1040 & & 1.28 & 30.8 & & 39.5 & 20.4 & 26.1 & 23.4 & 1.52 & 1.94 & 1.73 & 0.001 & 0.001 & 0.984 & 1.45 & $<0.001$ & $<0.001$ & 0.015 & 0.02 & 0.040 & 0.05 & & & 1.70 & 0.026 \\
\hline GG-1-79 & 603.5 & 1567.8 & 1037 & 0.79 & 1.09 & 34.9 & 38.0 & 39.5 & 28.6 & 25.2 & 23.4 & 1.44 & 1.57 & 1.73 & 0.010 & 0.011 & 0.905 & 1.18 & $<0.001$ & $<0.001$ & 0.020 & 0.02 & 0.028 & 0.03 & & & 1.70 & 0.022 \\
\hline$G G-1-80^{k}$ & 678.4 & 1638.0 & 1034 & 1.24 & 1.15 & 33.6 & 38.6 & 39.5 & 30.9 & 25.7 & 23.4 & 1.41 & 1.62 & 1.73 & 0.005 & 0.006 & 0.833 & 1.17 & $<0.001$ & $<0.001$ & 0.017 & 0.02 & 0.020 & 0.02 & & & 1.75 & 0.020 \\
\hline$G G-1-81^{k}$ & 721.0 & 1802.2 & 1034 & 1.84 & 1.24 & 30.6 & 37.9 & 39.5 & 35.0 & 27.6 & 23.4 & 1.34 & 1.66 & 1.73 & 0.001 & 0.001 & 0.939 & 1.40 & $<0.001$ & $<0.001$ & 0.021 & 0.03 & 0.050 & 0.06 & & & 1.85 & 0.017 \\
\hline$G G-1-82^{k}$ & 769.0 & 1949.2 & 1033 & 1.78 & 1.23 & 33.8 & 41.6 & 39.5 & 33.4 & 25.9 & 23.4 & 1.32 & 1.62 & 1.73 & 0.001 & 0.001 & 1.046 & 1.55 & $<0.001$ & $<0.001$ & 0.021 & 0.03 & 0.030 & 0.04 & & & 1.88 & 0.016 \\
\hline$G G-1-83^{k}$ & 842.5 & 2155.9 & 1034 & 1.36 & 1.17 & 33.3 & 39.0 & 39.5 & 30.2 & 24.3 & 23.4 & 1.39 & 1.62 & 1.73 & 0.005 & 0.001 & 0.749 & 1.15 & $<0.001$ & $<0.001$ & 0.021 & 0.03 & 0.034 & 0.04 & 0.151 & 0.18 & 2.15 & 0.008 \\
\hline GG-1-84 ${ }^{k}$ & 894.2 & 2268.0 & 1035 & 1.86 & 1.24 & 30.4 & 37.7 & 39.5 & 34.5 & 26.7 & 23.4 & 1.34 & 1.66 & 1.73 & 0.001 & 0.001 & 0.923 & 1.45 & $<0.001$ & $<0.001$ & 0.018 & 0.02 & 0.033 & 0.04 & 0.182 & 0.24 & 1.95 & 0.014 \\
\hline GG-1-85 $l$ & 936.6 & 2394.1 & 1034 & 0.28 & 1.42 & 29.6 & 42.0 & 39.5 & 23.8 & 31.1 & 23.4 & 1.35 & 1.91 & 1.73 & 0.001 & 0.001 & 0.929 & 1.65 & $<0.001$ & $<0.001$ & 0.049 & 0.07 & 0.032 & 0.05 & 0.140 & 0.21 & 2.00 & 0.014 \\
\hline$G G=1-86^{l}$ & 1009.5 & 2579.6 & 1036 & 0.15 & 1.19 & 38.9 & 46.3 & 39.5 & 22.9 & 26.0 & 23.4 & 1.41 & 1.68 & 1.73 & 0.001 & 0.001 & 0.954 & 1.49 & $<0.001$ & $<0.001$ & 0.014 & 0.02 & 0.020 & 0.03 & 0.133 & 0.18 & 1.90 & 0.015 \\
\hline$G G-1-87^{l}$ & 1057.8 & 2676.4 & 1035 & 0.13 & 1.16 & 34.4 & 39.9 & 39.5 & 22.7 & 25.3 & 23.4 & 1.51 & 1.76 & 1.73 & 0.001 & 0.001 & 1.572 & 1.64 & $<0.001$ & $<0.001$ & 0.015 & 0.02 & 0.031 & 0.04 & 0.168 & 0.22 & 1.70 & 0.023 \\
\hline ind of run & 1063.7 & 2692.3 & 1035 & & & & & & & & & & & & & & & & & & & & & & & & & \\
\hline
\end{tabular}

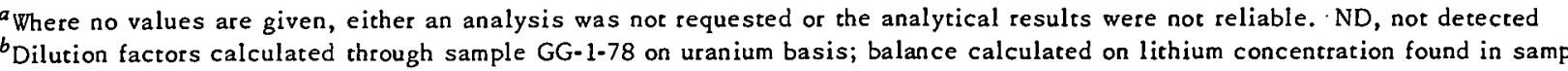

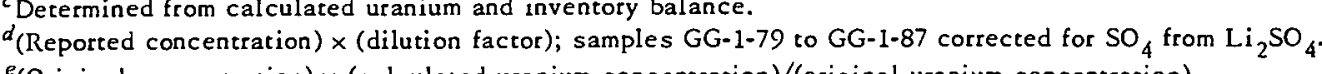

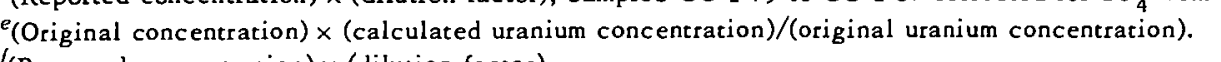

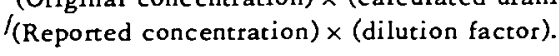

${ }_{b}^{8}$ (Reported concentration $) \times$ (diluturion factor $) \times$ (inventory volume)

Determined from $\mathrm{pH}$ and directed for sample dilution and amounts withdrawn in previous samples) $\times$ (inventory volume). Sample taken with reactor down.
Wash water

Wash water concained $\mathrm{Li}_{2} \mathrm{SO}_{4}$ at $0.688 \mathrm{M}$.
Wash water contained $\mathrm{Li}_{2} \mathrm{SO}_{4}$ at $0.068 \mathrm{M}$. 


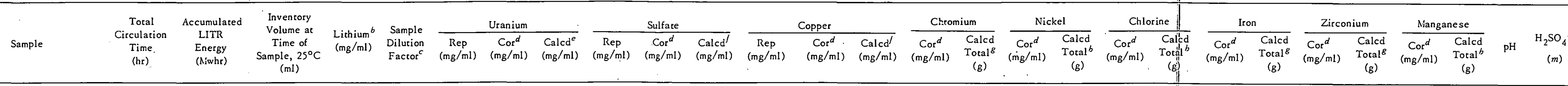

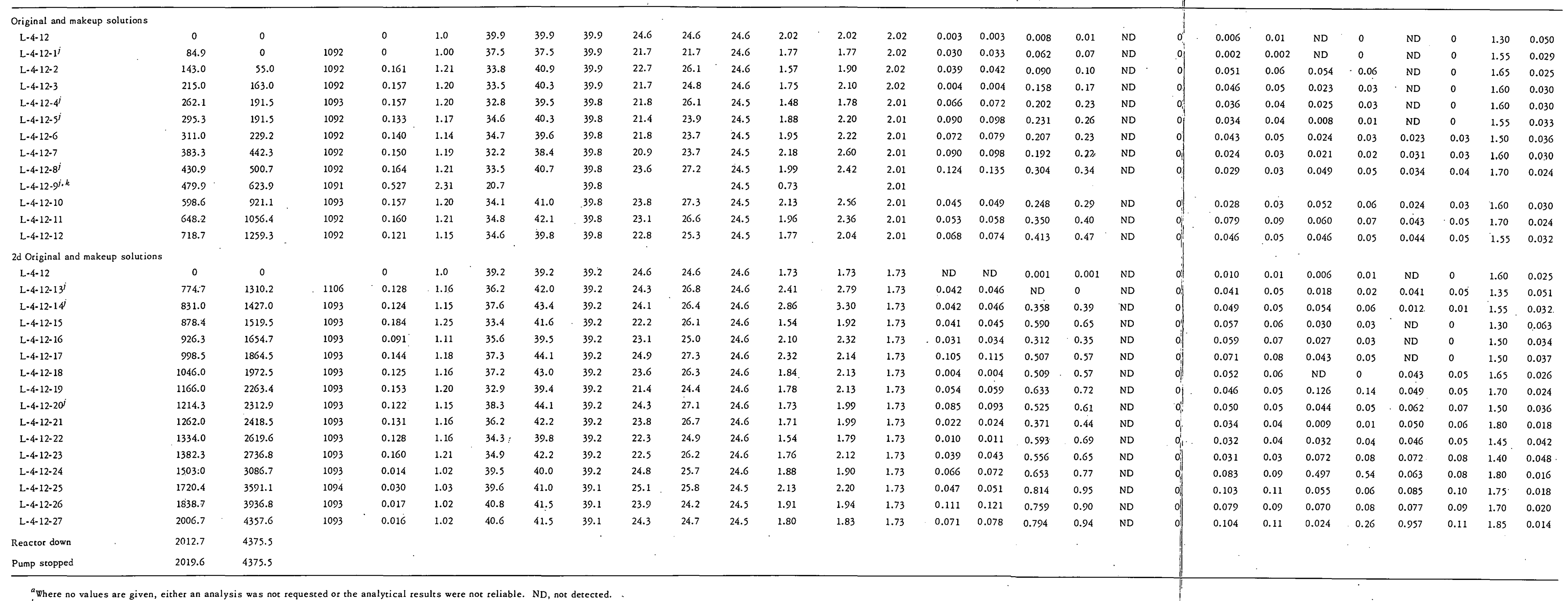


Table 18. Analyses of Samples from Loop Inventory During Enriched-Solution Operation, ${ }^{a}$ Loop L-4-13

\begin{tabular}{|c|c|c|c|c|c|c|c|c|c|c|c|c|c|c|c|c|c|c|c|c|c|c|c|c|c|c|c|c|c|c|c|}
\hline \multirow[b]{2}{*}{ Sample } & \multirow{2}{*}{$\begin{array}{c}\text { Total } \\
\text { Circulation } \\
\text { Time } \\
\text { (hr) }\end{array}$} & \multirow{2}{*}{$\begin{array}{l}\text { Accumulated } \\
\text { LIrR } \\
\text { Energy } \\
\text { (Mwhr) }\end{array}$} & \multirow{2}{*}{$\begin{array}{c}\text { Inventory } \\
\text { Volume at } \\
\text { Time of } \\
\text { Sample, 25 } 25^{\circ} \mathrm{C} \\
(\mathrm{ml})\end{array}$} & \multirow[b]{2}{*}{$\begin{array}{l}\operatorname{Lithium}^{b} \\
(\mathrm{mg} / \mathrm{ml}\end{array}$} & \multirow{2}{*}{$\begin{array}{l}\text { Sample } \\
\text { Diflution } \\
\text { Factor }\end{array}$} & \multicolumn{3}{|c|}{ Uranium } & \multicolumn{3}{|c|}{ Sulfate } & \multicolumn{3}{|c|}{ Copper } & \multicolumn{2}{|c|}{ Chromium } & \multicolumn{2}{|c|}{ Nickel } & \multicolumn{2}{|c|}{ Chlorine } & \multicolumn{2}{|c|}{ Iron } & \multicolumn{2}{|c|}{ Zirconium } & \multicolumn{2}{|c|}{ Manganese } & \multirow[b]{2}{*}{$\mathrm{pH}^{i}$} & \multirow[b]{2}{*}{$\begin{array}{l}\text { Fluorine } \\
\text { Reported } \\
(\mathrm{mg} / \mathrm{ml})\end{array}$} & \\
\hline & & & & & & $\begin{array}{c}\text { Rep } \\
\left(\mathrm{mg}_{\mathrm{g} / \mathrm{ml}}\right)\end{array}$ & 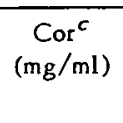 & $\begin{array}{l}\text { Calcd } \\
\left(\mathrm{Cag}_{\mathrm{g} / \mathrm{m} / \mathrm{m}}\right.\end{array}$ & $\begin{array}{c}\text { Rep } \\
\left(\mathrm{mg}_{\mathrm{g} / \mathrm{ml})}\right.\end{array}$ & $\begin{array}{c}\operatorname{Cor}^{e} \\
\left(\mathrm{mg}_{\mathrm{g} / \mathrm{ml})}\right)\end{array}$ & 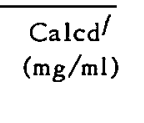 & $\begin{array}{c}\text { Rep } \\
\left(\mathrm{me}_{\mathrm{B} / \mathrm{ml})}\right.\end{array}$ & 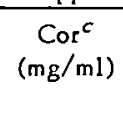 & $\begin{array}{c}\text { Calcd } \\
\left(\mathrm{mg} / \mathrm{ml}^{8}\right)\end{array}$ & $\begin{array}{c}\operatorname{cep}_{(\mathrm{Rep}} \\
(\mathrm{mg} / \mathrm{ml})\end{array}$ & $\begin{array}{c}\text { Calcd } \\
\text { Totat } \\
(\mathrm{g})^{2}\end{array}$ & $\begin{array}{c}\text { Rep } \\
(\mathrm{mg} / \mathrm{ml})\end{array}$ & $\begin{array}{c}\text { Calcd } \\
\text { Toati } \\
(\mathrm{g})\end{array}$ & $\begin{array}{c}\mathrm{Rep} \\
(\mathrm{m} / \mathrm{ml})\end{array}$ & $\begin{array}{c}\text { Calcd } \\
\text { Totali } \\
(\mathrm{g})\end{array}$ & $\begin{array}{c}\text { Rep } \\
(\mathrm{mg} / \mathrm{ml})\end{array}$ & $\begin{array}{l}\text { Calcd } \\
\text { Total } \\
\text { (g) }\end{array}$ & $\begin{array}{c}\text { Rep } \\
(\mathrm{mg} / \mathrm{ml})\end{array}$ & $\begin{array}{l}\text { Calcd } \\
\text { Total } \\
\text { Tot) }\end{array}$ & $\begin{array}{c}\text { Rep } \\
(\mathrm{mg} / \mathrm{m})\end{array}$ & $\begin{array}{l}\text { Calcd } \\
\text { Total } \\
\text { Total } \\
\text { (g) }\end{array}$ & & & $\overline{\text { Rep }}$ & $\frac{\mathrm{D}_{2} \mathrm{SO}_{4} \mathrm{CA}}{\mathrm{Cor}^{\mathrm{c}} \mathrm{c}}$ & 4) \\
\hline inal charge & 0 & 0 & 1097 & ND & & 41.3 & & & 22.0 & & & 2.15 & & & 0.012 & & 0.008 & & $<0.001$ & & 0.030 & & & & & & 1.40 & & 0.020 & & \\
\hline keup solution & 0 & 0 & & ND & & 41.3 & & & 24.0 & & & 1.95 & & & 0.010 & & 0.010 & & $<0.001$ & & 0.024 & & & & & & 1.05 & 0.003 & 0.044 & & \\
\hline$-4-13-1^{l}$ & 71.5 & 0 & 1098 & 0.13 & 1.17 & 39.4 & 46.0 & 41.2 & 21.5 & 24.0 & 22.0 & 2.14 & 2.50 & 2.15 & & & 0.041 & 0.05 & & & 0.028 & 0.04 & & & & & 1.35 & & & & 0.019 \\
\hline -4-13-2 & 114.3 & 113.5 & 1099 & 0.08 & 1.09 & 36.3 & 39.5 & 41.2 & 20.0 & 21.2 & 22.0 & 1.70 & 1.85 & 2.15 & 0.072 & 0.086 & 0.101 & 0.12 & & & 0.155 & 0.19 & 0.125 & 0.15 & & & 1.70 & & & & 0.018 \\
\hline$-4 \cdot-13-3$ & 185.7 & 309.8 & 1101 & 0.10 & 1.12 & & & 41.2 & & & 22.0 & 1.76 & 1.98 & 2.15 & & & 0.199 & 0.25 & & & & & & & & & & & 0.020 & 0.023 & 0.016 \\
\hline -4-4-13-4 & 233.7 & 424.2 & 1096 & 0.12 & 1.14 & 38.1 & 43.5 & 41.2 & 20.0 & 22.0 & 22.0 & 1.85 & 2.11 & 2.15 & 0.168 & 0.211 & 0.302 & 0.38 & & & 0.134 & 0.17 & 0.053 & 0.07 & 0.038 & 0.05 & 1.65 & & & & 0.014 \\
\hline$-4-13-5$ & 282.4 & 554.2 & 1097 & 0.11 & 1.14 & 36.1 & 41.1 & 41.1 & 19.8 & 21.7 & 22.1 & 1.70 & 1.93 & 2.15 & 0.070 & 0.087 & 0.333 & 0.42 & & & 0.033 & 0.04 & 0.124 & 0.16 & 0.023 & 0.03 & 1.70 & & & & 0.014 \\
\hline -4-413-6 & 353.9 & 722.9 & 1091 & 0.13 & 1.16 & & & 41.1 & & & 22.1 & & & 2.15 & & & 0.423 & 0.56 & & & & & & & & & & & 0.019 & 0.022 & 0.012 \\
\hline$-4 \cdot 13-7^{l}$ & 401.8 & 777.7 & 1097 & 0.14 & 1.17 & 35.3 & 41.5 & 41.1 & 20.6 & 23.1 & 22.2 & 1.79 & 2.10 & 2.15 & 0.276 & 0.355 & 0.512 & 0.69 & & & 0.042 & 0.05 & 0.121 & 0.16 & 0.039 & 0.05 & 1.75 & & & & 0.011 \\
\hline$-4-13-8$ & 450.0 & 886.8 & 1097 & 0.14 & 1.17 & 36.2 & 42.4 & 41.1 & 22.3 & 25.0 & 22.2 & 1.81 & 2.12 & 2.15 & 0.146 & 0.188 & 0.388 & 0.55 & & & 0.036 & 0.05 & 0.092 & 0.12 & 0.037 & 0.05 & 1.60 & & & & 0.014 \\
\hline$-4-13-9$ & 521.8 & 1095.7 & 1097 & 0.12 & 1.15 & & & 41.1 & & & 22.3 & & & 2.15 & & & 0.416 & 0.58 & & & & & & & & & & & 0.019 & 0.022 & 0.014 \\
\hline -4-13-10 & 617.9 & 1274.9 & 1101 & 0.11 & 1.14 & 36.1 & 41.1 & 41.0 & 21.2 & 23.2 & 22.2 & 1.59 & 1.81 & 2.14 & 0.091 & 0.114 & 0.475 & 0.67 & & & 0.039 & 0.05 & 0.078 & 0.10 & 0.037 & 0.05 & 1.65 & 0.011 & & & 0.014 \\
\hline$-4-13-11$ & 690.3 & 1480.7 & 1098 & 0.13 & 1.16 & & & 41.0 & & & 22.3 & & & 2.14 & & & & 0.81 & & & & & & & & & & & 0.021 & 0.024 & 0.013 \\
\hline$-4-413-12$ & & & & 0.13 & 1.17 & 39.3 & 45.8 & 41.0 & 22.1 & 24.7 & 22.3 & 1.77 & 2.07 & 2.14 & 0.074 & 0.095 & 0.661 & 0.95 & & & 0.060 & 0.08 & 0.076 & 0.10 & 0.032 & 0.05 & 1.60 & & & & 0.013 \\
\hline$-4-43-13$ & 785.9 & & 1098 & 0.12 & 1.15 & 38.6 & 44.4 & 41.0 & 20 & 23.1 & 22.4 & 1.62 & 1.86 & 2.14 & 0.117 & 0.148 & 0.581 & 0.87 & & & & & 0.120 & 0.15 & 0.032 & 0.05 & 1.65 & & & & 0.014 \\
\hline$-4-13-11$ & 857.9 & 1947.0 & 1097 & 0.12 & 1.15 & 35.3 & 40.6 & 41.1 & 20.9 & 23.1 & 22.4 & 1.58 & 1.82 & 2.14 & & & 0.547 & 0.81 & & & & & & & & & & & 0.021 & 0.024 & 0.015 \\
\hline$-4 \cdot 13-15$ & 931.2 & 2054.7 & 1109 & 0.12 & 1.15 & 36.5 & 42.0 & 40.6 & 21.0 & 23.2 & 22.2 & 1.53 & 1.77 & 2.12 & 0.089 & 0.114 & 0.543 & 0.86 & & & 0.143 & 0.18 & 0.014 & 0.18 & 0.057 & 0.08 & & & & & 0.015 \\
\hline$-4-43-16$ & 1025.7 & & 1098 & 0.12 & 1.15 & 36.5 & 42.1 & 40.6 & 20.5 & 22.6 & 22.3 & 1.57 & 1.81 & 2.12 & 0.098 & 0.124 & 0.514 & 0.84 & & & 0.082 & 0.10 & ND & 0 & ND & 0 & & & & & 0.017 \\
\hline$-4-43-17$ & 1027.9 & 2327.9 & 1078 & 0.22 & 1.30 & & & 40.6 & & & 22.3 & & & 2.12 & & & & & & & & & & & & & 1.65 & & 0.016 & 0.021 & \\
\hline
\end{tabular}

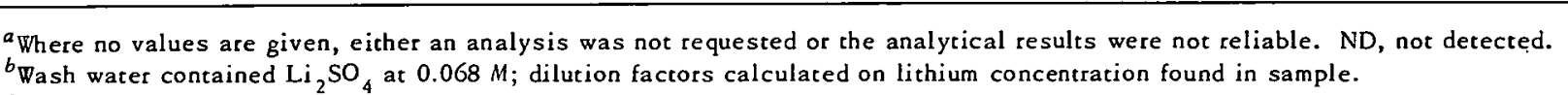

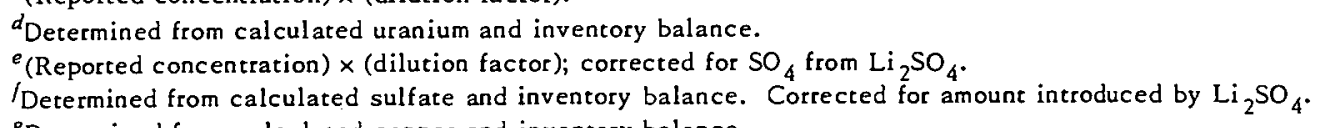

(Reported concentration) $\times$ (diliturion factor) $\times$ (inventory volume).
(Reported concentration corrected for sample dilution and amounts withdrawn in previous samples) $\times$ (inventory volume).

Obtained with $\mathrm{PH}$ meter cal ibrated with $\mathrm{H}_{2} \mathrm{O}$ solutions.

${ }^{k}$ Acid remaining after stoichiomem
ISample taken with reactor down. 
Table 19. Analyses of Samples from Loop Inventory During Enriched.Solution Operation, ${ }^{a}$ Loop L-4-18

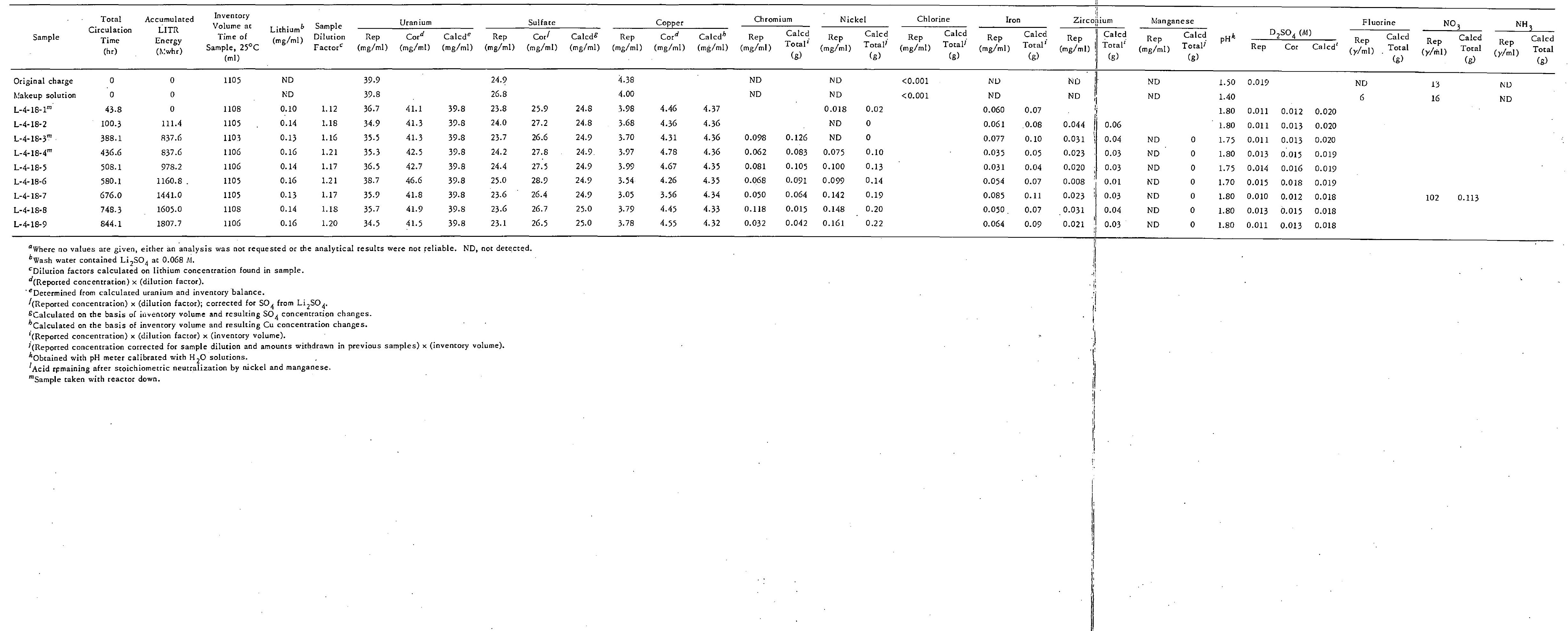


correspond to given amounts of nickel or manganese in solution (calculated as described in Sec 4.1) are also shown.

As will be brought out in the discussion, the amount of excess $\mathrm{H}_{2} \mathrm{SO}_{4}$ in solution was an important factor in determining the steel corrosion during exposure to fissioning uranyl sulfate solutions. The results of measurements and of estimates of free $\mathrm{H}_{2} \mathrm{SO}_{4}$ in the different experiments are shown graphically in Fig. 84. The data illustrated for experiments $L-4-13$ and $L-4-18$ were obtained from analytical determinations of free acid. For the other experiments in which direct free-acid analyses were not made, the freeacid values were estimated from the results of $\mathrm{pH}$ measurements. For these estimates, the relationship between $\mathrm{pH}$ and excess $\mathrm{H}_{2} \mathrm{SO}_{4}$ in solutions containing $0.17 \mathrm{~m} \mathrm{UO}_{2} \mathrm{SO}_{4}$ and $0.03 \mathrm{~m} \mathrm{CuSO}_{4}$ was determined in control experiments (Fig. 22). Additional control experiments showed that dilution of the control solution with water or dilute $\mathrm{Li}_{2} \mathrm{SO}_{4}$ solution to about the extent encountered in sampling resulted in $\mathrm{pH}$ changes which were in accord with those expected from the dilution of the excess acid. Therefore the appropriate dilution factors and the relationship shown in Fig. 22 were employed to convert $\mathrm{pH}$ readings into free-acid concentrations.

\subsection{In-Pile Operation, Oxygen Consumption}

The results of oxygen consumption measurements during radiation exposure are shown in Figs. 23-29 in plots of calculated rates of consumption on steel vs megawatt-hours of LITR energy accumulated during exposure. Each datum was obtained during periods in which the reactor operated at the 3-Mw power level (the usual level) and in which the rates of pressure loss were essentially constant for about $20 \mathrm{hr}$ or more. The plotted times are midpoints of such periods. The consumption rates are in units of volume of oxygen per $3 \mathrm{Mwhr}$. Also shown in each figure are values for the average consumption rates on the zirconium and titanium alloys determined from weight data. The steel rates were obtained by reducing the observed consumption rates by these listed amounts. Values are also shown in each figure for the relationships between oxygen consumption rates and steel corrosion rates in mils per year when it is assumed in one case that all steel surfaces in contact with high-temperature solution corroded uniformly, and in another case that only the steel surfaces in the core consumed oxygen. The actual distribution of the corrosion in a loop will be considered in the discussion section.

Data for the total amounts of oxygen consumed during the in-pile exposures are listed in Tables 20-26. The corresponding steel penetration values (calculated as described in Sec 4.1) are also listed. These oxygen consumption results are shown graphically and compared with the nickel and manganese results in Figs. 15-21 as functions of total times at operating temperature. The final oxygen value in each of these plots was also corrected for the amount of oxygen consumed by zirconium and titanium alloys by the factors listed in Figs. 23-29, and the points, representing the corrected overall corrosion penetration of stainless steel determined from oxygen data, are shown for comparison. Similarly corrected, total amounts of oxygen consumed by steel surfaces are shown vs megawatthours of LITR energy in Fig. 30. Data from a previously reported experiment, $\mathrm{L}-4-11,{ }^{3}$ are also illustrated in Fig. 30. These data will be employed in the later discussions of the steel corrosion results of these experiments. 


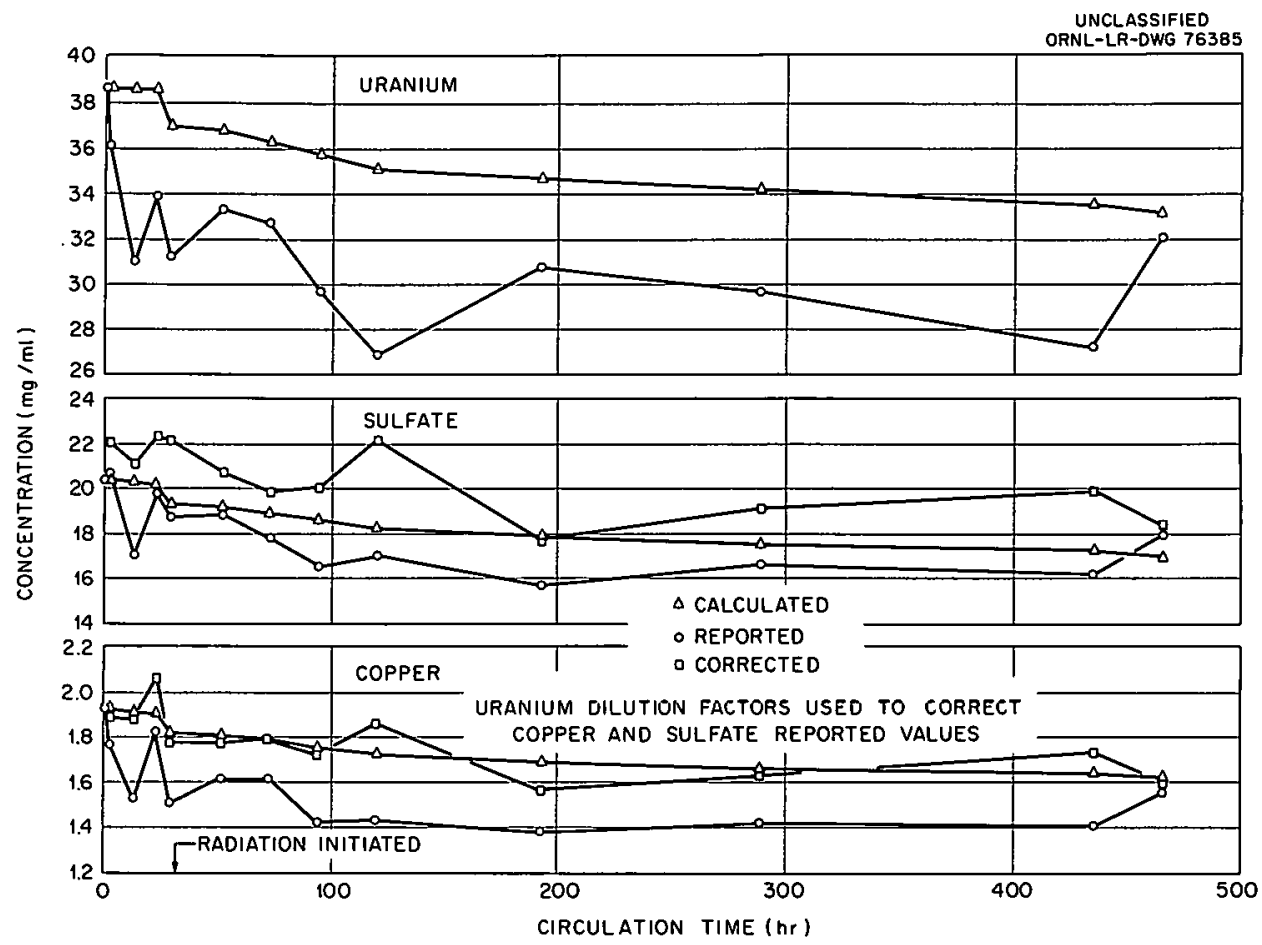

Fig. 8. Concentration of Uranium, Sulfate, and Copper in Solution Samples, Loop DD.

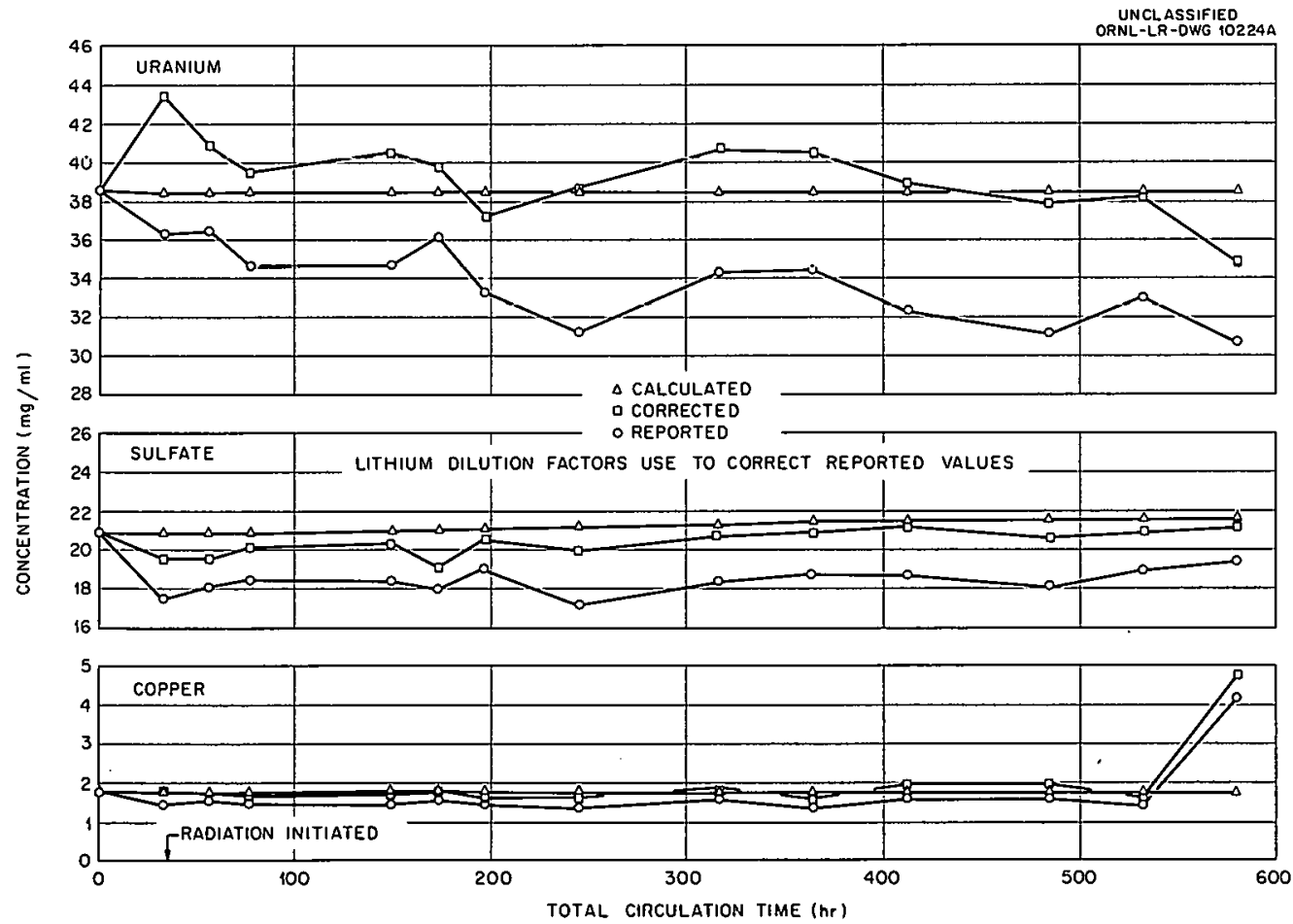

Fig. 9. Concentrotion of Uranium, Sulfate, and Copper in Solution Samples, Loop EE. 
- calculated

- reported (CORREcted for sample dilution

$\triangle$ REPORTED

URANIUM DILUTION FACTORS USED TO CORRECT COPPER AND SULFATE REPORTED VALUES

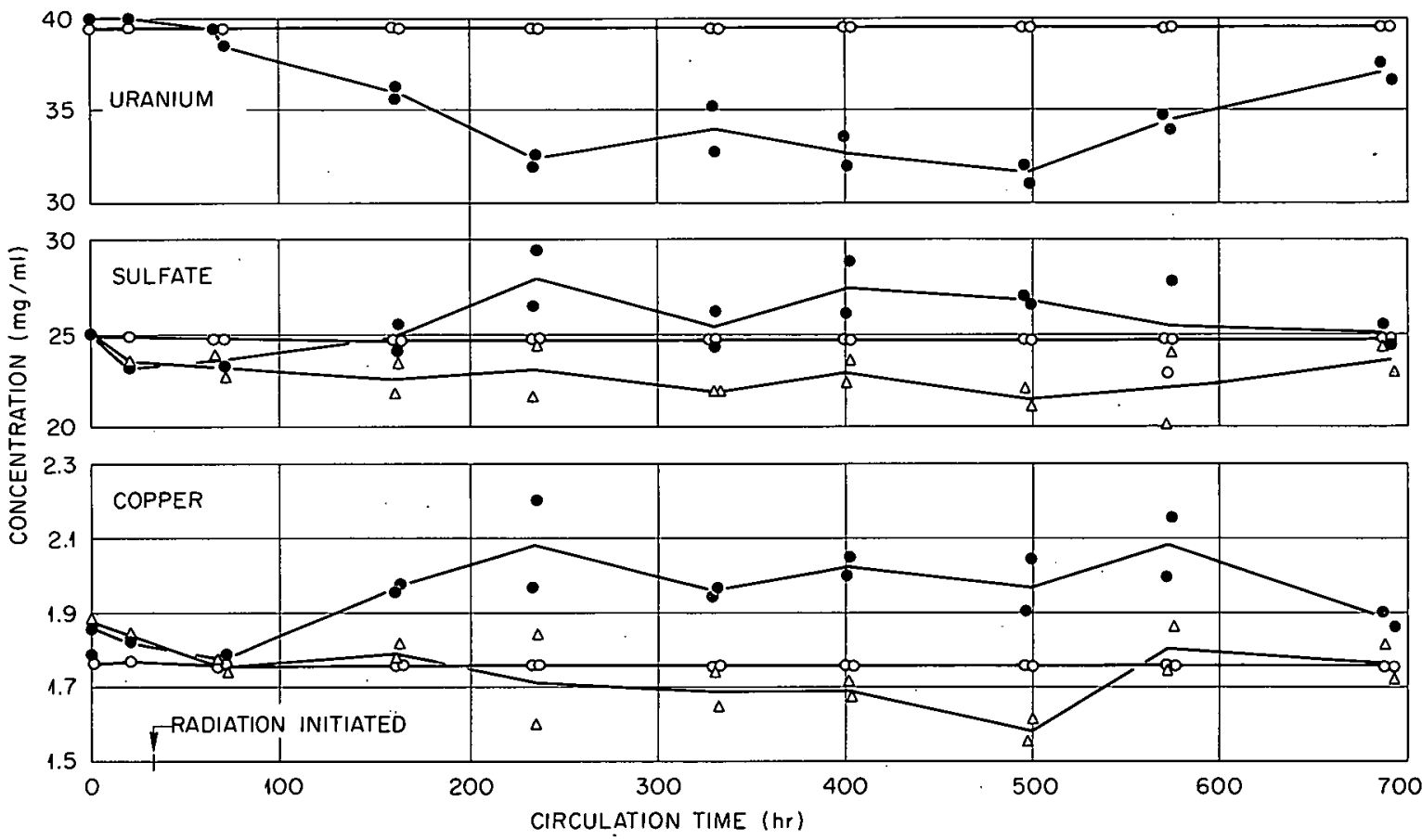

Fig. 10. Concentration of Uranium, Sulfate, and Copper in Solution Samples, Loop.FF.

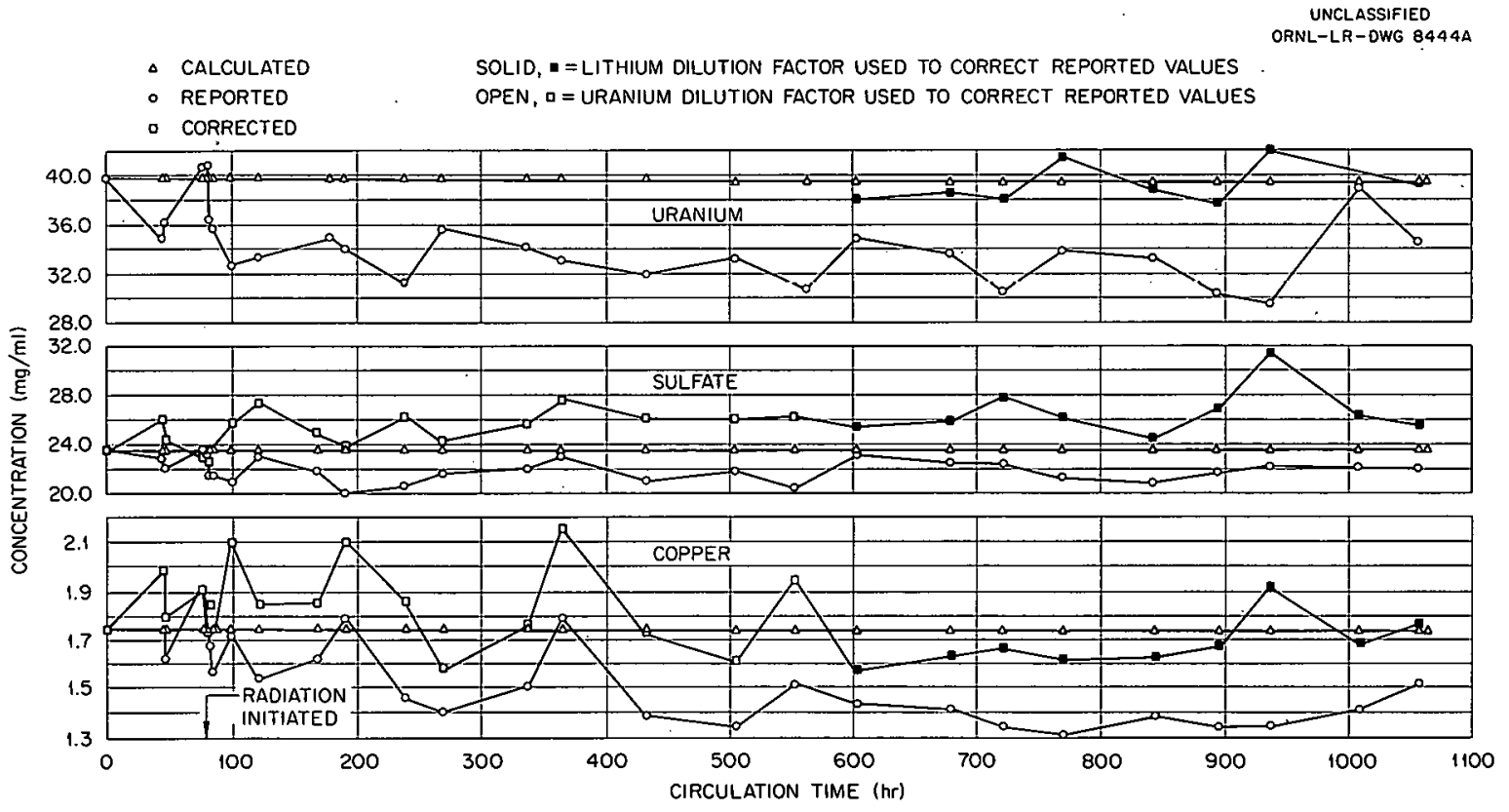

Fig. 11. Concentration of Uranium, Sulfate, and Copper in Solution Samples, Loop GG. 


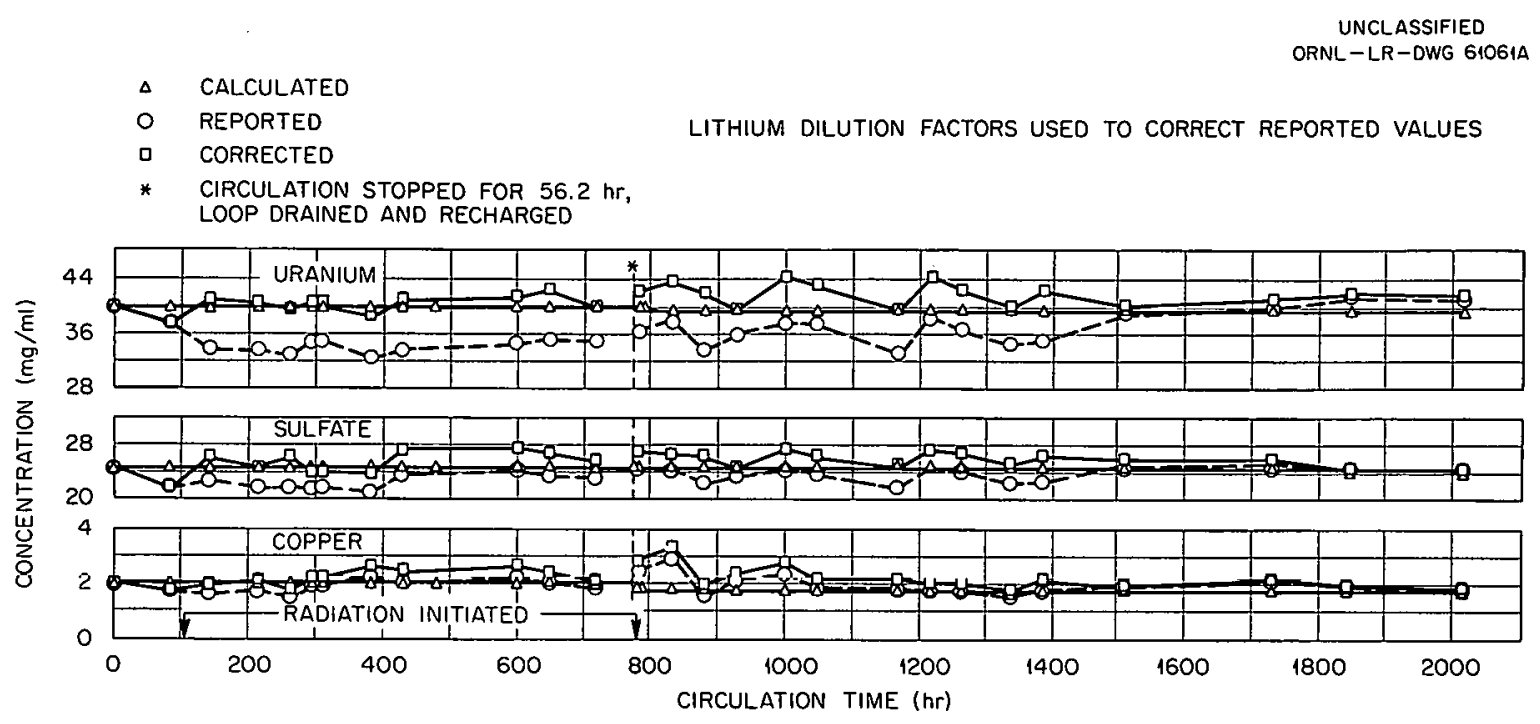

Fig. 12. Concentration of Uranium, Sulfate, and Copper in Solution Samples, Loop L-4-12.

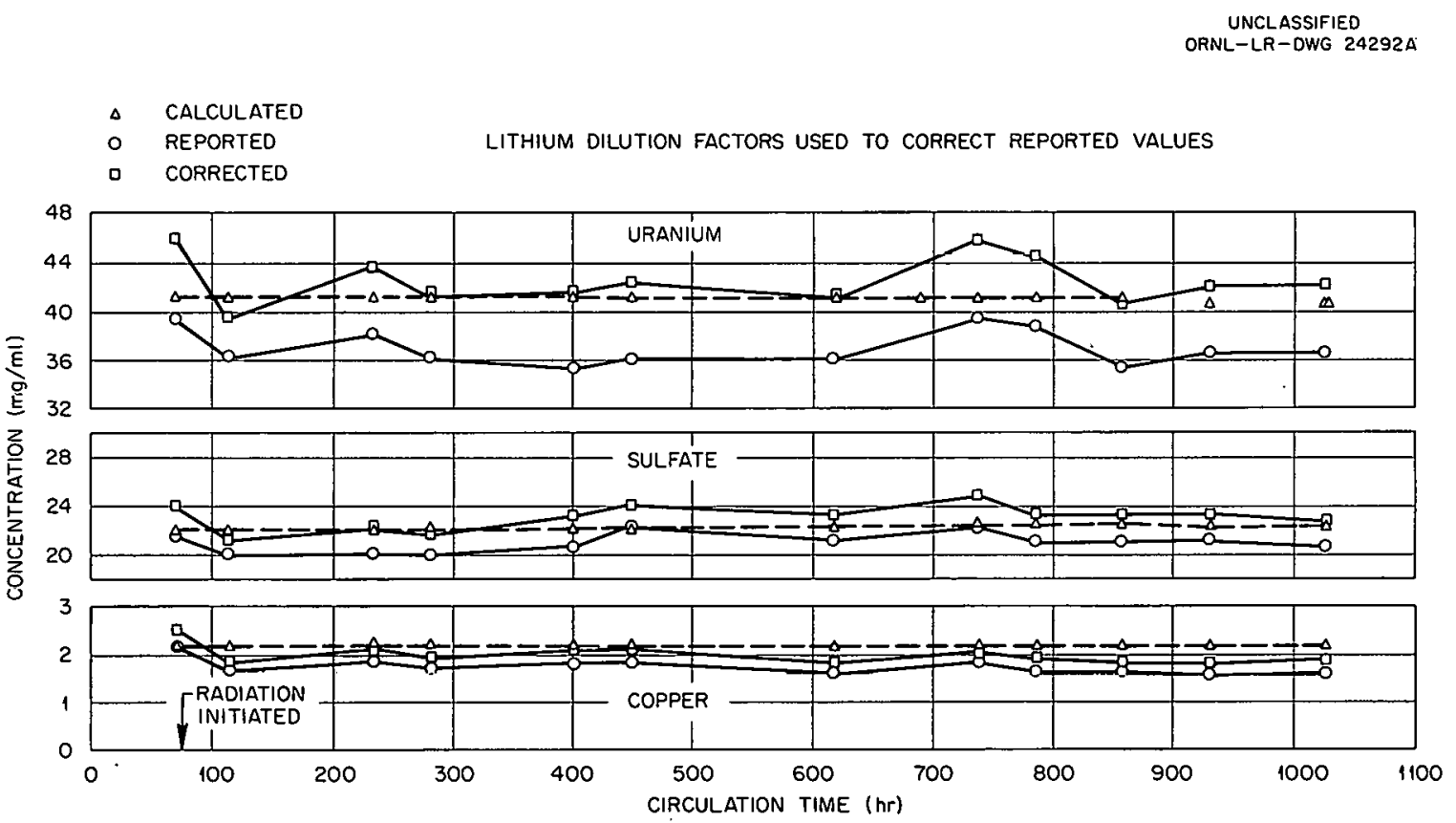

Fig. 13. Concentration of Uranium, Sulfate, and Copper in Solution Samples, Loop L-4-13. 


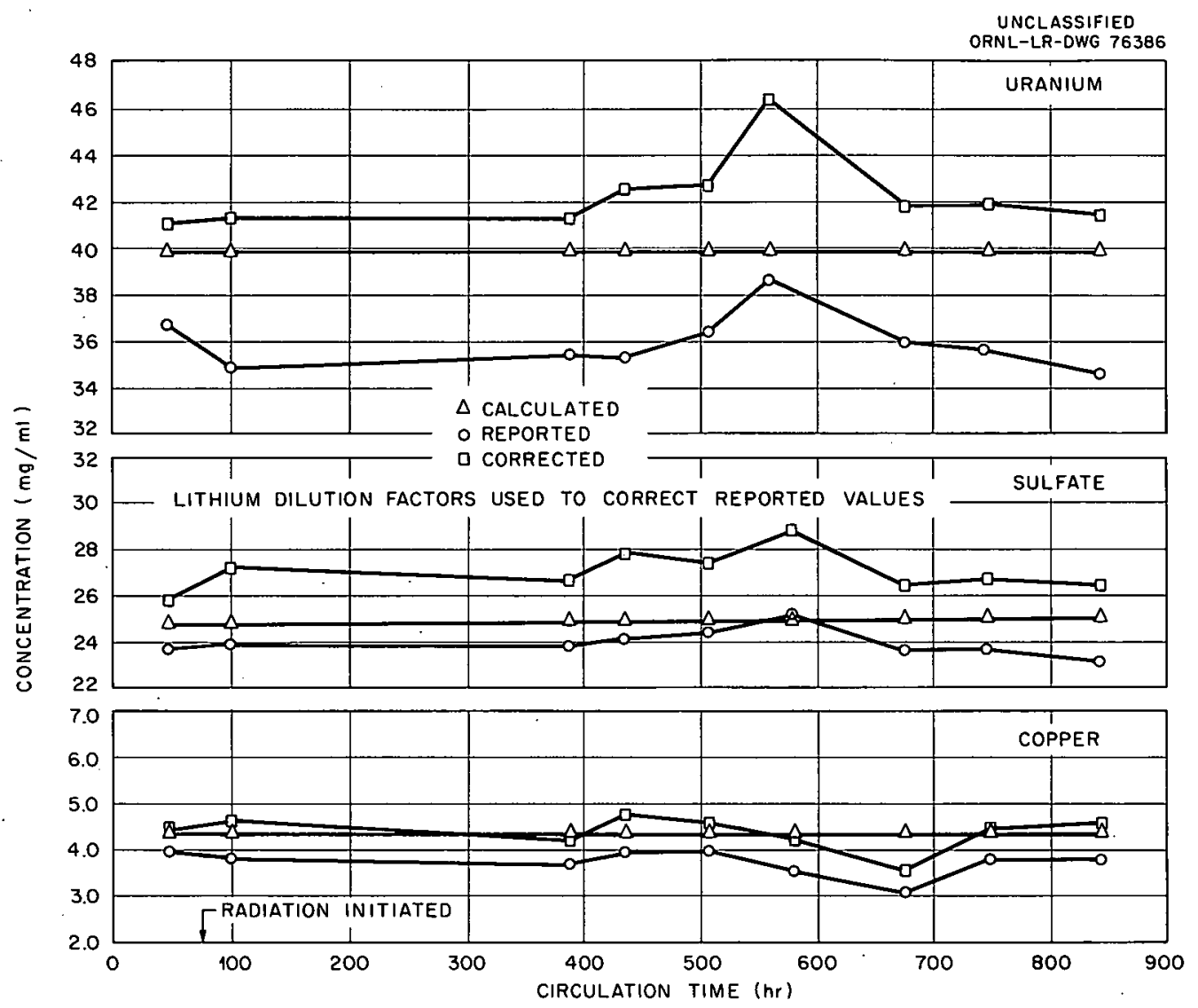

Fig. 14. Concentration of Uranium, Sulfate, and Copper in Solution Samples, Loop L-4-18.

Fig. 15. Overall Corrosion Penetration of Type 347 Stainless Steel, Loop DD.

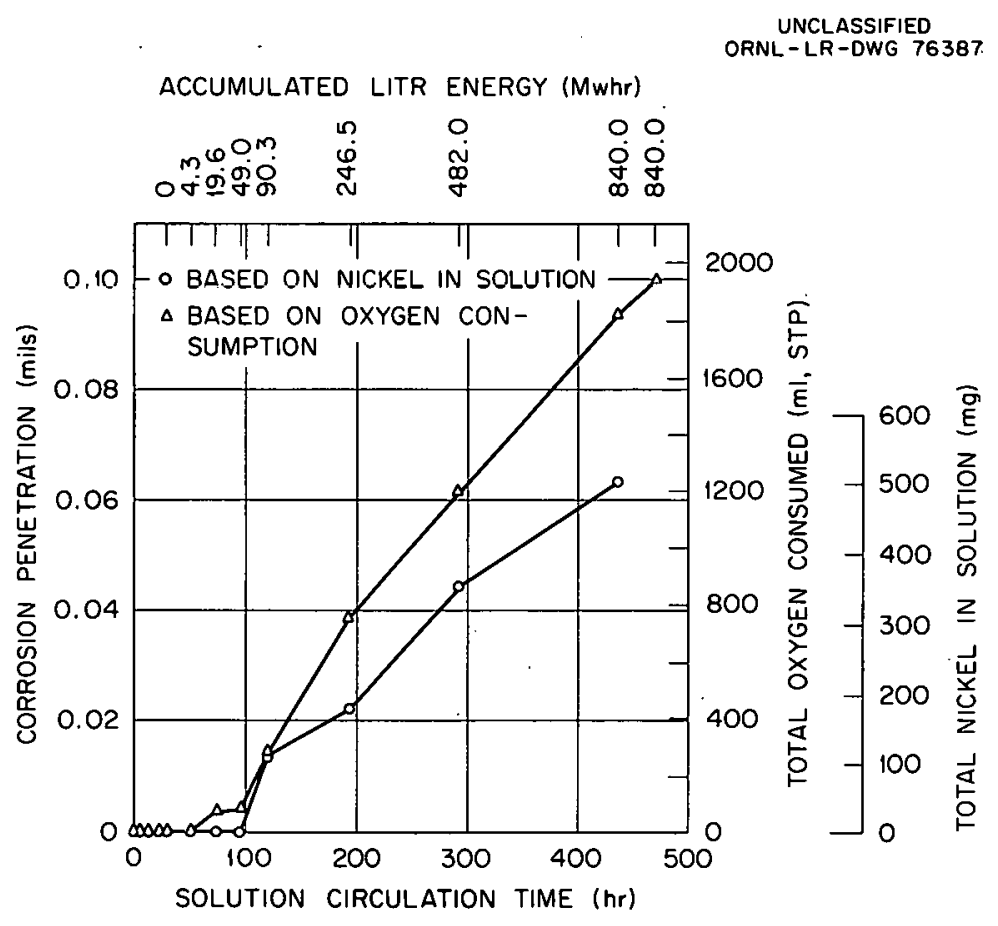




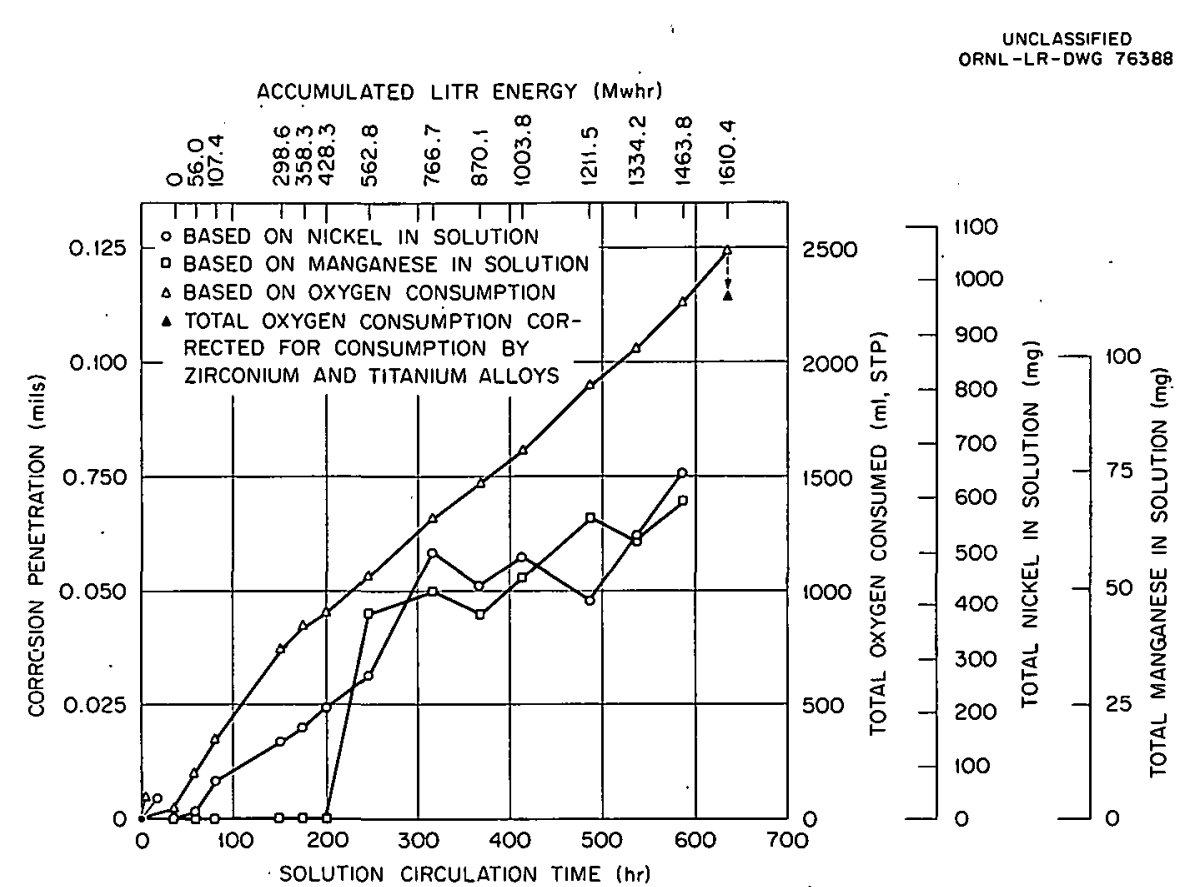

Fig. 16. Overall Corrosion Penetration of Type 347 Stainless Steel, Loop EE.

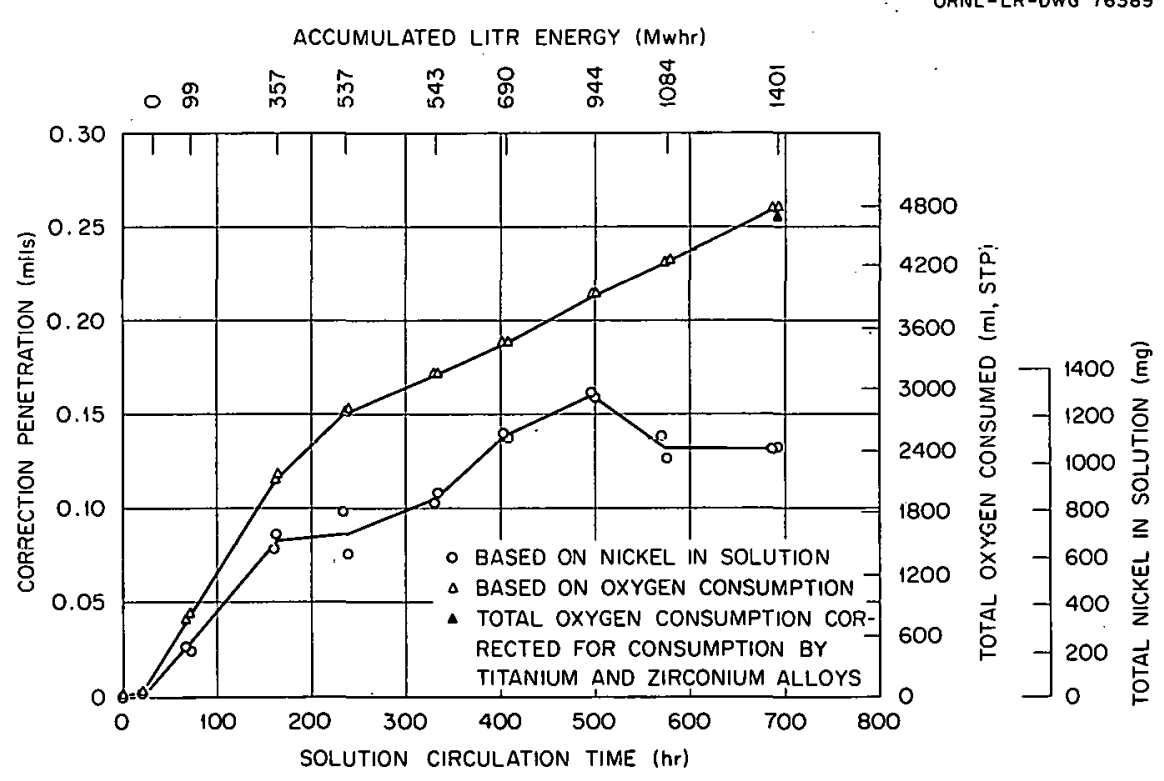

Fig. 17. Overall Corrosion Penetration of-Type 347 Stainless Steel, Loop FF. 
ACCUMULATED LITR ENERGY (Mwhr)

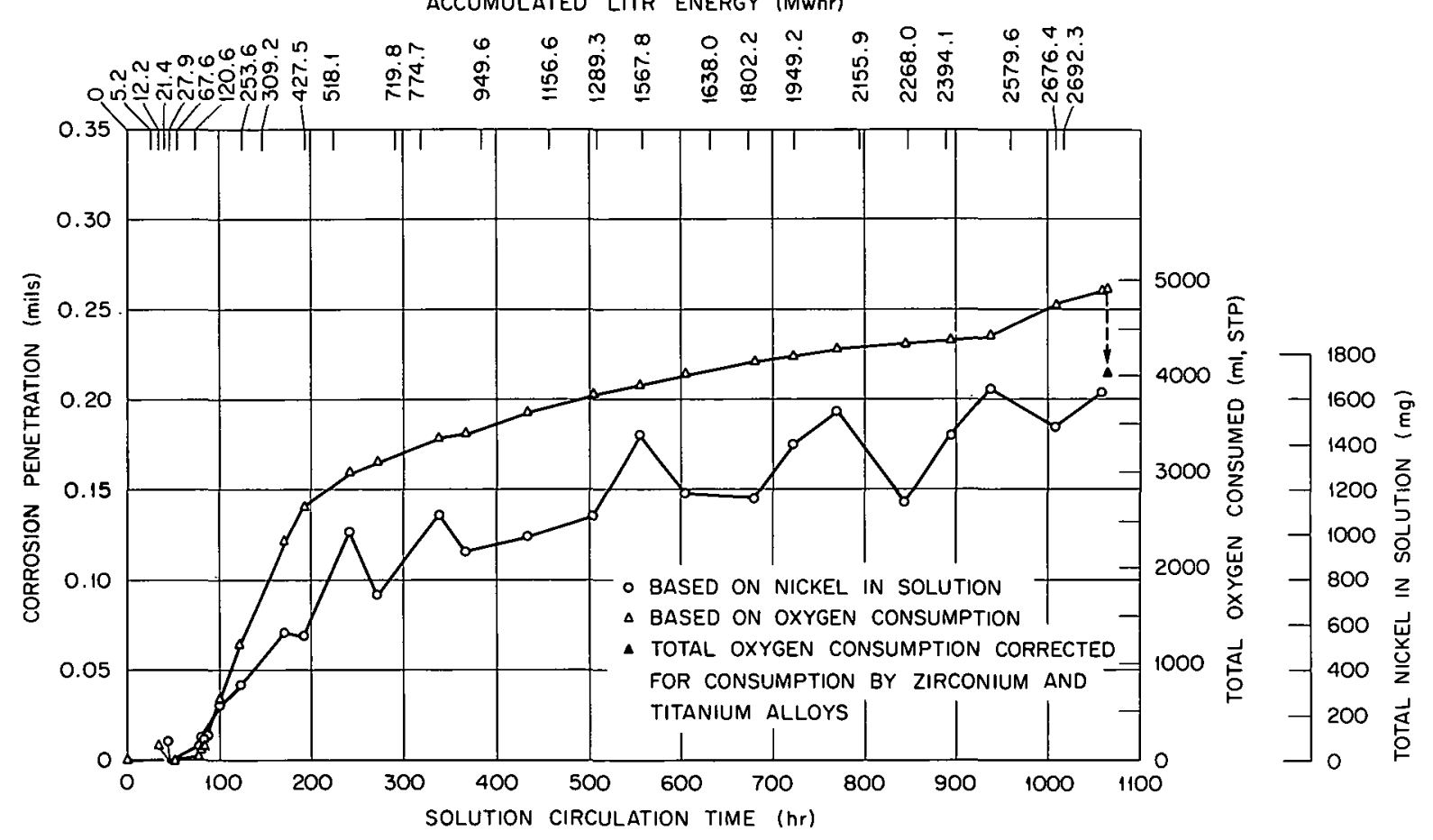

Fig. 18. Overall Corrosion Penetrotion of Type 347 Stainless Steel, Loop GG.

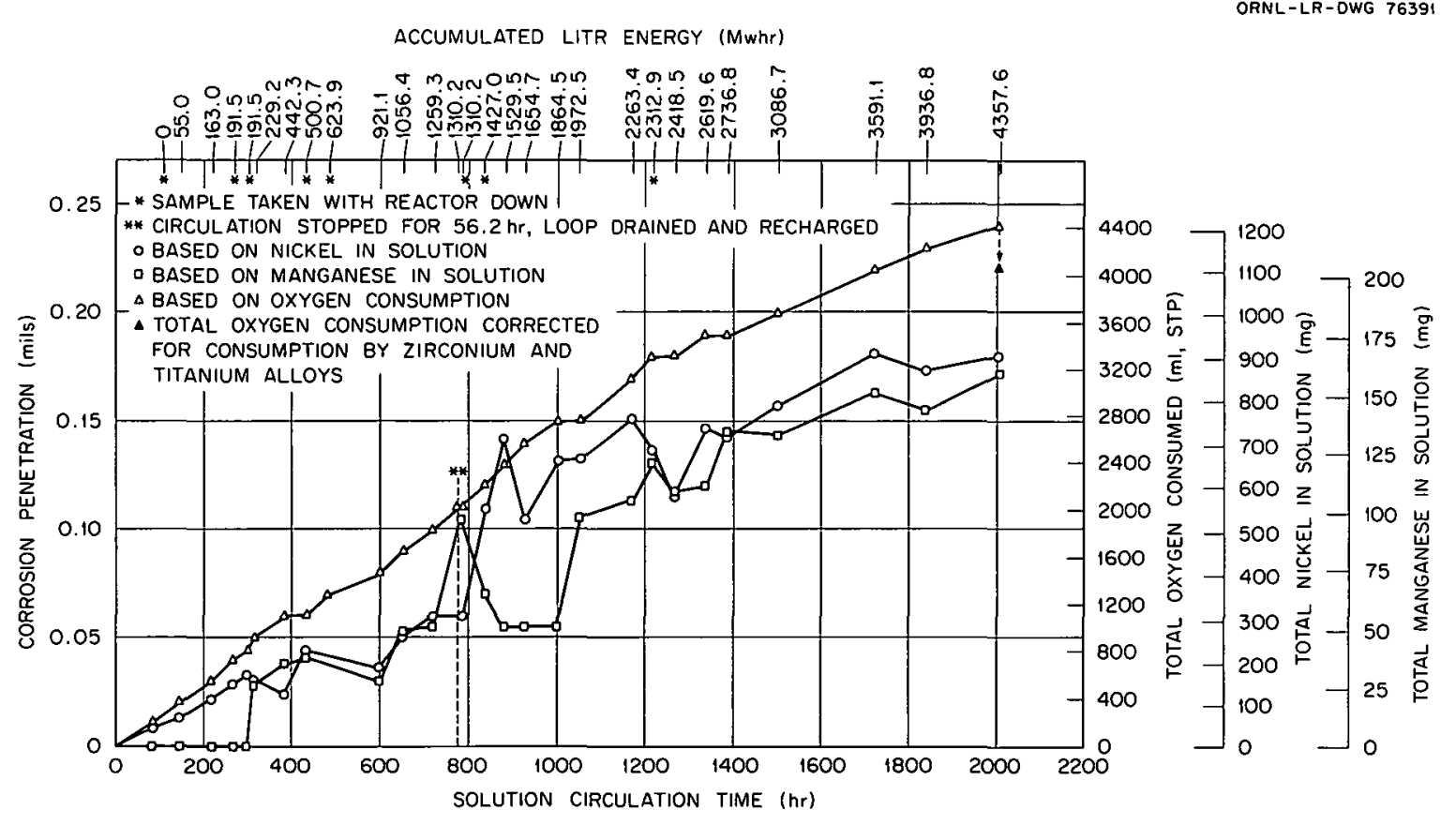

Fig. 19. Overall Corrosion Penetration of Type 347 Stainless Steel, Loop L-4-12. 
UNCLASSIFIED

ACCUMULATED LITR ENERGY (Mwhr)

ORNL-LR-DWG 76392

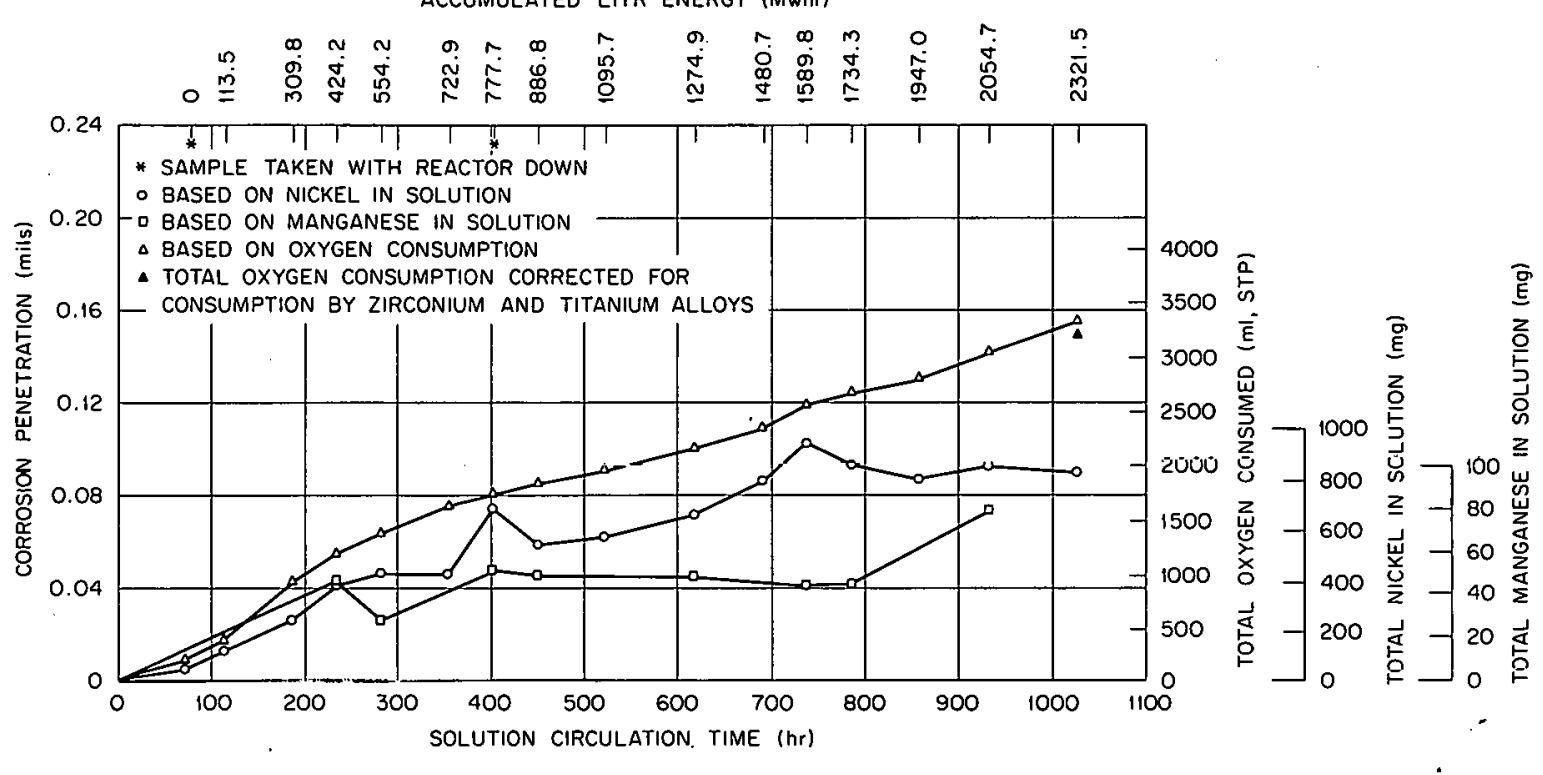

Fig. 20. Overall Corrosion Penetration of Type 347 Stainless Steel, Loop L-4-13.

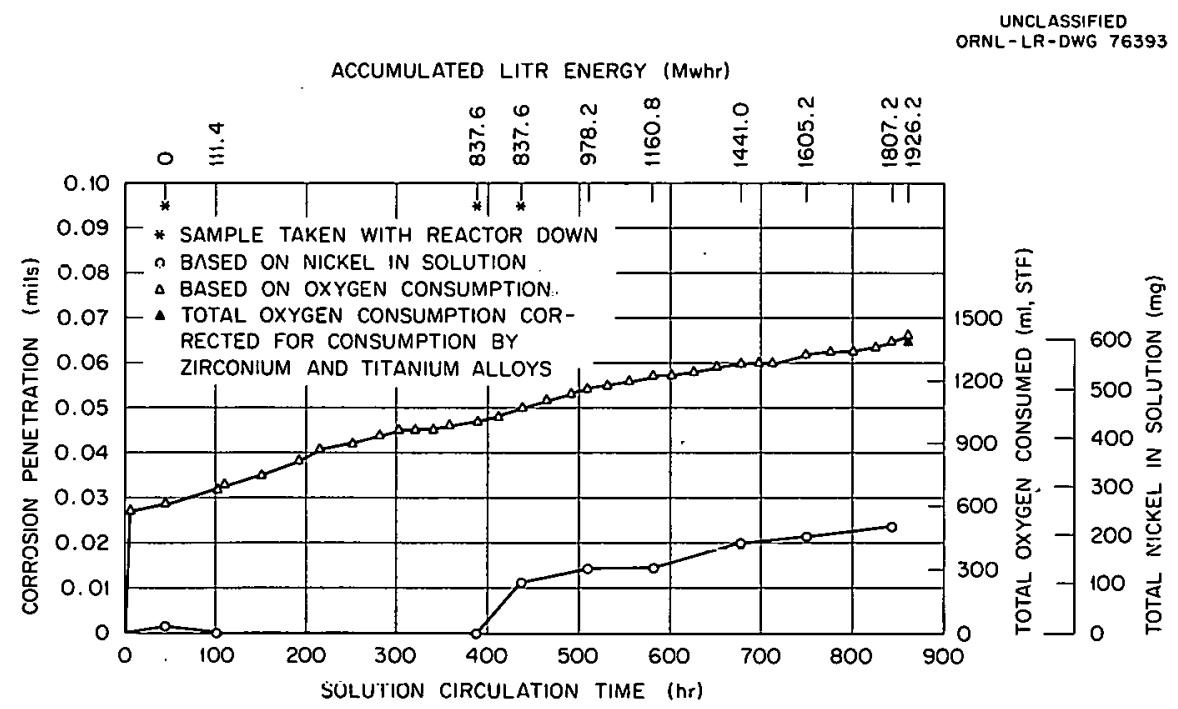

Fig. 21. Overall Corrosion Penetration of Type 347 Stainless Steel, Loop L-4-18. 


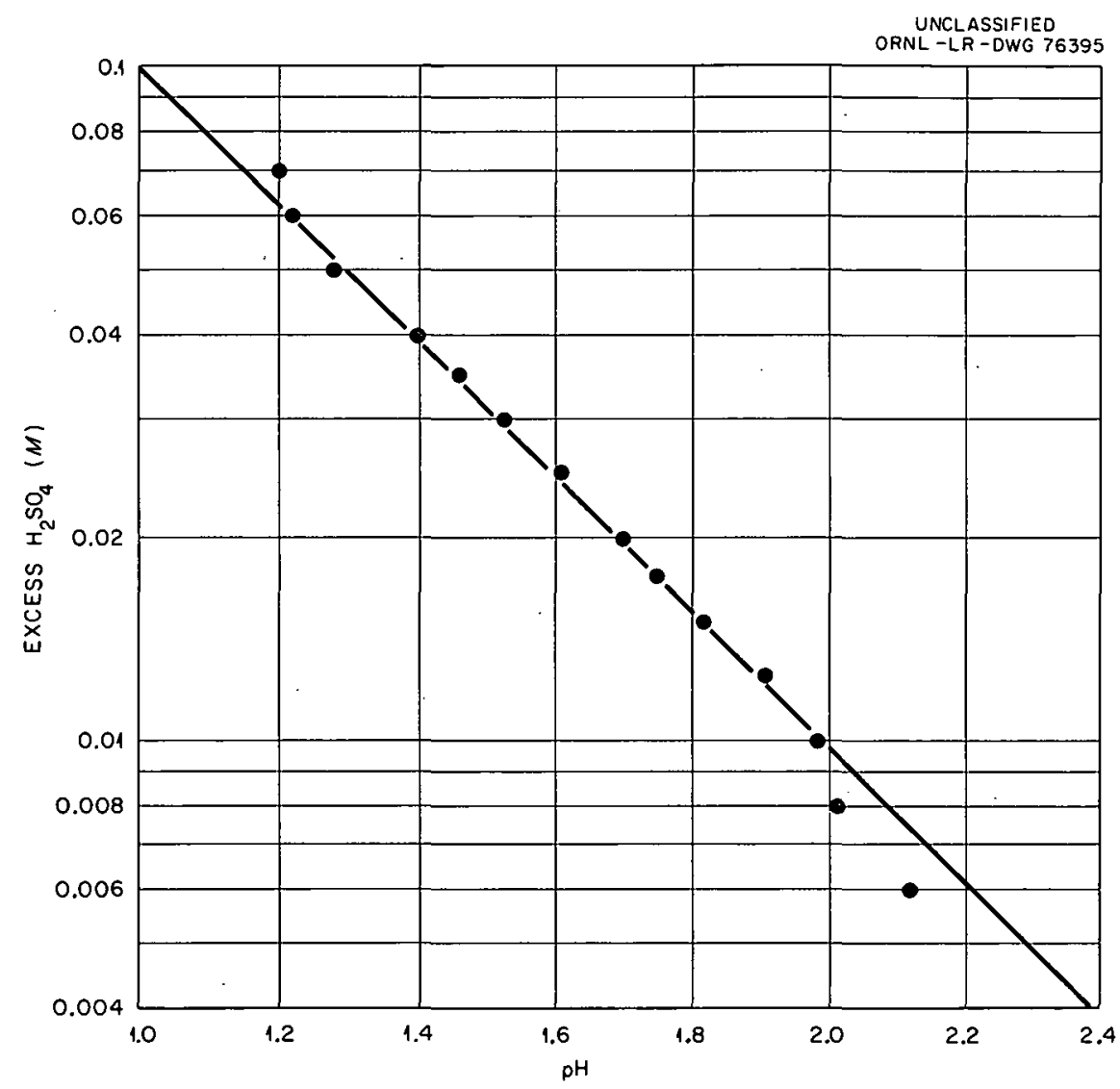

Fig. 22. Free-Acid Concentration vs $\mathrm{pH}$ in $\mathrm{H}_{2} \mathrm{O}$ Solutions Containing $0.17 \mathrm{~m} \mathrm{UO}_{2} \mathrm{SO}_{4}$ and $0.03 \mathrm{~m}$ $\mathrm{CuSO}_{4}$.

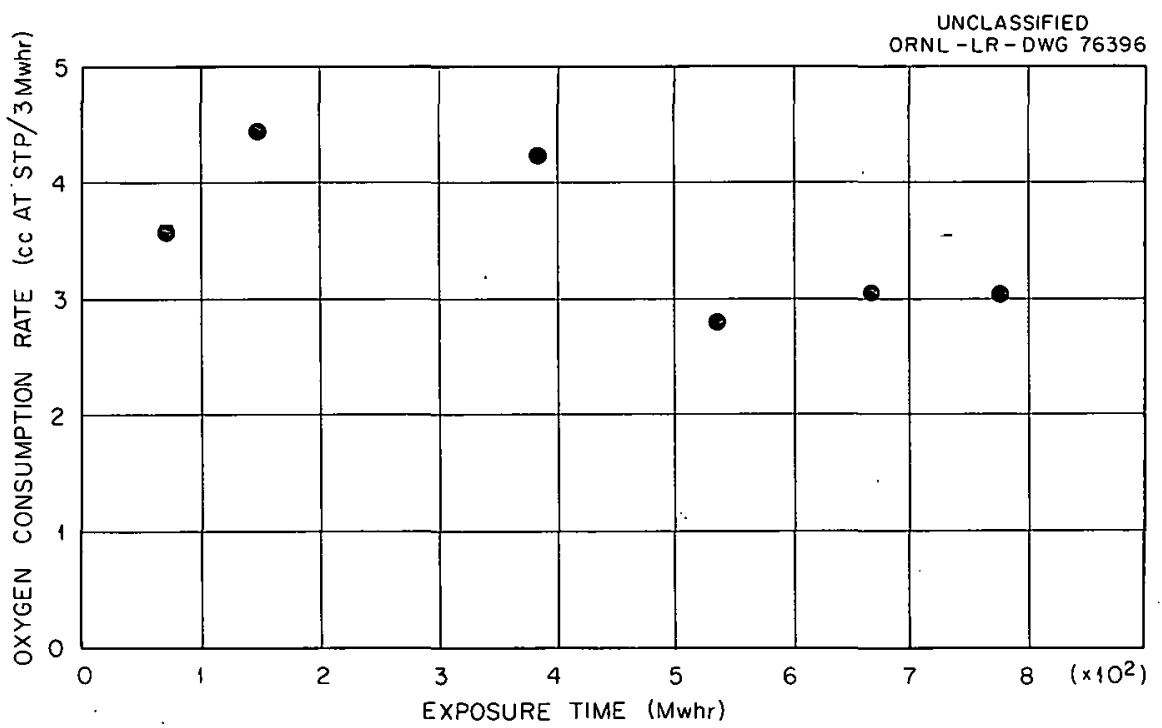

Fig. 23. Oxygen Consumption Rates on Stainless Steel, Loop DD. 


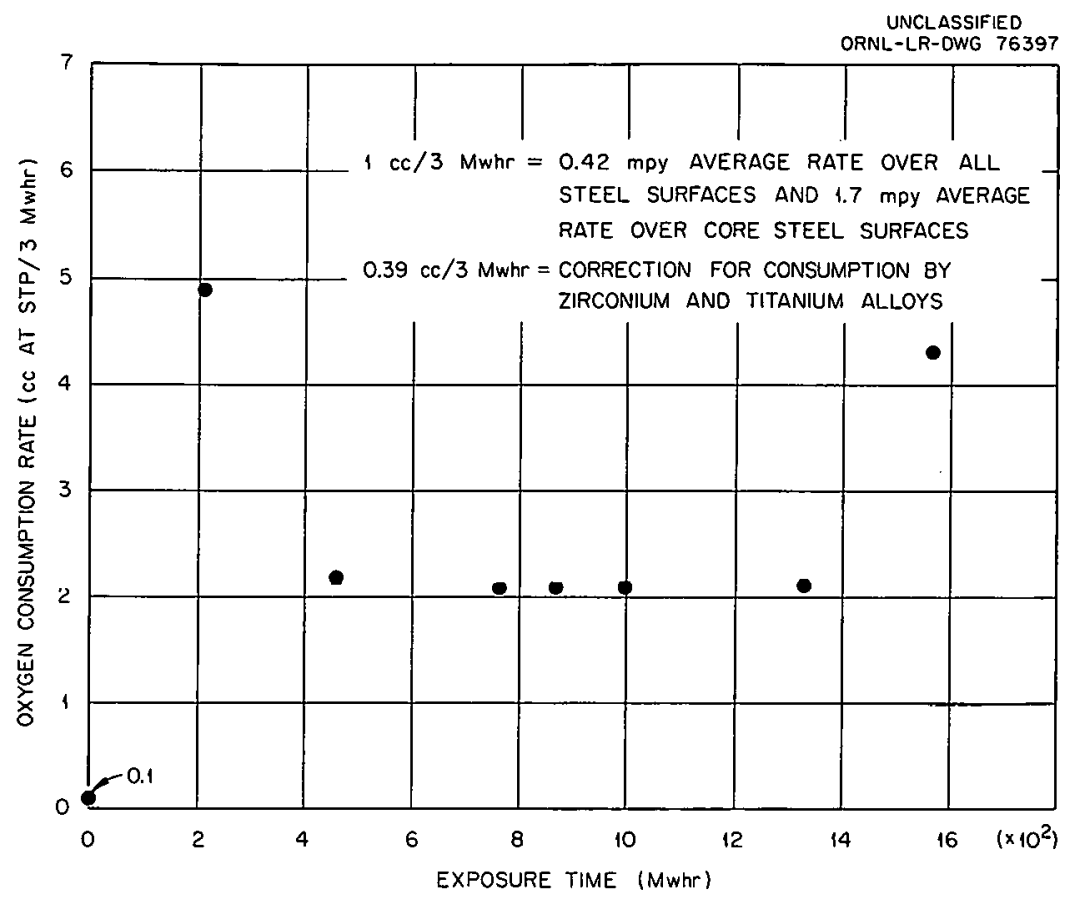

Fig. 24. Oxygen Consumption Rates on Stainless Steel, Loop EE.

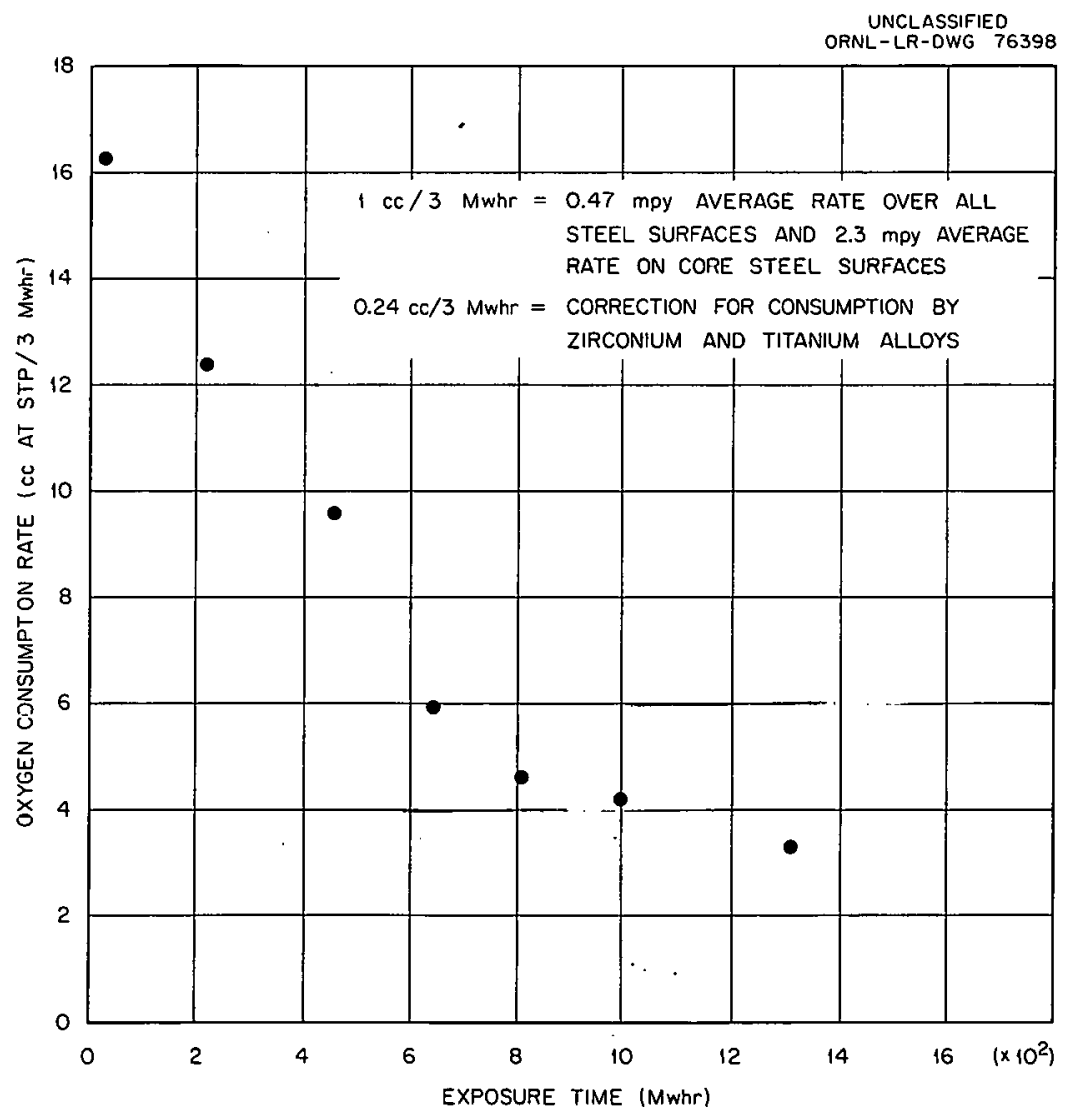

Fig. 25. Oxygen Consumption Rates on Stainless Steel, Loop FF. 


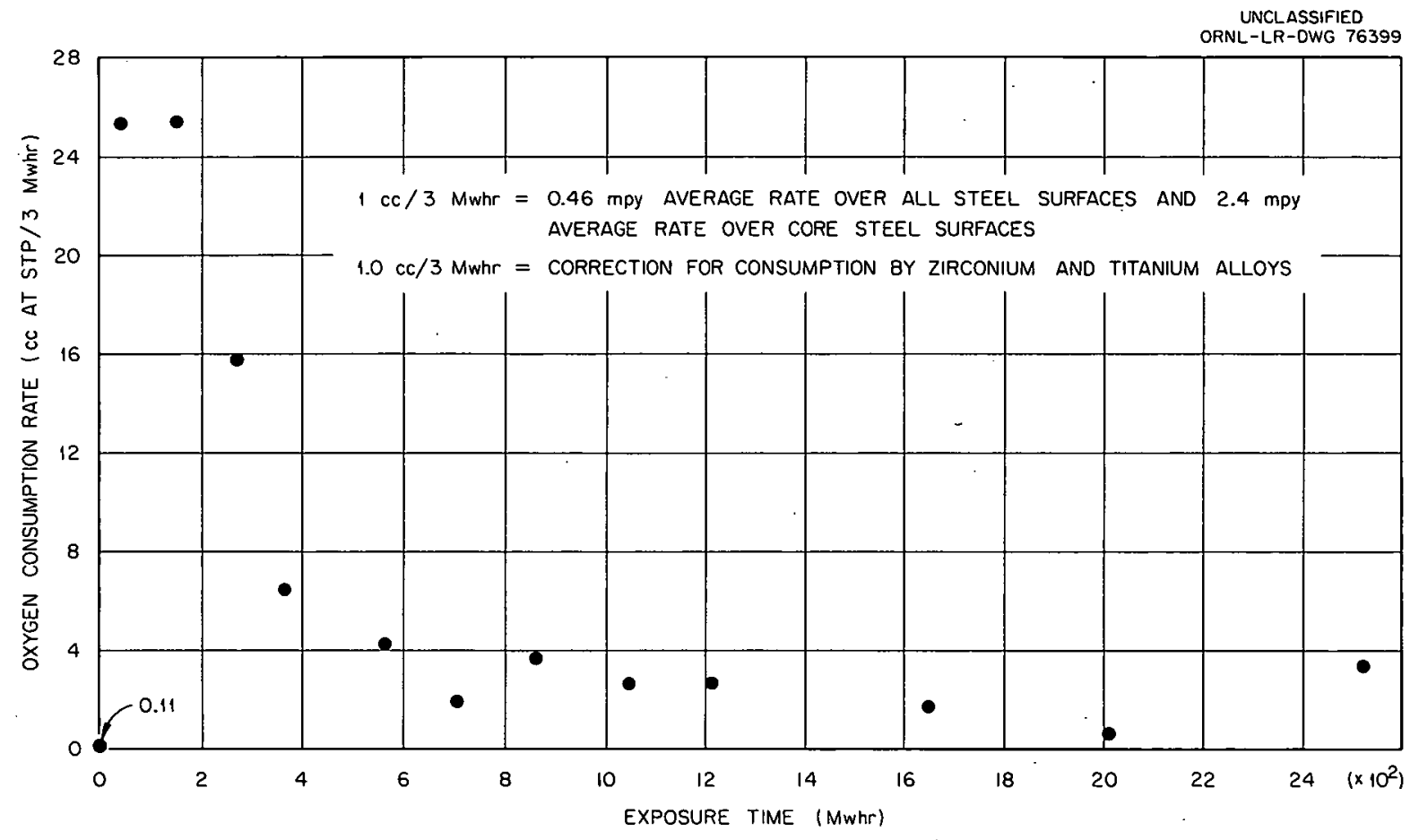

Fig. 26. Oxygen Consumption Rates on Stainless Steel, Loop GG.

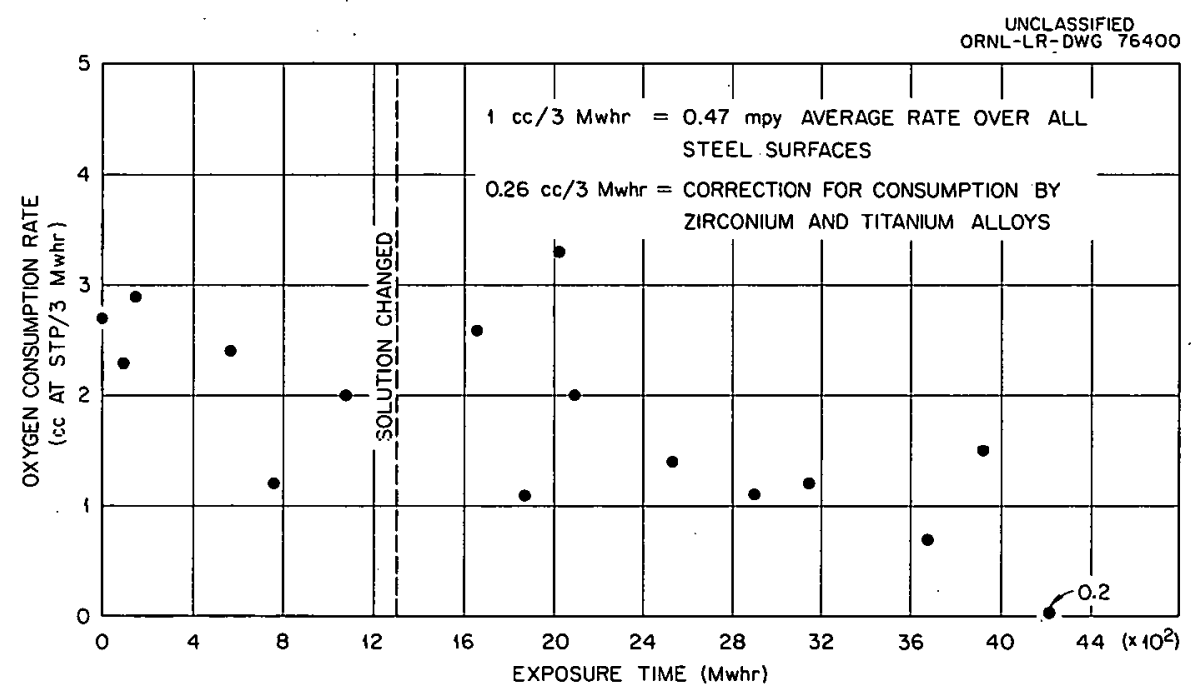

Fig. 27. Oxygen Consumption Rates on Stainless Steel, Loop L-4-12. 


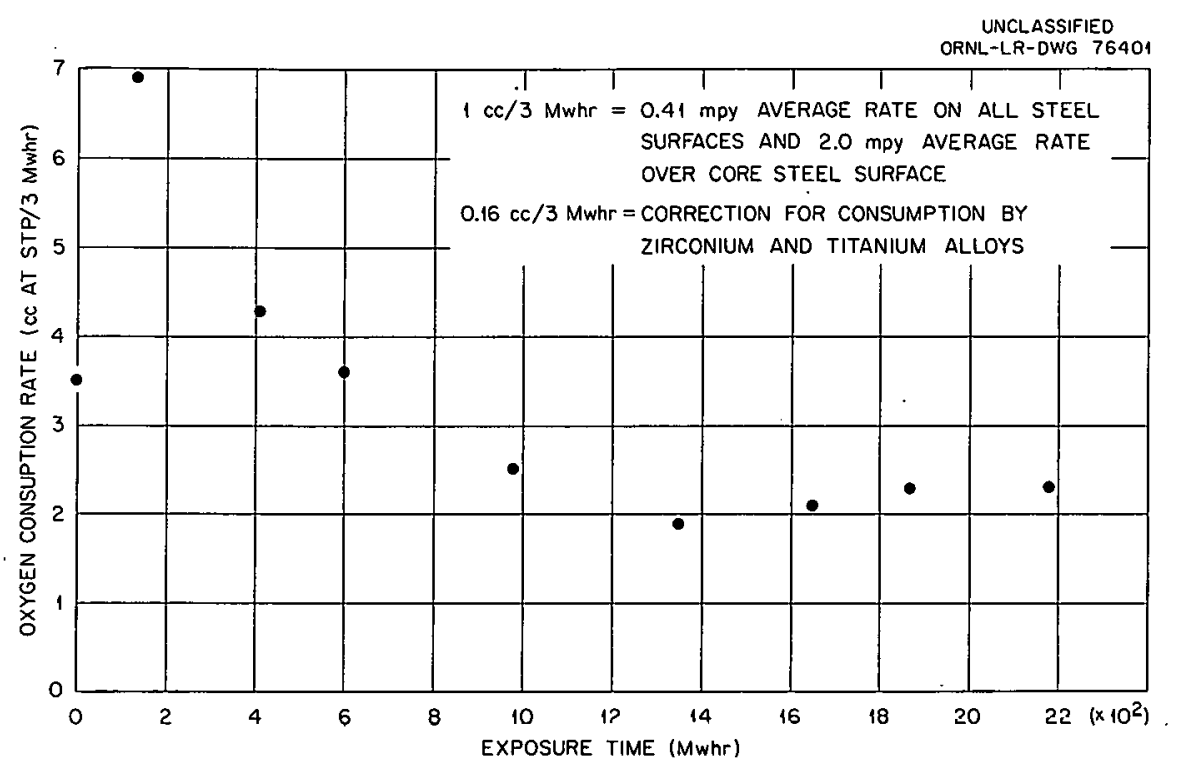

Fig. 28. Oxygen Consumption Rates on Stainless Steel, Loop L-4-13.

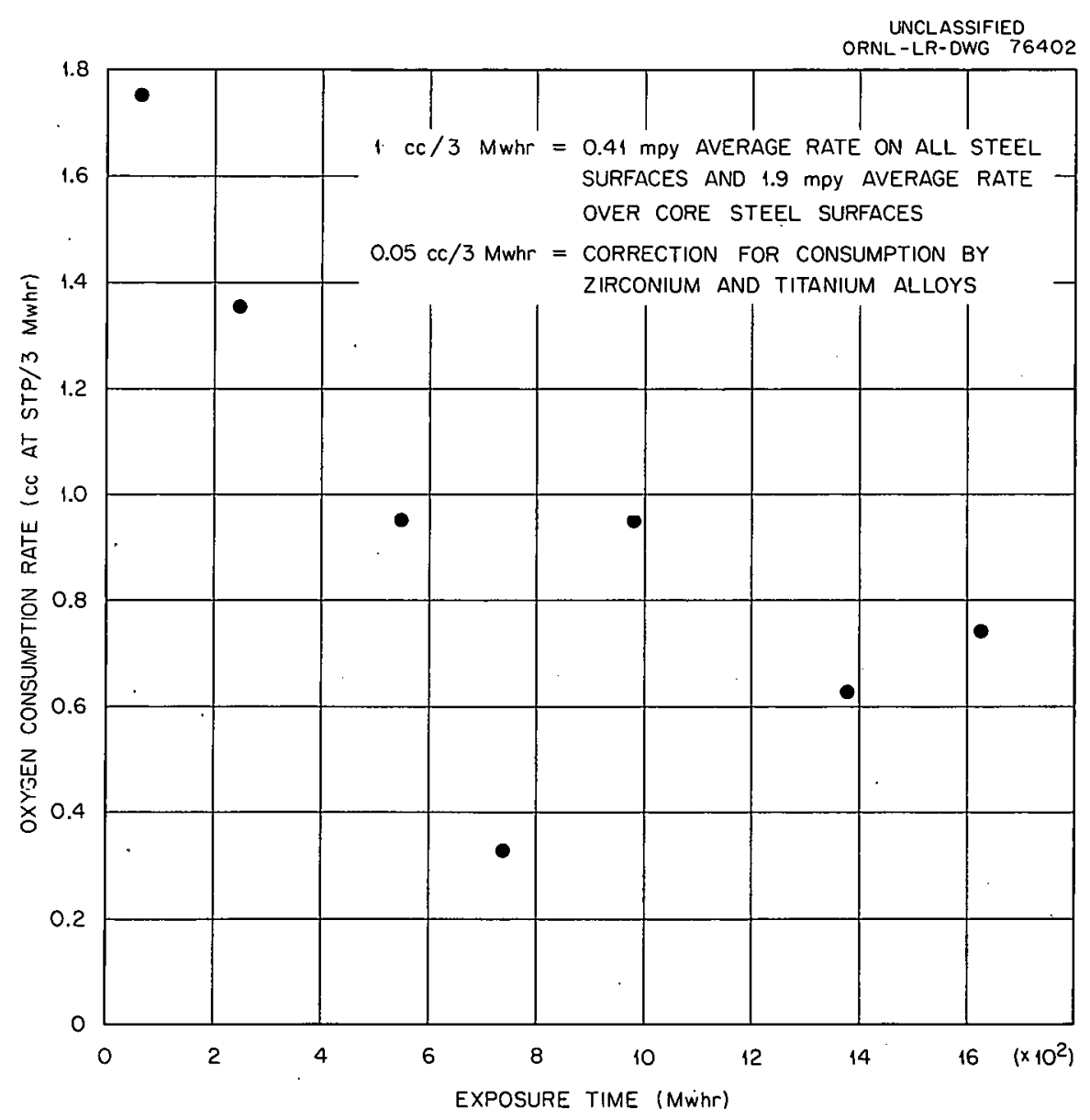

Fig. 29. Oxygen Consumption Rates on Stainless Steel, Loop L-4-18. 
Table 20. Oxygen Consumption in Loop DD

\begin{tabular}{|c|c|c|c|c|c|c|c|c|c|c|}
\hline Remarks & $\begin{array}{l}\text { LITR } \\
\text { Energy } \\
\text { (Mwhr) }\end{array}$ & $\begin{array}{l}\text { Sample } \\
\text { Number }\end{array}$ & $\begin{array}{c}\text { Total Fuel } \\
\text { Circulation } \\
\text { Time } \\
(\mathrm{hr})\end{array}$ & $\begin{array}{l}\Delta \\
\text { Time } \\
(h r)\end{array}$ & $\begin{array}{l}\mathrm{O}_{2} \text { Volume } \\
\text { at Time } \\
\text { of Previous } \\
\text { Sample } \\
\text { (cc at STP) }\end{array}$ & $\begin{array}{l}\mathrm{O}_{2} \text { Volume } \\
\text { at Time } \\
\text { of Sample } \\
\text { (cc at STP) }\end{array}$ & $\begin{array}{l}\mathrm{O}_{2} \text { Additions } \\
\text { (cc at STP) }\end{array}$ & $\begin{array}{c}\mathrm{O}_{2} \\
\text { Consumed } \\
\text { Since Last } \\
\text { Sample } \\
\text { (cc at STP) }\end{array}$ & $\begin{array}{l}\text { Cumulative }^{a} \\
\text { Amount of } \mathrm{O}_{2} \\
\text { Consumed } \\
\text { (cc at STP) }\end{array}$ & $\begin{array}{c}\text { Calculated } \\
\text { Corrosion } \\
\text { Penetration } \\
\text { of Type } 347 \\
\text { Stainless Steel } \\
\text { (mils) }\end{array}$ \\
\hline \multirow{5}{*}{$\begin{array}{l}\text { Enriched solution, } \\
\text { no radiation }\end{array}$} & 0 & DD-1-28(E) & 0 & 0 & 912 & 912 & & 0 & 0 & \\
\hline & 0 & $D D-1-29(E)$ & 2.4 & 2.4 & 912 & 912 & & 0 & 0 & \\
\hline & 0 & $D D-1-30(E)$ & 12.7 & 10.3 & 912 & 912 & & 0 & 0 & \\
\hline & 0 & $D D-1-31(E)$ & 23.3 & 10.6 & 912 & 912 & & 0 & 0 & \\
\hline & 0 & $\mathrm{DD}-1-31.5(\mathrm{E})$ & 29.4 & 6.1 & 912 & 912 & & 0 & 0 & \\
\hline \multicolumn{11}{|l|}{ Radiation, Mw } \\
\hline 0.3 & 4.3 & DD-1-32(ER) & 51.7 & 22.3 & 912 & 912 & & 0 & 0 & 0 \\
\hline 1.0 & 19.6 & DD-1-33(ER) & 72.3 & 20.6 & 212 & 906 & & 7 & 7 & $<0.01$ \\
\hline 2.0 & 49.0 & $\mathrm{DD}-1-34(\mathrm{ER})$ & 95.3 & 23.0 & 906 & 838 & & 67 & 74 & $<0.01$ \\
\hline 3.0 & 90.3 & DD-1-3؟(ER) & 120.0 & 24.7 & 838 & 642 & & 197 & 271 & 0.02 \\
\hline 3.0 & 246.5 & DD-1-36(ER) & 192.9 & 72.9 & 642 & 944 & 745 & 443 & 714 & 0.04 \\
\hline 3.0 & 482.0 & $\mathrm{DD}-1-3 i(\mathrm{ER})$ & 292.4 & 99.5 & 944 & 528 & & 416 & 1130 & 0.06 \\
\hline 3.0 & 840.0 & DD-1-38(ER) & 434.8 & 142.4 & 528 & 713 & 788 & 603 & 1733 & 0.09 \\
\hline 0 & 840.0 & DD-1-39(ER) & 465.5 & 30.7 & 713 & 607 & & 106 & 1839 & 0.10 \\
\hline
\end{tabular}

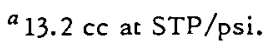


Table 21. Oxygen Consumption in Loop EE

\begin{tabular}{|c|c|c|c|c|c|c|c|c|c|c|}
\hline Remarks & $\begin{array}{l}\text { Sample } \\
\text { Number }\end{array}$ & $\begin{array}{c}\text { Accumulated } \\
\text { LITR } \\
\text { Energy } \\
\text { (Niwhr) }\end{array}$ & $\begin{array}{l}\text { Total } \\
\text { Solution } \\
\text { Circulation } \\
\text { Time } \\
\text { (hr) }\end{array}$ & $\begin{array}{c}\mathrm{O}_{2} \\
\text { Additions } \\
\text { to Loop } \\
\text { (cc at STP) }\end{array}$ & $\begin{array}{c}\mathrm{O}_{2} \\
\text { Withdrawn } \\
\text { from Loop }{ }^{a} \\
\text { (cc at STP) }\end{array}$ & $\begin{array}{c}\text { Total } \mathrm{O}_{2} \\
\text { Charged to Loop } \\
\text { Less } \mathrm{O}_{2} \\
\text { Withdrawn in } \\
\text { Sampling } \\
\text { (cc at STP) }\end{array}$ & $\begin{array}{l}\mathrm{O}_{2} \text { Volume } \\
\text { at Time of } \\
\text { Sampling } \\
\text { (cc at STP) }\end{array}$ & $\begin{array}{c}\mathrm{O}_{2} \\
\text { Consumed } \\
\text { Since Last } \\
\text { Sampling } \\
\text { (cc at STP) }\end{array}$ & $\begin{array}{c}\text { Cumulative } \\
\text { Amount } \\
\text { of } \mathrm{O}_{2} \\
\text { Consumed } \\
\text { (cc at STP) }\end{array}$ & $\begin{array}{c}\text { Calculated } \\
\text { Corrosion } \\
\text { Penetration } \\
\text { of Type } 347 \\
\text { Stainless Steel } \\
\text { (mils) }\end{array}$ \\
\hline Original filling & & 0.0 & 0.0 & 795 & 0 & 795 & 795 & 0 & 0 & 0 \\
\hline \multirow[t]{2}{*}{$\begin{array}{l}\mathrm{O}_{2} \text { addition } \\
(\mathrm{EE}-2)\end{array}$} & & 0.0 & 21.5 & 839 & 0 & 1634 & 1601 & & 33 & \\
\hline & $E E-1-92$ & 0.0 & 33.3 & 0 & 0 & 1634 & 1583 & 51 & 51 & 0.003 \\
\hline \multirow[t]{7}{*}{ Reactor started } & & 0.0 & 36.2 & 0 & 6 & 1628 & 1572 & & 56 & \\
\hline & $E E=1.93$ & 56.0 & 54.8 & 0 & 0 & 1622 & 1432 & 139 & 190 & 0.01 \\
\hline & $E E-1-94$ & 107.4 & 76.3 & 0 & 7 & 1616 & $12 ? 2$ & 154 & 344 & 0.02 \\
\hline & EE-1.95 & 298.6 & 148.1 & 0 & 6 & 1610 & 868 & 418 & 762 & 0.04 \\
\hline & EE-1-96 & 358.3 & 172.6 & 0 & 4 & 1606 & 786 & 58 & 820 & 0.04 \\
\hline & EE-1.97 & 428.3 & 196.7 & 0 & 6 & 1600 & 698 & 82 & 902 & 0.05 \\
\hline & EE-1-98 & 562.8 & 244.6 & 0 & 10 & 1590 & 529 & 159 & 1061 & 0.05 \\
\hline \multirow{6}{*}{$\begin{array}{c}\mathrm{O}_{2} \text { addition } \\
(\mathrm{EE}-3)\end{array}$} & & & 251.3 & 986 & 8 & 2567 & 1490 & & 1077 & \\
\hline & $E E \cdot 1.99$ & 766.7 & 316.6 & 0 & 0 & 2567 & 1253 & 253 & 1314 & 0.07 \\
\hline & $\mathrm{EE}-1-100$ & 870.1 & 364.3 & 0 & 15 & 2553 & 1093 & 146 & 1460 & 0.07 \\
\hline & $E E-1-101$ & 1003.8 & 412.4 & 0 & 5 & 2548 & 933 & 155 & 1615 & 0.08 \\
\hline & $E E-1.102$ & 1211.5 & 484.4 & 0 & 4 & 2544 & 6.7 & 272 & 1887 & 0.09 \\
\hline & EE-1-104 & 1334.2 & 532.2 & 0 & 3 & 2542 & 484 & 171 & 2058 & 0.10 \\
\hline \multirow{2}{*}{$\begin{array}{c}\mathrm{O}_{2} \text { addition } \\
(\mathrm{EE}-4)\end{array}$} & & & 557.5 & 917 & 2 & 3457 & 1310 & & 2147 & \\
\hline & EE-1.104 & 1463.8 & 580.5 & 0 & 0 & 3457 & 1205 & 194 & 2252 & 0.11 \\
\hline End of run & & 1610.4 & 630.3 & 0 & 5 & 3451 & 977 & 222 & 2474 & 0.12 \\
\hline
\end{tabular}

${ }^{a}$ Calculated amount removed as $\mathrm{O}_{2}$ dissolved in sample.

$b_{12.0} \mathrm{cc}$ at STP/psi. 
Table 22. Oxygen Consumption in Loop FF

\begin{tabular}{|c|c|c|c|c|c|c|c|c|c|c|}
\hline Remarks & $\begin{array}{l}\text { Sample } \\
\text { Number }\end{array}$ & $\begin{array}{c}\text { LITR } \\
\text { Energy } \\
\text { (Mwhr) }\end{array}$ & $\begin{array}{l}\text { Total } \\
\text { Solution } \\
\text { Circulation } \\
\text { Time } \\
\text { (hr) }\end{array}$ & $\begin{array}{c}\mathrm{O}_{2} \\
\text { Additions } \\
\text { to Loop } \\
\text { (cc at STP) }\end{array}$ & $\begin{array}{c}\mathrm{O}_{2} \\
\text { Withdrawn } \\
\text { from Loop } \\
\text { (cc at STP) }\end{array}$ & $\begin{array}{c}\text { Total } \mathrm{O}_{2} \\
\text { Charged to Loop } \\
\text { Less } \mathrm{O}_{2} \text { Withdrawn } \\
\text { in Sampling } \\
\text { (cc at STP) }\end{array}$ & $\begin{array}{c}\mathrm{O}_{2} \text { Volume } \\
\text { at Time of } \\
\text { Sample } \\
\text { (cc at STP) }\end{array}$ & $\begin{array}{c}\mathrm{O}_{2} \\
\text { Consumed } \\
\text { Since Last } \\
\text { Sample } \\
\text { (cc at STP) }\end{array}$ & $\begin{array}{c}\text { Cumulative }^{b} \\
\text { Amount } \\
\text { of } \mathrm{O}_{2} \\
\text { Consumed } \\
\text { (cc of STP) }\end{array}$ & $\begin{array}{c}\text { Calculated } \\
\text { Corrosion } \\
\text { Penetration } \\
\text { of Type } 347 \\
\text { Stainless Steel } \\
\text { (mils) }\end{array}$ \\
\hline \multicolumn{11}{|l|}{ Mockup operation } \\
\hline Original $\mathrm{O}_{2}$ fill & $\begin{array}{l}F F-1-40 \\
F F-1-41\end{array}$ & $\begin{array}{l}0 \\
0 \\
0\end{array}$ & $\begin{array}{c}0 \\
1.5 \\
20.8\end{array}$ & 1124 & $\begin{array}{r}0 \\
24 \\
7\end{array}$ & $\begin{array}{l}1124 \\
1100 \\
1093\end{array}$ & & 0 & 0 & 0.002 \\
\hline Circulating pump shut down & & 0 & 23.1 & & 0 & 1093 & 1052 & & 41 & \\
\hline $\begin{array}{l}\text { LITR operation } \\
\text { Reactor started up }\end{array}$ & $\begin{array}{r}F F-1-44 \text { (a) } \\
\text { (b) }\end{array}$ & $\begin{array}{c}0 \\
99.0 \\
99.0\end{array}$ & $\begin{array}{l}30.9 \\
67.8 \\
71.1\end{array}$ & $\begin{array}{l}0 \\
0 \\
0\end{array}$ & $\begin{array}{r}0 \\
13\end{array}$ & $\begin{array}{l}1093 \\
1093 \\
1093\end{array}$ & $\begin{array}{r}1052 \\
342 \\
291\end{array}$ & $\begin{array}{r}713 \\
51\end{array}$ & $\begin{array}{r}41 \\
751 \\
802\end{array}$ & $\begin{array}{l}0.002 \\
0.04 \\
0.04\end{array}$ \\
\hline $\mathrm{O}_{2}$ addition $\mathrm{FF}-\mathrm{I}$ & $\begin{array}{r}F F=1-45 \text { (a) } \\
\text { (b) }\end{array}$ & $\begin{array}{l}357.2 \\
357.2\end{array}$ & $\begin{array}{r}71.8 \\
161.2 \\
163.4\end{array}$ & $\begin{array}{r}1361 \\
0 \\
0\end{array}$ & $\begin{array}{l}0 \\
3\end{array}$ & $\begin{array}{l}2441 \\
2441 \\
2441\end{array}$ & $\begin{array}{r}1641 \\
290 \\
252\end{array}$ & $\begin{array}{r}1349 \\
38\end{array}$ & $\begin{array}{l}2151 \\
2189\end{array}$ & $\begin{array}{l}0.12 \\
0.12\end{array}$ \\
\hline $\mathrm{O}_{2}$ addition $\mathrm{FF}-2$ & $\begin{array}{r}F F-1.46 \text { (a) } \\
\text { (b) }\end{array}$ & $\begin{array}{l}536.5 \\
536.5\end{array}$ & $\begin{array}{l}165.0 \\
234.4 \\
236.4\end{array}$ & $\begin{array}{r}1092 \\
0 \\
0\end{array}$ & $\begin{array}{r}0 \\
10\end{array}$ & $\begin{array}{l}3530 \\
3530 \\
3530\end{array}$ & $\begin{array}{r}1344 \\
714 \\
697\end{array}$ & $\begin{array}{r}627 \\
.17\end{array}$ & $\begin{array}{l}2816 \\
2833\end{array}$ & $\begin{array}{l}0.15 \\
0.15\end{array}$ \\
\hline $\mathrm{O}_{2}$ addition $\mathrm{FF}-3$ & $\begin{array}{r}F F-1.47 \text { (a) } \\
\text { (b) } \\
\text { FF-1.48 (a) } \\
\text { (b) }\end{array}$ & $\begin{array}{l}543.3 \\
543.3 \\
689.8 \\
689.8\end{array}$ & $\begin{array}{l}238.7 \\
330.1 \\
332.0 \\
401.6 \\
403.6\end{array}$ & $\begin{array}{r}610 \\
0 \\
0 \\
0 \\
0\end{array}$ & $\begin{array}{r}0 \\
10\end{array}$ & $\begin{array}{l}4130 \\
4130 \\
4130 \\
4120 \\
4120\end{array}$ & $\begin{array}{r}1324 \\
928 \\
928 \\
617 \\
606\end{array}$ & $\begin{array}{r}369 \\
0 \\
301 \\
11\end{array}$ & $\begin{array}{l}3202 \\
3202 \\
3503 \\
3514\end{array}$ & $\begin{array}{l}0.17 \\
0.17 \\
0.19 \\
0.19\end{array}$ \\
\hline $\mathrm{O}_{2}$ addition $\mathrm{FF}-4$ & & & 473.9 & 799 & 0 & 4912 & & & & \\
\hline & $\begin{array}{r}F F-1.49 \text { (a) } \\
\text { (b) } \\
F F-1-50 \text { (a) } \\
\text { (b) }\end{array}$ & $\begin{array}{r}943.8 \\
943.8 \\
1084.4 \\
1084.4\end{array}$ & $\begin{array}{l}497.3 \\
498.8 \\
572.1 \\
575.5\end{array}$ & $\begin{array}{l}0 \\
0 \\
0 \\
0\end{array}$ & 10 & $\begin{array}{l}4912 \\
4912 \\
4902 \\
4902\end{array}$ & $\begin{array}{l}908 \\
902 \\
582 \\
568\end{array}$ & $\begin{array}{r}490 \\
6 \\
310 \\
14\end{array}$ & $\begin{array}{l}4004 \\
4010 \\
4320 \\
4334\end{array}$ & $\begin{array}{l}0.21 \\
0.22 \\
0.23 \\
0.23\end{array}$ \\
\hline $\mathrm{O}_{2}$ addition $\mathrm{FF}-5$ & & & 576.0 & 682 & 0 & 5577 & 1245 & & & \\
\hline Sample taken with reactor on & $F F-1-52$ & 1401.2 & 687.9 & 0 & 9 & 5577 & 697 & 546 & 4880 & 0.26 \\
\hline Reactor shut down & $F F=1.53$ & $\begin{array}{l}1401.2 \\
1401.2\end{array}$ & $\begin{array}{l}687.9 \\
692.3\end{array}$ & 0 & & $\begin{array}{l}5577 \\
5577\end{array}$ & 687 & 10 & 4890 & 0.26 \\
\hline Circulating pump shue down & & 1401.2 & 693.0 & 0 & & 5577 & 683 & 4 & 4894 & 0.26 \\
\hline
\end{tabular}

${ }^{a}$ Calculated amount removed as $\mathrm{O}_{2}$ dissolved in sample.
${ }^{b} 10.5 \mathrm{cc}$ at STP/psi. 
Table 23. Oxygen Consumption in Loop GG

\begin{tabular}{|c|c|c|c|c|c|c|c|c|c|c|}
\hline Remarks & $\begin{array}{l}\text { Sample } \\
\text { Number }\end{array}$ & $\begin{array}{c}\text { LITR } \\
\text { Energy } \\
\text { (Mwhr) }\end{array}$ & $\begin{array}{l}\text { Total } \\
\text { Solution } \\
\text { Circulation } \\
\text { Time } \\
\text { (hr) }\end{array}$ & $\begin{array}{c}\mathrm{O}_{2} \\
\text { Additions } \\
\text { to Loop } \\
\text { (cc at STP) }\end{array}$ & $\begin{array}{c}\mathrm{O}_{2} \\
\text { Withdrawn } \\
\text { from Loop } \\
\text { (cc at STP) }\end{array}$ & $\begin{array}{l}\text { Total } \mathrm{O}_{2} \\
\text { Charged to Loop } \\
\text { Less } \mathrm{O}_{2} \text { Withdrawn } \\
\text { in Sampling } \\
\text { (cc at STP) }\end{array}$ & $\begin{array}{c}\mathrm{O}_{2} \text { Volume } \\
\text { at Time of } \\
\text { Sample } \\
\text { (cc at STP) }\end{array}$ & $\begin{array}{c}\mathrm{O}_{2} \\
\text { Consumed } \\
\text { Since Last } \\
\text { Sample } \\
\text { (cc at STP) }\end{array}$ & $\begin{array}{c}\text { Total } \mathrm{O}_{2}^{b} \\
\text { Consumed } \\
\text { (cc at STP) }\end{array}$ & $\begin{array}{c}\text { Calculated } \\
\text { Corrosion } \\
\text { Penetration } \\
\text { of Type } 347 \\
\text { Stainless Steel } \\
\text { (mils). }\end{array}$ \\
\hline \multirow{4}{*}{$\begin{array}{l}\text { Original } \mathrm{O}_{2} \text { fill GG-1 } \\
\text { started circulation }\end{array}$} & & 0 & 0 & 1165 & & 1165 & & 0 & 0 & 0 \\
\hline & & 0 & 0 & 0 & & 1165 & & 0 & 0 & 0 \\
\hline & GG-1-62 & 0 & 45.2 & 0 & 5 & 1160 & & 0 & 0 & 0 \\
\hline & GG.1-63 & 0 & 47.2 & 0 & 5 & 1155 & & 0 & 0 & 0 \\
\hline \multirow[t]{7}{*}{ Reactor on } & & 0 & 76.1 & 0 & & 1155 & & 0 & 0 & 0 \\
\hline & GG-1-64 & 5.2 & 77.8 & 0 & 6 & 1149 & & 49 & 48 & 0.003 \\
\hline & GG-1.65 & 12.2 & 80.1 & 0 & 4 & 1145 & & 62 & 111 & 0.006 \\
\hline & GG-1-66 & 21.4 & 83.1 & 0 & 4 & 1141 & & 81 & 192 & 0.01 \\
\hline & GG $1-67$ & 27.9 & 85.3 & 0 & 4 & 1138 & & 59 & 251 & 0.01 \\
\hline & $G G=1-68$ & 67.6 & 98.6 & 0 & 3 & 1135 & & 358 & 609 & 0.03 \\
\hline & & 68.7 & 100.6 & 0 & & 1135 & 471 & & 663 & \\
\hline \multirow[t]{3}{*}{$\mathrm{O}_{2}$ addition $\mathrm{GG}-2$} & & 68.7 & 100.6 & 1521 & & 2656 & 1993 & & 663 & \\
\hline & GG-1-69 & 120.6 & 120.6 & 0 & 8 & 2648 & & 576 & 1185 & 0.06 \\
\hline & & $\cdot$ & 151.7 & 0 & & 2648 & 647 & & 2000 & \\
\hline \multirow[t]{4}{*}{$\mathrm{O}_{2}$ addition $\mathrm{GG}-3$} & & & 151.7 & 985 & & 3633 & 1632 & & 2000 & \\
\hline & GG-1.70 & 253.6 & 169.2 & 0 & 5 & 3628 & & 1089 & 2274 & 0.12 \\
\hline & GG $=1-71$ & 309.2 & 190.8 & 0 & 3 & 3625 & & 352 & 2626 & 0.14 \\
\hline & & & 193.3 & 0 & & 3625 & 949 & & 2675 & \\
\hline \multirow[t]{2}{*}{$\mathrm{O}_{2}$ addition $\mathrm{GG}-4$} & & & 193.3 & 740 & & 4365 & 1689 & & 2675 & \\
\hline & $G G-1-72$ & 427.5 & 239.5 & 0 & 3 & 4365 & 1400 & 338 & 2964 & 0.16 \\
\hline
\end{tabular}


Table 23 (continued)

\begin{tabular}{|c|c|c|c|c|c|c|c|c|c|c|}
\hline Remarks & $\begin{array}{l}\text { Sample } \\
\text { Number }\end{array}$ & $\begin{array}{l}\text { LITR } \\
\text { Energy } \\
\text { (Mwhr) }\end{array}$ & $\begin{array}{l}\text { Total } \\
\text { Solution } \\
\text { Circulation } \\
\text { Time } \\
\text { (hr) }\end{array}$ & $\begin{array}{c}\mathrm{O}_{2} \\
\text { Additions } \\
\text { to Loop } \\
\text { (cc at STP) }\end{array}$ & $\begin{array}{c}\mathrm{O}_{2} \\
\text { Withdra wn } \\
\text { from Loop } \\
\text { (cc at STP) }\end{array}$ & $\begin{array}{c}\text { Total } \mathrm{O}_{2} \\
\text { Charged to Loop } \\
\text { Less } \mathrm{O}_{2} \text { Withdrawn } \\
\text { in Sampling } \\
\text { (cc at STP) }\end{array}$ & $\begin{array}{l}\mathrm{O}_{2} \text { Volume } \\
\text { at Time of } \\
\text { Sample } \\
\text { (cc at STP) }\end{array}$ & $\begin{array}{c}\mathrm{O}_{2} \\
\text { Consumed } \\
\text { Since Last } \\
\text { Sample } \\
\text { (cc at STP) }\end{array}$ & $\begin{array}{c}\text { Total }{ }_{2} \mathrm{O}^{b} \\
\text { Con sumed } \\
\text { (cc at STP) }\end{array}$ & $\begin{array}{c}\text { Calculated } \\
\text { Corrosion } \\
\text { Penetration } \\
\text { of Type } 347 \\
\text { Stainless Steel } \\
\text { (mils) }\end{array}$ \\
\hline \multirow{4}{*}{$\mathrm{O}_{2}$ addition $\mathrm{GG}-4$} & GG-1.73 & 518.1 & 269.7 & 0 & 3 & 4362 & 1269 & 128 & 3092 & 0.17 \\
\hline & & & 310.0 & 0 & & 4359 & 1091 & & 3268 & \\
\hline & $G G=1-74$ & 719.8 & 337.3 & 0 & 3 & 4359 & 1039 & 228 & 3320 & 0.18 \\
\hline & & & 360.8 & 0 & & 4356 & 991 & & 3364 & \\
\hline \multirow[t]{12}{*}{$\mathrm{O}_{2}$ addition $\mathrm{GG}-5$} & & & 360.8 & 707 & & 5064 & 1699 & & 3364 & \\
\hline & $G G=1-75$ & 774.7 & 365.3 & 0 & 4 & 5064 & 1680 & 63 & 3383 & 0.18 \\
\hline & $G G-1-76$ & 949.6 & 433.1 & 0 & 4 & 5060 & 1456 & 220 & 3603 & 0.19 \\
\hline & GG-1-77 & 1156.6 & 504.9 & 0 & 4 & 5056 & 1263 & 189 & 3792 & 0.20 \\
\hline & GG-1-78 & 1289.3 & 553.0 & 0 & 4 & 5051 & 1158 & 201 & 3893 & 0.21 \\
\hline & GG-1-79 & 1567.8 & 603.5 & 0 & 4 & 5048 & 1055 & 99 & 3992 & 0.21 \\
\hline & $G G=1-80$ & 1638.0 & 678.4 & 0 & 3 & 5045 & 906 & 146 & .4138 & 0.22 \\
\hline & $G G-1-81$ & 1802.2 & 721.0 & 0 & 2 & 5042 & 844 & 59 & 4197 & 0.22 \\
\hline & $G G=1-82$ & 1949.2 & 769.0 & 0 & 2 & 5040 & 777 & 165 & 4262 & 0.23 \\
\hline & GG-1-83 & 2155.9 & 842.5 & 0 & 1 & 5039 & 711 & 65 & 4327 & 0.23 \\
\hline & $G G=1-84$ & 2268.0 & 894.2 & 0 & 1 & 5038 & 661 & 49 & 4376 & 0.23 \\
\hline & GG-1-85 & 2394.1 & 936.6 & 0 & 1 & 5037 & 623 & 38 & 4414 & 0.24 \\
\hline \multirow[t]{2}{*}{$\mathrm{O}_{2}$ addition $\mathrm{GG} \cdot 6$} & & & 942.2 & 915 & 0 & 5951 & 1533 & & 4417 & \\
\hline & $G G=1-86$ & 2579.6 & 1009.5 & 0 & -3 & 5948 & 1218 & 315 & 4729 & 0.25 \\
\hline Shut down reactor & GG-1.87 & 2676.4 & 1057.8 & 0 & 0 & 5948 & 1088 & 130 & 4859 & 0.26 \\
\hline Shut down pump & End of run & 2676.4 & 1063.7 & 0 & 0 & 5948 & 1072 & 16 & 4875 & 0.26 \\
\hline
\end{tabular}

${ }^{a}$ Calculated amount removed as $\mathrm{O}_{2}$ dissolved in sample.

${ }^{b} 14.8 \mathrm{cc}$ at STP/psi. 
Table 24. Oxygen Consumption in Loop L-4-12

\begin{tabular}{|c|c|c|c|c|c|c|c|c|c|c|}
\hline Remarks & $\begin{array}{l}\text { Sample } \\
\text { Number }\end{array}$ & $\begin{array}{c}\text { LITR } \\
\text { Energy } \\
\text { (Mwhr) }\end{array}$ & $\begin{array}{l}\text { Total } \\
\text { Solution } \\
\text { Circulation } \\
\text { Time } \\
\text { (hr) }\end{array}$ & $\begin{array}{c}\mathrm{O}_{2} \\
\text { Additions } \\
\text { to Loop } \\
\text { (cc at STP) }\end{array}$ & $\begin{array}{c}\mathrm{O}_{2} \\
\text { Withdrawn } \\
\text { from Loof } \\
\text { (cc at STP) }\end{array}$ & $\begin{array}{c}\text { Total } \mathrm{O}_{2} \\
\text { Charged to Loop } \\
\text { Less } \mathrm{O}_{2} \text { Withdrawn } \\
\text { in Sampling } \\
\text { (cc at STP) }\end{array}$ & $\begin{array}{l}\mathrm{O}_{2} \text { Volume } \\
\text { at Time of } \\
\text { Sample } \\
\text { (cc at STP) }\end{array}$ & $\begin{array}{c}\mathrm{O}_{2} \\
\text { Consumed } \\
\text { Since Last } \\
\text { Sample } \\
\text { (cc at STP) }\end{array}$ & $\begin{array}{c}\text { Total } \mathrm{O}_{2}^{b} \\
\text { Consumed } \\
\text { (cc at STP) }\end{array}$ & $\begin{array}{c}\text { Calculated } \\
\text { Corrosion } \\
\text { Penetration } \\
\text { of Type } 347 \\
\text { Stainless Steel } \\
\text { (mils) }\end{array}$ \\
\hline \multicolumn{11}{|c|}{ Operation with lst enriched solution } \\
\hline \multirow{4}{*}{$\mathrm{C}_{2}$ additicn $(\mathrm{L}-4-12-3)$} & & 0 & 0 & 1420 & 0 & 1420 & 1420 & 0 & 0 & 0 \\
\hline & $L-4-12-1$ & 0 & 84.9 & 0 & 0 & 1420 & 1191 & 230 & 230 & 0.01 \\
\hline & $L-4-12-2$ & 55.0 & 143.0 & 0 & 1 & 1419 & 1049 & 140 & 370 & 0.02 \\
\hline & $L-4-12-3$ & 163.0 & 215.0 & 0 & 8 & 1411 & 880 & 161 & $\$ 31$ & 0.03 \\
\hline \multirow[t]{7}{*}{$\mathrm{O}_{2}$ addition (L-4-12-4) } & & & & 717 & 6 & 2122 & 1517 & & & \\
\hline & $L-4 \cdot 12-4$ & 191.5 & 262.1 & 0 & 0 & 2122 & 1434 & 157 & 688 & 0.04 \\
\hline & $L \cdot 4-12-5$ & 191.5 & 295.3 & 0 & 11 & 2111 & 1302 & 121 & 809 & 0.04 \\
\hline & $L-4-12-6$ & 229.2 & 311.0 & 0 & 10 & 2101 & .1255 & 37 & 846 & 0.05 \\
\hline & $L=4-12-7$ & 442.3 & 383.3 & 0 & 9 & 2092 & 1057 & 189 & 1035 & 0.06 \\
\hline & $L-4-12-8$ & 500.7 & 430.9 & 0 & 8 & 2084 & 949 & 100 & 1135 & 0.06 \\
\hline & $L-4-12-9$ & 623.9 & 479.9 & 0 & 7 & 2077 & 811 & 131 & 1266 & 0.07 \\
\hline \multirow[t]{3}{*}{$\mathrm{O}_{2}$ addition (L-4-12-5) } & & & & 786 & 6 & 2857 & 1423 & & & \\
\hline & $L=4-12-10$ & 921.1 & 598.6 & 0 & 0 & 2857 & 1410 & 181 & 1447 & 0.08 \\
\hline & $L-4-12-11$ & 1056.4 & 648.2 & 0 & 11 & 2846 & 1226 & 173 & 1620 & 0.09 \\
\hline . & $L-4-12-12$ & 1259.3 & 718.7 & 0 & 10 & 2836 & 1059 & 157 & 1777 & 0.10 \\
\hline Pump off & & 1310.2 & 772.9 & 0 & 8 & 2828 & 857 & 194 & 1971 & 0.11 \\
\hline Solution drain & & 1310.2 & 772.9 & 0 & 857 & 1971 & & & & \\
\hline \multicolumn{11}{|c|}{ Operation with $2 \mathrm{~d}$ enriched solution } \\
\hline \multirow[t]{6}{*}{$\mathrm{O}_{2}$ addition (L-4-12-7) } & & & & 1403 & 0 & 3374 & 1403 & & & \\
\hline & $L-4-12 \cdot 13$ & 1310.2 & 774.7 & 0 & 0 & 3374 & 1395 & 8 & 1979 & 0.11 \\
\hline & $L=4-12 \cdot 14$ & 1427.0 & 831.0 & 0 & 4 & 3370 & 1160 & 231 & 2210 & 0.12 \\
\hline & $L-4-12-15$ & 1519.5 & $878 . \dot{4}$ & 0 & 7 & 3363 & 992 & 161 & 2371 & 0.13 \\
\hline & $L=4-12-16$ & 1654.7 & 926.3 & 0 & 6 & 3357 & 856 & 130 & 2501 & 0.14 \\
\hline & $L-4 \cdot 12 \cdot 17$ & 1864.5 & 998.5 & 0 & 6 & 3351 & 666 & 184 & 2685 & 0.15 \\
\hline \multirow[t]{8}{*}{$\mathrm{O}_{2}$ addition $(\mathrm{L}-4-12-8)$} & & & & 1062 & 4 & 4409 & 1682 & & & \\
\hline & L-4-12-18 & 1922.5 & 1046.0 & 0 & 0 & 4409 & 1615 & 109 & 2794 & 0.15 \\
\hline & L-4-12-19 & 2263.4 & 1166.0 & 0 & 11 & 4398 & 1256 & 348 & 3142 & 0.17 \\
\hline & $L=4 \cdot 12-20$ & 2312.9 & 1214.3 & 0 & 9 & 4389 & 1130 & 117 & 3259 & 0.18 \\
\hline & L-4-12-21 & 2418.5 & 1262.0 & 0 & 8 & 4381 & 1002 & 120 & 3379 & 0.18 \\
\hline & L-4-12-22 & 2619.6 & 1334.0 & 0 & 7 & 4374 & 849 & 146 & 3525 & 0.19 \\
\hline & $L \cdot 4 \cdot 12-23$ & 2736.8 & 1382.3 & 0 & 6 & 4368 & 758 & 85 & 3610 & 0.19 \\
\hline & $\mathrm{L}-4 \cdot 12-24$ & 3086.7 & 1503.0 & 0 & 5 & 4363 & 612 & 141 & 3751 & 0.20 \\
\hline \multirow[t]{4}{*}{$\mathrm{O}_{2}$ addition (L-4-12-9) } & & & & 948 & 4 & 5307 & 1529 & & & \\
\hline & $L-4-12-25$ & 3591.1 & 1720.4 & 0 & 0 & 5307 & 1215 & 331 & 4092 & 0.22 \\
\hline & L- $4-12-26$ & 3936.8 & 1838.7 & 0 & 8 & 5299 & 1072 & 135 & 4227 & 0.23 \\
\hline & $L-4=12-27$ & 4357.6 & 2006.7 & 0 & 7 & 5292 & 862 & 203 & 4430 & 0.24 \\
\hline
\end{tabular}

cCalculated amount removed as $\mathrm{O}_{2}$ dissolved in sample.

${ }^{b} 12.8 \mathrm{cc}$ at STP/psi. 
Toble 25. Oxygen Consumption in Loop L-4-13

\begin{tabular}{|c|c|c|c|c|c|c|c|c|c|c|}
\hline Remarks & $\begin{array}{l}\text { Sample } \\
\text { Number }\end{array}$ & $\begin{array}{c}\text { LITR } \\
\text { Energy } \\
\text { (Mwhr) }\end{array}$ & $\begin{array}{l}\text { Total } \\
\text { Solution } \\
\text { Circulation } \\
\text { Time } \\
\text { (hr) }\end{array}$ & $\begin{array}{c}\mathrm{O}_{2} \\
\text { Additions } \\
\text { to Loop } \\
\text { (cc at STP) }\end{array}$ & $\begin{array}{c}\mathrm{O}_{2} \\
\text { Withdrawn } \\
\text { from Loop } \\
\text { (cc at STP) }\end{array}$ & $\begin{array}{c}\text { Total } \mathrm{O}_{2} \\
\text { Charged to Loop } \\
\text { Less } \mathrm{O}_{2} \text { Withdrawn } \\
\text { in Sampling } \\
\text { (cc at STP) }\end{array}$ & $\begin{array}{l}\mathrm{O}_{2} \text { Volume } \\
\text { at Time of } \\
\text { Sample } \\
\text { (cc at STP) }\end{array}$ & $\begin{array}{c}\mathrm{O}_{2} \\
\text { Consumed } \\
\text { Since Last } \\
\text { Sample } \\
\text { (cc at STP) }\end{array}$ & $\begin{array}{c}\text { Total } \mathrm{O}_{2}^{b} \\
\text { Consumed } \\
\text { (cc at STP) }\end{array}$ & $\begin{array}{c}\text { Calculated } \\
\text { Corrosion } \\
\text { Penetration } \\
\text { of Type } 347 \\
\text { Stainless Steel } \\
\text { (mils) }\end{array}$ \\
\hline $\mathrm{O}_{2}$ addition $(\mathrm{L} \cdot 4-13-1)$ & & 0 & 0 & 776 & 0 & 776 & 776 & 0 & 0 & 0 \\
\hline \multirow[t]{3}{*}{$\mathrm{O}_{2}$ addition $(\mathrm{L}-4-13-2)$} & & 0 & 47 & 417 & 0 & 1193 & 1053 & 140 & 140 & 0.01 \\
\hline & $L-4-13-1$ & 0 & 72 & 0 & 5 & 1188 & 987 & 61 & 201 & 0.01 \\
\hline & $L-4-13-2$ & 114 & 114 & 0 & 4 & 1184 & 774 & 209 & 410 & 0.02 \\
\hline \multirow{3}{*}{$\mathrm{O}_{2}$ addition $(\mathrm{L}-4-13-3)$} & & & 174 & 745 & 0 & 1929 & 1117 & 402 & 812 & 0.04 \\
\hline & $L \cdot 4-13 \cdot 3$ & 310 & 186 & 0 & 5 & 1924 & 1000 & 112 & 924 & 0.04 \\
\hline & $L-4-13-4$ & 424 & 234 & 0 & 4 & 1920 & 745 & 251 & 1175 & 0.06 \\
\hline \multirow[t]{6}{*}{$\mathrm{O}_{2}$ addition (L-4-13-4) } & & & 255 & 681 & 0 & 2601 & 1341 & 85 & 1260 & 0.06 \\
\hline & $L=4-13-5$ & 554 & 282 & 0 & 14 & 2587 & 1220 & 107 & 1367 & 0.06 \\
\hline & $L=4-13-6$ & 722 & 354 & 0 & 11 & 2576 & 952 & 257 & 1624 & 0.08 \\
\hline & $L-4-13-7$ & 778 & 402 & 0 & 10 & 2566 & 840 & 102 & 1726 & 0.08 \\
\hline & $L-4-13-8$ & 887 & 450 & 0 & 8 & 2558 & 719 & 113 & 1839 & 0.09 \\
\hline & $L=4-13-9$ & 1096 & 522 & 0 & 6 & 2552 & 551 & 162 & 2001 & 0.09 \\
\hline Loss from system & & & & 0 & 39 & 2513 & 436 & 76 & 2077 & 0.10 \\
\hline \multirow{6}{*}{$\mathrm{O}_{2}$ addition (L-4-13-5-B) } & & & 553 & 966 & 0 & 3479 & 1402 & 0 & 2077 & 0.10 \\
\hline & $L=4-13-10$ & 1275 & 618 & 0 & 10 & 3469 & 1249 & 143 & 2220 & 0.10 \\
\hline & $L=4-13-11$ & 1481 & 690 & 0 & 9 & 3460 & 1082 & 158 & 2378 & 0.11 \\
\hline & $L-4-13-12$ & 1590 & 738 & 0 & 9 & 3451 & 887 & 186 & 2564 & 0.12 \\
\hline & $L=4-13-13$ & 1734 & 786 & 0 & 7 & 3444 & 768 & 112 & 2676 & 0.13 \\
\hline & $L=4-13-14$ & 1947 & 858 & 0 & 6 & 3438 & 625 & 137 & 2813 & 0.13 \\
\hline \multirow[t]{4}{*}{$\mathrm{O}_{2}$ addition (L-4-13-6) } & & & 886 & 1197 & 0 & 4635 & 1768 & 54 & 2867 & 0.13 \\
\hline & $L=4-13-15$ & 2055 & 931 & 0 & 16 & 4619 & 1572 & 180 & 3047 & 0.14 \\
\hline & $L-4-13-16$ & 2322 & 1028 & 0 & 13 & 4606 & 1268 & 291 & 3338 & 0.16 \\
\hline & $L-4-13-17$ & 2328 & & & & & & & & \\
\hline Before loop drain & & & 1042 & 0 & & 4606 & 1234 & 34 & 3372 & 0.16 \\
\hline
\end{tabular}

${ }^{a}$ Calculated amount removed as $\mathrm{O}_{2}$ dissolved in sample.

b $14.1 \mathrm{cc}$ at STP/psi. 
Table 26. Oxygen Consumption in Loop L-4-18

\begin{tabular}{|c|c|c|c|c|c|c|c|c|c|c|}
\hline Remarks & $\begin{array}{l}\text { Sample } \\
\text { Number }\end{array}$ & $\begin{array}{l}\text { LITR } \\
\text { Energy } \\
\text { (Mwhr) }\end{array}$ & $\begin{array}{l}\text { Total } \\
\text { Solution } \\
\text { Circulation } \\
\text { Time } \\
\text { (hr) }\end{array}$ & $\begin{array}{c}\mathrm{O}_{2} \\
\text { Additions } \\
\text { to Loop } \\
\text { (ce at STP) }\end{array}$ & $\begin{array}{c}\mathrm{O}_{2} \\
\text { Withdrawn } \\
\text { from Loop } \\
\text { (cc at STP) }\end{array}$ & $\begin{array}{c}\text { Total } \mathrm{O}_{2} \\
\text { Charged to Loop } \\
\text { Less } \mathrm{O}_{2} \text { Withdrawn } \\
\text { in Sampling } \\
\text { (cc at STP) }\end{array}$ & $\begin{array}{l}\mathrm{O}_{2} \text { Volume } \\
\text { at Time of } \\
\text { Sample } \\
\text { (cc at STP) }\end{array}$ & $\begin{array}{c}\mathrm{O}_{2} \\
\text { Consumed } \\
\text { Since Last } \\
\text { Sample } \\
\text { (cc at STP) }\end{array}$ & $\begin{array}{c}\text { Total } \mathrm{O}_{2}{ }^{b} \\
\text { Consumed } \\
\text { (cc at STP) }\end{array}$ & $\begin{array}{c}\text { Calculated } \\
\text { Corrosion } \\
\text { Penetration } \\
\text { of Type } 347 \\
\text { Stainless Steel } \\
\text { (mils) }\end{array}$ \\
\hline Original $\mathrm{O}_{2}$ fill & & 0 & 0 & 0 & 0 & 365 & 365 & 0 & 0 & 0. \\
\hline \multirow{3}{*}{$\mathrm{O}_{2}$ addition ( $\left.\mathrm{L}-4-18-1\right)$} & & 0 & 0 & 837 & 0 & 1202 & 1202 & 0 & 0 & 0 \\
\hline & & 0 & 5 & 0 & 0 & 1202 & 1159 & 43 & 43 & 0.001 \\
\hline & $L-4-18-1$ & 0 & 43.8 & 0 & 5 & 1197 & 579 & 575 & 618 & 0.03 \\
\hline \multirow{13}{*}{$\mathrm{O}_{2}$ addirion (L-4-18-2) } & & 0 & 45.4 & 726 & 0 & 1923 & 1302 & 3 & 621 & 0.03 \\
\hline & $L=4-18=2$ & 111.4 & 100.2 & & 5 & 1918 & 1230 & 67 & 688 & 0.03 \\
\hline & & 115.0 & 108.8 & & 0 & 1918 & 1216 & 14 & 702 & 0.03 \\
\hline & & 259.4 & 150.0 & . & 0 & 1918 & 1158 & 58 & 760 & 0.04 \\
\hline & & 358.8 & 190.0 & & $0^{\circ}$ & 1918 & 1102 & 56 & 816 & 0.04 \\
\hline & & 441.3 & 223.0 & & 0 & 1918 & 1035 & 67 & 883 & 0.04 \\
\hline & & 521.1 & 250.0 & & 0 & 1918 & 1008 & 27 & 910 & 0.04 \\
\hline & . & 632.1 & 280.0 & & 0 & 1918 & 980 & 28 & 938 & 0.04 \\
\hline & & 674.6 & 301.5 & & 0 & 1918 & 957 & .23 & 961 & 0.05 \\
\hline & & 727.1 & 320.0 & & 0 & 1918 & 952 & 5 & 966 & 0.05 \\
\hline & & 773.6 & 340.0 & & 0 & 1918 & 943 & 9 & 975 & 0.05 \\
\hline & & 821.6 & 356.5 & & 0 & 1918 & 933 & 10 & 985 & 0.05 \\
\hline & $L=4-18-3$ & 837.6 & 388.1 . & & 5 & 1913 & 893 & 35. & 1020 & 0.05 \\
\hline \multirow{20}{*}{ 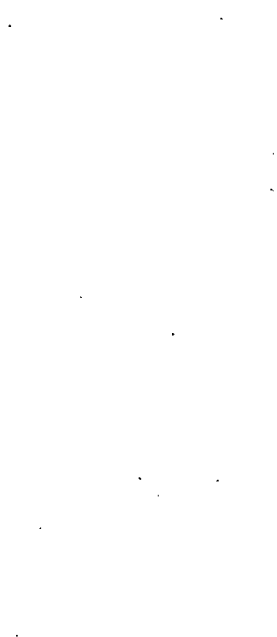 } & & 837.6 & $410.0^{\circ}$ & & 0 & 1913 & 864 & 29 & 1049 & 0.05 \\
\hline & $L-4-18-4$ & 837.6 & 436.6 & & 4 & 1909 & 828 & 32 & 1081 & 0.05 \\
\hline & & 837.6 & 456.3 & & 0 & 1909 & 800 & 28 & 1109 & 0.05 \\
\hline & & 859.8 & 464.3 & & 0 & 1909 & 792 & 8 & 1117 & 0.05 \\
\hline & & 923.9 & 490.0 & & 0 & 1909 & 768 & 24 & 1141 & 0.05 \\
\hline & $L=4-18-5$ & 978.2 & 508.1 & . & 4 & 1905 & 751 & 13 & 1154 & 0.05 \\
\hline & & 1043.9 & 530.0 & & 0 & 1905 & 730 & 21 & 1175 & 0.06 \\
\hline & & 1118.9 & 555.0 & & 0 & 1905 & 708 & 22 & 1197 & 0.06 \\
\hline & L-4-18-6 & 1160.8 & 580.1 & & 4 & 1901 & 684 & 20 & 1217 & 0.06 \\
\hline & & 1220.5 & 600.0 & & 0 & 1901 & 665 & 19 & 1236 & 0.06 \\
\hline & & 1227.4 & 625.0 & & 0 & 1901 & 650 & 15 & 1251 & 0.06 \\
\hline & & 1302.4 & 650.0 & . & 0 & 1901 & 634 & 16 & 1267 & 0.06 \\
\hline & $L-4-18-7$ & 1441.0 & 676.0 & & 3 & 1898 & 618 & 13 & 1280 & 0.06 \\
\hline & & 1507.0 & 698.0 & & 0 & 1898 & 605. & 13 & 1293 & 0.06 \\
\hline & & 1508.0 & 713.2 & & 0 & 1898 & 599 & 6 & 1299 & 0.06 \\
\hline & L-4-18-8 & 1605.0 & 748.3 & & 3 & 1895 & 572 & 24 & 1323 & 0.06 \\
\hline & & $\cdot 1630.0$ & 775.0 & & 0 & 1895 & 549 & 23 & 1346 & 0.06 \\
\hline & & 1645.0 & 800.0 & & 0 & 1895 & 529 & 20 & 1366 & 0.06 \\
\hline & & 1690.0 & 825.0 & & 0 & 1895 & 508 & 21 & 1387 & 0.06 \\
\hline & $L-4 \cdot 18-9$ & 1807.7 & 844.1 & & 3 & 1892 & 493 & 12 & 1399 & 0.07 \\
\hline Pump failure & & 1926.2 & 859.6 & & 0 & 1892 & 482 & 11 & 1410 & 0.07 \\
\hline Solution drained & & 1926.2 & 859.6 & & 482 & 1410 & 0 & 0 & 1410 & 0.07 \\
\hline
\end{tabular}

${ }^{a}$ Calculated amount removed as $\mathrm{O}_{2}$ dissolved in sample.

b $11.1 \mathrm{cc}$ at STP/psi. 


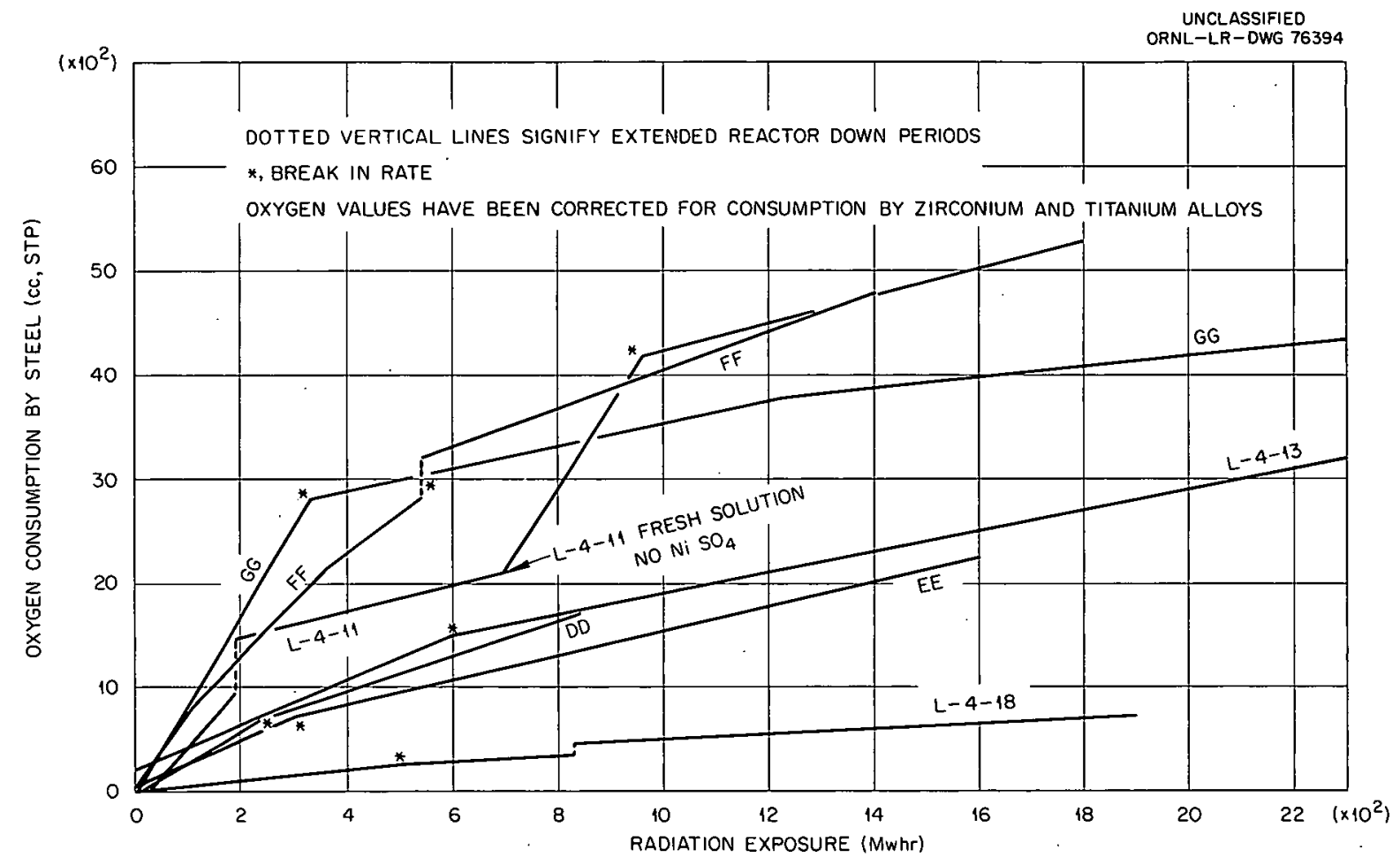

Fig. 30. Total Oxygen Consumption by Stainless Steel Corrosion vs Radiation Exposure.

\subsection{Radiolytic-Gas Pressure}

Average radiolytic-gas pressures in the pressurizers of the experiments at $3-\mathrm{Mw}$ reactor power, calculated from pressurizer pressure-temperature measurements before and after reactor shutdowns, are listed in Table 27. These were used to calculate the copper rate constants in the different test solutions by the method previously described ${ }^{7}$ and the equation reproduced here:

$$
\left[\mathrm{H}_{2}\right] *=\frac{K_{1}\left(R^{1} / V_{e}\right) E}{B\left(K_{m}[\mathrm{Cu}] / 3600\right)^{2}+\left(K_{m}[\mathrm{Cu}] / 3600\right)\left[B\left(R^{1} / V_{m}\right)+R^{1} / V_{e}\right]+\left[\left(R^{1}\right)^{2} / V_{m} V_{e}\right](1-L E)} .
$$

Values for the several factors employed in the calculations are also listed in Table 27. The fissionpower values are those determined from $\mathrm{Cs}^{137}$ analyses as described in Sec 2 and were used to calculate $K_{1}$, the rate of $\mathrm{H}_{2}$ formation in the mainstream solution, using a $G_{\mathrm{H}_{2}}$ value of 1.5 . The solubility constants for $\mathrm{O}_{2}\left(a^{\prime}\right)$ and $\mathrm{H}_{2}$ or $\mathrm{D}_{2}(a)$ in the pressurizer solutions were obtained from a compilation of Battelle and ORNL solubility data by Banter. ${ }^{8}$ The copper concentrations are those for the solutions as charged.

${ }^{7}$ G. H. Jenks and J. E. Baker, Apparent Copper Rate Constants Determined in In.Pile Loop Experiment L-2-22, ORNL CF-60-3-88 (Mar. 23, 1960).

${ }^{8} \mathrm{~J}$. C. Banter, private communication. 
Table 27. Apparent Copper Molar Rate Constants

\begin{tabular}{|c|c|c|c|c|c|c|c|c|c|c|c|c|c|}
\hline Loop & $\begin{array}{l}\text { Radiolytic- } \\
\text { Gas Pressure } \\
\text { in Pressurizer } \\
\text { (psi) }\end{array}$ & $\begin{array}{c}\mathrm{p}^{a} \\
\text { Fission } \\
\text { Power } \\
\text { (w) }\end{array}$ & $\begin{array}{c}\mathrm{a}_{1} \\
\mathrm{H}_{2} \text { or } \mathrm{D}_{2} \\
\text { Solubility } \\
\text { at Pressurizer } \\
\text { Temperauture } \\
\text { (psi liter } \\
-1 \text { cc }^{-1} \text { ) }\end{array}$ & $\begin{array}{c}a^{\prime} \\
\mathrm{O}_{2} \text { Solubility } \\
\text { at Pressurizer } \\
\text { Temperature } \\
\left.\text { (psi liter }{ }^{-1} \mathrm{cc}^{-1}\right)\end{array}$ & $\begin{array}{l}R^{\prime} \\
\text { Flow Rate } \\
\text { Through } \\
\text { Pressurizer } \\
\text { (liters/sec) }\end{array}$ & $\begin{array}{c}V e, \\
\text { Solution } \\
\text { Volume } \\
\text { in Pressurizer } \\
\text { (liters) }\end{array}$ & $\begin{array}{c}V_{m} \\
\text { Solution } \\
\text { Volume } \\
\text { in Pressurizer } \\
\text { (liters) }\end{array}$ & $\begin{array}{c}L^{b} \\
\text { Factor for } \\
\text { Recombination } \\
\text { of Radiolytic } \mathrm{H}_{2} \\
\text { or } \mathrm{D}_{2} \text { and } \mathrm{O}_{2} \text { in } \\
\text { Ptessurizer Exit } \\
\left(e^{-K_{s}^{\prime} t^{\prime}}\right)\end{array}$ & $\begin{array}{c}E^{b}, \\
\text { Facror for } \\
\text { Recombination } \\
\text { of Radiolytic } \mathrm{H}_{2} \\
\text { or } \mathrm{D}_{2} \text { and } \mathrm{O}_{2} \text { in } \\
\text { Pressurizer Enctrance Line } \\
\left(e^{-K_{s}^{\prime \prime} t^{\prime \prime}}\right)\end{array}$ & $\begin{array}{c}\text { [Cu], } \\
\text { Copper Concentrations }{ }^{c} \\
\text { in Solution } \\
\text { Originally Charged } \\
\text { to Loop } \\
(M)\end{array}$ & 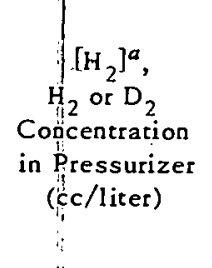 & $\begin{array}{c}\mathrm{H}_{2} \text { or } \mathrm{D}_{2} \\
\text { Concentration } \\
\text { in Mainstream } \\
\text { (cc/liter) }\end{array}$ & $\begin{array}{c}K_{m}^{d}{ }^{d} \\
\text { Apparent Copper } \\
\text { Molar Rate Constant } \\
\text { at Mainstream } \\
\text { Temperatures } \\
\text { (liters mole } \\
\text { (it hr }{ }^{-1} \text { ) }\end{array}$ \\
\hline DD & 7.5 & 437 & 0.429 & 0.298 & 0.0051 & 0.241 & 0.644 & 0.956 & 0.854 & 0.030 & 19.0 & 75.6 & 2,500 \\
\hline FF & 9.4 & 606 & 0.429 & 0.298 & 0.0035 & 0.228 & 0.656 & 0.936 & 0.796 & 0.028 & 23.8 & 112.6 & 2,400 \\
\hline GG & 13 & 829 & 0.429 & 0.298 & 0.0035 & 0.204 & 0.655 & 0.937 & 0.798 & 0.027 & 32.9 & 157.3 & 2,850 \\
\hline $\mathrm{EE}$ & 4.8 & 528 & 0.429, & 0.298 & 0.0034 & 0.252 & 0.621 & 0.934 & 0.788 & 0.028 & 12.1 & 80.3 & 3,180 \\
\hline $\mathrm{L}-4-12$ & 10.6 & 730 & 0.429 & 0.298 & 0.0059 & 0.181 & 0.731 & 0.962 & 0.872 & 0.032 & 26.8 & 94.0 & 3,010 \\
\hline$L=4-13$ & 15.1 & 689 & 0.280 & 0.254 & 0.0042 & 0.293 & 0.795 & 0.958 & 0.884 & 0.034 & 39.1 & 165.8 & 1,600 \\
\hline$L-4-18$ & 10.8 & 700 & 0.322 & 0.268 & 0.0049 & 0.285 & 0.675 & 0.946 & 0.826 & 0.068 & 23.7 & 114.6 & 1,080 \\
\hline $\begin{array}{r}a_{B a s} \\
b_{K} \\
b_{s} \\
c_{H} H_{2} \\
d_{\text {Niai }} 2 \\
\text { Note: } A\end{array}$ & $\begin{array}{l}\text { sed on } \mathrm{Cs}^{137} \text { ana } \\
\text { and } t^{\circ} \text { are, respe } \\
\text { owas the solvent } \\
\text { instream and pres } \\
\text { Il volumes and } c\end{array}$ & $\begin{array}{l}\text { lyses and } \\
\text { ctively, th } \\
\text { in all exp } \\
\text { surizer ten } \\
\text { oncentratio }\end{array}$ & $\begin{array}{l}200 \mathrm{Mev} / \mathrm{fission} \text {. } \\
\text { estimated average } \\
\text { eriments except L-4- } \\
\text { peratures were } 250 \\
\text { as are (STP). }\end{array}$ & $\begin{array}{l}\text { rate constant in the } \\
13 \text { and } L-4-18 \text {, wher } \\
\text { and } 280^{\circ} \mathrm{C} \text {, respecti }\end{array}$ & $\begin{array}{l}\text { oressurizer exi } \\
\mathrm{D}_{2} \mathrm{O} \text { was emp } \\
\text { ely, for all exp }\end{array}$ & $\begin{array}{l}\text { line }\left(\sec ^{-1}\right) \text { and } \\
\text { loyed. } \\
\text { eriments except }\end{array}$ & $\begin{array}{l}\text { the residence tin } \\
-4 \cdot 18 \text {; temperatur }\end{array}$ & $\begin{array}{l}\text { ne in the line }(\mathrm{sec}), K_{s}^{\prime \prime} \\
\text { es for } \mathrm{L}-4-18 \text { were } 235 \text { a }\end{array}$ & $\begin{array}{l}\text { and } t^{\prime \prime} \text { are similarly defined } \mathrm{fa} \\
\text { nd } 265^{\circ} \mathrm{C} \text {. }\end{array}$ & tors for the entrance line. & . & & \\
\hline
\end{tabular}


Another factor employed in the calculation is the ratio $B$ of the rate constants in the pressurizer and mainstream. An activation energy of $22,000 \mathrm{kcal} / \mathrm{mole}$ for the copper activity was used to estimate these values:

The calculated values for the copper molar rate constant and the hydrogen concentration in the mainstream solutions are listed in the final columns of Table 27, and a plot of the rate-constant values is shown in Fig. 31. Also plotted is the molar rate constant $(9860)$ determined in the $280^{\circ} \mathrm{C}$ experiment $\mathrm{L}-2-$ $15^{9}\left(0.17 \mathrm{~m} \mathrm{UO}_{2} \mathrm{SO}_{4}\right.$ in $\left.\mathrm{H}_{2} \mathrm{O}\right)$.

${ }^{9}$ G. H. Jenks and J. E. Baker, HRP Radiation Corrosion Studies: In-Pile. Loops L-2.15 and L-4-16. ORNL-3099 (in preparation).

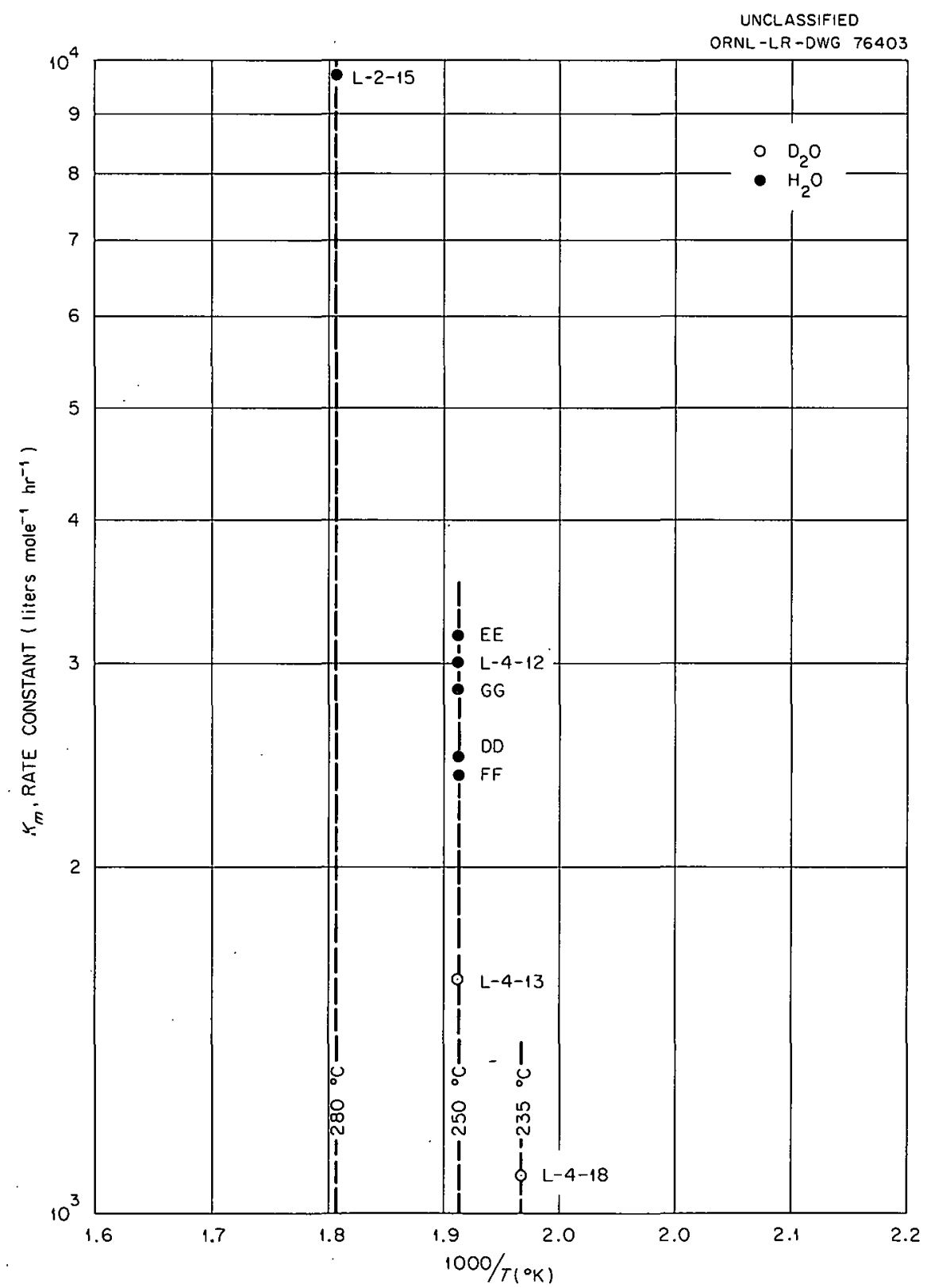

Fig. 31. Copper Molar Rate Constants vs Temperoture. 
The rate-constant values for $\mathrm{H}_{2} \mathrm{O}$ solutions at $250^{\circ} \mathrm{C}$ are in the range 2400 to 3200 liters mole $\mathrm{hr}^{-1}$ and are in reasonable agreement with those determined in out-of-pile loop tests. ${ }^{10}$ The constants in the experiments employing $\mathrm{D}_{2} \mathrm{O}$ solutions ( $\mathrm{L}-4-13$ and $L-4-18$ ) were below those measured or predicted for water solutions. Similar differences between $\mathrm{D}_{2} \mathrm{O}$ and $\mathrm{H}_{2} \mathrm{O}$ solutions have been reported by others. ${ }^{11}$

\subsection{Uranium Balance}

The method and results of estimating the balance between the amounts of charged and recovered uranium in each of the experiments are illustrated in Table 28. Uranium balance results for the seven experiments are shown in Table 29.

In all but two of these experiments, the amount of recovered uranium, determined as shown in the table, was somewhat greater than the charged amounts. These discrepancies are believed to have resulted mainly from errors in sampling the weigh-tank contents (nonrepresentative samples) and, to a lesser extent, from uncertainties in the total volumes of solution in the weigh tank. Thus the actual uranium recovery in a given experiment is uncertain, but there is no reason to believe that recovery was significantly incomplete in any of the experiments.

\subsection{Results of Qualitative Examination of Loops}

Results of qualitative inspection of loop and specimens for each experiment are given in the following paragraphs. A brief description of the surface appearance of the coupons is included in Tables $36-42$ and in Tables 30 and 31.

\subsubsection{Loop DD}

In general, the surfaces in all portions of the loop, with the exception of the forward or high-flux portion of the core, were covered with a very dark, dull scale. The nearly stagnant area on the outside of the inline holder and the high-velocity areas of the pump impeller and housing were covered with the same dull, black film.

The films from wetted areas of the pressurizer, as well as those from vapor-phase portions, were similar to those in other portions of the loop. However, they were somewhat browner than those in the loop. The demarcation line between solution-and vapor-phase regions became less and less distinct from the inlet to the outlet of the pressurizer. The film was darker at the outlet than at the inlet.

Obvious changes in film appearance were observed in the core. At the rear or low-flux portion the film had the same dull, black appearance found in the rest of the loop. From the core rear toward areas of higher flux, the nature of the film gradually changed. It appeared to become thinner, harder, and glossier. The forward third of the core was covered with a film which had the appearance of a very glossy, baked, black enamel. The film on the core cap had this appearance and a slightly blistered appearance in addition. However, it is likely that this blistered appearance resulted from the character of the surface before

${ }^{10}$ G. H. Jenks, letter to E. G. Bohlmann, "Data from Determination of $\mathrm{Cu}^{++}$in Out-of-Pile Loop Tests," Apr. $10,1958$.

${ }^{11}$ M. J. Kelly et al., HRP Quart. Progr. Rept. May 1-Oct. 31, 1959, ORNL-2879, pP 93-95. 
Table 28. Actual Uranium Balance in Experiment FF

\begin{tabular}{|c|c|c|c|c|c|}
\hline Source & $\begin{array}{l}\text { Solution } \\
\text { Weight } \\
\text { (g) }\end{array}$ & $\begin{array}{l}\text { Specific } \\
\text { Gravity }\end{array}$ & $\begin{array}{l}\text { Solution } \\
\text { Volume } \\
\text { (ml) }\end{array}$ & $\begin{array}{c}\text { Uranium Concentration } \\
\text { by Analysis } \\
(\mathrm{mg} / \mathrm{ml})\end{array}$ & $\begin{array}{l}\text { Weight } \\
\text { of Uranium } \\
\text { (g) }\end{array}$ \\
\hline \multicolumn{6}{|c|}{ Charged to Loop } \\
\hline Original solution charged to system & 1244 & 1,056 & 1178 & 40.0 & 47.0 \\
\hline Solution additions during operation & & & 220 & 40.0 & 8.8 \\
\hline Total & & & & & 55.8 \\
\hline \multicolumn{6}{|c|}{ Recovered from Loop } \\
\hline $\begin{array}{l}\text { From weigh tank a/ter sampling of } \\
\text { contents [sample purges and flushes } \\
\text { through sample } 50 \text { (b)] }\end{array}$ & $4470^{a}$ & $1.0^{b}$ & 4470 & 2.4 & 10.7 \\
\hline $\begin{array}{l}\text { From weigh tank after sampling of } \\
\text { contents (purges from samples } 52 \\
\text { and } 53 \text { plus loop contents and rinses) }\end{array}$ & $7530^{a}$ & $1.0^{b}$ & 7530 & 6.2 & 46.5 \\
\hline $\begin{array}{l}\text { Loop inventory samples sent to } \\
\text { laboratory }\end{array}$ & & & 77.3 & $40.0-36.4$ & 2.9 \\
\hline $\begin{array}{l}\text { Weigh tank samples sent to laboratory }{ }^{c} \\
\text { Samples } 51 \text { (a) and (b) [weigh tank } \\
\text { contents, sample purges, and flushes } \\
\text { through sample } 50 \text { (b)] }\end{array}$ & & & 2.1 & 2.4 & 0 \\
\hline $\begin{array}{l}\text { Samples } 54(\mathrm{a}) \text { and }(\mathrm{b}), 55,57 \text {, and } 58 \\
\text { [weigh tank contents, sample purges, } \\
\text { and flushes for samples following } 50 \\
\text { (b), plus inventory drained from loop } \\
\text { and loop rinses] }\end{array}$ & & & \multirow[t]{2}{*}{6.8} & \multirow[t]{2}{*}{6.2} & 0 \\
\hline Total & & & & & 60.1 \\
\hline \multirow{2}{*}{\multicolumn{6}{|c|}{$\begin{array}{l}{ }^{a} \text { From weigh tank reading. } \\
{ }^{b} \text { Assumed. } \\
c_{\text {Weigh tank was drained of sample purges and flushes after sample } 50 \text { (b). Therefore, final contents of tank in- }} \\
\text { cluded purges and flushes from samples } 52 \text { and } 53 \text { plus loop inventory and loop rinses. }\end{array}$}} \\
\hline & & & & & \\
\hline $\begin{array}{l}\text { Uranium } \\
\text { to Exp }\end{array}$ & $\begin{array}{l}\text { Charged } \\
\text { riment } \\
\text { ) }\end{array}$ & & \multicolumn{2}{|c|}{$\begin{array}{l}\text { Uranium Recovered } \\
\text { from Experiment } \\
\text { (g) }\end{array}$} & $\begin{array}{l}\text { Balance } \\
(\%)\end{array}$ \\
\hline $\mathrm{DD}$ & .5 & & \multicolumn{2}{|c|}{45.0} & +8.4 \\
\hline FF & 5.8 & & \multicolumn{2}{|c|}{60.1} & +7.7 \\
\hline GG & 1.7 & & \multicolumn{2}{|c|}{64.1} & +3.9 \\
\hline EE & 4.0 & & \multicolumn{2}{|c|}{52.9} & -2.4 \\
\hline $\mathrm{L}-4-12$ & .7 & & \multicolumn{2}{|c|}{138.4} & +6.7 \\
\hline L-4- 13 & 1.8 & & \multicolumn{2}{|c|}{78.8} & -3.6 \\
\hline$L-4-18$ & 6.0 & & \multicolumn{2}{|c|}{61.0} & +9.0 \\
\hline
\end{tabular}


Table 30. Summary of Metallographic Examination of Corrosion Coupons

\begin{tabular}{cccccc}
\hline & Average & Solution Fission- & & \\
Coupon & Solution & Coupon & Weight & \\
Number & $\begin{array}{c}\text { Velocity Across } \\
\text { Specimen } \\
\text { (fps) }\end{array}$ & $\begin{array}{c}\text { at } 3 \mathrm{Nw} \\
(\mathrm{w} / \mathrm{ml})\end{array}$ & $\begin{array}{c}\text { Thickness } \\
\text { (mils) }\end{array}$ & $\begin{array}{c}\text { Change } \\
\text { (mg) }\end{array}$ & Remarks \\
& & & & Number \\
\hline
\end{tabular}

Loop DD

Core-channel coupons

Type 347 SS

12

$446 A$

1.5

0.8

55.2

$-93.9$

"Shouldered" - slight attack at grain boundaries

-37.9 Many pits 2 to 3 mils in depth

$59.3-6.6$ A few shallow pits

In-line-channel coupons

Type 347 SS

$449 A$

Core-channel coupons

Zircaloy-2
$924 A$
$929 A$
$933 A$

In-line-channel coupons

$\begin{array}{ll}\text { Zircaloy-2 } & \\ 912 A & 13 \\ 917 A & 46\end{array}$

Core-channel coupons

Zircaloy-2

$\begin{array}{ll}948 A & 13 \\ 953 A & 46 \\ 957 A & 17\end{array}$

In-line-channel coupons

Zircaloy-2

$941 A$

$945 A$

-8.1 No evidence of localized or pitting type corrosive attack -4.8 No evidence of localized or pitting type corrosive attack

-3.4 No evidence of localized or pitting type corrosive attack

$60.9+0.8$ No evidence of localized or pitting type corrosive attack $59.8+1.3 \quad$ No evidence of localized or pitting type corrosive attack

\section{Loop GG}

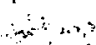

it: . tis

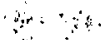

$\therefore$

$\therefore$

$+$

$+\cdots$

$\because \because \because$

$\begin{array}{rrl}59.0 & -16.5 & \text { Surface slightly roughened; 3-mil crack on one side } \\ 59.2 & -11.8 & \text { Entire surface smooth, no attack } \\ 60.0 & -9.3 & \text { Entire surface smooth, no attack }\end{array}$

55

$60.5+1.6$ Entire surface smooth; film not observable

$59.3 \quad-2.5 \quad$ Entire surface smooth; no attack

\section{Loop EE}

Core-channel coupons

Type 347 SS

$743 A$

$747 A$

12

$787 \mathrm{~A}$

LoP EE

Titanium-55A

$\begin{array}{ll}\mathrm{T}-8 & 10 \\ \mathrm{~T}-12 & 38 \\ \mathrm{~T}-16 & 12\end{array}$

Zircaloy-2

$\begin{array}{ll}Z-19 & 10 \\ Z-24 & 35 \\ Z-37 & 11\end{array}$

In-line-channel coupons

Type 347 SS

$740 A$

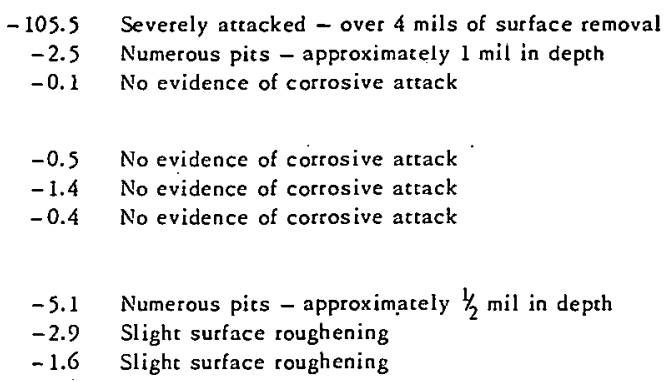

$+4.6^{a}$ A few pits - approximately $1 / 2 \mathrm{mil}$ in depth 
Table 30 (continued)

\begin{tabular}{|c|c|c|c|c|c|c|}
\hline $\begin{array}{l}\text { Coupon } \\
\text { Number }\end{array}$ & $\begin{array}{l}\text { Average } \\
\text { Solution } \\
\text { Velocity Across } \\
\text { Specimen } \\
\text { (fps) }\end{array}$ & $\begin{array}{l}\text { Solution Fission- } \\
\text { Power Density } \\
\text { at } 3 \wedge \mathrm{w} w \\
(w / \mathrm{ml})\end{array}$ & $\begin{array}{l}\text { Coupon } \\
\text { Thickness } \\
\text { (mils) }\end{array}$ & $\begin{array}{c}\text { Weight } \\
\text { Change } \\
\text { (mg) }\end{array}$ & Remarks & $\begin{array}{c}\text { Figure } \\
\text { Number }\end{array}$ \\
\hline \multicolumn{7}{|l|}{ Zircaloy-2 } \\
\hline Z-12 & 35 & & & $+6.0^{a}$ & No evidence of corrosive attack & \\
\hline \multicolumn{7}{|c|}{ Titanium-55A } \\
\hline \multirow[t]{2}{*}{ T3 } & 38 & & & $+4.9^{a}$ & No evidence of corrosive attack & \\
\hline & \multicolumn{6}{|c|}{ Loop L.4 12} \\
\hline \multicolumn{7}{|c|}{ Core-channel coupons } \\
\hline \multicolumn{7}{|c|}{ Type 347 SS } \\
\hline $292 \mathrm{~A}$ & 40 & 2.1 & 59.8 & -3.7 & $\begin{array}{l}\text { One side rough and uneven; one end severely attacked, } \\
5 \text {-mil variation }\end{array}$ & \\
\hline $996 \mathrm{~A}$ & 10 & 0.9 & 60.0 & -0.7 & Smooth on both sides and ends & \\
\hline \multicolumn{7}{|l|}{ Zircaloy-2 } \\
\hline Z-89 & 11 & 4.2 & 58.8 & -13.8 & Smooth over entire surface & \\
\hline $\mathrm{z}-92$ & 44 & 1.9 & 59.2 & -7.1 & Two isolated rough spors less than 1 mil deep, otherwise smooth & \\
\hline \multicolumn{7}{|c|}{ Titanium-55A } \\
\hline $\mathrm{Ti}-100$ & 9 & 4.8 & 59.4 & -2.1 & Smooth, no attack & \\
\hline $\mathrm{Ti}-103$ & 37 & 2.2 & 59.3 & -0.9 & Smooth, no attack & \\
\hline $\mathrm{Ti} \cdot 107$ & 12 & 1.1 & 58.6 & -0.1 & Smooth, no attack & \\
\hline \multicolumn{7}{|c|}{ In-line-channel coupons } \\
\hline \multicolumn{7}{|c|}{ Type 347 SS } \\
\hline $1121 \mathrm{~A}$ & 13 & & 59.9 & -1.2 & Sides smooth; one end attacked, 3-mil variation & \\
\hline $1126 A^{b}$ & 20 & & . & -107.5 & Smooth except near one end, up to 12 mils removed at end & 58 \\
\hline \multicolumn{7}{|l|}{ Inconel } \\
\hline $1125 \mathrm{~A}$ & 40 & & & -609.4 & Surface uneven, up to 40 mils general removal & \\
\hline \multicolumn{7}{|l|}{ Zircaloy-2 } \\
\hline$z-102^{c}$ & 15 & & 60.2 & & Sides smooth, all corners severely attacked & \\
\hline$Z \cdot 103^{c}$ & 11 & · & 61.1 & & Sides smooth, all corners severely attacked. & 59 \\
\hline \multicolumn{7}{|c|}{ Titanium-55A } \\
\hline $\mathrm{Ti}-116^{c}$ & 17 & & 59.9 & & Smooth, no attack. & \\
\hline $\mathrm{Ti}-118^{c}$ & 12 & & 59.9 & & Smooth, no attack & \\
\hline \multicolumn{7}{|c|}{ Loop L-4-13 } \\
\hline \multicolumn{7}{|c|}{ Core-channel coupons } \\
\hline \multicolumn{7}{|c|}{ Type $347 \mathrm{SS}$} \\
\hline $1022 \mathrm{~A}$ & 13 & 4.4 & $61.6-62.6$ & -6.8 & Pits (up to 3 mils) on all surfaces & 61 \\
\hline $1027 A$ & 13 & 1.3 & $61.6-61.3$ & -1.2 & A few 1-mil pits on all surfaces & \\
\hline \multicolumn{7}{|c|}{ Type $309 \mathrm{SCb}$ SS } \\
\hline$C-53$ & 37 & 2.4 & $58.6-60.7$ & -1.3 & One-mil pits spread uniformly over surface & \\
\hline$C-57$ & 12 & 1.3 & $59.6-60.0$ & -1.8 & Smooth, no attack & \\
\hline \multicolumn{7}{|c|}{ Crystal-bar zirconium } \\
\hline$Z-101$ & 11 & 5.3 & $59.4-60.0$ & -7.4 & Surface slightly roughened; no pits or cracks & \\
\hline Z-104 & 44 & 2.0 & $59.1-59.9$ & -4.8 & Surface slightly roughened; no pits or cracks & \\
\hline \multicolumn{7}{|c|}{ In-line-channel coupons } \\
\hline \multicolumn{7}{|c|}{ Type 347 SS } \\
\hline $1031 \mathrm{~A}$ & 13 & & $58.3-61.2$ & -0.6 & Smooth, no pits & \\
\hline $1037 \mathrm{~A}$ & 13 & & $59.6-60.7$ & -0.8 & Smooth, no pits & \\
\hline
\end{tabular}


Table 30 (continued)

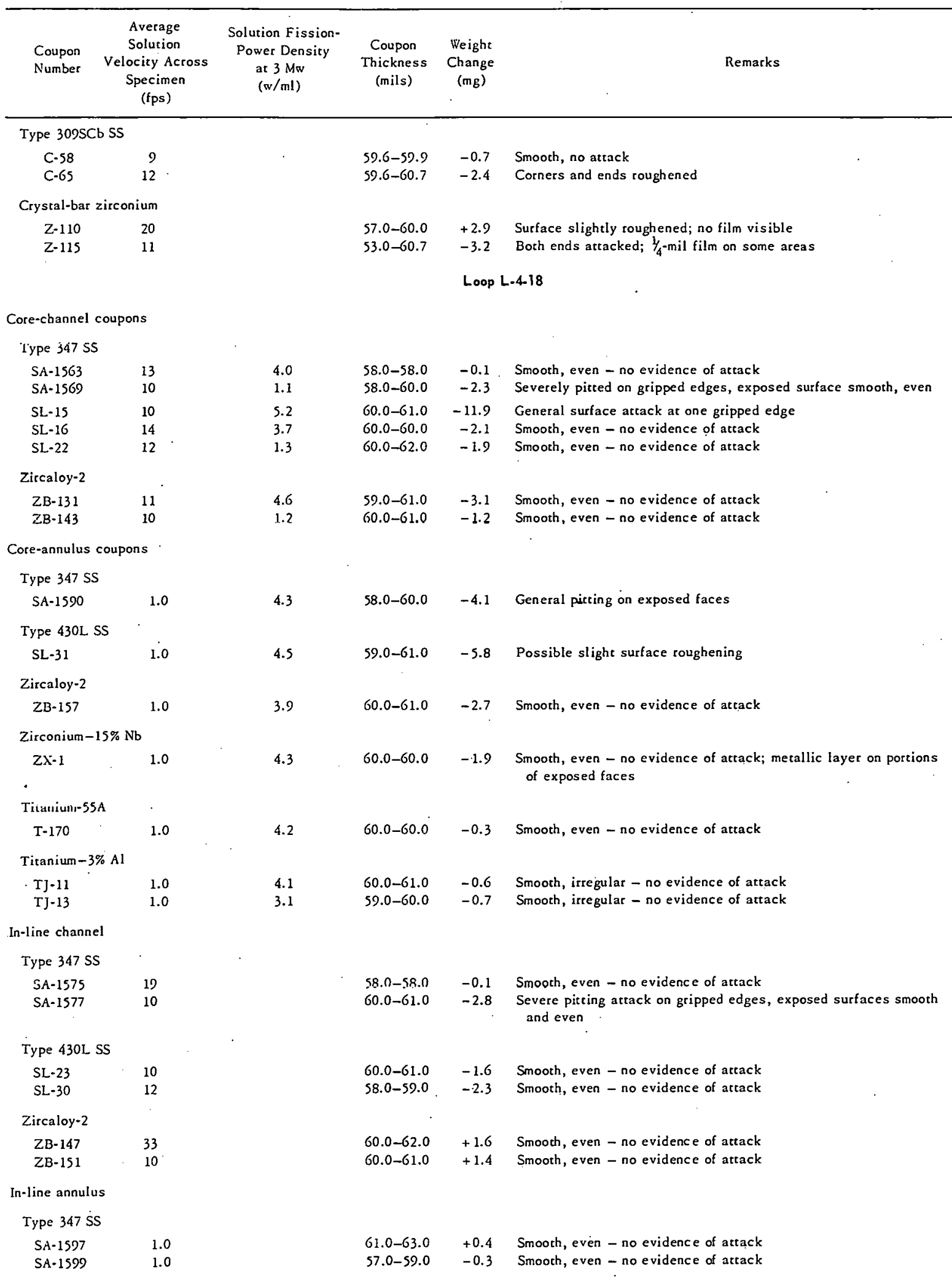


Table 30 (continued)

\begin{tabular}{|c|c|c|c|c|c|c|}
\hline $\begin{array}{l}\text { Coupon } \\
\text { Number }\end{array}$ & $\begin{array}{c}\text { Average } \\
\text { Solution } \\
\text { Velocity Across } \\
\text { Specimen } \\
\text { (fps) }\end{array}$ & $\begin{array}{l}\text { Solution Fission- } \\
\text { Power Density } \\
\text { at } 3 \mathrm{Mw} \\
(\mathrm{w} / \mathrm{ml})\end{array}$ & $\begin{array}{l}\text { Coupon } \\
\text { Thickness } \\
\text { (mils) }\end{array}$ & $\begin{array}{c}\text { Weight } \\
\text { Change } \\
\text { (mg) }\end{array}$ & Remarks & $\begin{array}{l}\text { Figure } \\
\text { Number }\end{array}$ \\
\hline \multicolumn{7}{|c|}{ Type 430L SS } \\
\hline $\begin{array}{l}S L-32 \\
S L-45\end{array}$ & $\begin{array}{l}1.0 \\
1.0\end{array}$ & & $\begin{array}{l}60.0-61.0 \\
60.0-61.0\end{array}$ & $\begin{array}{l}-2.1 \\
-4.6\end{array}$ & $\begin{array}{l}\text { Smooth, even - no evidence of attack } \\
\text { General surface attack, one face }\end{array}$ & \\
\hline \multicolumn{7}{|l|}{ Zircaloy-2 } \\
\hline ZB-161 & 1.0 & & $60.0-61.0$ & +1.7 & Smooth, even - no evidence of attack & \\
\hline \multicolumn{7}{|c|}{ Zirconium-15\% Nb } \\
\hline $2 x-5$ & 1.0 & & $60.0-60.0$ & +0.7 & Smooth, even - no evidence of attack & \\
\hline \multicolumn{7}{|c|}{ Titanium-55A } \\
\hline$T=173$ & 1.0 & & $58.0-60.0$ & +0.2 & Smooth, even - no evidence of attack & \\
\hline \multicolumn{7}{|c|}{ Titanium-3\% Al } \\
\hline TJ-15 & 1.0 & & $61.0-61.0$ & +0.1 & Smooth, irregular - no evidence of atcack & $:$ \\
\hline
\end{tabular}

${ }^{a}$ Based on as-removed weight change.

${ }^{b}$ Adjacent to loose coupons.

${ }^{c}$ Coupons damaged - Loose in holder.

exposure, since some of the stock end caps from which this core cap was drawn have the same blistered appearance. The surfaces of the cap and core walls are shown in Figs. 32 and 33.

The Zircaloy-2 impact specimens and Zircaloy-2 sample holder also exhibited differences in appearance, depending upon their location in the core. The Zircaloy-2 surfaces in the low-flux areas were covered with a heavy black film, which gradually changed to a brown color and became thinner at the higher fluxes. The surfaces in the highest flux regions appeared to be completely free of film. The original fine machine marks were visible at the high-flux end of the Zircaloy-2 holder. The stainless steel specimens in the core were also covered with film which varied in appearance as did that on the core walls. No evidence was apparent of a velocity effect on the character of film on the specimens.

Both the in-line specimens and the core specimens were defilmed, inspected visually, and weighed. Figure 34 is a group photograph of the defilmed core and in-line coupons. Figures 35-41 are magnified photographs of the individual coupons. Only two typical in-line coupons are included, while all the coupons from the core assembly are shown. In both cases the flow pattem is from position $A$ through position $L$, with the high-velocity region, approximately $50 \mathrm{fps}$, on the trailing edge of position $G$ and the leading edge of position $H$. The sides of core coupons $\mathrm{B}$ through $\mathrm{D}$, which were encased and apparently protected by the holder, stand in relief above the exposed surfaces. For coupon $A$, approximately $60 \%$ of the encased area was attacked to the same degree as the exposed areas. This additional attacked area has been treated as exposed area in consideration of the weight data. The calculations are listed in Table 36.

Corrosion of the core coupons appeared to start with shallow pits which apparently grew laterally until, in the case of the coupons in the highest flux, the entire surface was removed.

A further comment involves the defilming characteristics of the coupons. Since all coupons were defilmed cathodically in an inhibited sulfuric acid solution, the ease with which these films were removed 
Table 31. Summory of Metallographic Examination of Stress Corrosion Specimens

\begin{tabular}{|c|c|c|c|c|}
\hline Specimen Number & $\begin{array}{c}\text { Solution }^{a} \\
\text { Fission-Power } \\
\text { Density at } \\
3-\mathrm{Mw} \\
(\mathrm{w} / \mathrm{ml})\end{array}$ & $\begin{array}{c}\text { Weight } \\
\text { Change } \\
\text { (mg) }\end{array}$ & $\begin{array}{l}\text { Coupled } \\
\text { to }\end{array}$ & Remarks \\
\hline \multicolumn{5}{|c|}{ Loop EE } \\
\hline \multicolumn{5}{|l|}{$\begin{array}{l}\text { Core-annulus specimens } \\
\text { Type } 347 \text { SS }\end{array}$} \\
\hline SS-11 & 2.7 & -33.7 & SS-12 & Slight pitting attack - less than 1 mil deep \\
\hline SS-12 & 2.7 & -35.5 & SS-11 & Slight pitting attack - less than 1 mil deep \\
\hline SS: 13 & 2.7 & -26.1 & SS-14 & Slight pitting attack - less than 1 mil deep \\
\hline SS-14 & 2.7 & -30.6 & SS-13 & Slight pitting attack - less than 1 mil deep \\
\hline \multicolumn{5}{|l|}{ Zircaloy-2 } \\
\hline $\mathrm{Zr}-2$ & 2.7 & -93.1 & $Z_{r-3}$ & Very rough, uneven surface \\
\hline $\mathrm{Zr}-3$ & 2.7 & -94.0 & $\mathrm{Zr}-2$ & Very rough, uneven surface \\
\hline $\mathrm{Zr}_{\mathrm{r}}-4$ & 2.7 & -76.4 & $Z_{r}-5$ & Very rough, uneven surface \\
\hline $\mathrm{Zr}-5$ & 2.7 & -72.4 & $\mathrm{Zr}-4$ & Very rough, uneven surface \\
\hline \multicolumn{5}{|l|}{ Titanium-55A } \\
\hline Ti-1 & 2.7 & -3.2 & $\mathrm{Ti}-2$ & No evidence of corrosive attack \\
\hline $\mathrm{Ti}-2$ & 2.7 & -3.1 & $\mathrm{~T}_{\mathrm{i}-1}$ & No evidence of corrosive attack … \\
\hline Ti-11 & 2.7 & -4.5 & Ti-12 & No evidence of corrosive attack \\
\hline $\mathrm{Ti}-12$ & 2.7 & -3.8 & $\mathrm{Ti}-11$ & No evidence of corrosive attack \\
\hline \multicolumn{5}{|c|}{ Loop L-4-12 } \\
\hline Core-annulus specimens & & & & $\cdot$ \\
\hline Titanium-6A1-4V & & & & . \\
\hline TJ-11 & 2.4 & -29.1 & $\mathrm{~T} \mathrm{~J}-12$ & $\begin{array}{l}\text { Small cracks in tension surface near end; } \\
\text { otherwise smooth }\end{array}$ \\
\hline $\mathrm{TJ}-12$ & 2.4 & -26.1 & $\mathrm{TJ}=11$ & $\begin{array}{l}\text { One-mil cracks at extreme end of tension } \\
\text { surface; otherwise slightly roughened }\end{array}$ \\
\hline $\mathrm{TJ}-13$ & 2.4 & -29.4 & $\mathrm{TJ}-14$ & $\begin{array}{l}\text { Tension surface rough; compression sur- } \\
\text { face smooth; no cracking }\end{array}$ \\
\hline $\mathrm{TJ}-14$ & 2.4 & -25.2 & $\mathrm{TJ}-13$ & $\begin{array}{l}\text { One-half-mil cracks in the end of tension } \\
\text { surface and on center of compression } \\
\text { surface; otherwise smooth }\end{array}$ \\
\hline $\begin{array}{l}\text { In-line-annulus specimens } \\
\text { Titanium- } 6 \mathrm{~A} 1-4 \mathrm{~V}\end{array}$ & & & - & \\
\hline $\mathrm{TJ}-7$ & & -5.5 & $T J-8$ & $\begin{array}{l}\text { Both surfaces smooth; attack not apparent } \\
\text { from metallographic examination }\end{array}$ \\
\hline $\mathrm{TJ}-8$ & & -6.3 & $\mathrm{TJ}-7$ & $\begin{array}{l}\text { Tension surfacc smooth; compression } \\
\text { surface slightly roughened; no cracks }\end{array}$ \\
\hline TJ -9 & & -4.9 & $\mathrm{TJ}-10$ & $\begin{array}{l}\text { One-half-mil cracks in tension surface at } \\
\text { one end; other surfaces slightly } \\
\text { roughened }\end{array}$ \\
\hline $\mathrm{TJ}-10$ & & -2.9 & $T J-9$ & $\begin{array}{l}\text { Both surfaces slightly roughened; no } \\
\text { cracking }\end{array}$ \\
\hline $\begin{array}{l}\text { Pressurizer (liquid phase) } \\
\text { Type 17-4 PH SS }\end{array}$ & & & & \\
\hline $\mathrm{SH}-1$ & & -49.1 & TE-1 & $\begin{array}{l}\text { Tension surface slightly roughened; com- } \\
\text { pression surface smooth; small cracks } \\
\text { in both surfaces }\end{array}$ \\
\hline $\mathrm{SH}-3$ & & -1.4 & $\mathrm{TJ}-1$ & Both surfaces smooth \\
\hline
\end{tabular}


Table 31 (continued)

\begin{tabular}{|c|c|c|c|c|}
\hline Specimen Number & $\begin{array}{c}\text { Solution }^{a} \\
\text { Fission-Power } \\
\text { Density at } \\
3-\mathrm{Mw} \\
(\mathrm{w} / \mathrm{ml})\end{array}$ & $\begin{array}{l}\text { Weight } \\
\text { Change } \\
\text { (mg) }\end{array}$ & $\begin{array}{l}\text { Coupled } \\
\text { to }\end{array}$ & Remarks \\
\hline \multicolumn{5}{|l|}{ Titanium C-130AM } \\
\hline TE-1 & & -27.2 & $\mathrm{SH}-1$ & $\begin{array}{l}\text { Both surfaces rough; compression } 2 \text { or } 3 \\
\text { times as bad as tension }\end{array}$ \\
\hline$T E-5$ & & -1.0 & TE-6 & $\begin{array}{l}\text { Both surfaces smooth; attack not appar- } \\
\text { ent from metallographic examination }\end{array}$ \\
\hline TE-6 & & -2.9 & TE-S & $\begin{array}{l}\text { Both surfaces smooth; attack not appar- } \\
\text { ent from metallographic examination }\end{array}$ \\
\hline \multicolumn{5}{|l|}{ Titanium- $6 \mathrm{~A} 1-4 \mathrm{~V}$} \\
\hline $\mathrm{TJ}-1$ & & & $\mathrm{SH}-3$ & $\begin{array}{l}\text { Both surfaces slightly roughened; maxi- } \\
\text { mum variation } 1 / 2 \text { mil }\end{array}$ \\
\hline $\mathrm{TJ}-3$ & & +0.4 & $\mathrm{TJ}-4$ & $\begin{array}{l}\text { Both surfaces slightly roughened; no } \\
\text { cracking }\end{array}$ \\
\hline $\mathrm{TJ}-4$ & & -6.5 & $\mathrm{TJ}-3$ & $\begin{array}{l}\text { Tension surface slightly rooughened; no } \\
\text { cracking or pitting }\end{array}$ \\
\hline \multicolumn{5}{|l|}{ Pressurizer (vapor-phase) } \\
\hline \multicolumn{5}{|c|}{ Type $17-4 \mathrm{PH} \mathrm{SS}$} \\
\hline $\mathrm{SH}-2$ & & -35.7 & TE-2 & $\begin{array}{l}\text { Numerous pits on both surfaces, several } \\
\text { longitudinal interior cracks near one } \\
\text { end }\end{array}$ \\
\hline $\mathrm{SH}-4$ & & -9.1 & $T]-2$ & Both surfaces smooth \\
\hline \multicolumn{5}{|l|}{ Titanium $\mathrm{C}-130 \mathrm{AM}$} \\
\hline TE-2 & & -0.8 & SH-2 & $\begin{array}{l}\text { Both surfaces smooth; attack not appar- } \\
\text { ent from metallographic examination }\end{array}$ \\
\hline TE-3 & . & -0.8 & $\mathrm{TE}-4$ & $\begin{array}{l}\text { Both surfaces smooth; attack not appar- } \\
\text { ent from metallographic examination }\end{array}$ \\
\hline$T E-4$ & & -3.7 & $\mathrm{TE}-3$ & $\begin{array}{l}\text { Both surfaces smooth; attack not appar- } \\
\text { ent from metallographic examination }\end{array}$ \\
\hline \multicolumn{5}{|l|}{ Titanium- $6 \mathrm{~A} 1-4 \mathrm{~V}$} \\
\hline $\mathrm{TJ}-2$ & & & $\mathrm{SH}-4$ & $\begin{array}{l}\text { Both surfaces slightly roughened; no } \\
\text { cracking }\end{array}$ \\
\hline$T J-5$ & & -4.7 & TJ -6 & $\begin{array}{l}\text { Both surfaces smooth, attack not appar- } \\
\text { ent from metallographic examination }\end{array}$ \\
\hline TJ -6 & & -9.6 & $\mathrm{TJ}-5$ & $\begin{array}{l}\text { Several } \frac{1}{2} \text {-mil cracks scattered over } \\
\text { center } \frac{1}{3} \text { of tension surface, otherwise } \\
\text { smooth }\end{array}$ \\
\hline \multicolumn{5}{|c|}{ Loop L-4- 18} \\
\hline \multicolumn{5}{|l|}{ Core annulus } \\
\hline $\mathrm{ZB}-2$ & 2.6 & -25.4 & ZB-5 & Smooth, even - no attack \\
\hline ZB-5 & 2.6 & -24.8 & $\mathrm{ZB}-2$ & Smooth, even - no attack \\
\hline \multicolumn{2}{|l|}{ Zircaloy-2 } & & & \\
\hline $\mathrm{ZB}-6$ & & +6.2 & $\mathrm{ZB}-9$ & Smooth, even - no attack \\
\hline ZB-9 & & +6.4 & $\mathrm{ZB}-6$ & Smooth, even - no attack \\
\hline
\end{tabular}

${ }_{b}^{a}$ Average value for length of specimen

${ }^{b}$ Figure 60.

Note: Solution velocities across annulus specimens are $\sim 1.0 \mathrm{fps}$; solution velocities across pressurizer specimens are negligible. 


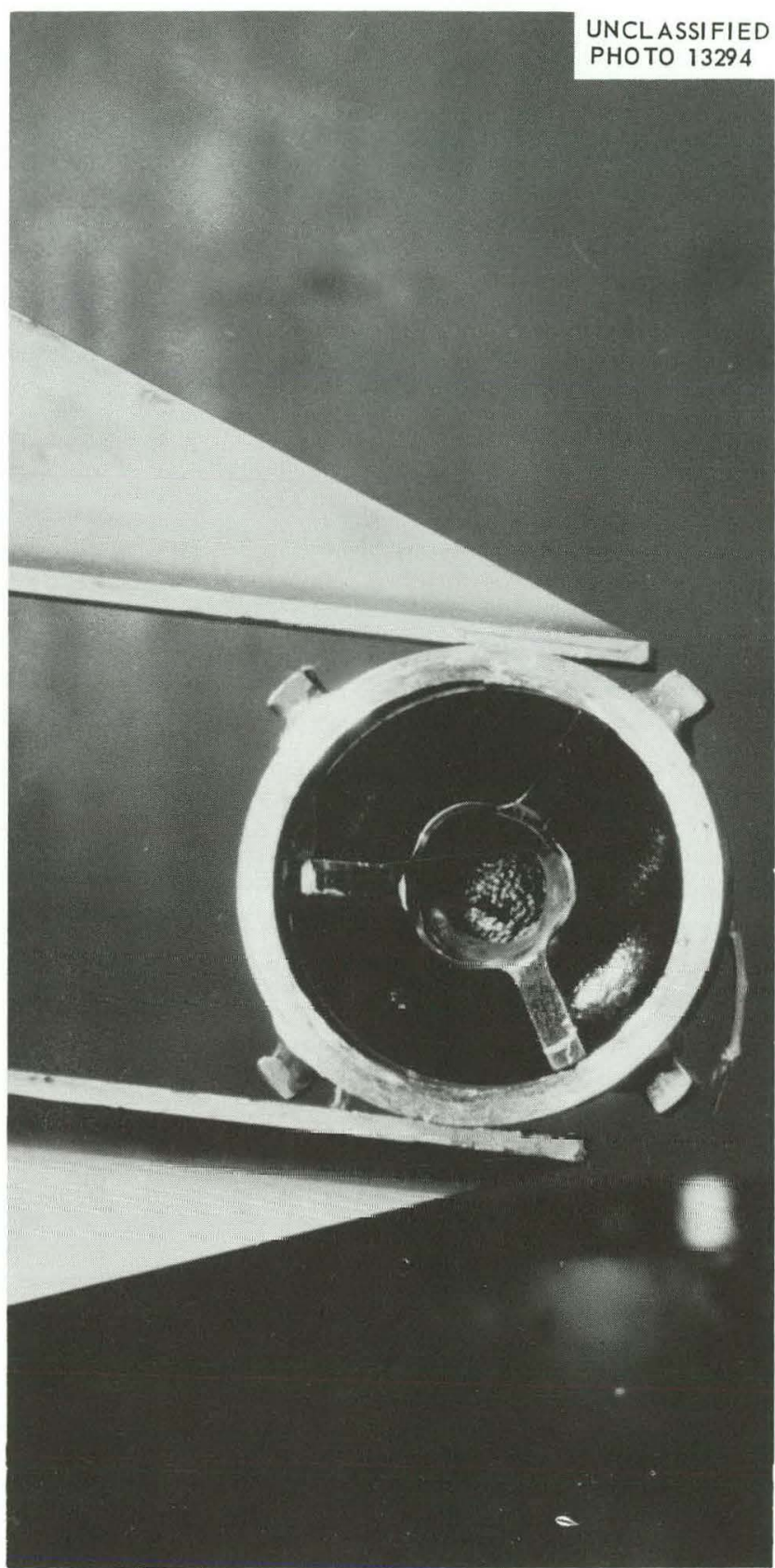

Fig. 32. Core Cap with Spider in Place, Loop DD.

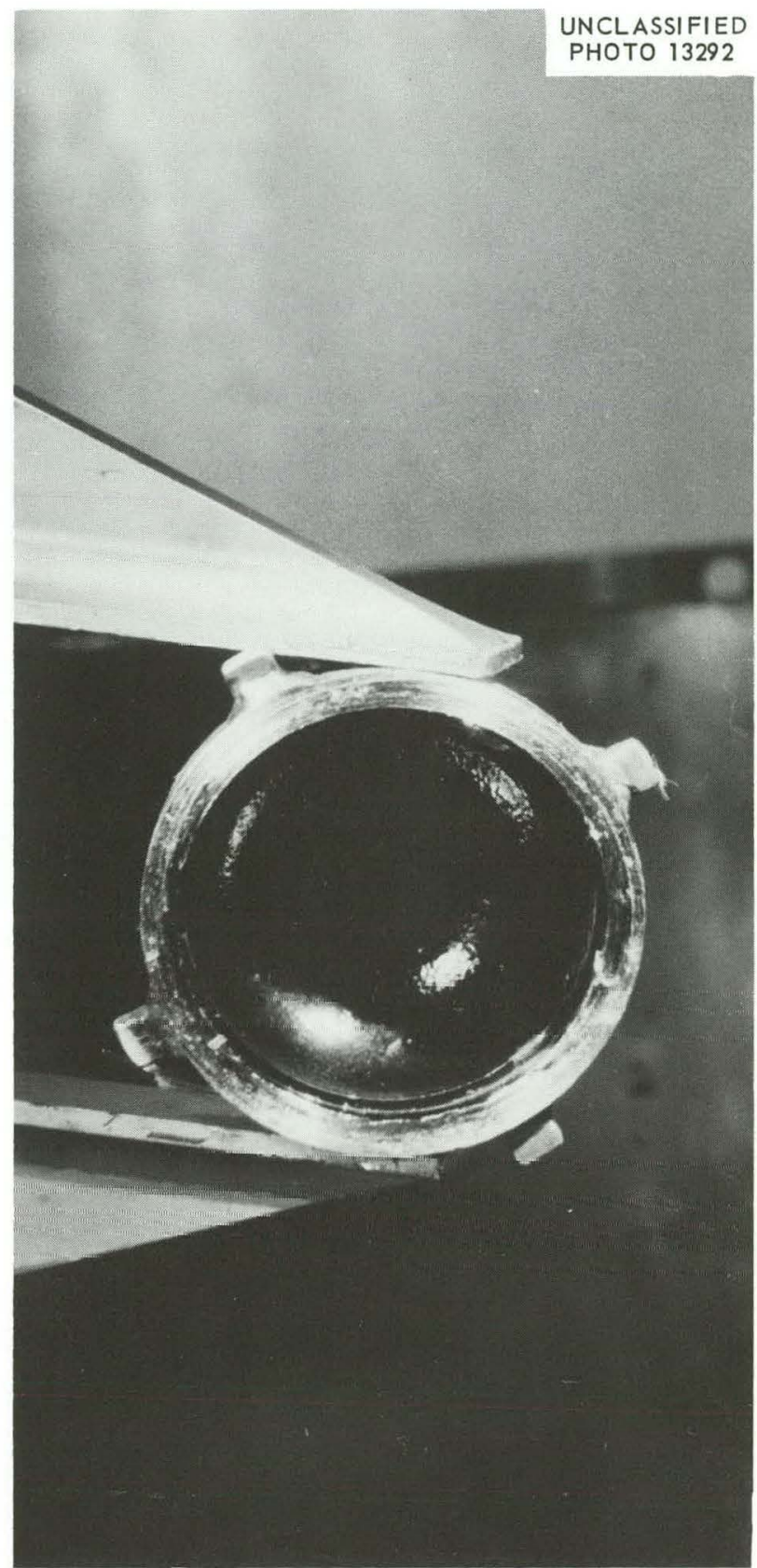

Fig. 33. Core Cap Alone, Loop DD. 
UNCLASSIFIED

PHOTO 13586

POSITION

POSITION

A

L

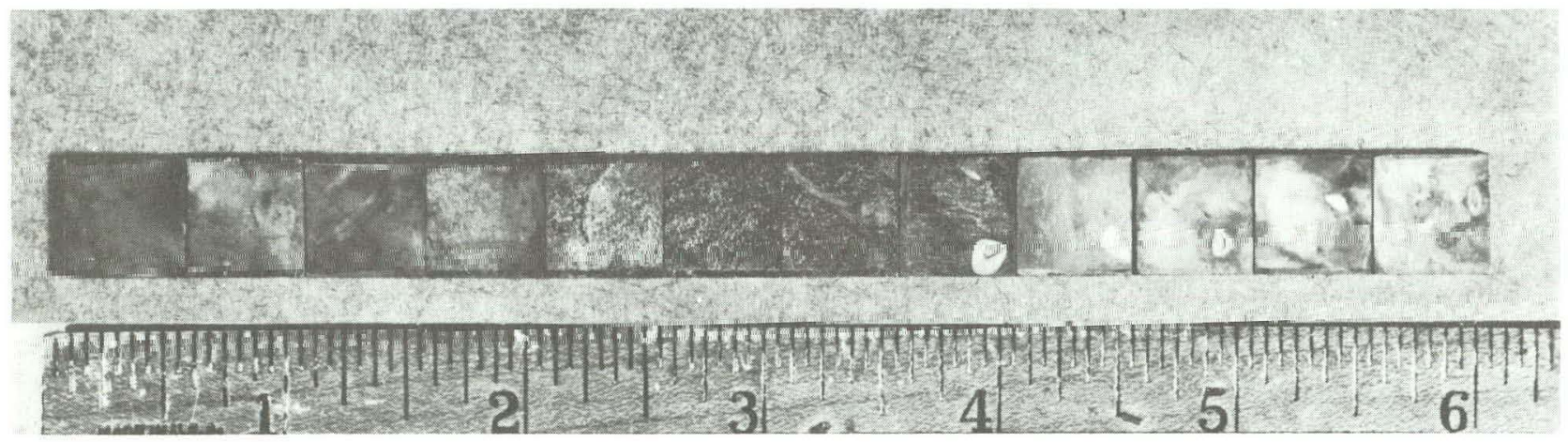

CORE ARRAY

POSITION

POSITION

A

L

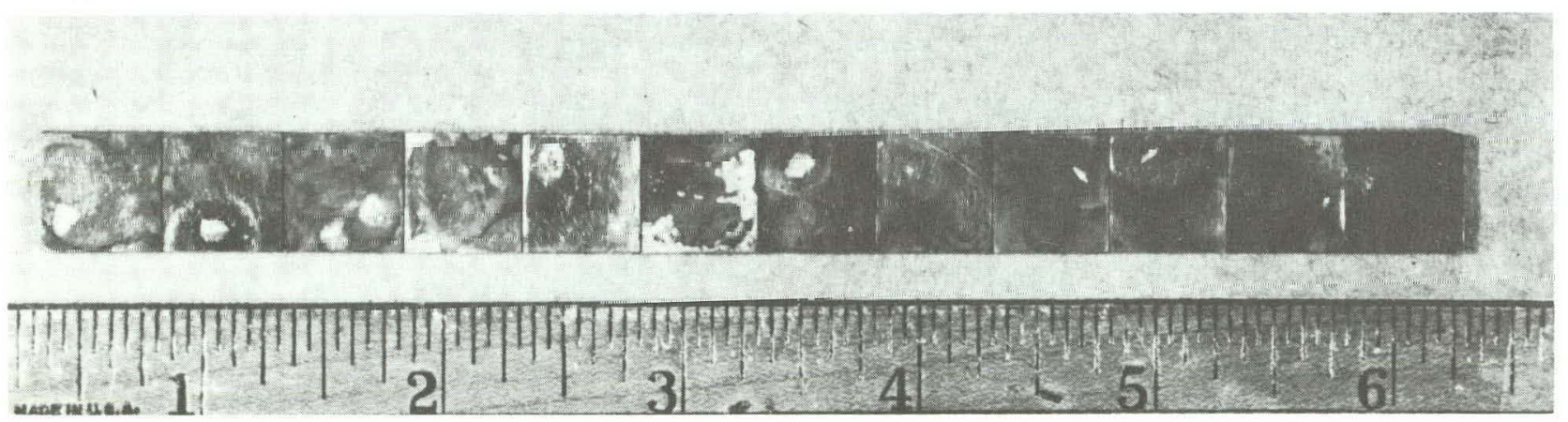

IN-LINE ARRAY

Fig. 34. HRP In-Pile Loop DD Corrosion Coupon Arrays After Defilming. $0.95 \mathrm{X}$. Reduced $2 \%$. 
UNCLASSI FIED

PHOTO 13580

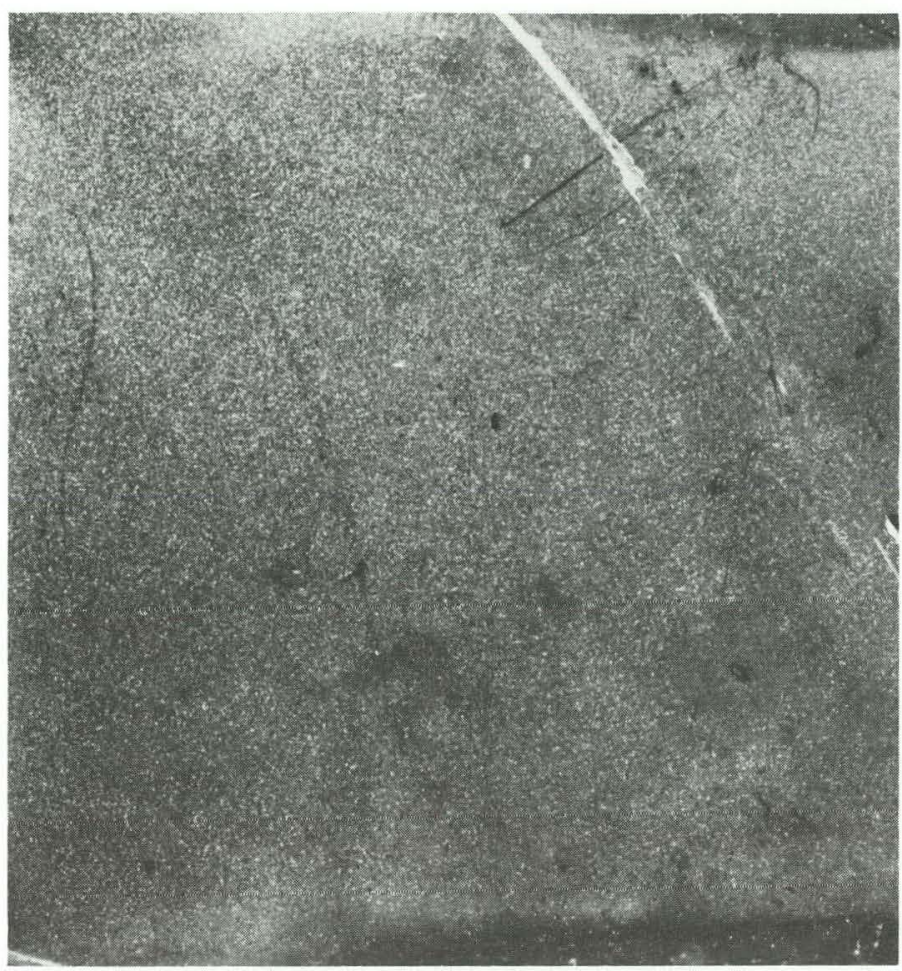

COUPON 436-A (POSITION A)

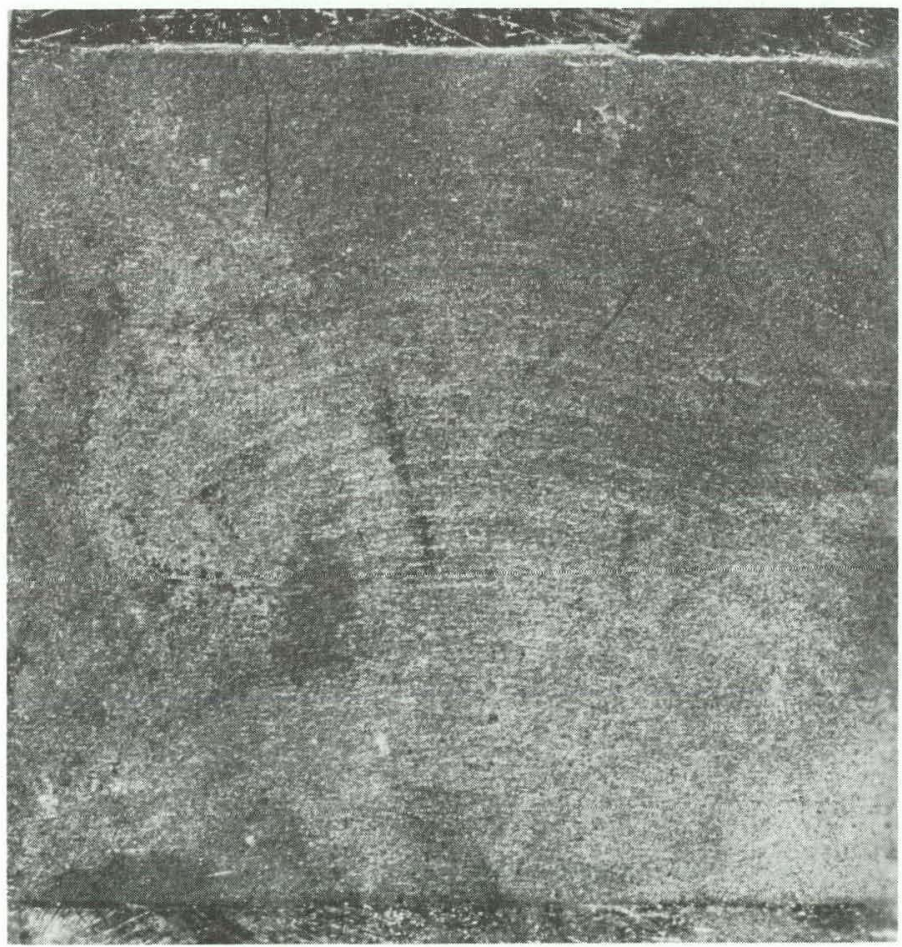

COUPON 437-A (POSITION B)
Fig. 35. Defilmed Type 347 Stainless Steel Corrosion Coupons from Core Holder of In-Pile Loop DD. 6.7 X. 
Fig. 36. Defilmed Type 347 Stainless Steel Corrosion Coupons from Core Holder of In.Pile Loop DD. 6.7 X.
UNCLASSI FIED

PHOTO 13582

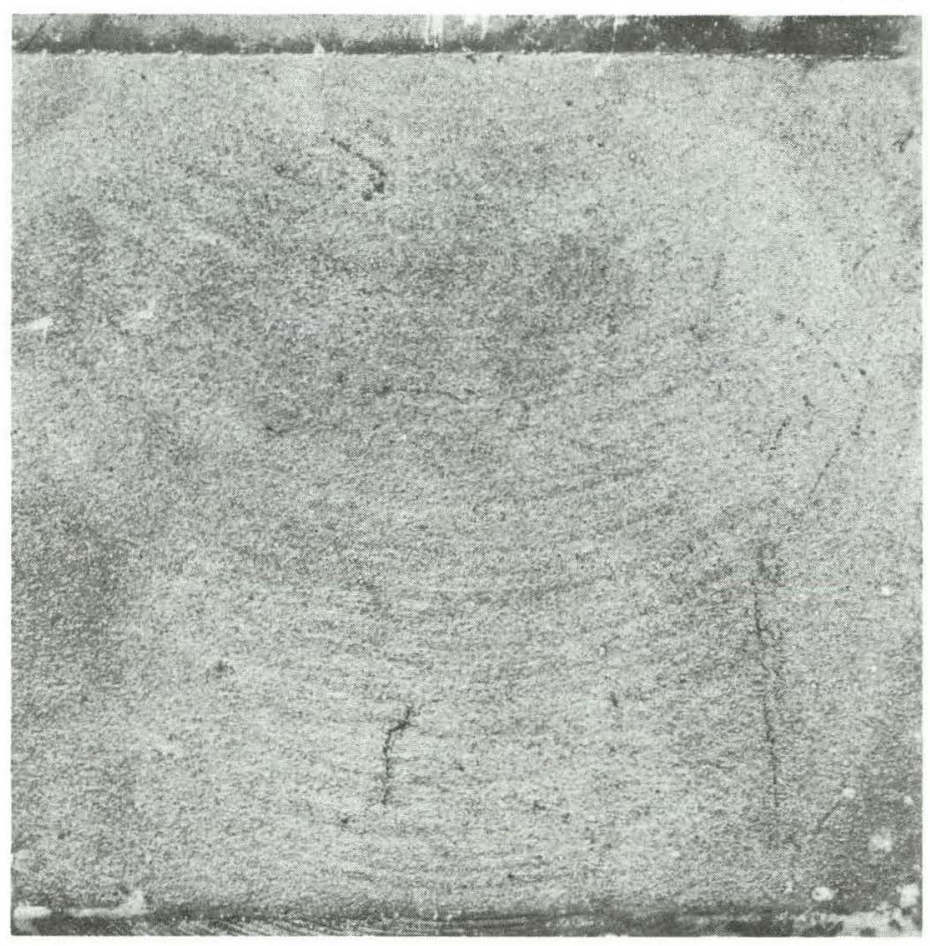

COUPON 438-A (POSITION C)

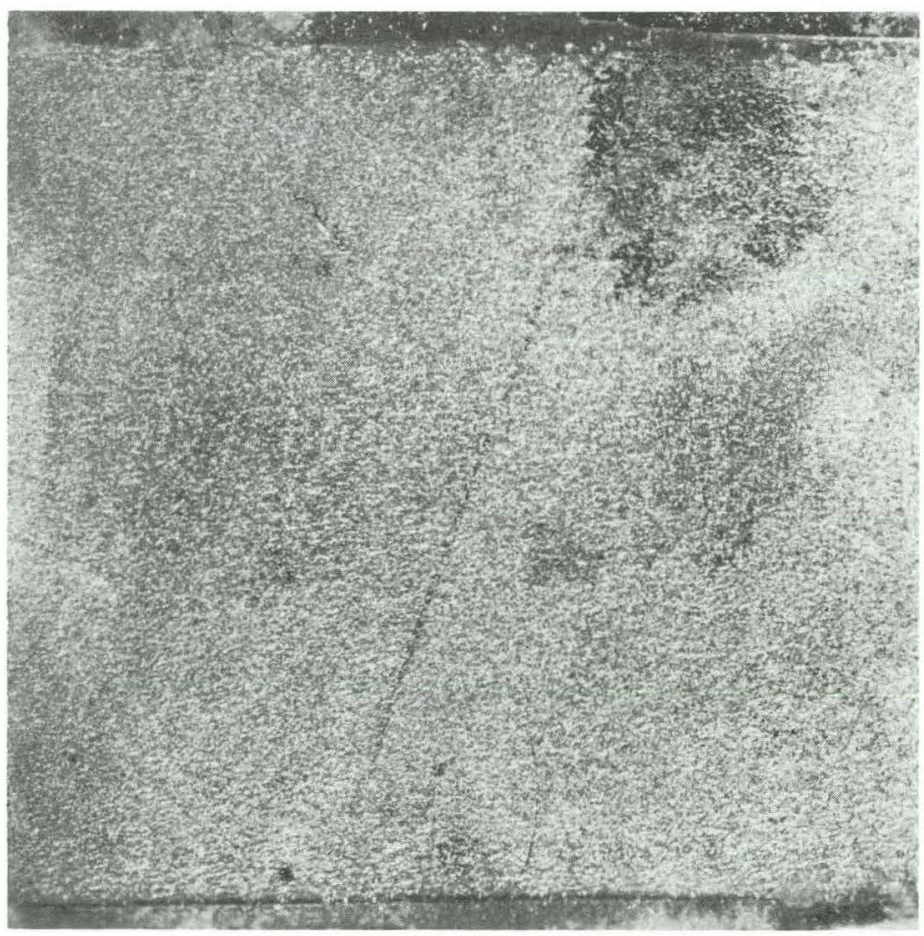

COUPON 439-A (POSITION D) 
UNCLASSIFIED

PHOTO 13584

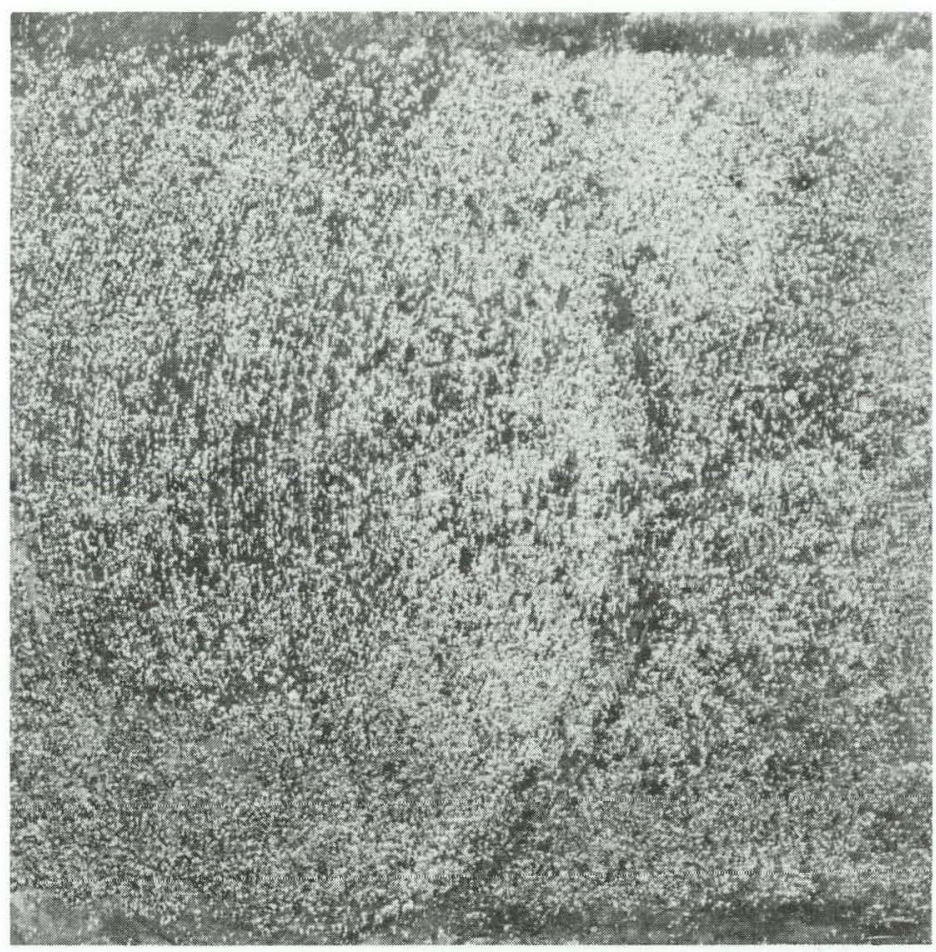

COUPON 440-A (POSITION E)

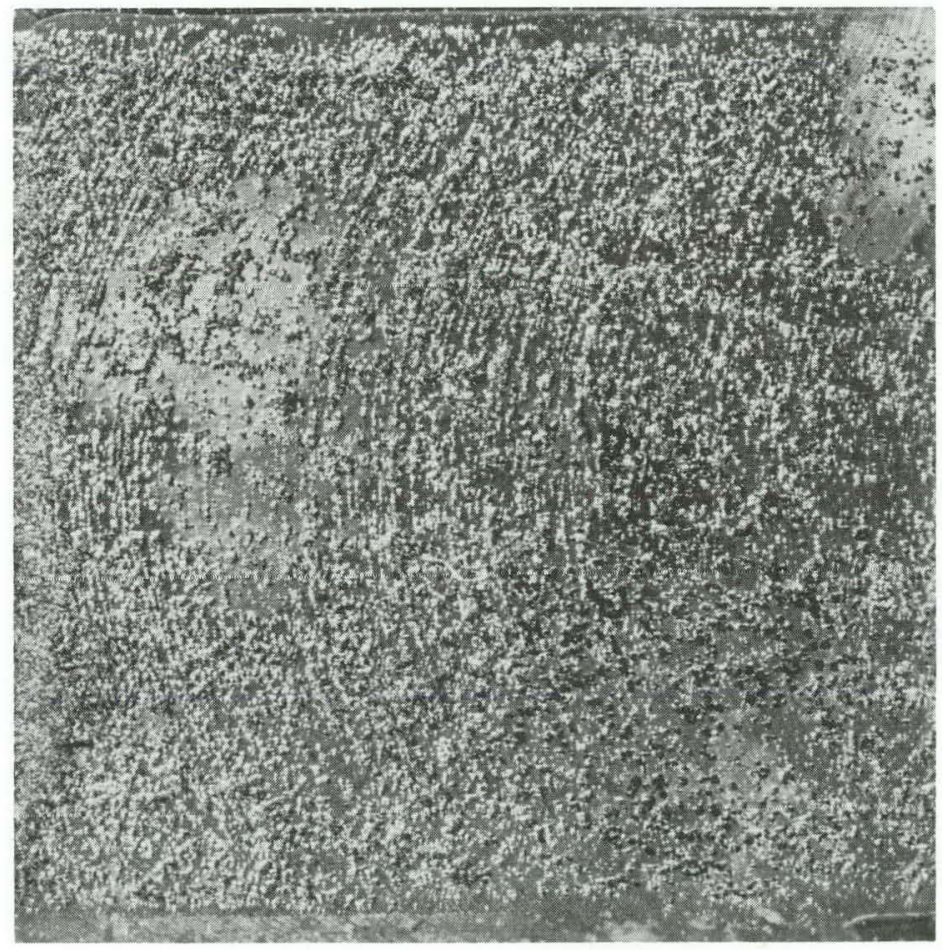

COUPON 441-A (POSITION F)
Fig. 37. Defilmed Type 347 Stainless Steel Corrosion Coupons from Core Holder of In-Pile Loop DD. 6.7 X. 
Fig. 38. Defilmed Type 347 Stainless Steel Corrosion Coupons from Core Holder of In-Pile Loop DD. 6.7 X.
UNCLASSIFIED

PHOTO 13583

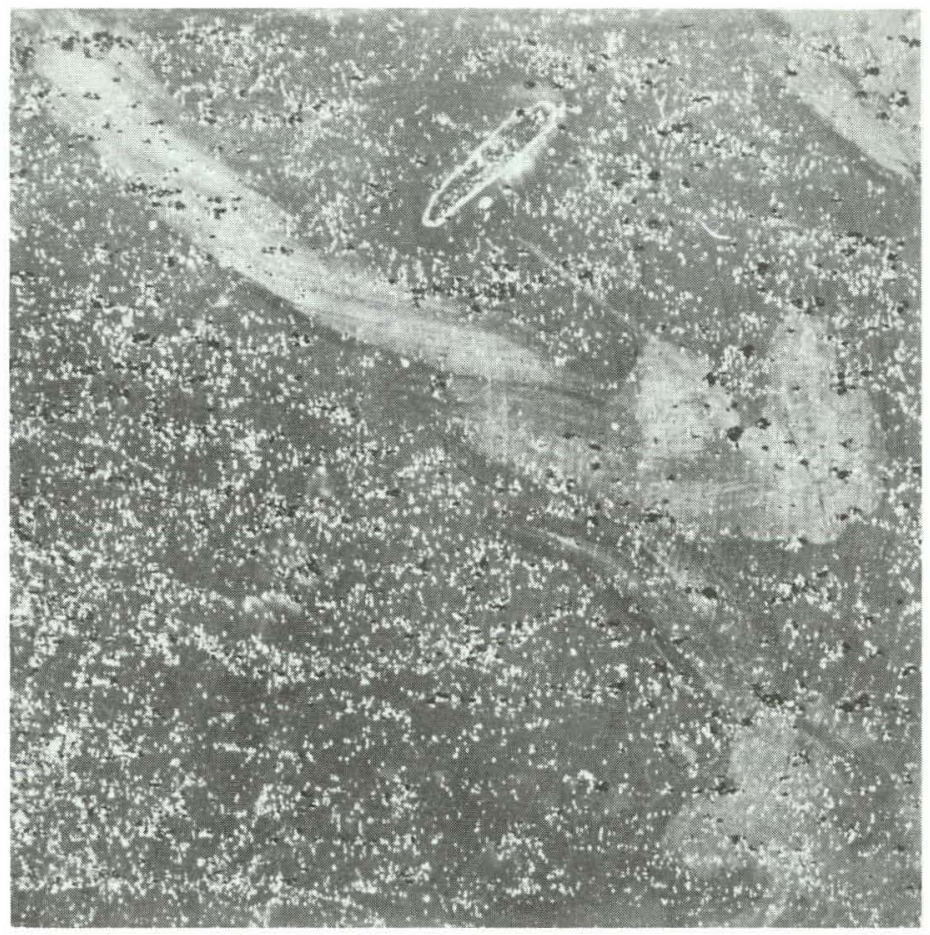

COUPON 442-A (POSITION G)

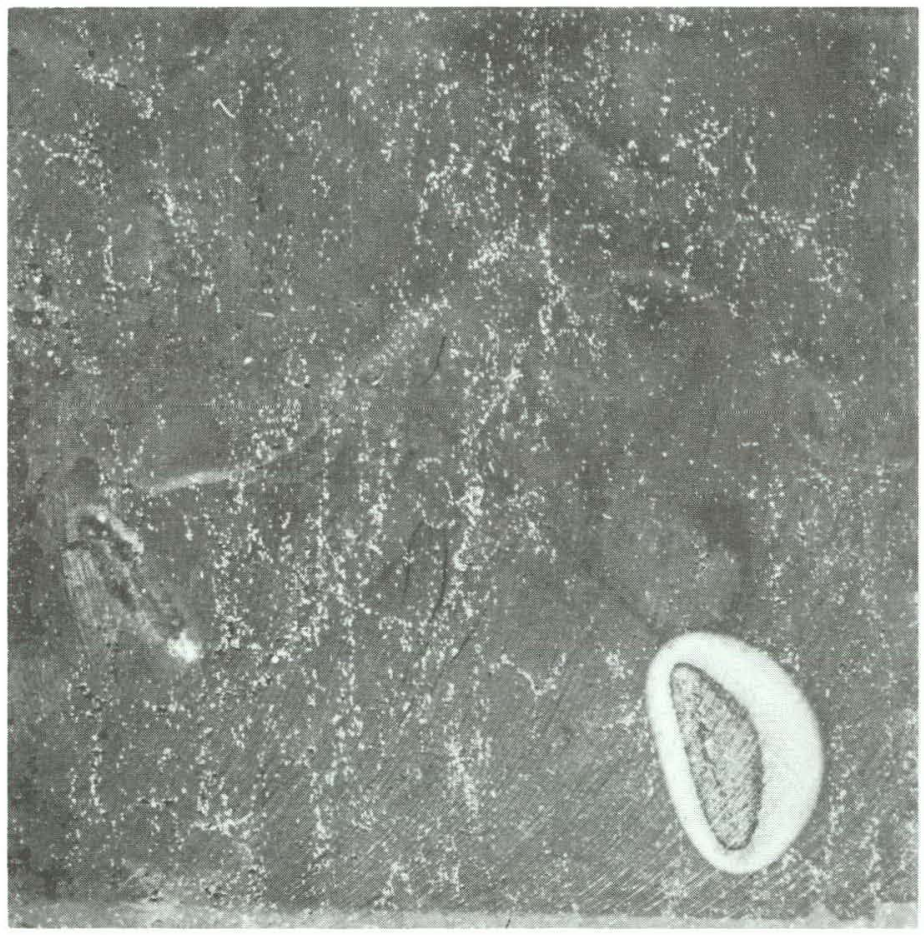

COUPON 443-A (POSITION H) 


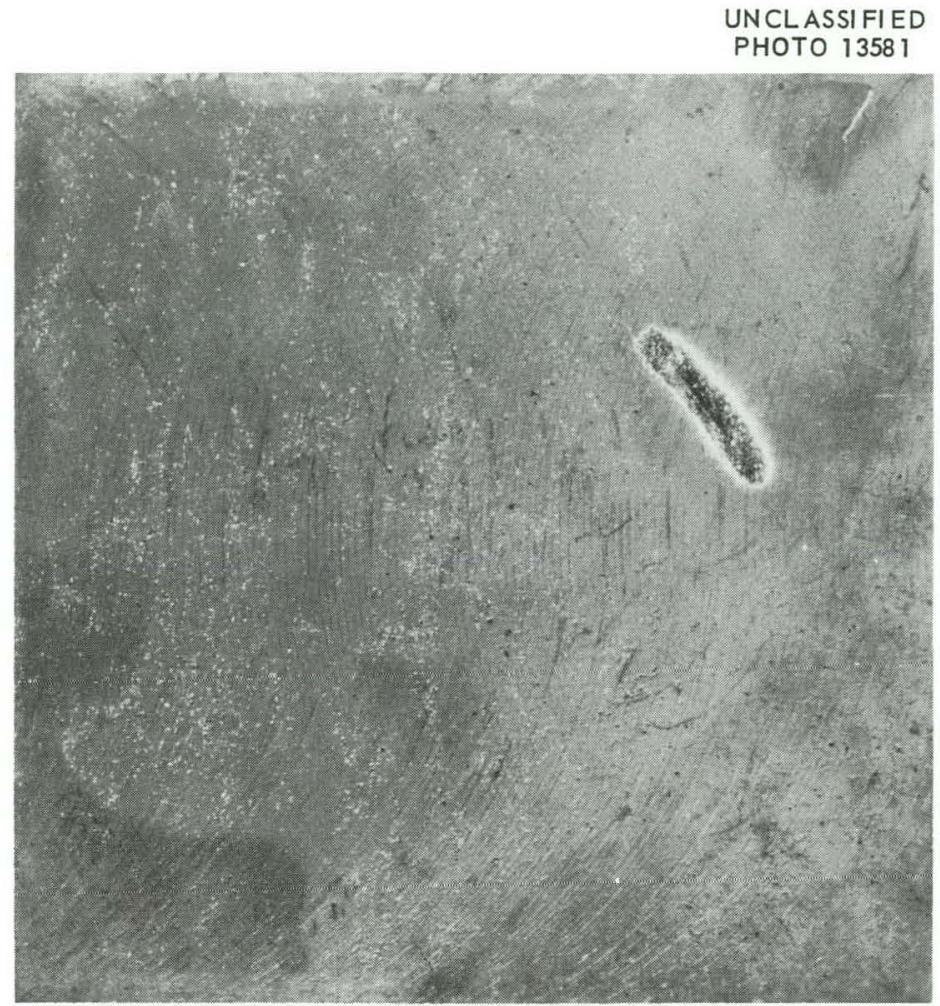

COUPON 444-A (POSITION I)

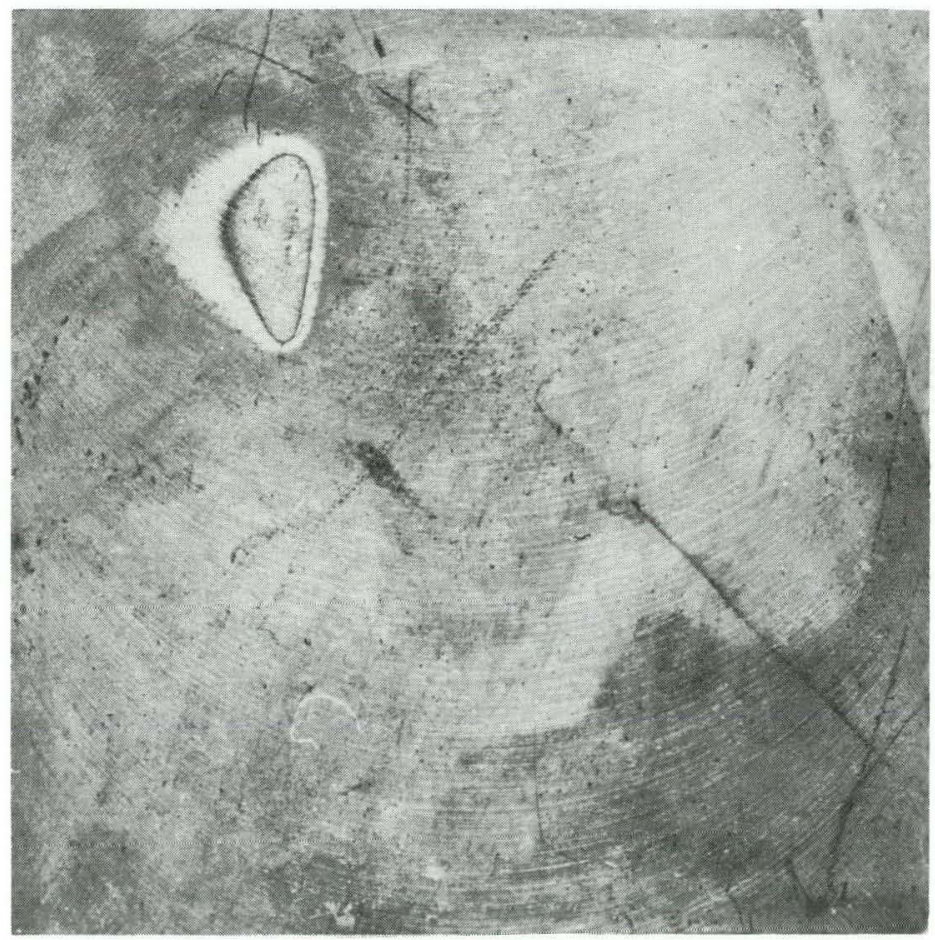

COUPON 445-A (POSITION J)
Fig. 39. Defilmed Type 347 Stainless Steel Corrosion Coupons from Core Holder of In-Pile Loop DD. 6.7 X. 
Fig. 40. Defilmed Type 347 Stainless Steel Corrosion Coupons from Core Holder of In-Pile Loop DD. 6.7 X.
UNCLASSIFIED

PHOTO 13587

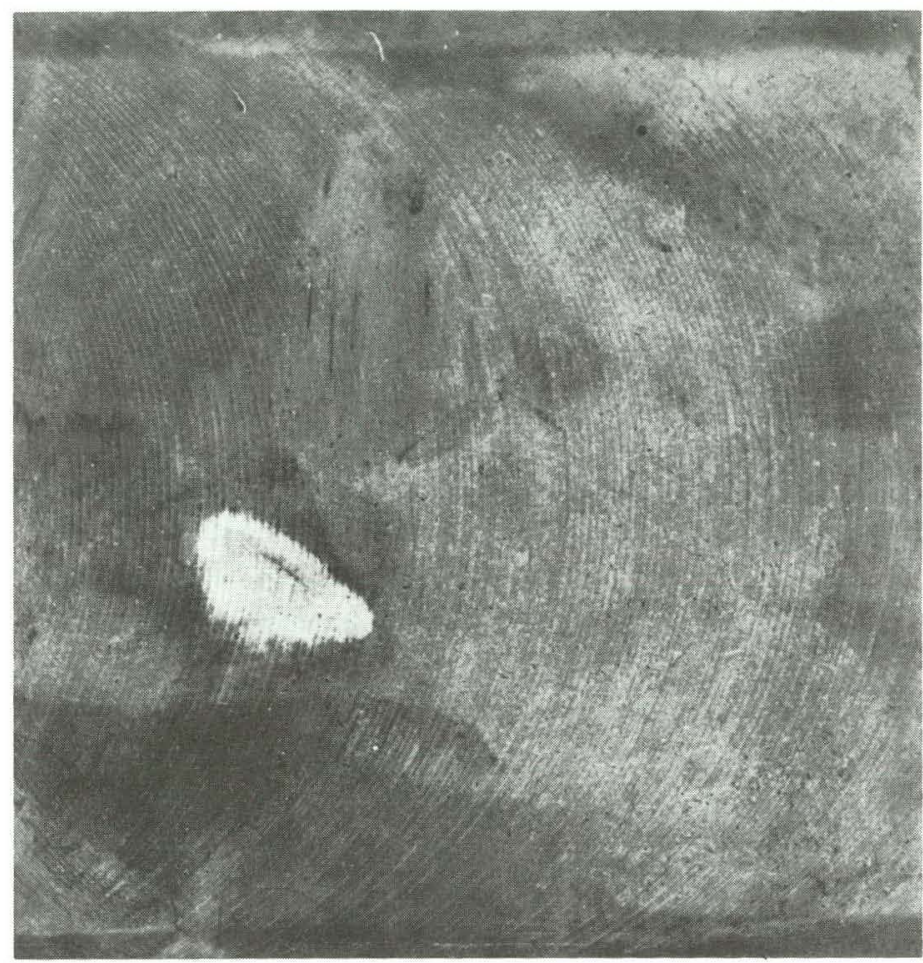

COUPON 446-A (POSITION K)

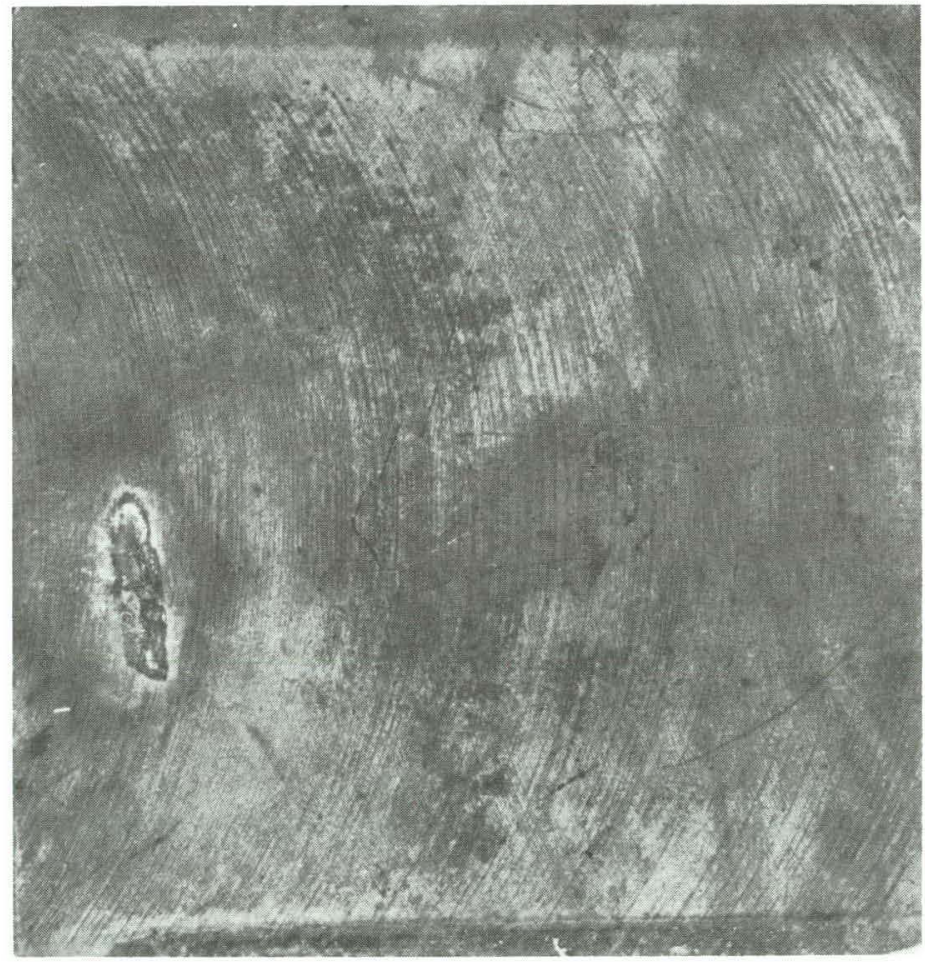

COUPON 447-A (POSITION L) 


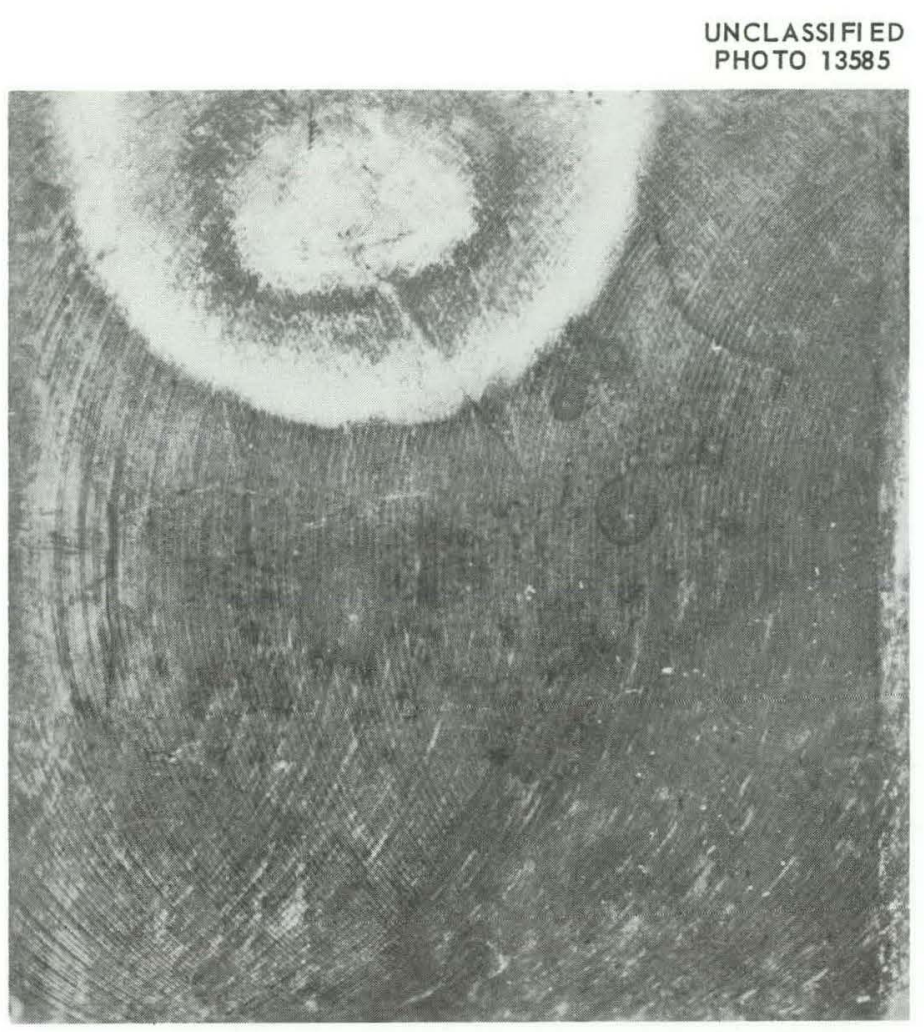

COUPON 449-A (POSITION A)

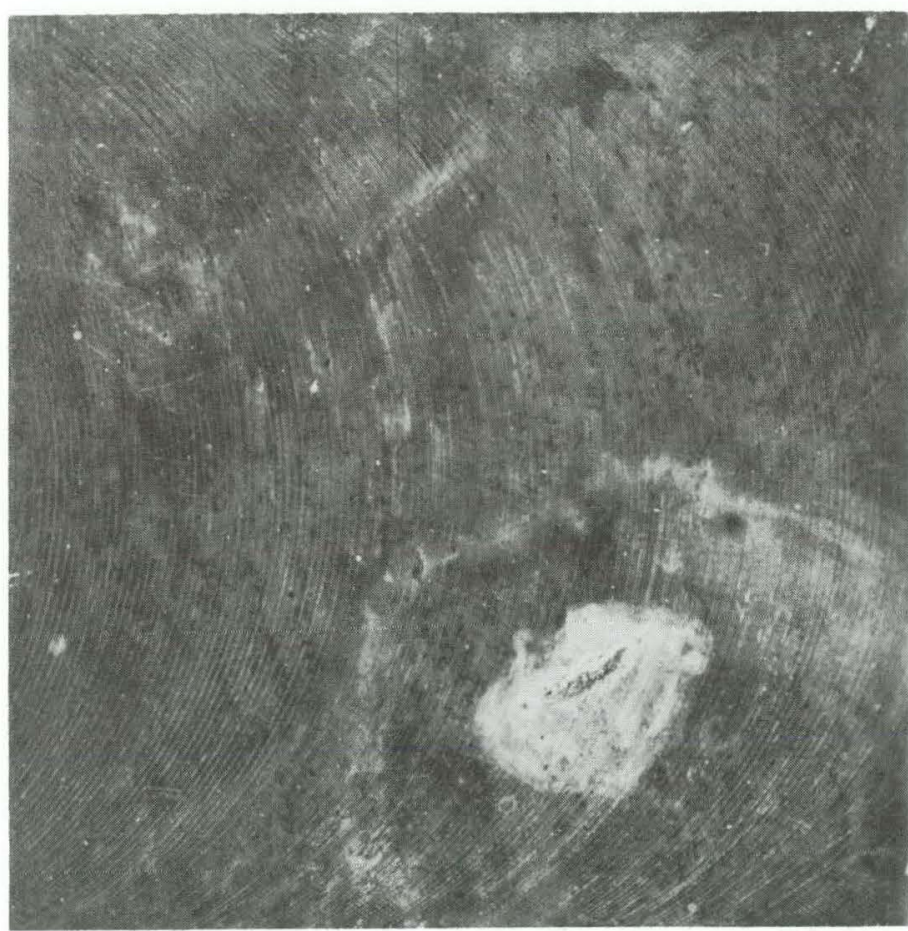

COUPON 454-A (POSITION G)
Fig. 41. Defilmed Type 347 Stainless Steel Corrosion Coupons from In-Line Holder, Loop DD. 6.7 X. 
is indicative of their protective nature. Every coupon from the core holder defilmed readily in 3 min at the normal current density of $20 \mathrm{amp} / \mathrm{dm}^{2}$; only the last five coupons exposed to the lowest fluxes showed any electrode effect. The electrode effect is the result of a momentary anodic reaction of the coupon caused by the voltage drop across the film. The result of this anodic reaction is a shiny area adjacent to the contact points. All the in-line coupons showed some electrode effect and each required from 10 to $15 \mathrm{~min}$ for defilming. Even after the application of voltage for this long period, the in-line specimens were not as completely defilmed as the core specimens.

\subsubsection{Loop FF}

All surfaces outside the core area were covered with a heavy rustlike scale, even in the high-velocity areas. Figure 42 is a picture of the coupons and interior surface of the in-line assembly; it shows that there was no apparent velocity effect upon the amount of deposited scale.

Figure 43 is a photograph of the core coupon and impact specimen assembly in the as-removed condition. All the stainless steel components in this region were covered with a rustlike scale. However, the deposit appeared to become thinner with increasing flux. The Zircaloy-2 holder and impact specimens were free from any scale deposit in the higher-flux regions. The only visible scale on the Zircaloy-2 holder was located around the spider at the low-flux end of the assembly. The machining marks and stamped identifications were clearly visible on both holder and coupons. There was no obvious indication of increased attack on the portions of specimens not protected by the holders, as was seen with the loop DD stainless steel core coupons.

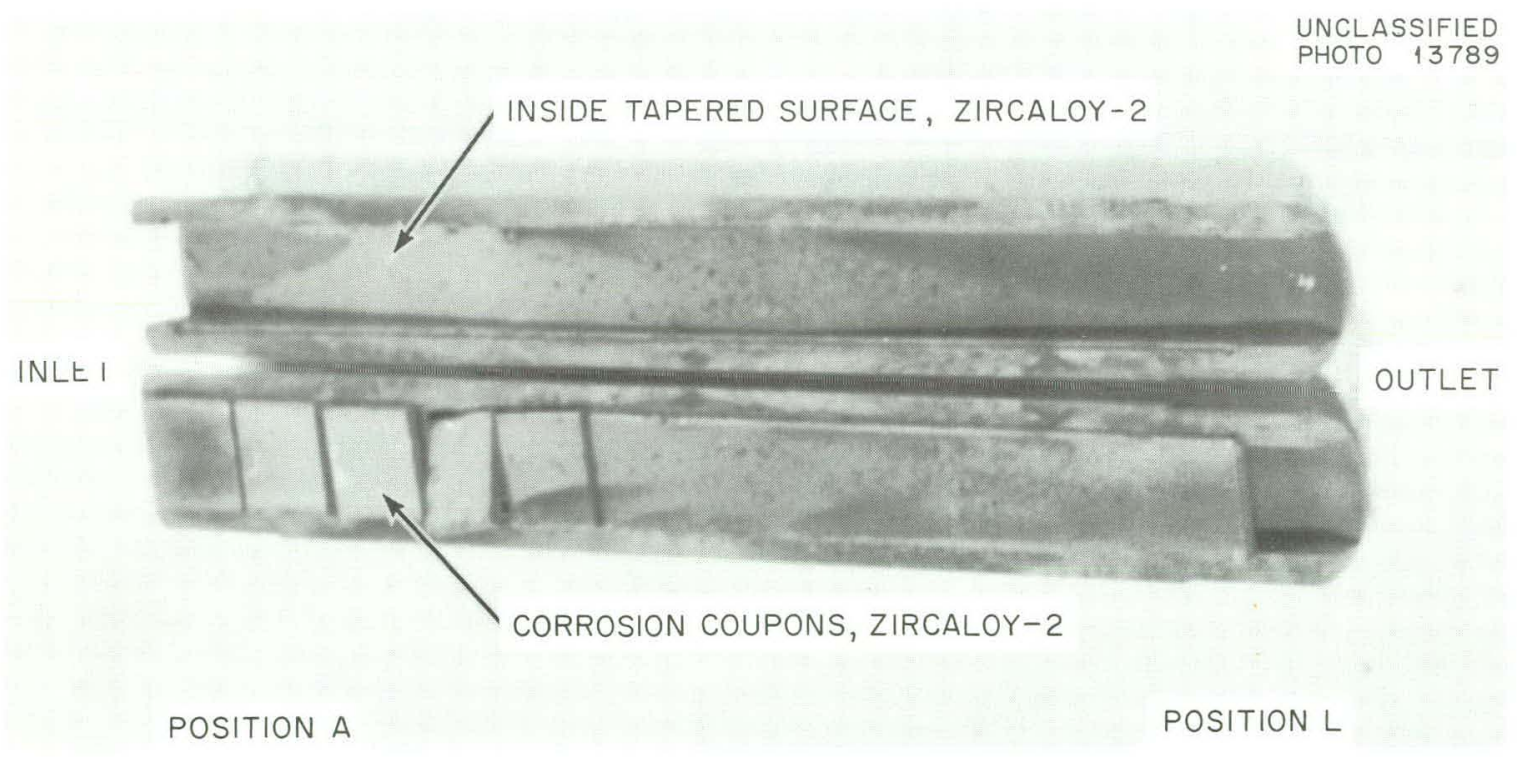

Fig. 42. In-Line Coupon Assembly Before Defilming, Loop FF. 


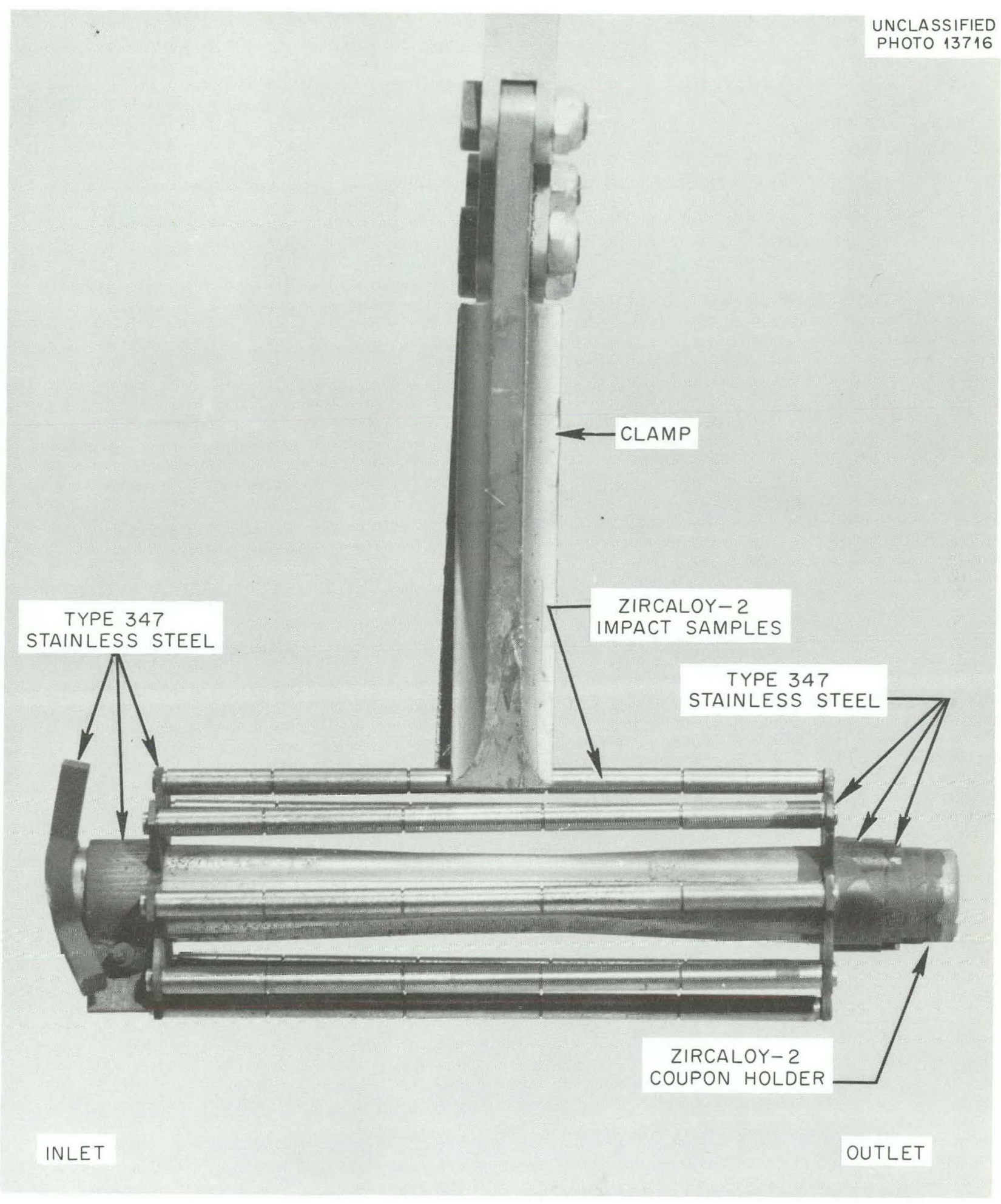

Fig. 43. Core Specimen Assembly, Loop FF. 
Corrosion coupons, coupon holders, and impact specimens were all removed from the loop and weighed in the as-removed condition. Although microscopic examination of the heavy scale on the in-line coupons showed that it had flaked off in some areas, prolonged cathodic treatment and mechanical brushing failed to remove this scale. Some of the scale was pulled from the metal surface by the use of Scotch tape, but this method was not completely effective either.

Examination of the stainless steel core body and cap surfaces indicated that the relative amounts of the covering oxide scale decreased with increasing flux. However, there was little change in oxide appearance with flux. In contrast, rather distinctive changes in scale character with flux were observed in the previous loop DD. Generally, there was no evidence of localized attack. However, during the preirradiation testing of the loop at $\mathrm{Y}-12$, a pinhole leak was detected in the reducer at the rear of the core assembly. This leak was repaired by grinding out the metal in that area and backfilling with weld metal. When the core was sectioned after irradiation, a rather large pit or cavity was found in the area of this repair. Figures 44 and 45 are general views of the core sections showing the extent of this cavity. A sample from this area was among the several samples submitted for metallographic examination.

\subsubsection{Loop GG}

As with the previous loops DD and FF, all surfaces outside the core area were covered with a heavy rustlike scale. There was no apparent localized attack on any component inspected. Figure 46 is a view of coupons from the in-line coupon holder and the interior tapered surface of the holder in the as-removed state. The loose, flaky nature of the bulk scale on the Zircaloy-2 coupons and holder is quite evident.

In the core region, all stainless steel surfaces appeared to be covered with a similar, but somewhat less bulky, rustlike scale. Figure 47 is a photograph of the core assembly in the as-removed condition. The stainless steel clamping bands on each end and the stainless steel "spiders" which held the impact samples were covered with a rustlike scale. As with loops DD and FF, the Zircaloy-2 impact specimens and holder surfaces appeared to be free from bulk-scale deposits in the higher flux region. Only on the extreme outlet, or low-flux, end of the core coupon holder was there any apparent buildup of scale. Closer examination under the remote microscope revealed that there was some film on all Zircaloy-2 surfaces. The thickness of the film was apparently inversely proportional to the flux at which the surface was exposed.

The core specimens were defilmed completely by cathodic treatment in $5 \% \mathrm{H}_{2} \mathrm{SO}_{4}$. However, the inline specimens, as before, could not be defilmed completely. Some of the scale was again removed by pulling it from the surface with Scotch tape, but this was only partially effective and did not remove any of the underlying film. Very extensive defilming of one in-line coupon, 939A, was attempted. Even after many repetitions of the treatment with Scotch tape and of cathodic cleaning at current densities higher than usual, the coupon still showed a 0.1 -mg weight gain. Flakes of scale and a uniform coating of dark-gray film were still visible under the microscope.

A sample of the rustlike bulk scale from the in-line Zircaloy-2 holder was submitted for chemical analysis. The following composition by weight was reported: iron, $32 \%$; uranium, $32 \%$; zirconium, $7 \%$; sulfate, $11 \%$; copper, $1 \%$; nickel, $2 \%$; and chromium, $0.1 \%$. 


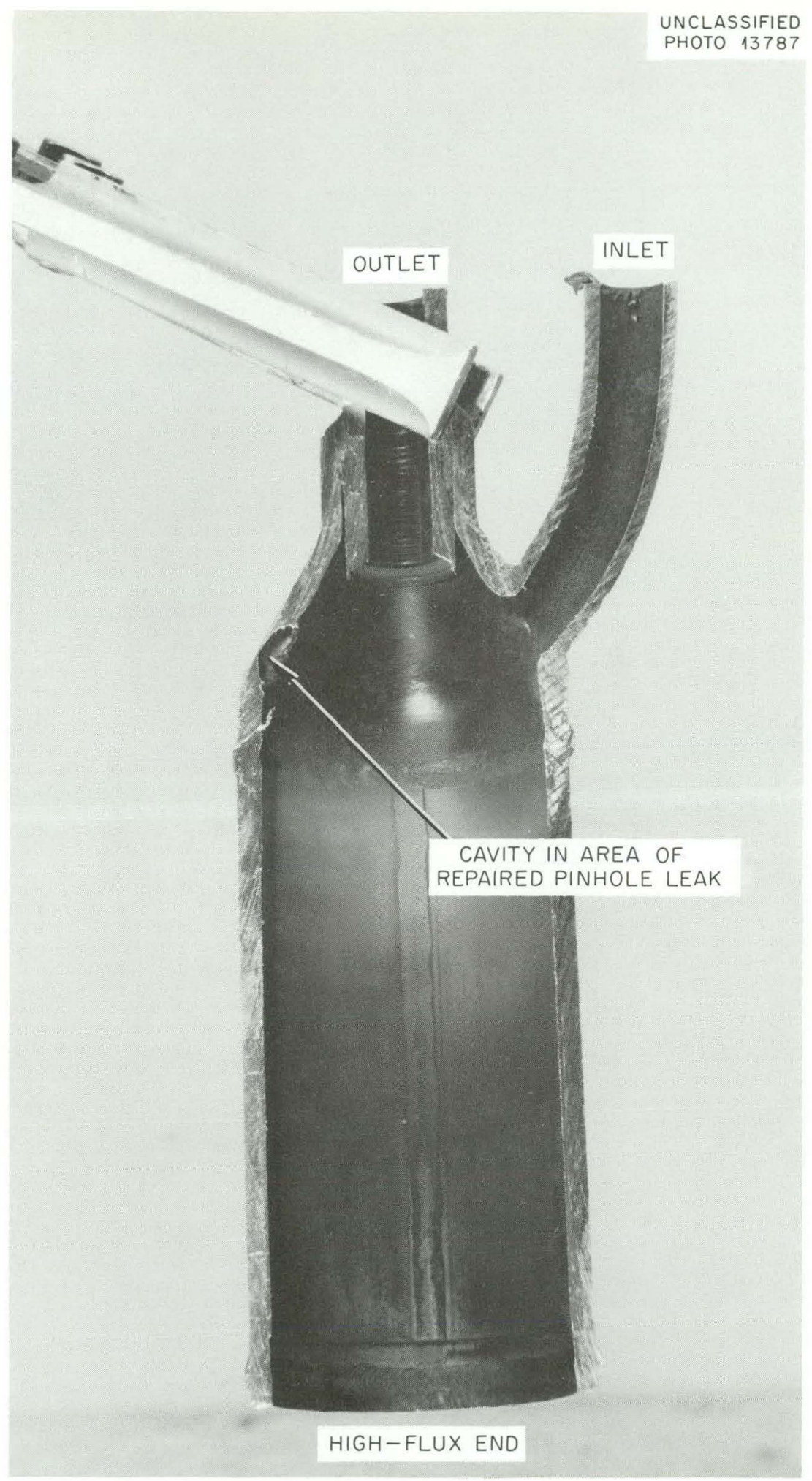

Fig. 44. Type 347 Stainless Steel Core Section, as Removed from Loop FF. 


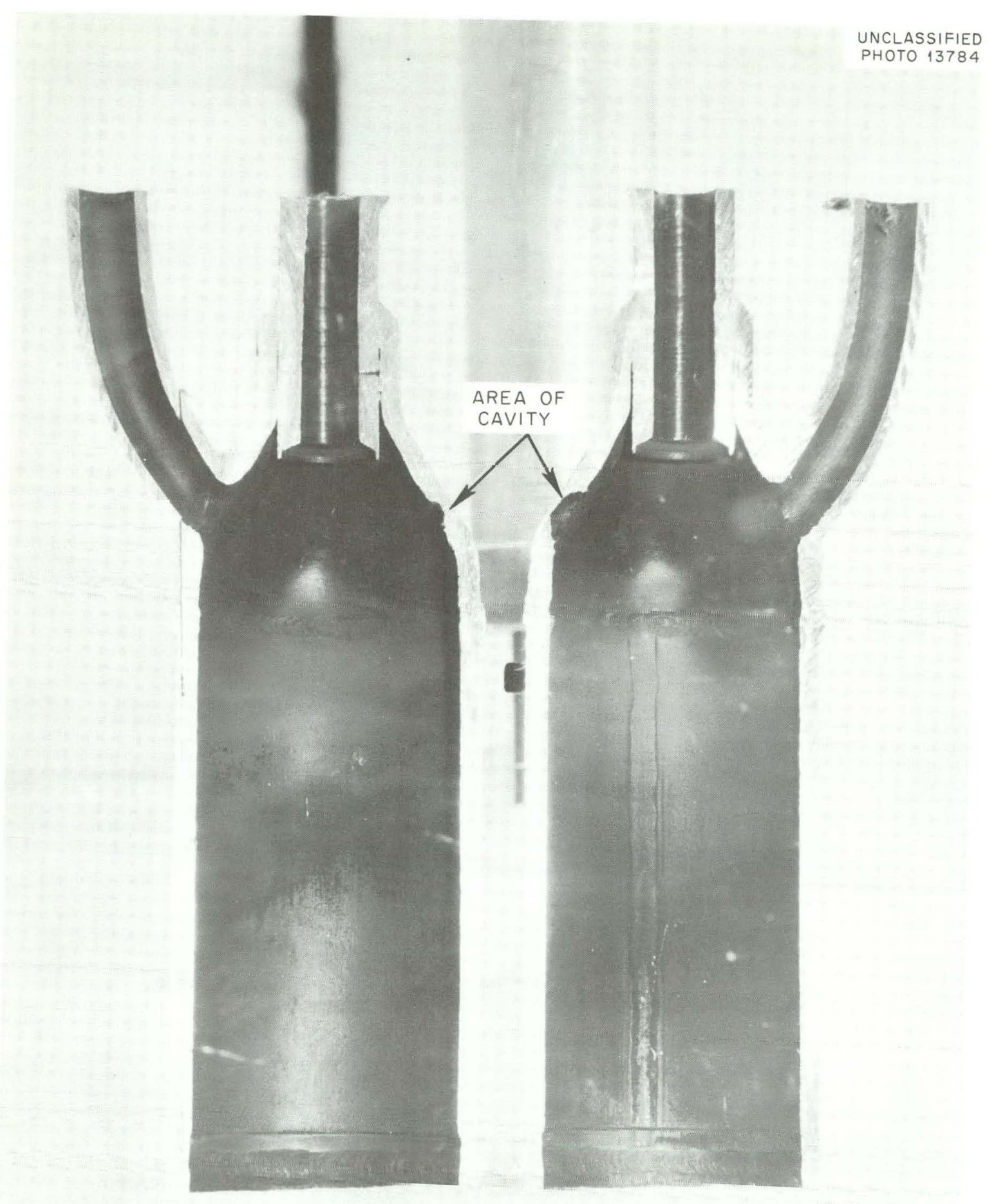

Fig. 45. Type 347 Stainless Steel Core Sections, as Removed from Loop FF. 


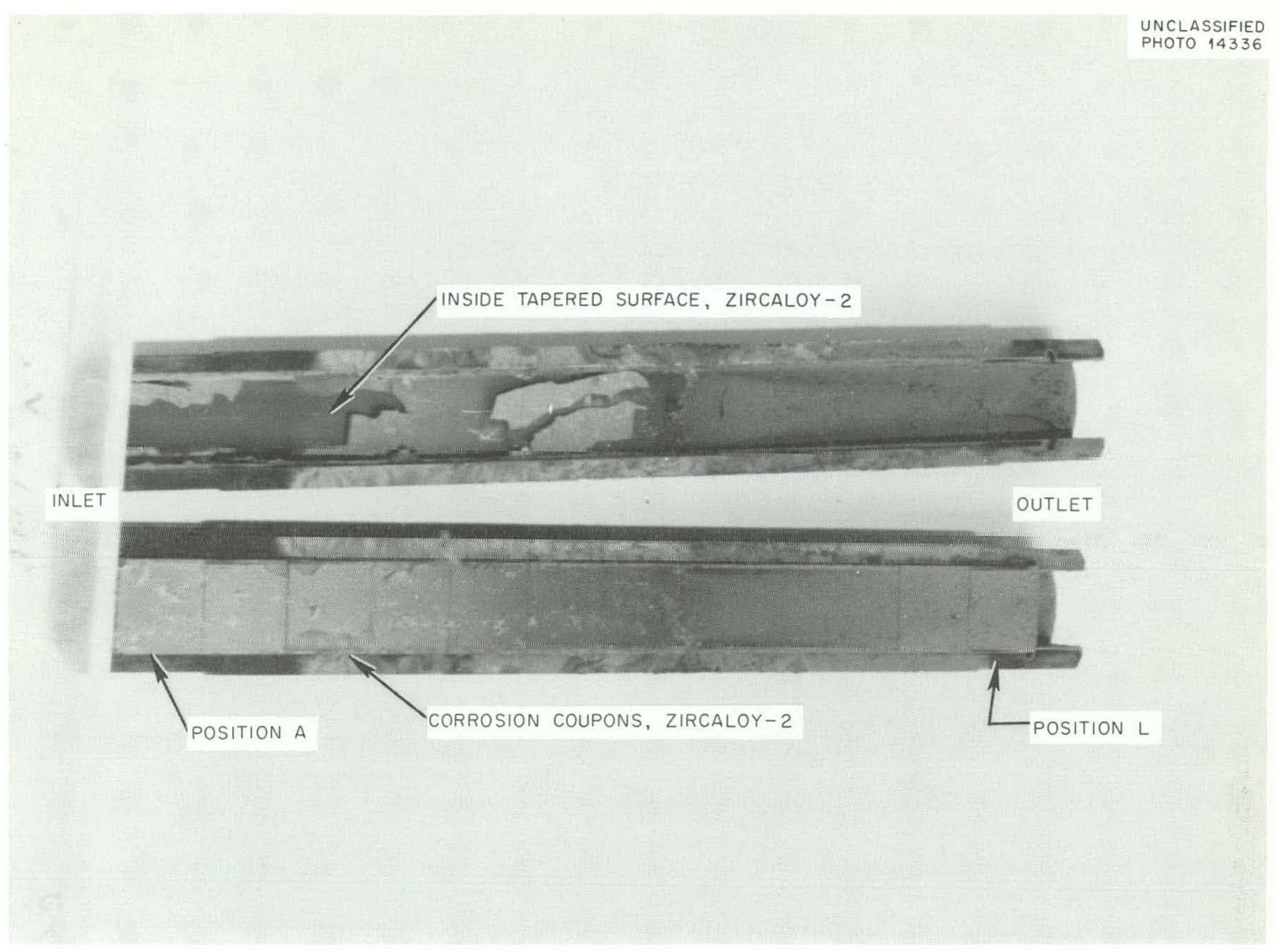

Fig. 46. In-Line Coupon Assembly, Loop GG.

\subsubsection{Loop EE}

As with previous loops, GG, FF, and DD, all surfaces outside the core were covered with a rustlike scale; there was no evidence of localized attack on any of the components inspected.

In the core area, all the stainless steel components were covered with a less bulky scale of similar rustlike appearance. The various titanium specimens were covered with a very thin rustlike scale, which, in general, became more bulky with decreasing flux. In contrast to previous findings for loops DD, FF, and GG, not all the Zircaloy-2 surfaces in the higher-flux regions were free from the rustlike scale. The core coupon holder and the stress specimens which were mounted in the spider around the coupon holder were free from bulk oxide deposits in the higher-flux regions. The Zircaloy-2 coupons inside the tapered holder, the coupons in the couple assemblies, and the spacers in the Zircaloy-2 couple assembly were coated with some deposited bulk scale in even the highest-flux region. The amount of this deposit, however, appeared to be inversely proportional to the flux, as usual.

A photograph of the core assembly as removed from the loop is shown in Fig. 48. The stainless steel couple assembly, a titanium stress assembly, and the Zircaloy-2 couple assembly are in the foreground. 


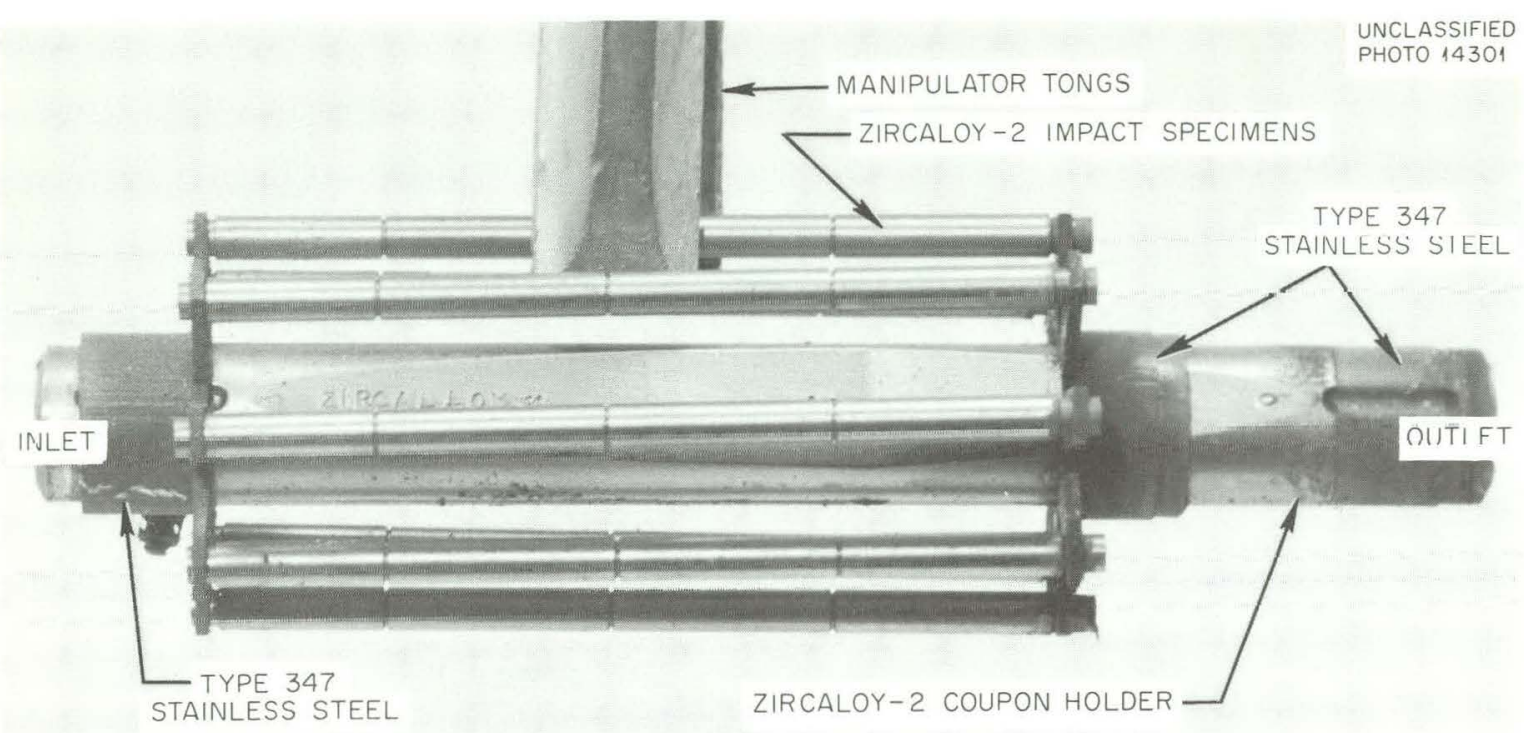

Fig. 47. Core Specimen Assembly, Loop GG.

As noted in Table 37, each titanium stress specimen exhibited a peculiar color pattern in the neighborhood of the fulcrum. This pattern can be seen in the photograph. The gradation of the quantity of scale with flux can also be seen in Fig. 48.

Microscopic examination of all the surfaces of all the stress specimens revealed no sign of stresscorrosion cracking in the type 347 stainless steel, Zircaloy-2, and titanium-55AX tested during this run.

The first three stainless steel coupons in positions 4,5 , and 7 of the core channel showed a concentration of attack in the exposed areas, with the clamped edges being protected. There was no such pattern of attack on the Zircaloy-2 or titanium coupons.

Surface examination of the various couple assemblies showed no pattem which would indicate an electrolytically enhanced corrosion rate for any of the six combinations tested. There were, however, indications of increased attack in crevice areas such as the essentially stagnant area between the spacers and rods of the couple assemblies. This was particularly true of the Zircaloy assembly, where corrosion product sealed the spacers to the rod. Disassembly of this rod required a screw-jack arrangement. Microscopic examination of the couple coupons indicated that the actual contacting spots were attacked less than were the adjacent areas in which surface roughness prevented perfectmatching. This could be an indication either of protection of the contact zone or increased corrosion in the crevice. The total corrosion was too small for any difference in appearance between the crevice surfaces and the free surface of the same coupon to be determined.

The core-reducer section of this loop contained a repaired pinhole similar to the one reported for loop FF. There was no sign of a cavity or of localized attack in or around the region of the repair weld. 


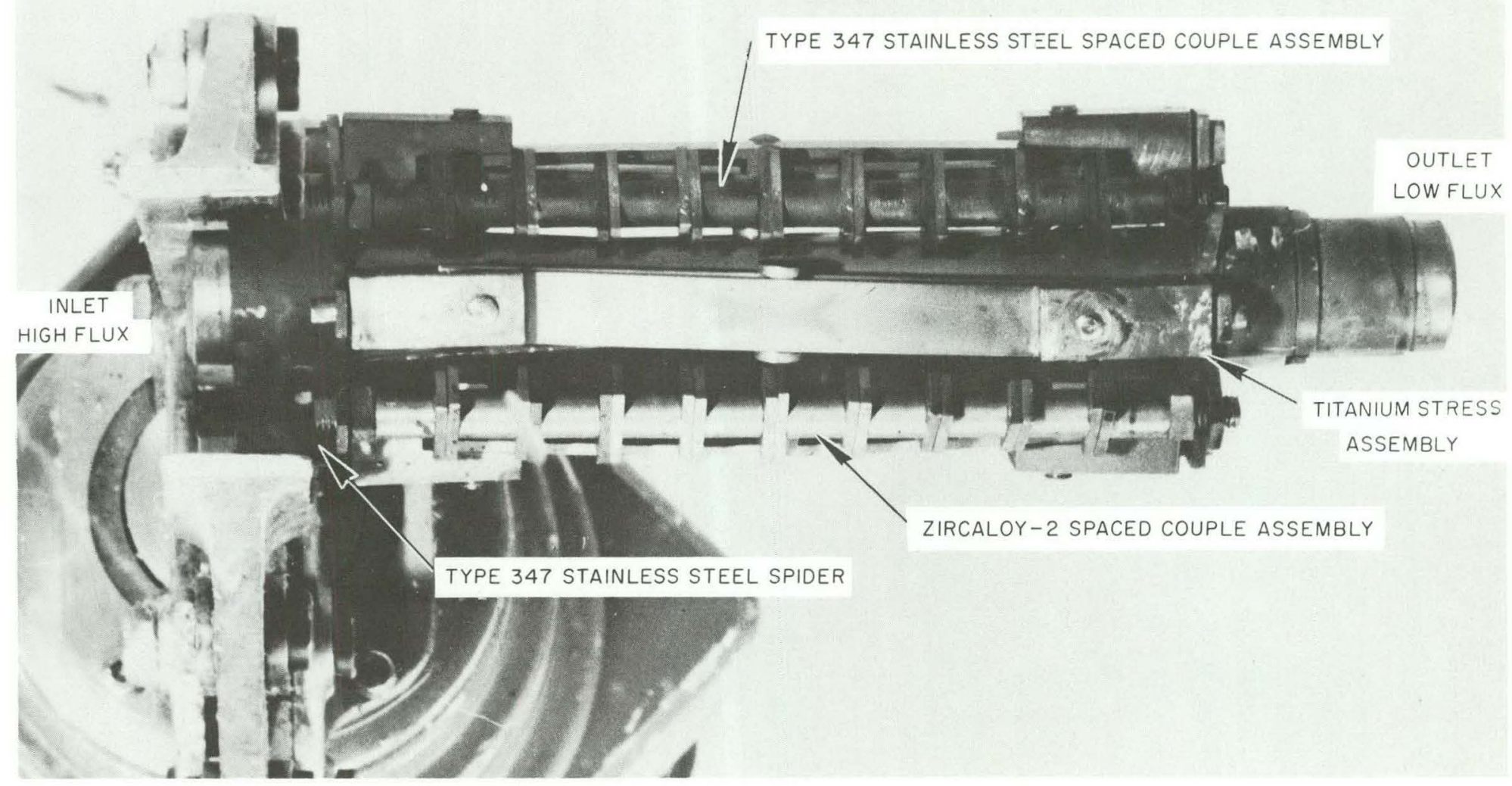

Fig. 48. Core Specimen Assembly, Loop EE. 


\subsubsection{Loop L-4-12}

All stainless steel surfaces in the core region (titanium core) were covered with a heavy black scale. The Zircaloy-2 impact specimens and stress specimen holders were covered with a thin film that produced interference colors. All titanium surfaces were covered with a brass-colored film. Both inside and outside titanium holder surfaces and the interior titanium core surface exhibited an additional, dark, rustlike scale at the rear, low-flux portion of the core. The core specimen array as removed is shown in Fig. 49. The first three stainless steel CC coupons in the high-flux region (positions 4,5 , and 7) were found to be missing when the core holder was opened. These specimens could not be found in any of the other loop components and it was concluded that they were dissolved. Examination of the titanium holders revealed two disturbed film markings on each side of the channel, located approximately where the leading edge of two of the missing coupons should have been. These markings indicated that the coupons left the array before termination of the in-pile run.

All component surfaces outside the core were covered with a heavy rustlike scale. The scale deposit was heavier on the wall in the liquid-phase region of the pressurizer than in the vapor-phase region. Unlike the pressurizer wall, the stainless steel and titanium stress specimens located in the pressurizer vapor and liquid regions showed little difference in appearance; however, the specimens from the liquid region exhibited greater increases in the as-removed weights than did the specimens from the vapor region.

Five LC coupons located in consecutive positions near the outlet of the holder [two Zircaloy-2 (positions 20 and 23), two titanium-55A (positions 19 and 22), and one type 347 stainless steel (position 21)] showed absence of film and heavy attack on the clamped areas which destroyed the identification numbers. Examination of these coupons with a stereomicroscope revealed evidence that they had not been held firmly in place. Previous out -of-pile experience in dynamic pump loops ${ }^{12}$ has shown that when a specimen is not held firmly the vibration during operation may prevent the accumulation of a protective film on the clamped edges and may lead to an increased attack in these areas. The mating surfaces of the two titanium holder halves in the vicinity of the five coupons, unlike the remaining holder area, were not filmed over.

Two type 347 stainless steel LC coupons, one adjacent to each end of the five-coupon group, showed heavy attack on their edges but were film-covered. The single Inconel LC coupon was also heavily attacked. The LC coupon assembly as removed is shown in Fig. 50.

Some localized attack occurred in the type 347 stainless steel pump volute. A single pit was located in the surface of the recessed shoulder at the volute inlet. The pit appearance is suggestive of the triangular-shaped pits found in stainless steel specimens located in the critical-flow velocity range in out-ofpile experiments. ${ }^{13}$

\footnotetext{
${ }^{12}$ J. C. Griess, HRP Quart. Progr. Rept. July 31, 1954, ORNL-1772, p 78.

${ }^{13} \mathrm{~J}$. C. Griess and R. E. Wacker, HRP Quart. Progr. Rept. Apr. 30, 1954, ORNL-1753, pp 76-77.
} 


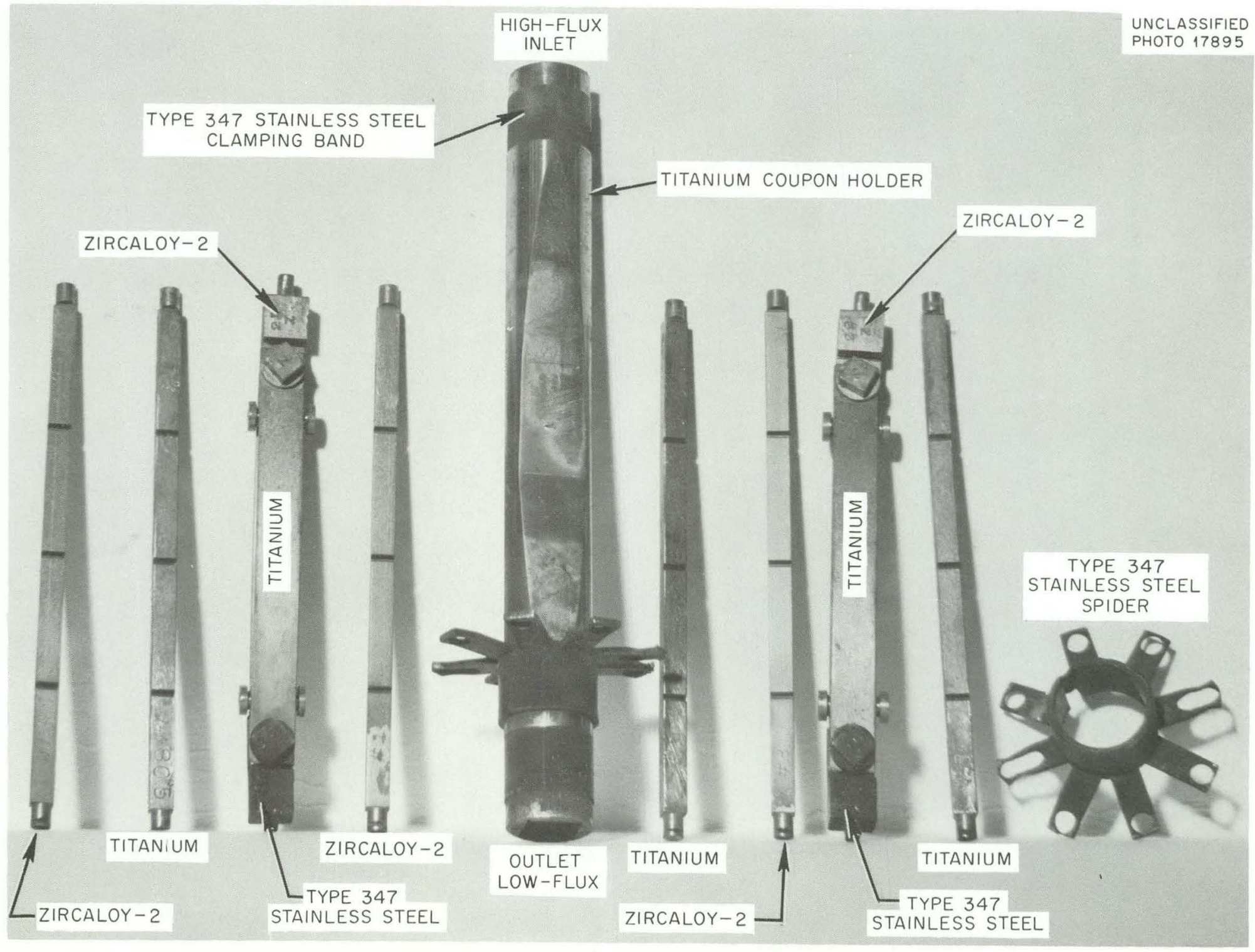

Fig. 49. Core Specimen Array as Removed, Loop L-4-12. 


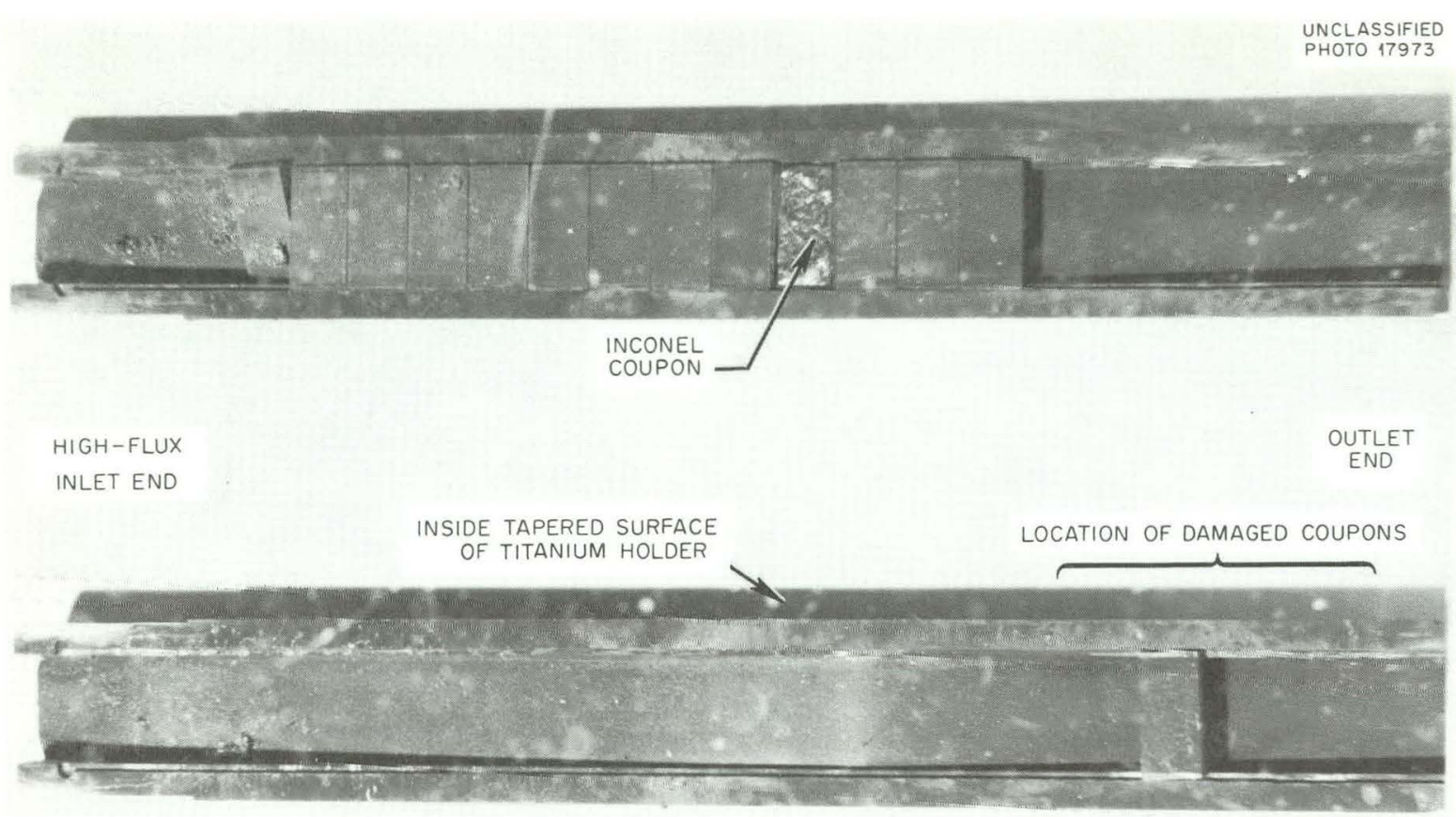

Fig. 50. In-Line Coupon Assembly, Loop L-4-12.

Separation of the titanium core from the stainless steel inlet pipe was accomplished easily by unscrewing the coupling. The titanium core-to-stainless steel outlet-pipe coupling was sectioned without dismantling. No evidence of galvanic attack was noted on either coupling, and all sealing surfaces appeared to be in excellent condition, as shown in Fig. 51.

As with all previous loops, cathodic defilming of the LC coupons was only partially effective; some film was retained by the specimens. In fact, all Zircaloy-2 LC coupons (excluding loose coupons in positions 20 and 23) showed weight increases or no weight change following the final defilming. The CA and LA impact specimens were not defilmed. A brief description of each specimen from theloop, as removed and following defilming, is given in Table 41.

\subsubsection{Loop L-4-13}

All loop component surfaces outside the core were covered with scale that was heavy dark-brown and rustlike in appearance except in the pressurizer. The scale in the liquid-phase portion of the pressurizer washeavy and black, while only a thin dark-gray film was found on the surfaces in the vapor-phase region.

There was no evidence of localized attack on any of the components, including the pump impeller and volute. Further examination of the pressurizer revealed that the normal oxygen addition port had been submerged in solution during operation and had become plugged with some of the heavy scale. This finding provides the explanation for oxygen addition difficulties encountered during the run. The submersion was caused by a combination of factors. The capillary entrance was not on the vertical center line, the pressurizer was tilted from the horizontal, and the liquid level in the pressurizer was higher than usual. 


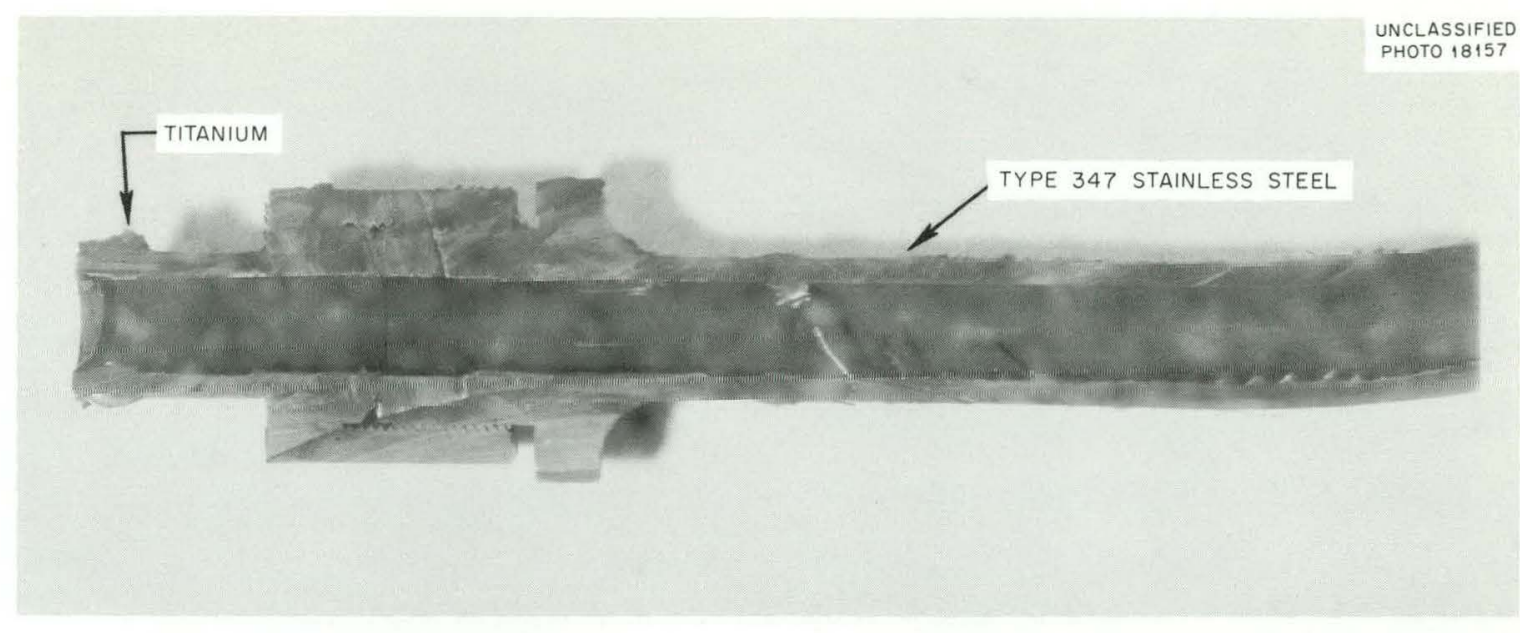

Fig. 51. Titanium-to-Stainless Steel Pipe Coupling on Core Outlet Line, Loop L-4-12.

All specimens outside the core were also uniformly coated with a heavy rustlike scale. As with all previous loops, cathodic defilming of the in-line coupons was only partially effective. All crystal-bar zirconium in-line coupons except one showed weightincreases following the final defilming. The in-line impact specimens were not defilmed.

The interior of the core body and the exterior of the core channel holder, both fabricated from type 347 stainless steel, were covered with a two-colored scale. The scale at the forward, or high-flux, position was soft and sooty-black in appearance, while the low-flux end was covered with a harder, rustlike brown scale. The interior surfaces of the core channel holder and all the contained stainless steel coupons (types $309 \mathrm{SCb}$ and 347) were covered with a dark-gray to black scale, increasing in thickness from front to rear. All the crystal-bar zirconium CC coupons were covered with a thin iridescent film but no scale. Figure 52 is a photograph of the core holder and coupons after removal from the loop.

In disassembling the core body the impact and tensile specimens located in the annular region became loosened and fell from the holders. The single titanium tensile specimen was covered with a uniform gray film. The Zircaloy-3a tensile and impact specimens were free from scale and were covered with a thin iridescent film, while the $\mathrm{Zr}-20 \% \mathrm{Nb}$ impact specimens were covered with a uniform, tightly adherent, thin dark scale.

\subsubsection{Loop L-4-18}

The loop components outside the core region were generally covered with a relatively thin dark-gray to dark-brown-black rustlike scale. The vapor region of the pressurizer was almost free of this scale, particularly at the outlet end. The liquid region of the pressurizer was uniformly covered with a heavy, black, velvet-like scale. There was no evidence of localized attack on any of the components examined. 

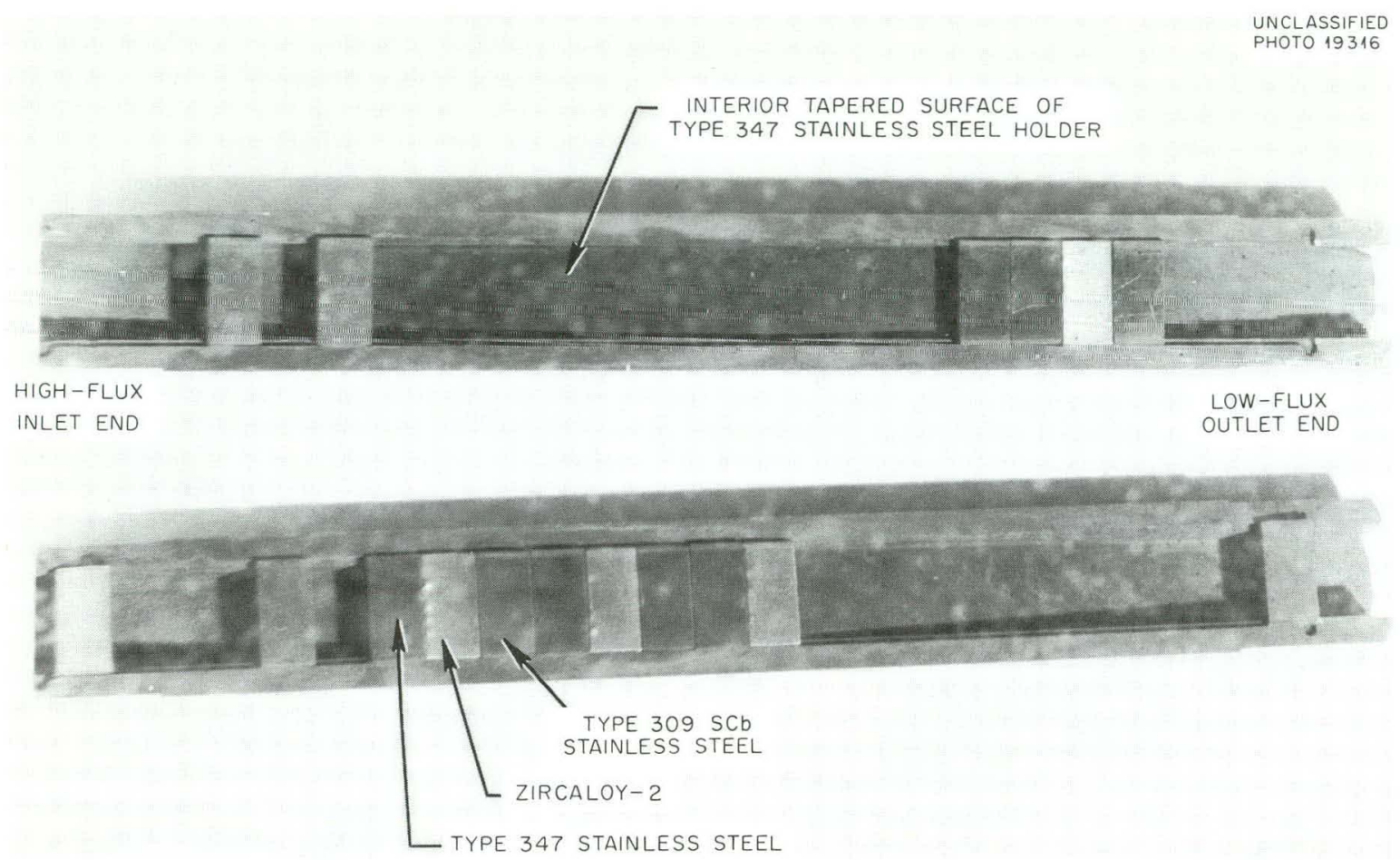

Fig. 52. Core Coupon Array, Loop L-4-13.

All the stainless steel and Zircaloy-2 coupons in the LC array were covered with the rustlike scale. The type 430L stainless steel LA coupons were covered with a light-gray scale with an overlay of darkbrown to black scale, while the type 347 stainless steel coupons contained in the same array were covered with a darker gray scale and a similar overlay. The Zircaloy-2 and $\mathrm{Zr}-15 \% \mathrm{Nb}$ coupons contained in the second LA array were covered with dark shiny scales and some dark-brown scale, with the $15 \% \mathrm{Nb}$ alloy scale being darker and showing some grain patterns. The $\mathrm{Ti}-55 \mathrm{~A}$ and $\mathrm{Ti}-3 \% \mathrm{Al}$ coupons from the same array were covered with heavy bronze-colured scale and spots of the dark-brown, transported scale.

The interior surfaces of the type 347 stainless steel core body and the type 347 stainless steel core coupon holders, spiders, and coupons were covered with a glossy rust-colored scale in the high-flux end of the core. This scale tapered gradually into a thick, dull, black scale at the low-flux end. The type 430L stainless steel coupons were similar in appearance to those in the LA coupon array. The Zircaloy-2 coupons and stress specimens were generally covered with a thin iridescent film which was predominatly gray, but with varying amounts of brown flakes of scale retained on the surfaces. The apparent film thickness and amounts of retained scale increased with decreasing flux. The Zr-Nb alloys were covered with a dark scale in a definite grain pattern, with some retained flakes of dark-brown scale. The Ti-55A coupons were covered with the typical, thin bronze-colored film. The Ti-Al alloy coupons also were covered with a shiny bronze film, but all the surfaces had a rough, etched appearance. 
As with previous loops, repeated attempts to defilm the zirconium and titanium alloys by the standard cathodic defilming technique were only partially effective, and some scale was retained.

Although the pump in this experiment had failed in service, it was noted that the impeller rotated freely and that there was adequate end play before the pump was dismantled. After the pump was dismantled, examination of the rotor can and of the aluminum oxide bearings and joumals showed no evidence of wear. The shaft in the region of the thermal barrier and the barrier itself were also examined. Although no evidence of localized attack was apparent, the appearance of the surface scale in different positions in this region varied markedly. The first three rings of the barrier at the high-temperature end were free from any scale accumulations, while the remainder of the barrier was covered with a dark-brown-black scale. The appearance of the scale changed along the shaft. In the low-temperature region, the shaft exhibited a light-gray, essentially film-free surface. The portion of the shaft.in the scale-covered barrier region was also covered by a similar band of scale.

Samples of the bulk scale wcre siraped from the rear of the core, the in-line annulus holders, the pressurizer, and the pump volute and were submitted for chemical analyses. In addition, analyses were performed on solutions of the scale from one-half of the type 347 stainless steel core coupon holder. The results of these analyses are in a following section.

\subsection{Metallographic Examination of Loops}

Metallographic findings for the corrosion specimens and loop component specimens have been reported. ${ }^{14-22}$ Representative corrosion coupons from core and in-line positions, stress corrosion specimens, and loop component specimens, including sections from the core body, pressurizer and pressurizer heater, pressurizer thermocouple well, pump outlet piping, sampler-line capillary tubing, coupon holder assembly, pressurizer inlet line restrictor, and various weld sections, were examined. Impact and tensile

\footnotetext{
${ }^{14}$ M. J. Feldman et al., Metallographic Examination of Coupons and Components of HRP In-Pile Loop "DD," ORNL CF-55-2-73 (Feb. 9, 1955).

${ }^{15} \mathrm{M}$. J. Feldman et al., Metallographic Examination of HRP In-Pile Loop "FF" Components, ORNL CF-55-154 (May 16, 1955).

${ }^{16}$ A. E. Richt and J. O. Stiegler, Metallographic Examination of Zircaloy-2 Coupons from HRP In-Pile Loop "FF :" ORNL CF-56-8-48 (Aug. 8, 1956).

${ }^{17}$ A. E. Richt, Metallographic Examination of HRP In-Pile Loop "EE" Cumponents and Coupons, ORNL CF56-7-17 ( J uly 6,1956$)$.

18 A. E. Richt, Metallographic Examination of Components and Coupons from HRP In-Pile L-4-18, ORNL CF 58-4-30 (Apr. 3, 1958).

${ }^{19} \mathrm{~J}$. O. Stiegler, Metallograpbic Examination of Components and Coupons from HRP In-Pile Loop "GG." ORNL CF-57-3-83 (Mar. 19, 1957).

${ }^{20} \mathrm{~J}$. O. Stiegler, Metallographir Examination of Components, Coupons and Stress Corrosion Specimens from HRP In-Pile Loop L-4-12, ORNL CF-57-2-88 (Feb. 19, 1957).

$21 \mathrm{~J}$. O. Stiegler, Supplementary Metallographic Examination of Titanium Stress Corrosion Specimens from HRP In-Pile Loop L-4-12, ORNL CF-57-8-54 (Aug. 9, 1957).

$22 \mathrm{~J}$. O. Stiegler, Metallographic Examination of Components and Coupons from HRP In-Pile Loop L-4-13, ORNL CF-57-3-140 (May 10, 1957).
} 
specimens were submitted in the as-removed condition to the Metals and Ceramics Division for examination and testing. ${ }^{23,24}$ Interior surfaces of typical sections of the loop components, all surfaces of representative cross sections of the coupons, and both the tension and compression surfaces of stress specimens were examined. In addition, coupon thicknesses were measured to determine general surface removal and the location and extent of regions of localized attack. Summaries of the examination of the corrosion coupons, stress corrosion specimens, and loop components are given in Tables 30-32.

In general, corrosion estimates from thickness measurements and metallographic observations of the corrosion coupons were in near agreement with the weight-loss data. Also, the results for specimens and loop components exposed at negligible fission-power densities show that corrosion was not appreciably different from that expected out-of-radiation. Evidence for exceptionally severe corrosion or surface cracking was found in several cases. However, these effects, in general, were not considered results of the radiation exposures but, rather, results of such factors as poor specimen material, mechanical damage in the specimen mounts, and, in the case of some of the surface cracks, fabrication techniques.

Brief summaries of the metallographic results are given in the following paragraphs. Those results indicating exceptional corrosion behavior are included.

\subsubsection{Stainless Steel Corrosion Coupons}

Corrosion of the stainless steel coupons exposed to fission recoils was generally of the type that commenced with the production of pits of about 1 mil in depth, which then spread laterally.

Type 347 stainless steel CC coupon 437A (loop DD) showed a "shouldering" effect where the coupon was protected by the sample holder. Near this edge, general surface removal was approximately $1 \frac{1}{2} \mathrm{mils}$. Near the center of the coupon, thickness measurements showed approximately $2 \frac{1}{2}$ mils of surface removal. There was also some evidence of corrosive penetration at the grain boundaries, especially near the center of the coupon. The appearance of the "shoulder" on this coupon is shown in Fig. 53.

Type 347 stainless steel CC coupon 743 A (loop EE) exhibited significant surface removal. In this instance the attack was not of the pitting type; however, there appears reason to suspect that this coupon was improperly mounted in the sample holder in such a way as to significantly affect the corrosion rate. A photomicrograph of a section of this coupon is shown in Fig. 54.

Type 347 stainless steel LC coupon 1126A (loop L-4-12), located adjacent to the five loosened and damaged coupons, had smooth surfaces except at one corner, which had been removed. Figure 55 is a micrograph of the damaged end of this coupon.

Two type 347 stainless steel CC coupons 1022A and 1027A (loop L-4-13) were examined and showed unusually severe pitting attack up to a depth of 3 mils on all surfaces. The pits were more frequent and deeper on coupon 1022A than on coupon 1027A. Thickness measurements of both coupons showed little or no general surface removal. One of the more severely pitted areas of coupon 1022A is shown in Fig. 56.

\footnotetext{
${ }^{23}$ W. J. Fretague, HRP Quart. Progr. Rept. Apr. 30, 1955, ORNL-1895, p 167.

${ }^{24}$ W. J. Fretague, HRP Quart. Progr. Rept. July 31, 1955, ORNL-1943, pP 167-68.
} 
Table 32. Summary of Metallographic Examinations of Components

\begin{tabular}{|c|c|c|c|}
\hline Experiment & Component $^{a}$ & Metallographic Observations & Figure Number \\
\hline \multirow[t]{5}{*}{ DD } & Core cap & $\begin{array}{l}\text { Interior surface appeared roughened but showed no evidence of inter- } \\
\text { granular corrosive attack or cracking; the initial surface was } \\
\text { probably rough }\end{array}$ & \\
\hline & Pressurizer (liquid phase) & Indication of corrosive attack; some penetration at the grain boundaries & 65 \\
\hline & Pressurizer (vapor phase) & Indication of corrosive attack; some penetration at the grain boundaries & \\
\hline & Loop piping at pump outlet & No indication of corrosive penetration & \\
\hline & Pressurizer heater & No indication of corrosive penetration & \\
\hline \multirow[t]{8}{*}{ F F } & Core cap & Corrosive penetration to about $1 / 2-$ mil depth & \\
\hline & Pressurizer (inlet end) & No evidence of corrosive attack & \\
\hline & Pressurizer (outlet end) & Approximately $\frac{1}{4}$-mil corrosive penetration at grain boundaries & \\
\hline & $\begin{array}{l}\text { Pressurizer thermocouple well } \\
\text { (external surface) }\end{array}$ & $\begin{array}{l}\text { No evidence of corrosive attack } \\
\text { Large pit noted in weld metal; approximately } 1 / 2 \text {-mil corrosive penetration }\end{array}$ & \\
\hline & Core body weld at reducer & in adjacent heat-affected zones & 63 \\
\hline & Pressurizer heater (inlet and outlet) & No evidence of corrosive attack & \\
\hline & Loop piping at pump outlet & No evidence of corrosive attack & \\
\hline & Core reducer & $\begin{array}{l}\text { Approximately } \frac{1}{2}-\text { mil corrosive penetration; tendency toward intergranular } \\
\text { type of attack }\end{array}$ & \\
\hline \multirow[t]{8}{*}{ GG } & Core cap & Very rough; evidence of intertranular attack to a depth of approximately & \\
\hline & & $1 \mathrm{mil}$ & 62 \\
\hline & $\begin{array}{l}\text { Pressurizer heater lines (inlet and } \\
\text { outlet) }\end{array}$ & No evidence of corrosive attack; covered with $1 / 2$-mil thick film & \\
\hline & Pump outlet piping & No evidence of corrosive attack; covered with $1 / 2$-mil thick film & \\
\hline & Pressurizer (inlet end) & No evidence of corrosive attack or film formation & \\
\hline & Pressurizer outlet (liquid phase) & $\begin{array}{l}\text { Slightly roughened surface; evidence of penetration at grain boundary; } \\
1 / 4 \text {-mil film present }\end{array}$ & \\
\hline & Pressurizer outlet (vapor phase) & $\begin{array}{l}\text { Slightly roughened surface; evidence of penetration at grain boundary; } \\
1 / 4-m i l \text { film present }\end{array}$ & \\
\hline & $\begin{array}{l}\text { Pressurizer thermocouple well } \\
\text { (external surface) }\end{array}$ & Smooth; no evidence of corrosive attack & \\
\hline
\end{tabular}


Table 32 (continued)

\begin{tabular}{|c|c|c|c|}
\hline Experiment & Component $^{a}$ & Metallographic Observations & Figure Number \\
\hline \multirow[t]{6}{*}{$\mathrm{EE}$} & Core cap & Very rough uneven surface with some indication of corrosive attack & \\
\hline & Pressurizer (liquid phase) & No evidence of corrosive attack & \\
\hline & Pressurizer (vapor phase) & Evidence of slight corrosive attack at grain boundaries & . \\
\hline & Pressurizer heater & No evidence of corrosive attack & \\
\hline & Pump outlet piping & No evidence of corrosive attack & \\
\hline & Core coupon holder clamping bands & Isolated corrosive attack on band at outlet end of holder & 66 \\
\hline \multirow[t]{7}{*}{$L-4-12$} & Core cap ${ }^{b}$ & Smooth; no evidence of corrosive attack & \\
\hline & Core body to reducer weld ${ }^{b}$ & Rough uneven surface; several 5-mil cracks emanating from inner surface & 64 \\
\hline & Pressurizer inlet and outlet & Rough, uneven surfaces; intergranular penetration to depth of about $1 \mathrm{mil}$ & \\
\hline & $\begin{array}{l}\text { Pressurizer thermocouple well } \\
\text { (external surface) }\end{array}$ & Uniformly roughened; intergranular penetration to depth of about $1 \mathrm{mil}$ & \\
\hline & Pressurizer heater inlet and outlet & No evidence of corrosive attack & \\
\hline & Pressurizer inlet line restrictor & $\begin{array}{l}\text { Smooth and free from attack with } 1 / 4-m i l \text { film; a limited area exhibited } \\
\text { slight roughening }\end{array}$ & \\
\hline & Pump outlet piping & No evidence of corrosive attack & $\cdot$ \\
\hline
\end{tabular}




\section{L-4-13 Core cap}

Pressurizer inlet and outlet

Pressurizer heater inlet, outlet, and U-bend

Pump outlet piping

L-4-18 Core cap

Pressurizer (liquid phase)

Pressurizer (vapor phase)

Pump outlet piping

Pressurizer heater inlet, outlet, and U-bend

Sample line capillary tubing
No evidence of intergranular penetration; surface irregularities of about 1 -mil depth beneath $1 / 4$-mil film

Rough with about $\frac{1}{2}$-mil maximum penetration at grain boundaries; covered with $1 / 4-$ to $3 / 4-$ mil film

Rough appearance with $\frac{1}{4}$ - to 1 -mil-thick films over all surfaces

No evidence of corrosive attack

Sporadic pitting attack to depth of $1 \frac{1}{2}$ mils; attack probably associated with stringering of inclusions in metal

Slight attack at grain boundaries; less than $1 / 4$-mil-thick oxide scale formation all surfaces

Slight attack at grain boundaries; less than $1 / 4$-mil-thick oxide scale formation all surfaces

No evidence of corrosive attack

Less than $1 / 4$-mil corrosive penetration at grain boundaries; no stresscorrosive effect observed in U-bend

Intergranular attack to 5 mils deep in area near loop piping junction; remainder of $3 / 8$-in.-long specimens showed intergranular penetration of about 1-mil depth; all surfaces covered with 2-mil oxide scale

\footnotetext{
${ }^{a}$ All components are 347 SS except as noted.

${ }^{b}$ Ti-55A.
} 


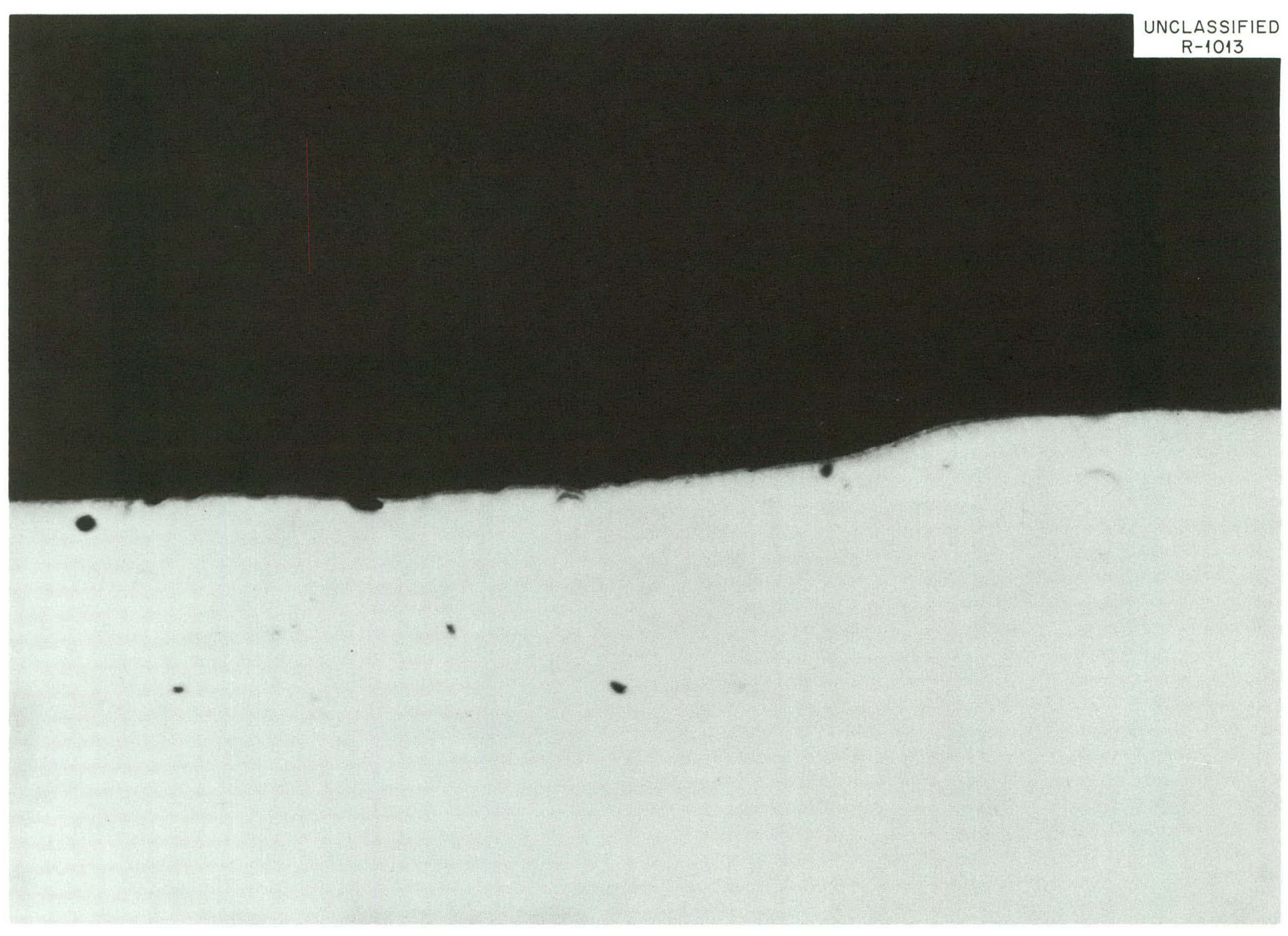

Fig. 53. Appearance of "Shoulder" Where Sample Holder Gripped Type 347 Stainless Steel, CC Coupon No. 437, Loop DD. 


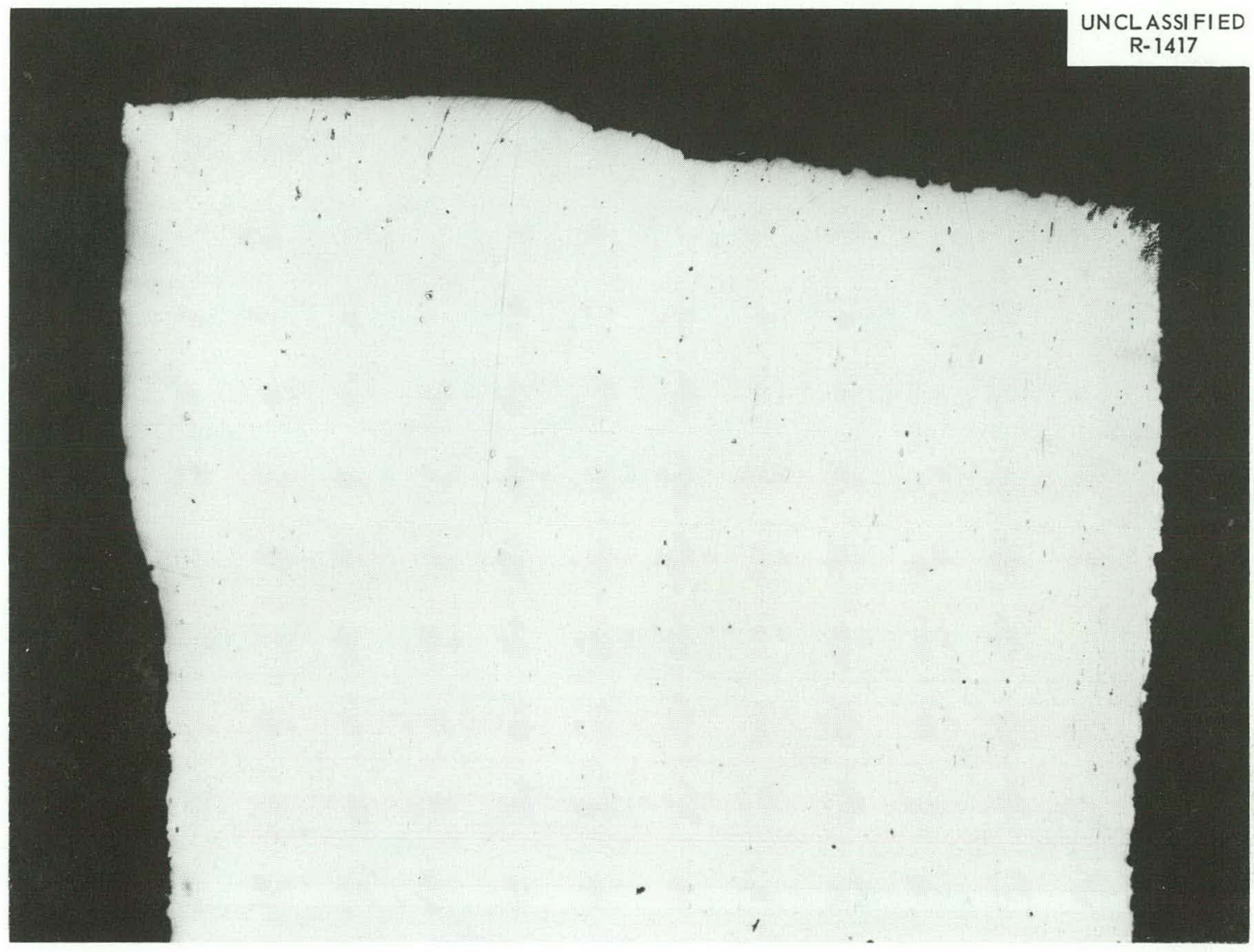

Fig. 54. Type 347 Stainless Steel - CC Coupon 743A, Loop EE. 80 X.

One of the four type $309 \mathrm{Cb}$ stainless steel coupons examined from loop L-4-13, LC coupon C-65, which showed the largest weight loss, was slightly roughened on all four corners and both ends, as shown in Fig. 57.

\subsubsection{Zirconium and Zirconium-Alloy Corrosion Coupons}

Crystal-bar zirconium, Zircaloy-2, and zirconium-15\% Nb coupons appeared smooth, in general, and showed no evidence of severe corrosive attack.

Zircaloy-2 CC coupon 948A (loop GG), however, showed slight surface roughening, and a 3-mil crack of unknown origin was observed near the center of one side (Fig. 58).

Three Zircaloy-2 CC coupons from experiment EE showed slight surface roughening. In addition, numerous pits approximately $\frac{1}{2} \mathrm{mil}$ in depth were observed in the coupon exposed to the highest fissionpower density. However, the frequency of such depth of attack was generally less than that shown on the stainless steel coupons. The Zircaloy-2 LC coupon from this experiment showed no evidence of corrosive attack. 


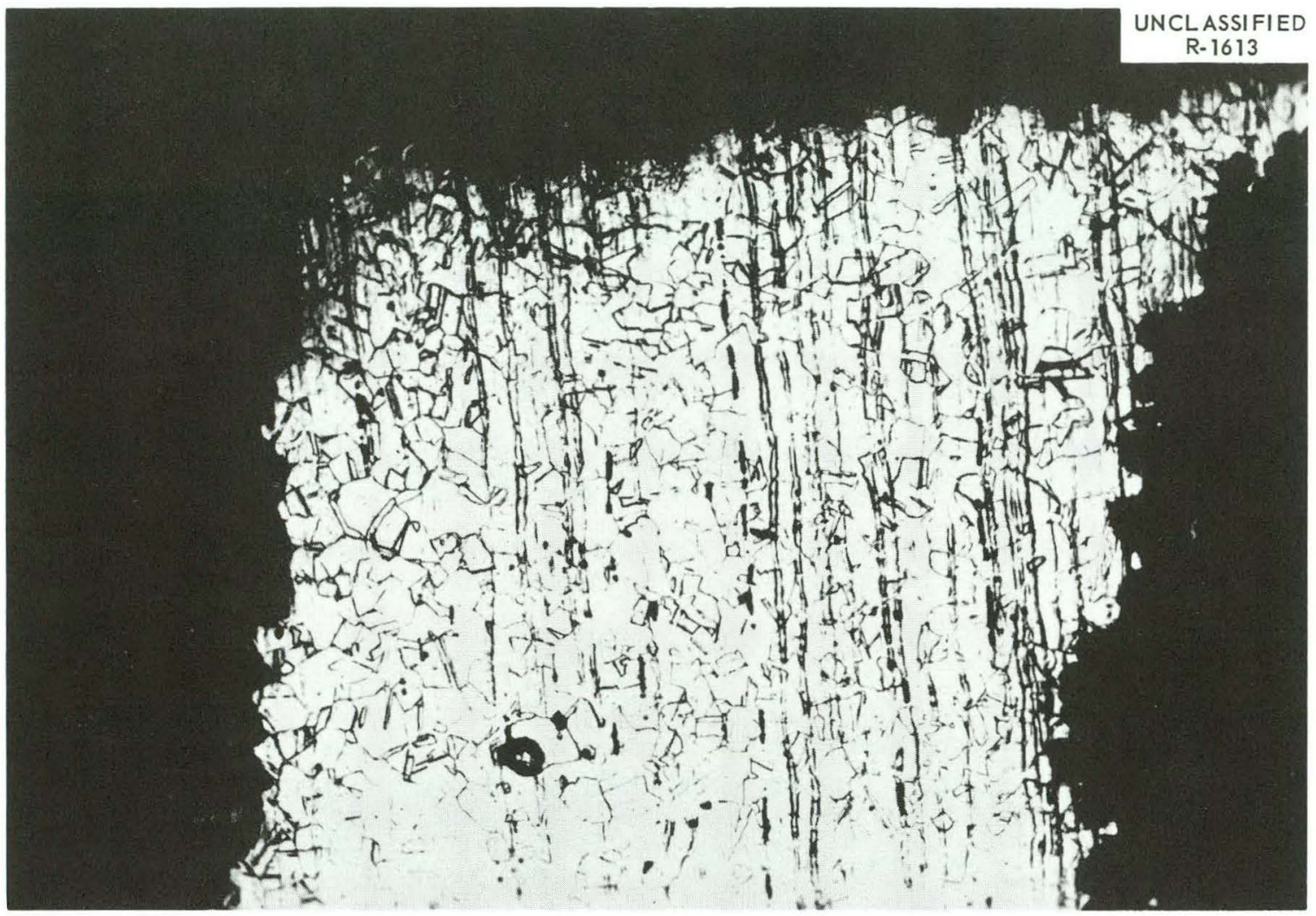

Fig. 55. End of Damaged Type 347 Stainless Steel - LC Coupon 1126A, Loop L-4-12. 250 X.

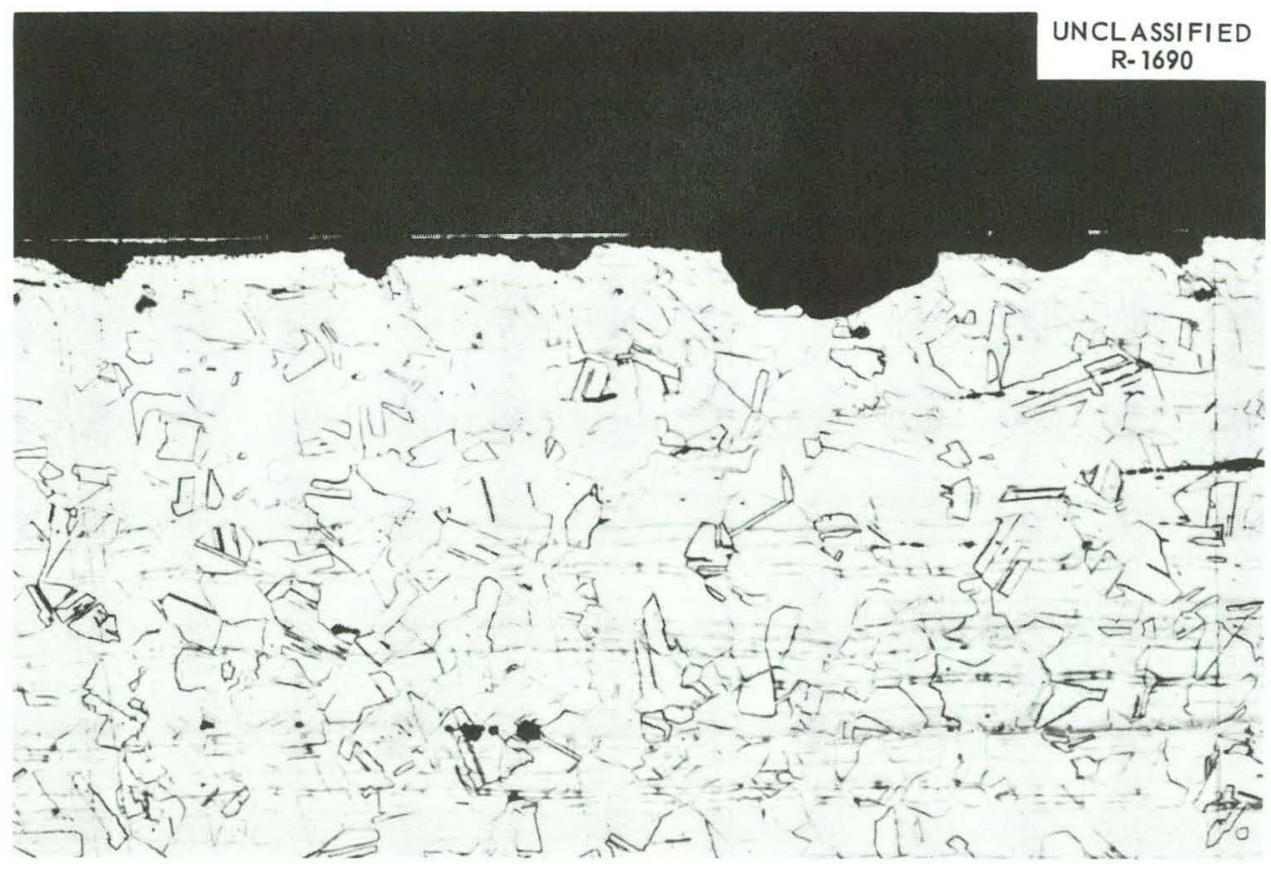

Fig. 56. Type 347 Stainless Steel - CC Coupon 1022A, Loop L-4-13. 250 X. 


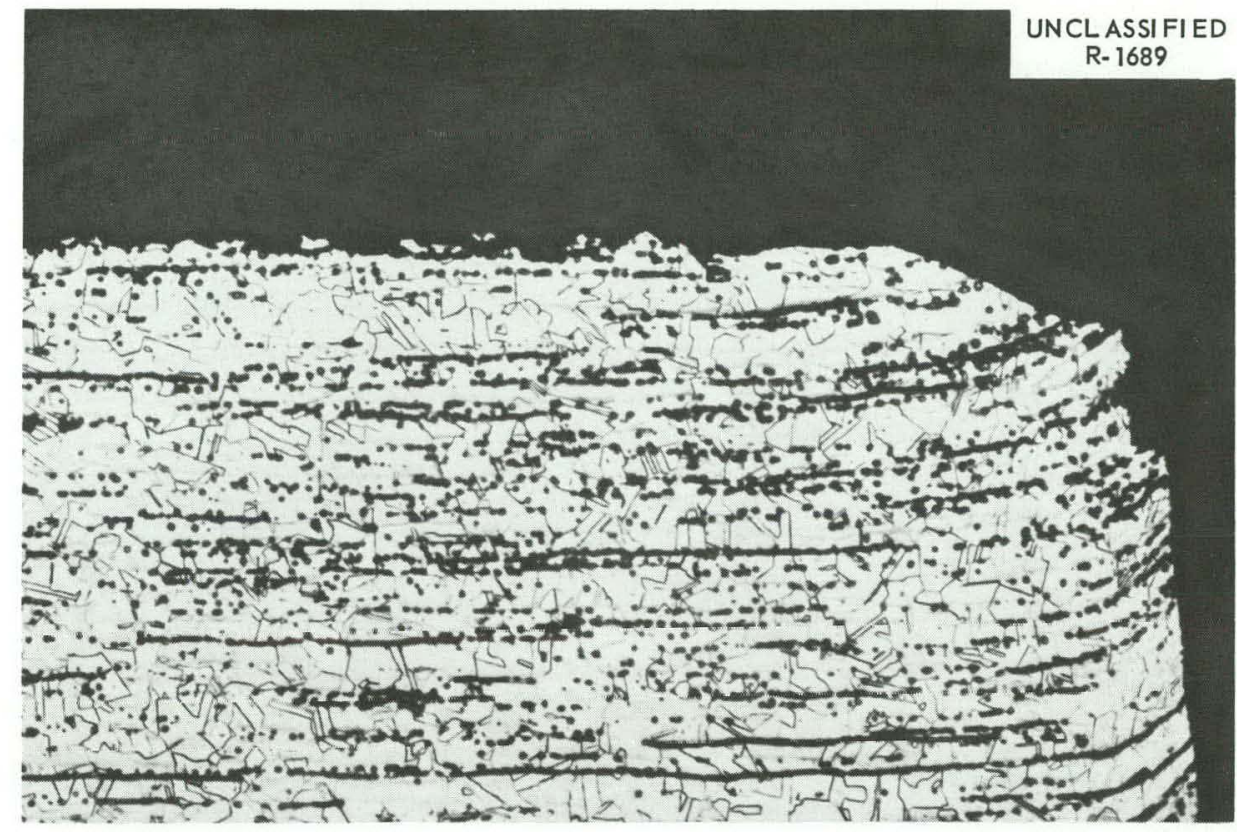

Fig. 57. Type 309SCb Stainless Steel - LC Coupon C-65, Loop L-4-13. 250 X.

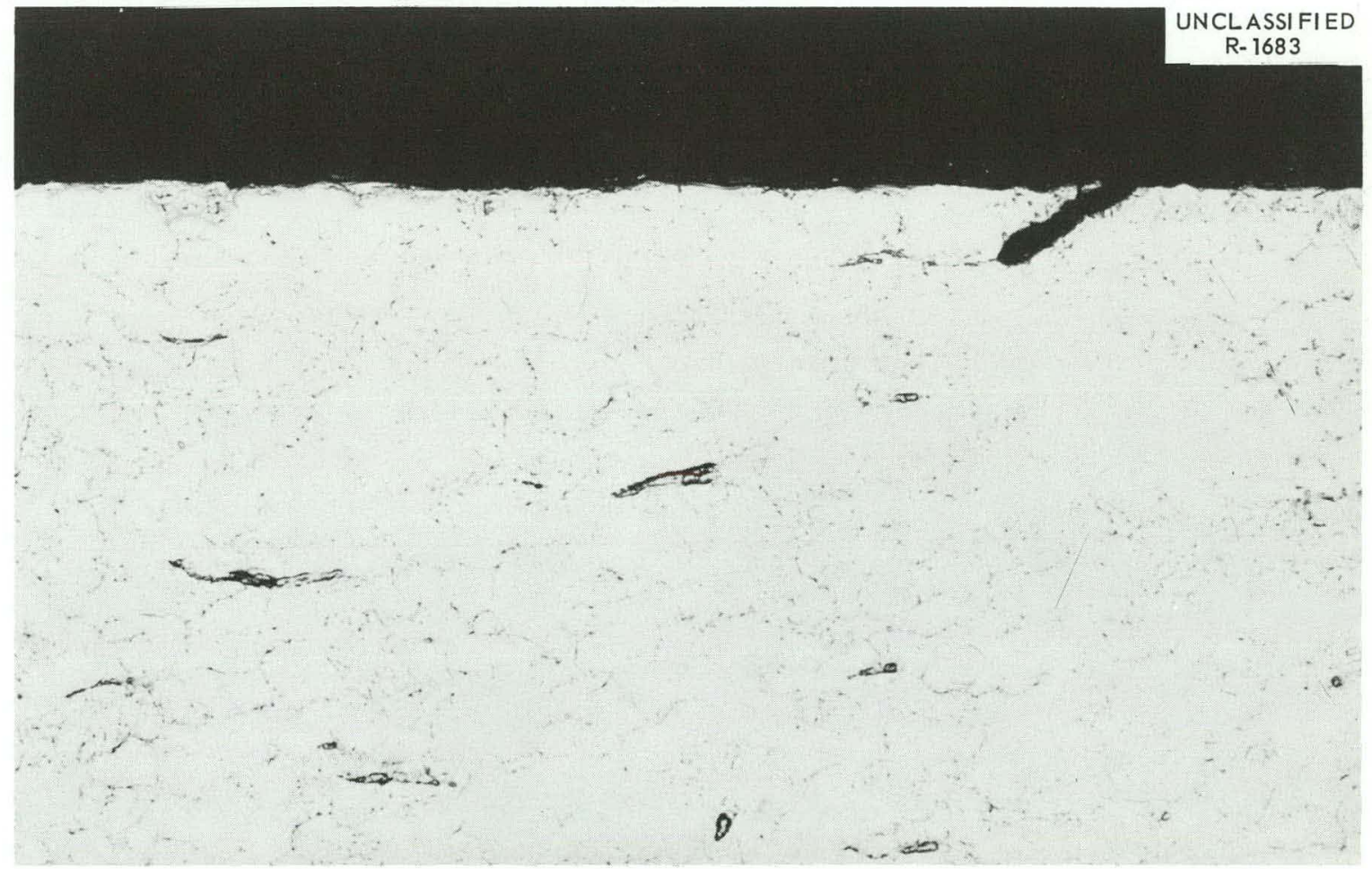

Fig. 58. Zircaloy-2 CC Coupon 948 A, Loop GG. 250 X. 
Attack on the two loose Zircaloy-2 LC coupons (loop L-4-12) was restricted to the normal clamping areas, while the exposed surfaces show no evidence of any surface removal. The smooth removal of clamping surface from one of these damaged coupons is shown in Fig. 59.

A crystal-bar zirconium LC coupon Z-115 (loop L-4-13) was severly attacked on both ends, and a re-

tained surface film about $\frac{1}{4} \mathrm{mil}$ in thickness was observed on two or three limited areas. Bright-field and polarized-light photomicrographs of a filmed region are shown in Fig. 60. Other coupons of this material showed only slight surface roughness, with no pits, cracks, or visible film.

\subsubsection{Titanium-Alloy Corrosion Coupons}

Titanium-55A CC corrosion coupons from experiments EE and L-4-12, Ti-55A LC coupons from experiment $\mathrm{EE}$, and $\mathrm{Ti}-55 \mathrm{~A}$ and $\mathrm{Ti}-3 \% \mathrm{Al}$ coupons from $\mathrm{CA}$ and $\mathrm{LA}$ positions of experiment $\mathrm{L}-4-18$ were examined. In addition, the two Ti-55A LC coupons which were loose in their holder upon completion of the experiment L-4-12 were examined. All coupons appeared smooth, with no evidence of corrosive attack.

\subsubsection{Stress-Corrosion Specimen s}

Metallographic examination of the stress-corrosion specimens from loop EE revealed no tendency for localized or accelerated corrosive attack with respect to the stress or flux pattern. All stainless steel stress specimens showed light pitting attack very similar to that noted on the corrosion coupons. Stress specimens fabricated of Zircaloy-2 exhibited an extremely rough, uneven surface. However, since the roughness of the original specimen surfaces is unknown (specimens were sandblasted), it is impossible to determine what portion of this roughness is due to corrosive attack. No evidence of corrosive attack was noted in the examination of the titanium stress-corrosion specimens.

From metallographic examination of the L-4-12 stress-corrosion specimens it was apparent that there was a definite couple attack between the 17-4 PH stainless steel specimen SH-1 and the C-130 AM titanium alloy specimen TE-1. It also appears that the $6 \% \mathrm{Al}-4 \% \mathrm{~V}-\mathrm{Ti}$ alloy was somewhat more susceptible to attack in the pressurizer than the C-130 AM titanium alloy. Specimens of $6 \% \mathrm{Al}-4 \% \mathrm{~V}-\mathrm{Ti}$ exposed in the in-line and core regions of this experiment showed scattered shallow cracks. The cracking was of such a nature that stress corrosion may or may not be indicated. A typical cross section containing these cracks is shown in Fig. 61.

Core and in-line stress specimens of Zircaloy-2 contained in loop L-4-18 were smooth and even, with no evidence of pitting or cracking.

\subsubsection{Loop Components}

The interior surface of the type 347 stainless steel core cap from loop GG appeared very rough and uneven, with evidence of intergranular attack to a depth of approximately 1 mil (Fig. 62). The other stainless steel caps exhibited varying degrees of roughness and corrosion penetration but no intergranular attack. No evidence of corrosive attack was noted on the titanium cap employed in loop L-4-12. 


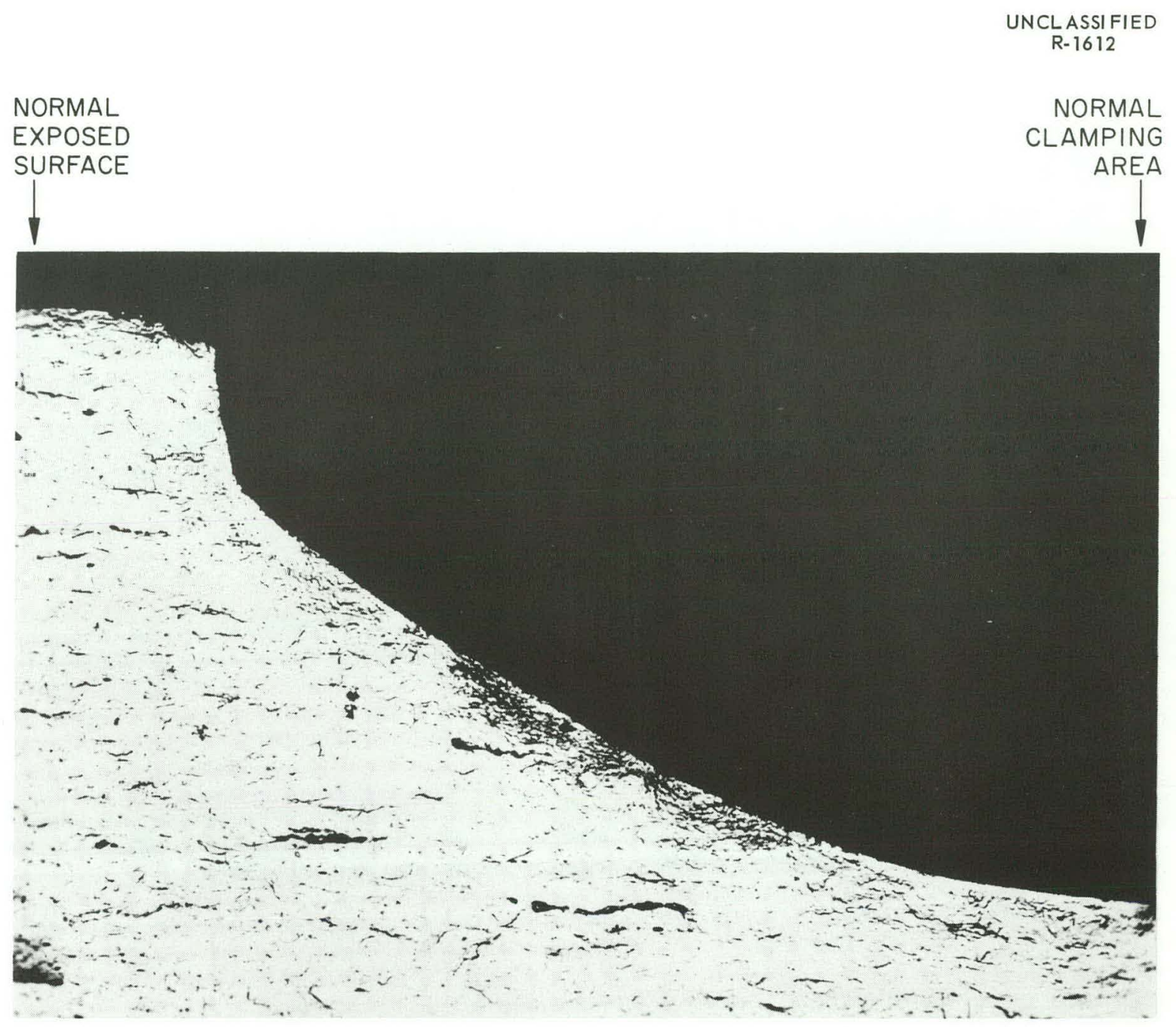

Fig. 59. End of Damaged Zircaloy-2 LC Coupon, Loop L-4-12. 250 X.

The cause of the large pit (Fig. 63) in the weld in the reducer section of the stainless steel core in loop FF is unknown but is probably the result of a bad weld.

Several cracks about 5 mils long appeared to emanate from the inner core surface at the core body-toreducer weld in the Ti-75A core from loop L-4-12. One of these cracks is shown in Fig. 64. Subsequent examination of this area indicated that the inner surface was contaminated by oxygen. ${ }^{25}$ This was confirmed by a microhardness traverse of the area, which showed the hardness to range from approximately $558 \mathrm{DPH}$ at the inner surface to about $200 \mathrm{DPH}$ at a depth of 40 mils. From this depth the hardness remained near $200 \mathrm{DPH}$ through the remainder of the weld and adjacent base metal.

\footnotetext{
${ }^{25}$ M. L. Picklesimer, Metallographic Examination of Titanium Core Weld from In-Pile Loop L-4-12, in press.
} 
UNCL ASSIFIED

R- 1693
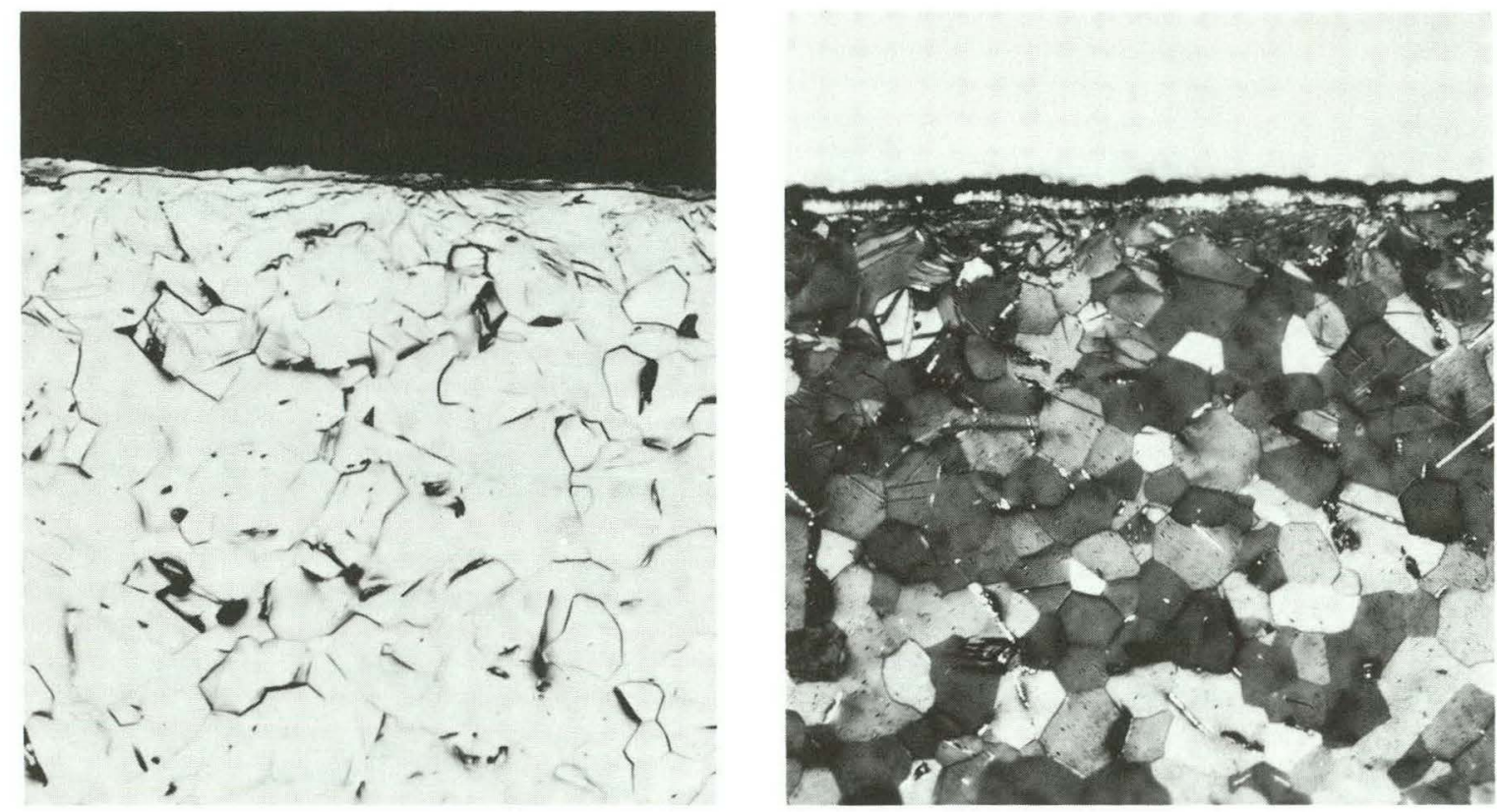

Fig. 60. Scale on Crystal-Bar Zir conium LC Coupon Z-115, Loop L-4-13. 250 X.

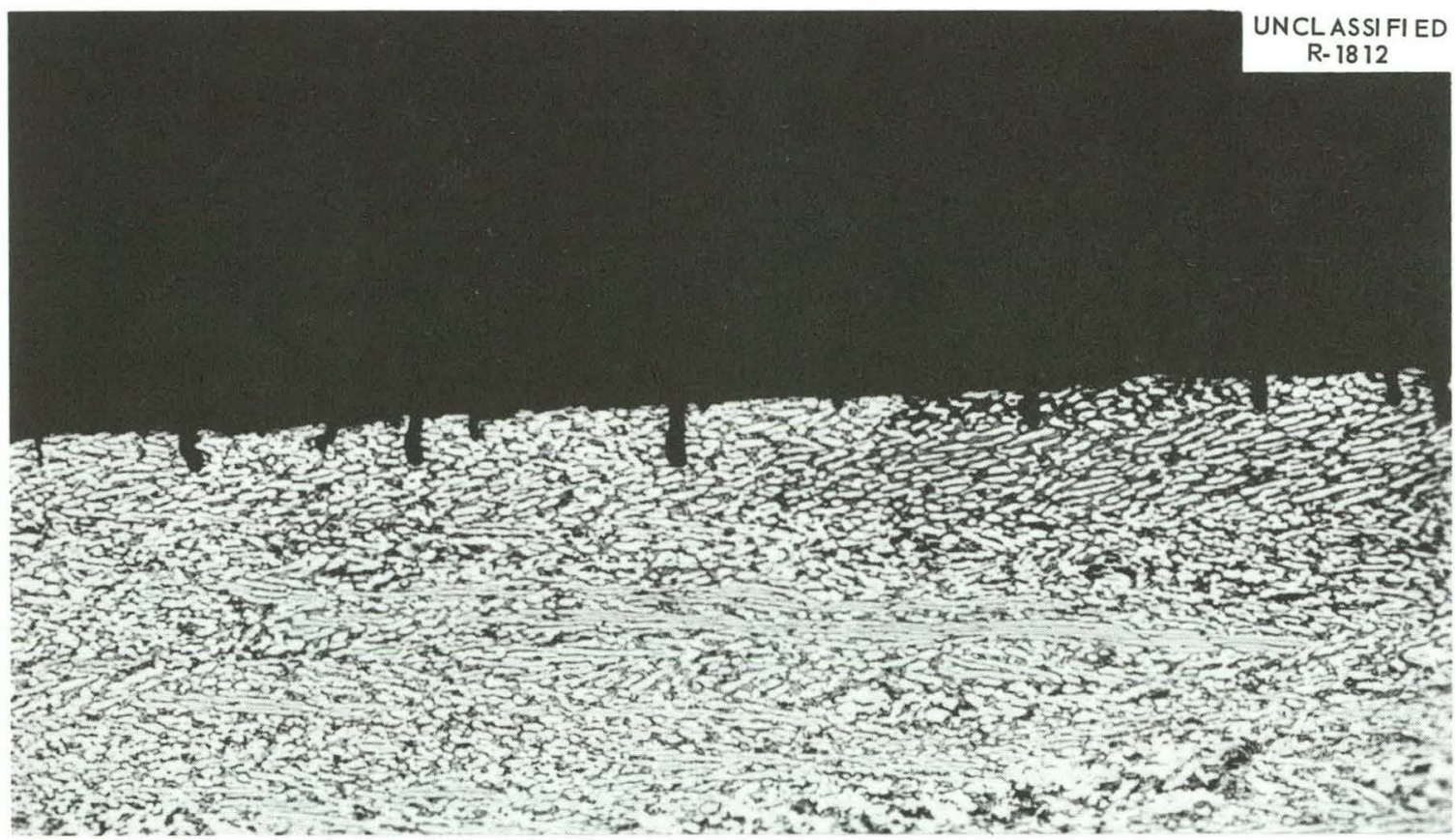

Fig. 61. Tension Surface of Titanium Specimen TJ-12 from Core, Loop L-4-12. 250 X. 


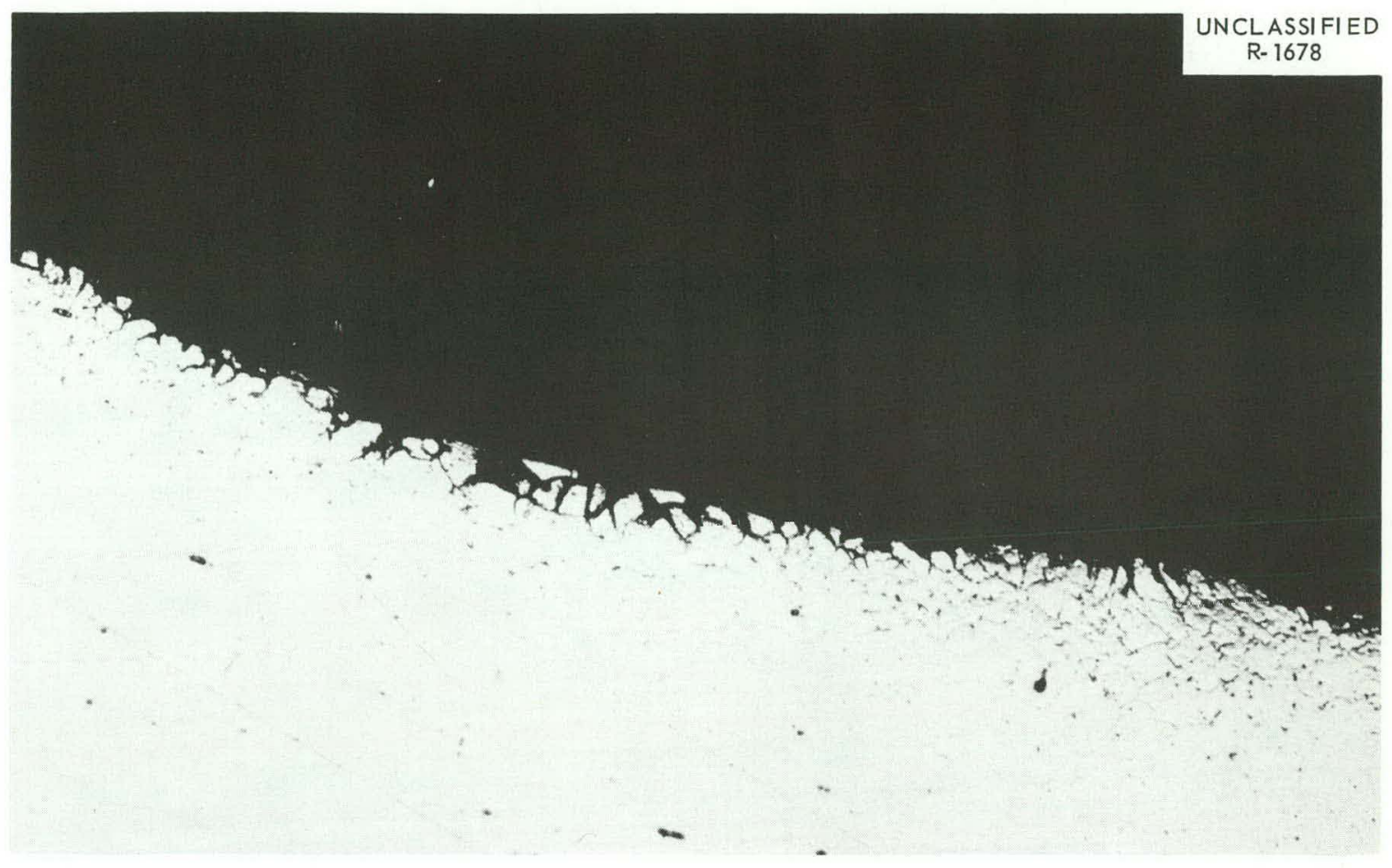

Fig. 62. Type 347 Stainless Steel Core Cap, Loop GG. 250 X.

Sections from the inlet and outlet ends (exposed to liquid or vapor during operation) of the type 347 stainless steel pressurizers from all of the loops exhibited, in most cases, rough surfaces and some attack at the grain boundaries. A photomicrograph of a liquid-region section from loop DD is shown in Fig. 65.

Sections from the type 347 stainless steel pressurizer heater lines (loop L-4-18) exhibited a thin oxide film formation, with slight (less than $\frac{1}{4} \mathrm{mil}$ ) corrosive penetration at the grain boundaries. Similar sections from the other loops as well as sections of pipe from the pump outlets and pressurizer thermocouple wells showed no evidence of corrosive attack.

An unusual occurrence of corrosion was observed on one of the clamping bands of the core coupon holder from loop EE. The band, located at the core outlet end of the holder, exhibited an isolated area of attack (Fig. 66).

Intergranular attack to a depth of 5 mils was observed in a section of the sampler-line capillary tubing from loop L-4-18. A portion of the area of attack is shown in Fig. 67.

\subsubsection{X-Ray Examination of Specimens and Scales}

Examinations were made ${ }^{26}$ of standard Zircaloy-2, titanium, and stainless steel coupons and in-pile loop samples, bulk oxides, loop scale, and films by using the shielded $\mathrm{x}$-ray diffractometer.

${ }^{26}$ G. E. Klein, letter to A. R. Olsen, "X-Ray Examination of Zircaloy-2, Titanium, and Stainless Steel HRP InPile Loop Specimens and Products Therefrom," Sept. 13, 1955. 


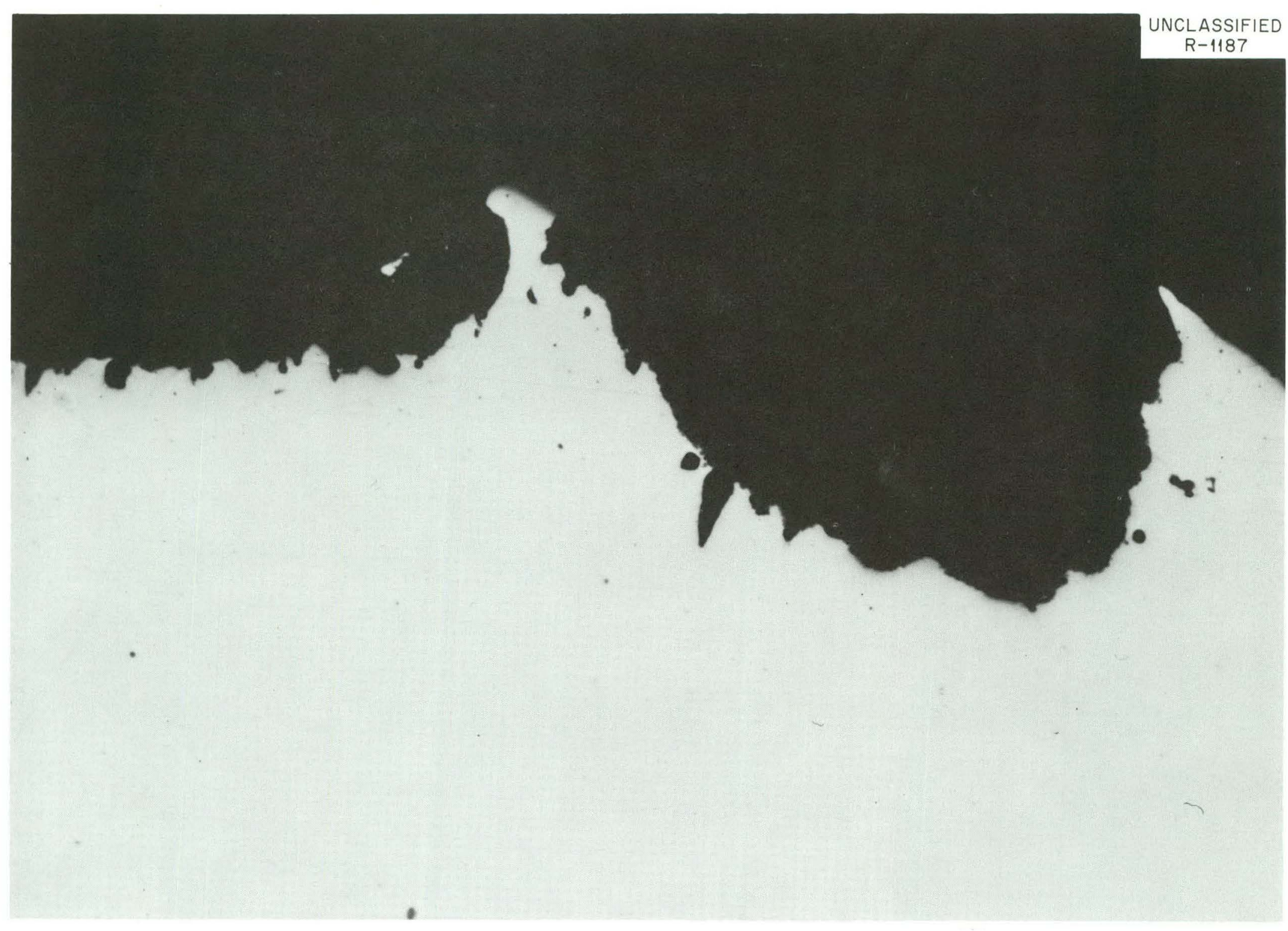

Fig. 63. Pit Area in Core Weld, Loop FF. 250 X. 


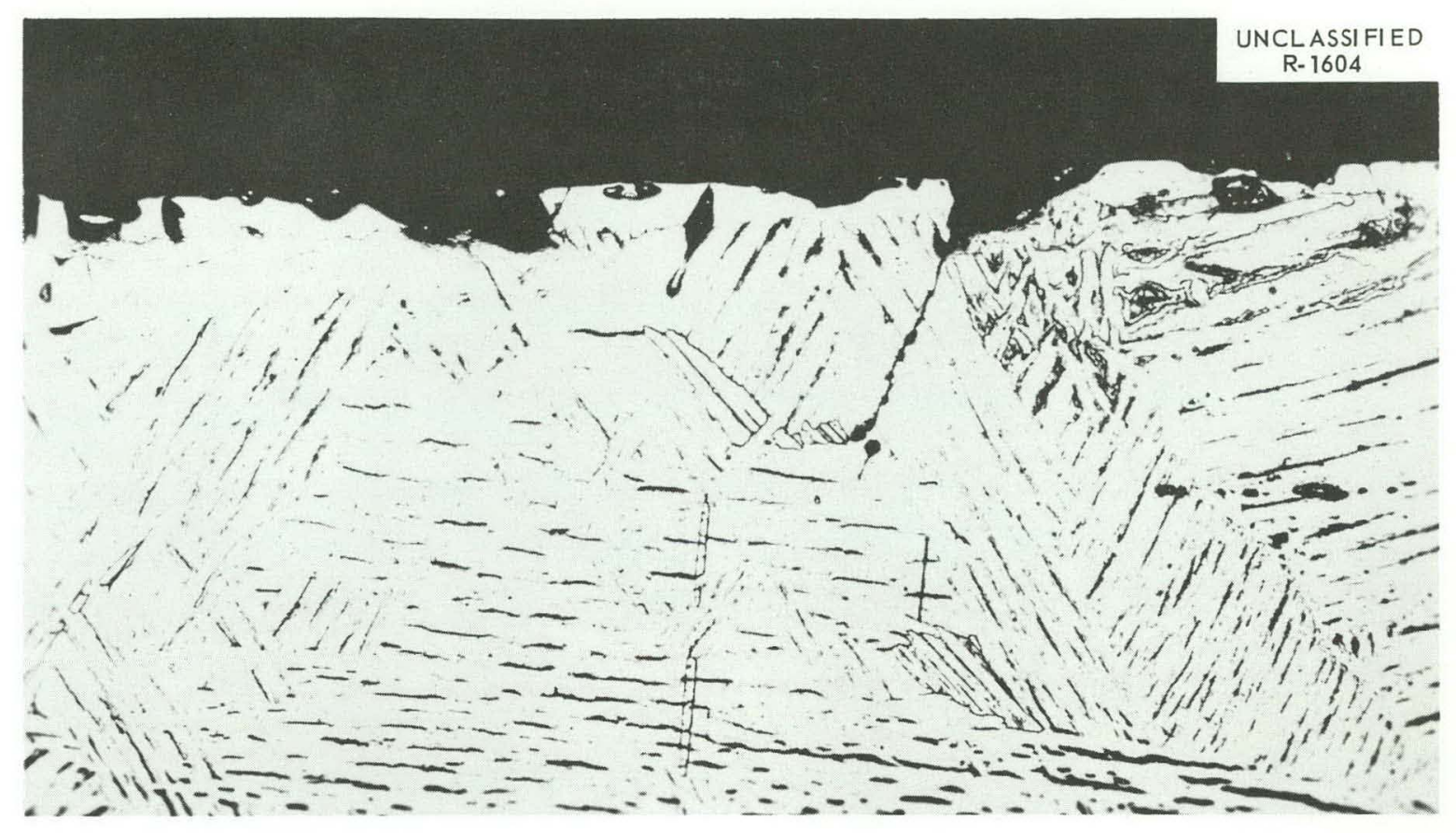

Fig. 64. Weld of Titanium-75A Core Body to Reducer, Loop L-4-12. 250 X。

All solid coupons gave an $x$-ray pattern of the base composition, that is, a-zirconium, titanium, or stainless steel if the covering film was stripped off. No base-metal diffraction occurred with coupons from which the scale was not removed. At the same time the scale itself showed no recorded crystallinity. Some few stripped coupons from experiment GG, namely $945 \mathrm{~A}$, LC position K, and $941 \mathrm{~A}$, LC position G, also showed the presence of the strongest lines of the monoclinic form of $\mathrm{ZrO}_{2}$.

Both bulk oxides and stripped films revealed no $x$-ray structure, with the exception of the films stripped from experiment L-4-12 Zircaloy-2 CC coupon Z-92, which showed the presence of $\alpha$-zirconium.

Klein concluded that the in situ scale appeared to be noncrystalline, and no reflection was obtained from the base metal. The stripped films were too thin, for the most part, to diffract properly for obtaining an $\mathrm{x}$-ray pattern.

Results of these examinations are summarized in Table 33.

\subsection{Results of Fission-Power Determinations}

\subsubsection{Induced Activities}

Thermal-neutron fluxes determined from results of induced-activity measurements in each of the several experiments are illustrated in Fig. 68, where the logarithm of the flux is plotted vs the axial position in the loop core. The actual data points for four of the different experiments are plotted in Figs. 69-72. The fission-power density in solution adjacent to a specimen was computed from the flux value indicated by the plot in Fig. 68, together with values of 580 barns and $200 \mathrm{Mev} /$ fission for the fission cross section 


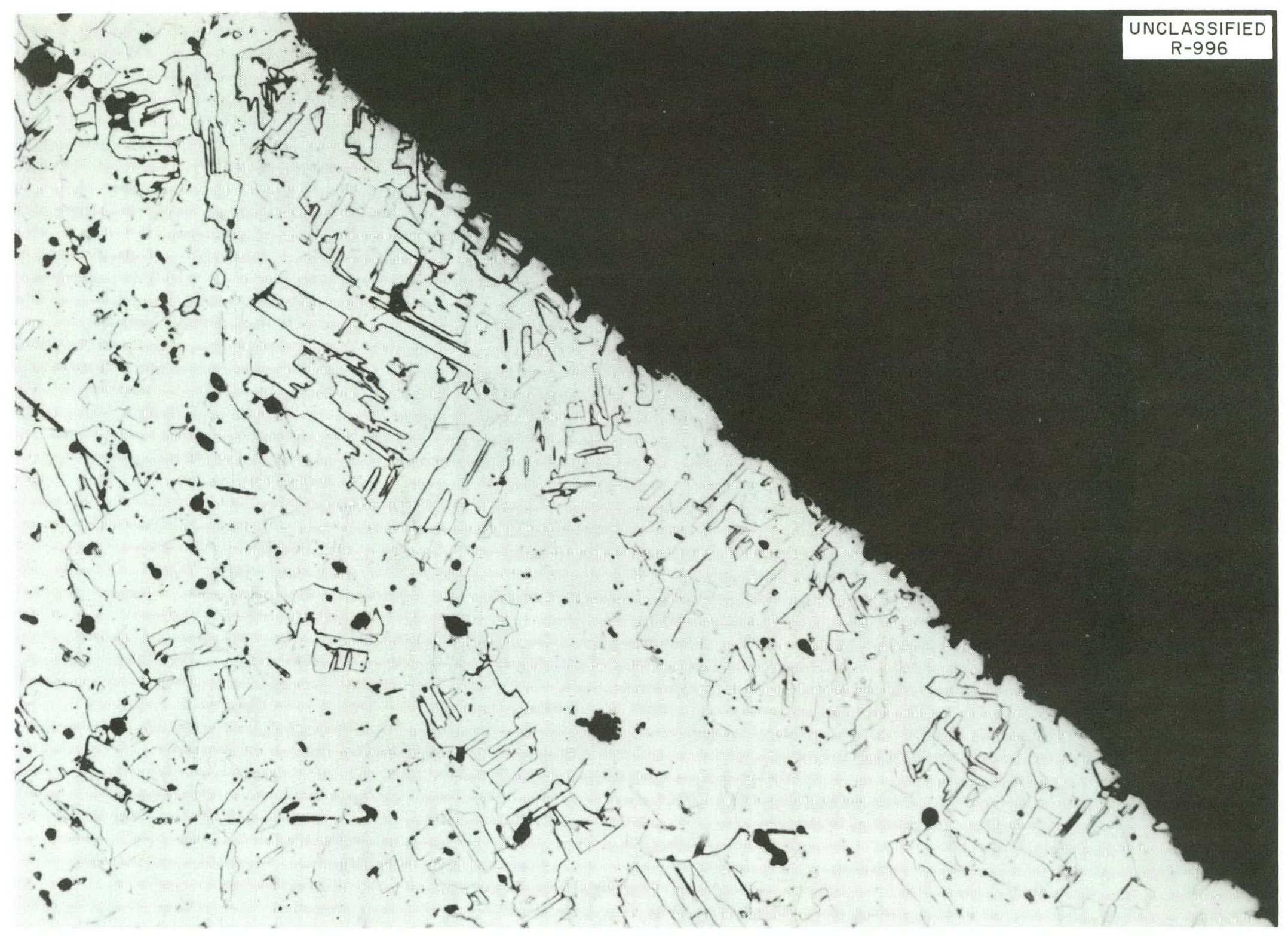

Fig. 65. Type 347 Stainless Steel Pressurizer, Loop DD. 250 X. 


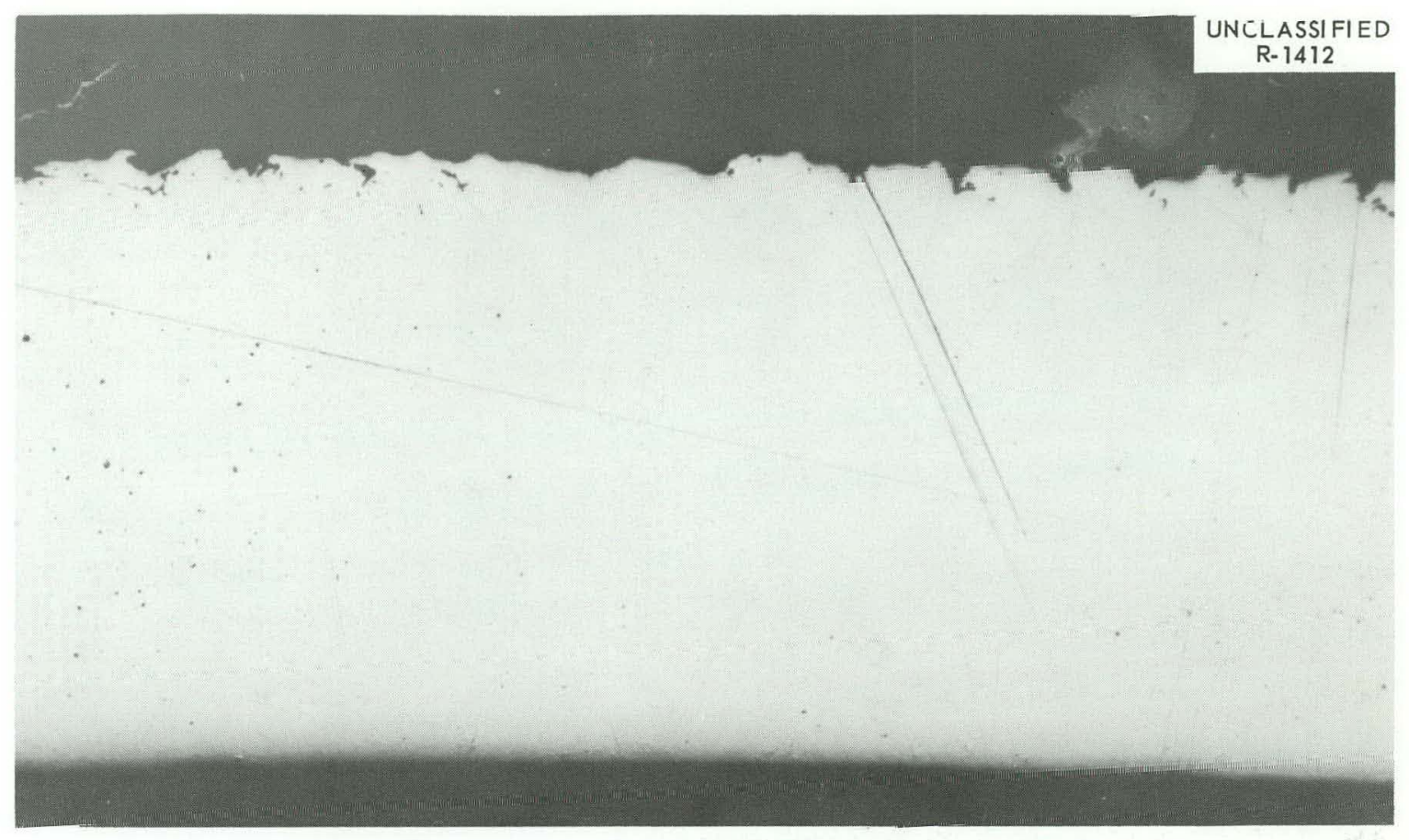

Fig. 66. Core Coupon Holder Clamping Band, Loop EE.

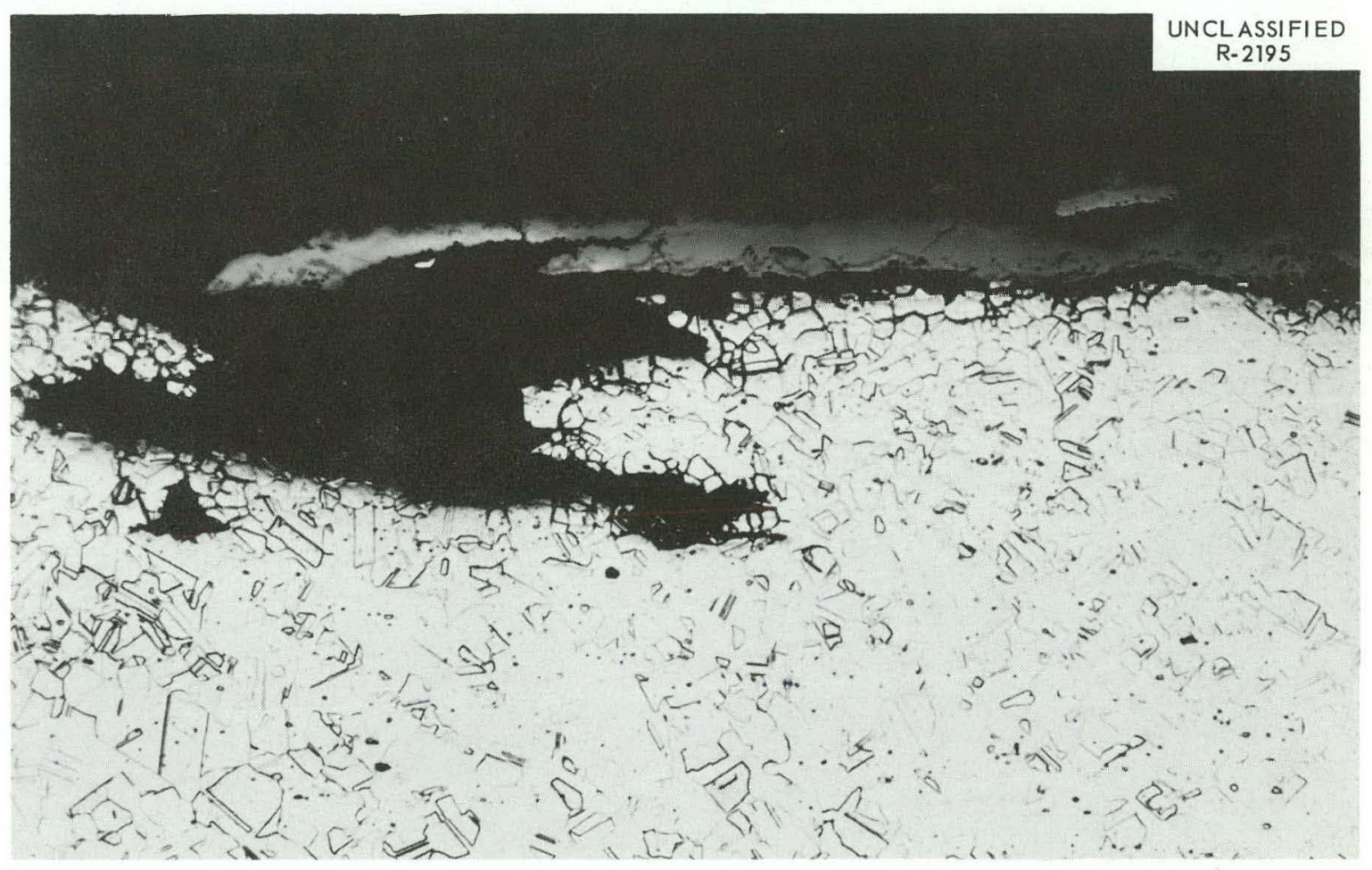

Fig. 67. Sampler-Line Capillary Tubing, Loop L-4-18. 250 X. 
Table 33. Summary of X-Ray Examination of Specimens and Scales

\begin{tabular}{|c|c|c|c|c|c|c|c|}
\hline Experiment & $\begin{array}{l}\text { Sample } \\
\text { Number }\end{array}$ & Material & Location & $\begin{array}{l}\text { Power } \\
\text { Density } \\
(\mathrm{w} / \mathrm{ml})\end{array}$ & $\begin{array}{c}\text { Solution } \\
\text { Velocity } \\
\text { (fps) }\end{array}$ & Sample Condition & $\mathrm{X}$-Ray Identification \\
\hline None & & Ti-75A & & & & Coupon as machined & Titanium \\
\hline None & & Zircaloy-2 & & & & Coupon as machined & $\alpha-Z$ irconium \\
\hline None & & $347 \mathrm{SS}$ & & & & Coupon as machined & Stainless Steel \\
\hline \multirow[t]{6}{*}{ GG } & $S-1$ & Scale & & & & Scale from core holder & Unidentified pattern \\
\hline & $948 \mathrm{~A}$ & Zircaloy-2 & Core channel & 4.5 & 13 & Stripped coupon & $\alpha$-Zirconium \\
\hline & $953 \mathrm{~A}$ & Zircaloy-2 & Core channel & 2.5 & 46 & Stripped coupon & $\alpha-Z$ irconium \\
\hline & $957 \mathrm{~A}$ & Zircaloy-2 & Core channel & 1.5 & 17 & Stripped coupon & $\alpha-Z$ irconium \\
\hline & $941 \mathrm{~A}$ & Zircaloy-2 & In-line channel & & 46 & Stripped coupon & $a-\mathrm{Zirconium}+\mathrm{ZrO}_{2}$ \\
\hline & $945 \mathrm{~A}$ & Zircaloy-2 & In-line channel & & 17 & Stripped coupon & $a-\mathrm{Zirconium}+\mathrm{ZrO}_{2}$ \\
\hline \multirow[t]{5}{*}{ EE } & $743 \mathrm{~A}$ & $347 \mathrm{SS}$ & Core channel & 4.6 & 12 & Stripped coupon & Stainless steel \\
\hline & $743 \mathrm{~A}$ & Film & Core channel & 4.6 & 12 & Stripped from coupon $743 \mathrm{~A}$ & No pattern \\
\hline & $747 \mathrm{~A}$ & 347 SS & Core channel & 2.3 & 39 & Stripped coupon & No pattern \\
\hline & $787 \mathrm{~A}$ & 347 SS & Core channel & 1.0 & 10 & Stripped coupon & Stainless Steel \\
\hline & $787 \mathrm{~A}$ & Film & Core channel & 1.0 & 10 & Stripped from coupon $787 \mathrm{~A}$ & No pattern \\
\hline
\end{tabular}




\begin{tabular}{|c|c|c|c|c|c|c|c|}
\hline & $740 \mathrm{~A}$ & $347 \mathrm{SS}$ & In-line channel & & 39 & As-removed coupon & No pattern \\
\hline \multirow{6}{*}{ ' } & $736 \mathrm{~A}$ & Film & In-line channel & & 12 & Stripped from coupon $736 A$ & No pattern \\
\hline & $\mathrm{T}-8$ & $\mathrm{Ti}-75 \mathrm{~A}$ & Core channel & 5.7 & 9 & Stripped coupon & Titanium \\
\hline & $T-9$ & Ti-75A & Core channel & 3.9 & 14 & As-removed coupon & No pattern \\
\hline & $I-9$ & Film & Core channel & 3.9 & 14 & Stripped from coupon $T-9$ & No pattern \\
\hline & $\mathrm{T}-12$ & $T_{i}-75 A$ & Core channel & 2.5 & 36 & Stripped coupon & Titanium \\
\hline & $T-16$ & Ti-75A & Core channel & 1.2 & 13 & Stripfed coupon & Titanium \\
\hline & $T-16$ & $\mathrm{Ti}-75 \mathrm{~A}$ & Core channel & 1.2 & 13 & Stripfed from coupon T-16 & No pattern \\
\hline & $T-0$ & Film & Core channel & & 9 & Stripped from coupon T-0 & No pattern \\
\hline & Z-19 & Zircaloy -2 & Core channel & 5.3 & 10 & Stripped coupon & $\alpha-Z$ irconium \\
\hline & $Z-20$ & Film & Core channel & 4.5 & 11 . & Stripped coupon Z-20 & No pattern \\
\hline & $Z-24$ & Zircaloy -2 & Core channel & 2.7 & 34 & Stripped coupon & $\alpha$-Zirconium \\
\hline & $Z-37$ & Zircaloy-2 & Core channel & 1.3 & 12 & Stripped coupon & a-Zirconium \\
\hline & $Z-37$ & Film & Core channel & 1.3 & 12 & Stripped from coupon Z-37 & No pattern \\
\hline & $\mathrm{Z}-12$ & Zircaloy -2 & In-line channel & & 34 & As-removed coupon & No pattern \\
\hline & $\mathrm{Z}-1$ & Film & In-line channe] & & 10 & Stripped from coupon Z-1 & No pattern \\
\hline \multirow[t]{6}{*}{$L-4-12$} & $\mathrm{Z}-88$ & Zircaloy -2 & Core channel & 4.6 & 10 & Stripped coupon & $a-Z i r c o n i u m$ \\
\hline & $\mathrm{Z}-88$ & Film & Core channel & 4.6 & 10 & Stripped from coupon Z-88 & No pattern \\
\hline & $\mathrm{Z}-89$ & Zircaloy -2 & Core channel & 4.2 & 11 & As-removed coupon & No pattern \\
\hline & $\mathrm{Z}-92$ & Zircaloy -2 & Core channel & 1.9 & $4 \dot{4}$ & Stripped coupon & $\alpha-Z i r c o n i u m$ \\
\hline & $Z-92$ & Film & Core channel & 1.9 & 44 & Stripped from coupon Z-92 & $a-Z i r c o n i u m$ \\
\hline & $Z-94$ & Zircaloy-2 & Core channel & 1.2 & 15 & As-removed coupon & No pattern \\
\hline
\end{tabular}




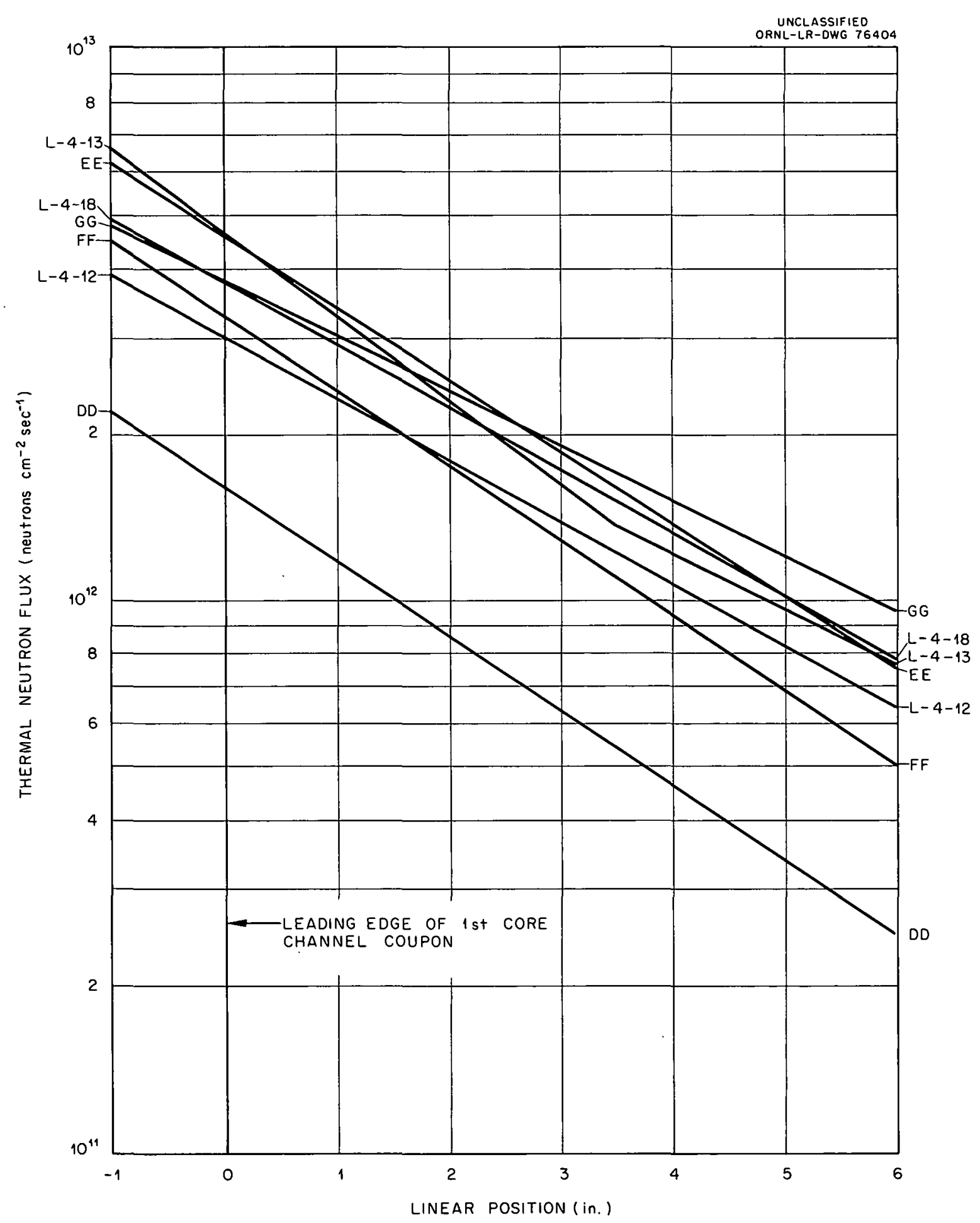

Fig. 68. Thermal Neutron Flux in Core vs Linear Position. 


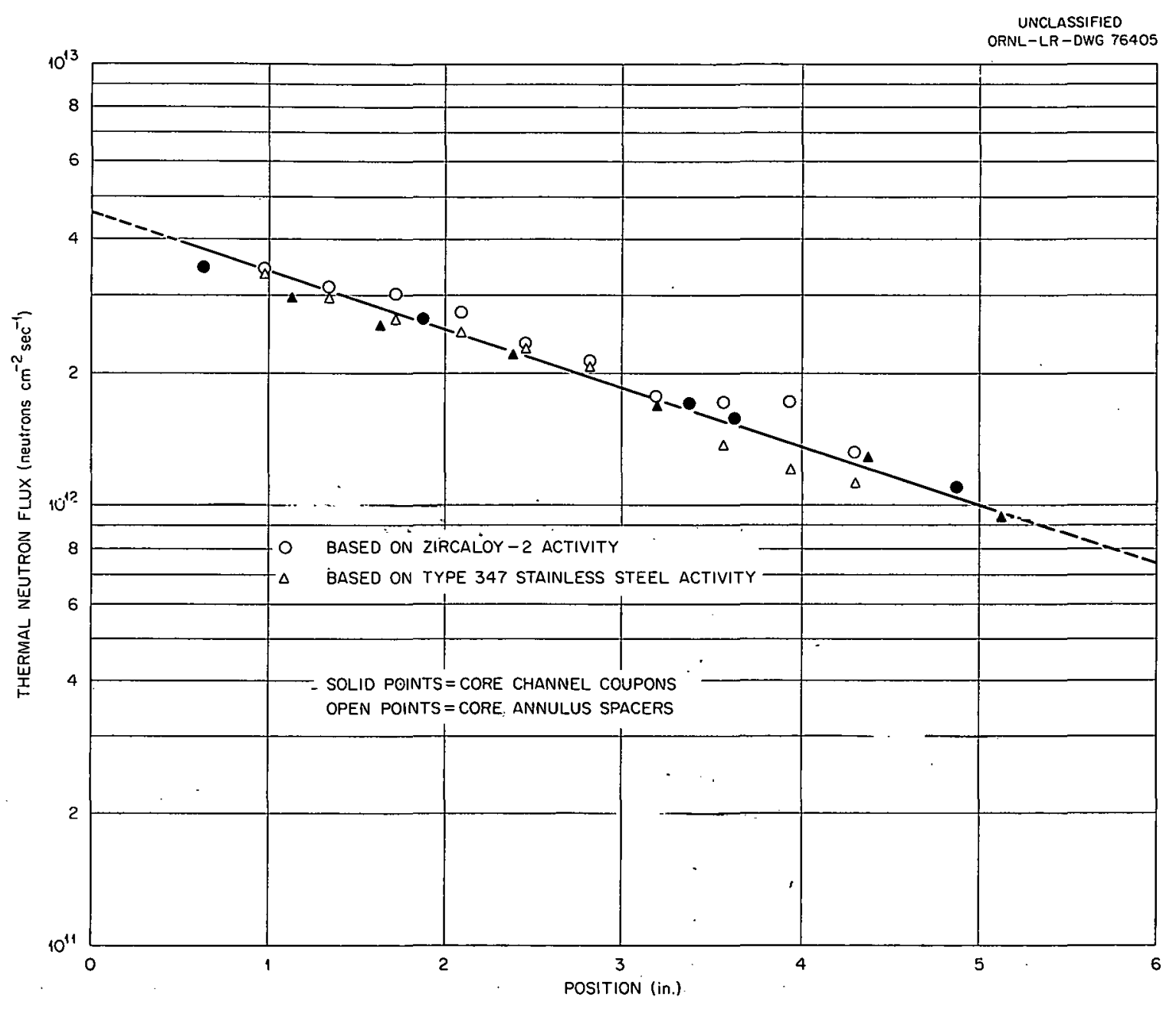

Fig. 69. Neutron Fluxes from Induced Activity Meosurements, Loop EE.

and energy respectively. The calculated fission power near each specimen is set forth in the weight data, Tables 36-42.

\subsubsection{Cesium $\cdot 137$}

The results of $\mathrm{Cs}^{137}$ analyses are shown in Fig. 73 in terms of the average fission powers in a loop at an LITR power of $3 \mathrm{Mw}$ calculated from the analytical results and the reactor energy accumulated during the total exposure preceding the time of sampling. A further illustration of the $\mathrm{Cs}^{137}$ data is shown in Fig. 74, where the L-4-13 data are plotted in terms of the average fission powers in the loop during the periods between adjacent samples as indicated by the difference between the $\mathrm{Cs}^{137}$ content of the samples.

As may be judged from the plots, the analytical data scattered appreciably. Within the indicated uncertainty there is no evidence that the actual fission rate or uranium concentration in the loop core changed 


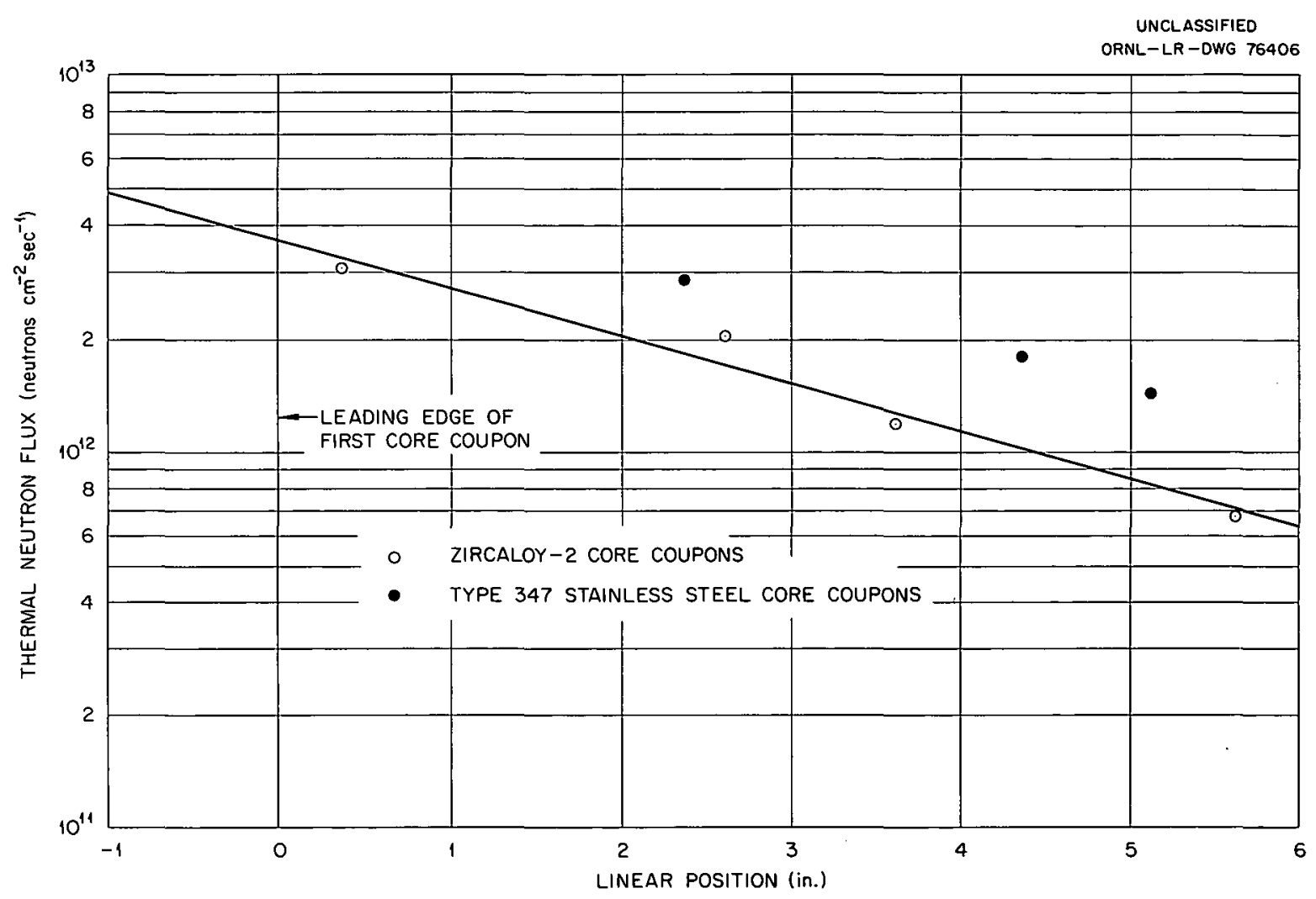

Fig. 70. Neutron Fluxes from Induced Activity Measurements, Loop L-4-12.

significantly during any of the experiments. The L-4-12 results for the second solution charge probably reflect some carry-over of $\mathrm{Cs}^{137}$ produced in the original solution charge.

\subsubsection{Comparison of Average Fission-Power Values from $\mathrm{Cs}^{139}$ and from Induced Activities}

Values for the cumulative average fission power in a loop experiment at $3 \mathrm{Mw}$ LITR pow er calculated from the $\mathrm{Cs}^{137}$ and from induced-activity results are compared in Table 34 . The average of the $\mathrm{Cs}^{137}$ re* sults in each experiment is the final point shown in Fig. 73. The induced-activity calculations employed the neutron fluxes shown in Fig. 68 and the average uranium concentrations listed in Table 34 . A value of $200 \mathrm{Mev} / \mathrm{fission}$ was assumed throughout.

In general, there is poor agreement between the $\mathrm{Cs}^{137}$ and the induced-activity values. The cesium values are the lowest values in all the experiments, except in loop DD. Other workers ${ }^{27}$ have found that fission values determined from $\mathrm{Cs}^{137}$ analyses tend to be lower by about $15 \%$ than those determined from other, more standard methods. Although no completely satisfactory explanation of these differences has

${ }^{27}$ R. G. Hart, M. Lounsbury, and C. D. McKay, A Comparison of Metbods of Determining Burnup in Uranium Dioxide Fuel Test Specimens. Part 1. Studies on a Single Stringer Fuel Charge (Nuclear Reactor Chemistry - First Conference, Gatlinburg, Tennessee - Oct. 12-14, 1960), TID-7610. 


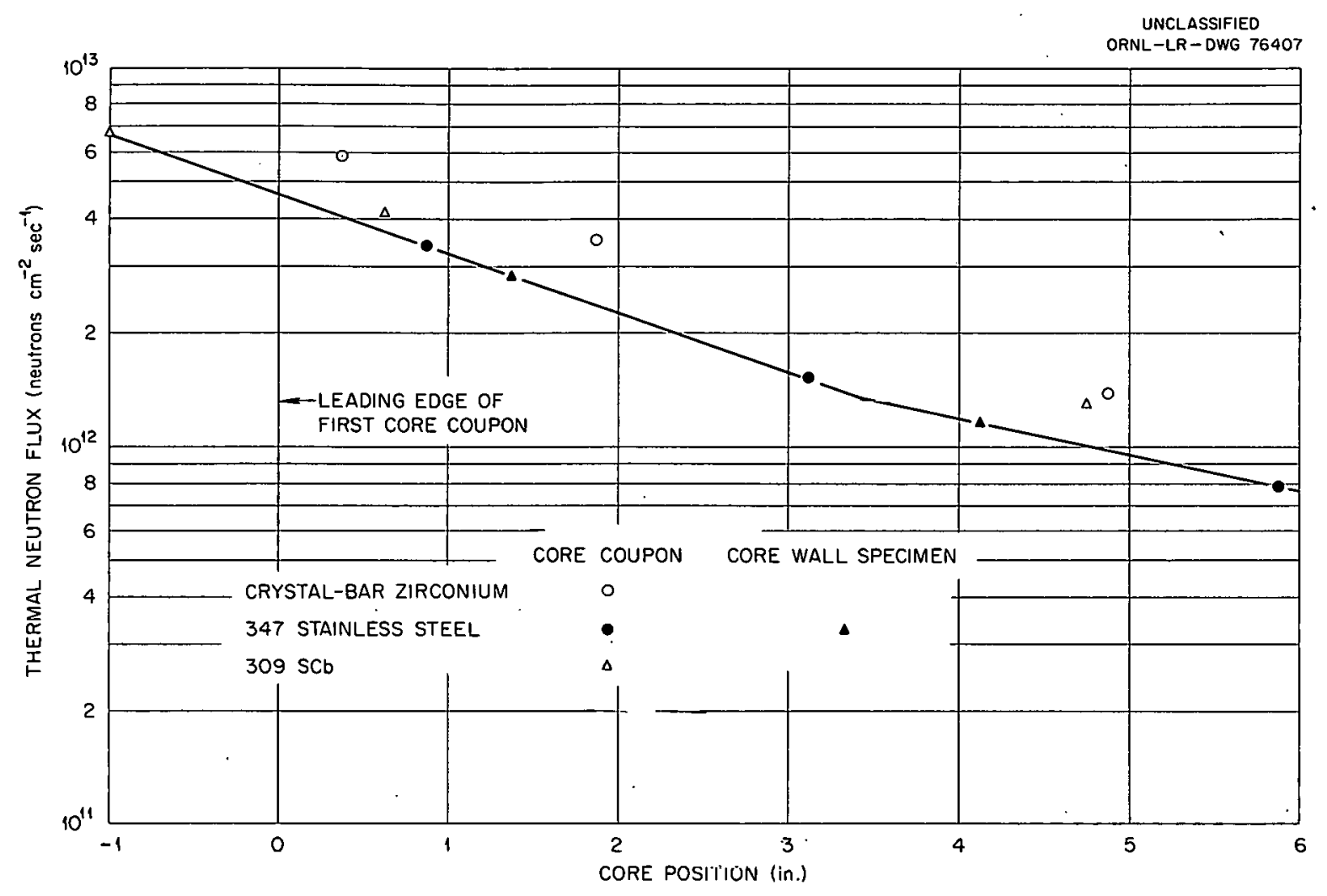

Fig. 71. Neutron Fluxes from Induced Activity Meosurements, Loop L-4-13.

been evolved, the experimental $\mathrm{Cs}^{137}$ data for total fission power for the experiments reported here are considered more reliable than those calculated from specimen activities. In part, this belief is based on results obtained in later in-pile loop experiments which show that fission-power values determined from fission- and gamma-heat measurements were in better agreement with the power values indicated by $\mathrm{Cs}^{137}$ measurements than with those obtained from specimen activity data. The following factors are believed to contribute to the differences between fission powers evaluated from induced activities and cesium.

1. A value of 36.5 barns was taken for the Co ${ }^{59}$ cross section in preparing specimens for the inducedactivity measurements. ${ }^{28}$ The effective cross section of $\mathrm{Co}^{59}$ at the location of the standards may have been up to 10 to $15 \%$ greater than this, depending upon the flux of resonance-energy neutrons, so that the thermal flux at the loop specimens may have been up to 10 to $15 \%$ less than calculated.

2. No corrosion specimens were located in approximately the first inch of the core (core nose), and thermal-neutron flux values in this region were obtained from extrapolation of values from induced-activity measurements of specimens located farther to the rear.in the core body. Also, the precise locations of these specimens, with respect to the core nose, were not known.

${ }^{28}$ F. J. Johnston, J. Halperin, and R. W. Stoughton, J. Nucl. En ergy, PL. A 11, 95 (1960). 


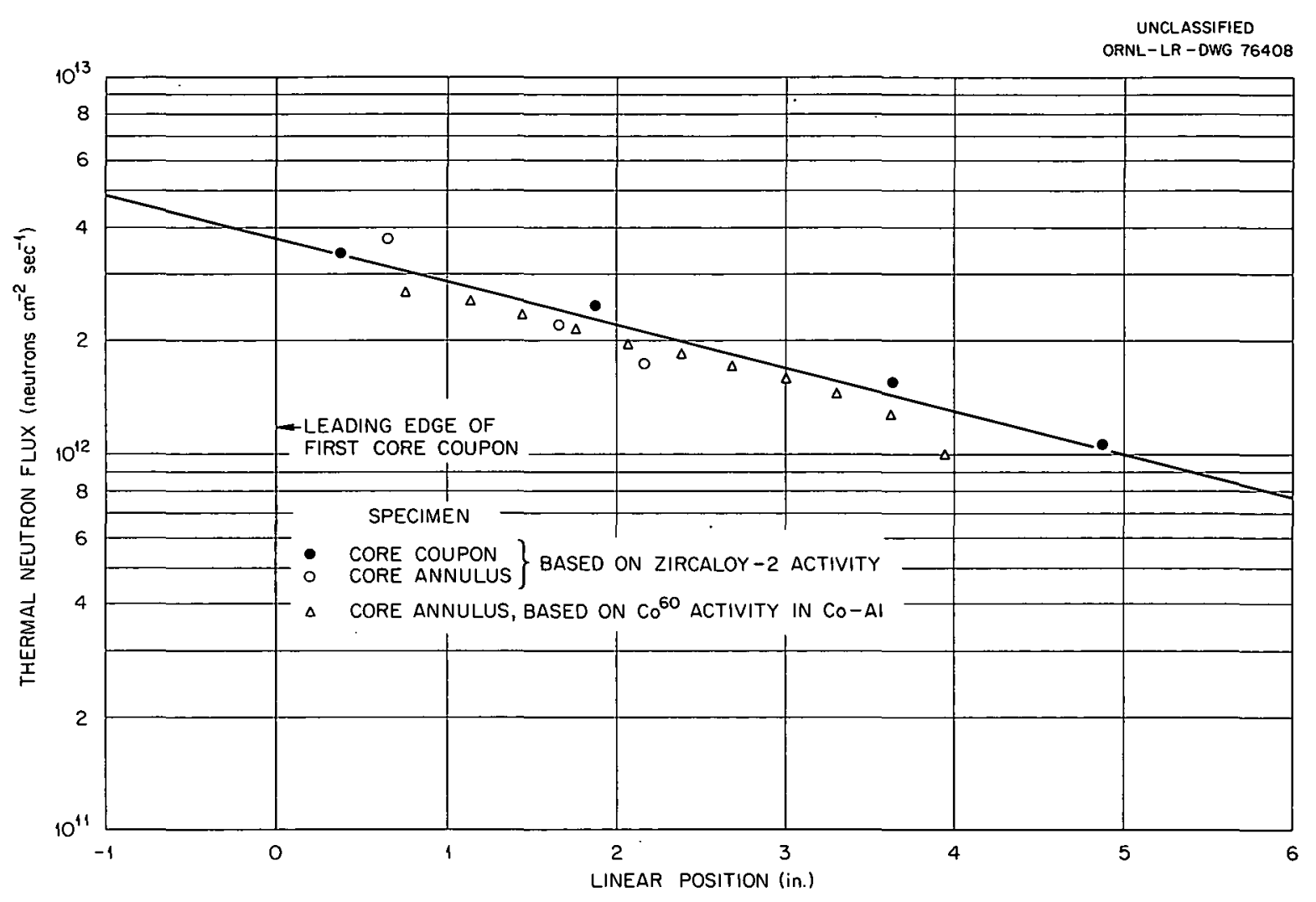

Fig. 72. Neutron Fluxes from Induced Activity Meosurements, Loop L-4-18.

3. Some fission product cesium may have been sorbed on corrosion scales in the loops; however, where scales have been analyzed for $C s^{137}$ (Table 35, loop L-4-18 and in later experiments ${ }^{29}$ ), the results indicate negligible sorption. Hence it is considered likely that the sorption was negligible in the experiments under discussion.

\subsection{Results of Quantitative Examination of Loops}

\subsubsection{Analyses of Scale from Low-Power-Density Regions}

An attempt was made to determine the distribution of corrosion products, uranium, and $C s^{137}$ throughout the L-4-18 loop system by chemical analyses of samples of bulk scale removed from surfaces in various portions of the loop. The analytical results are listed in Table 35.

The results for different samples show considerable differences in composition for most of the elements, and thus the three samples cannot be considered representative of all scale in the loop. Qualitatively, the results support conclusions drawn from scale analyses in subsequent experiments at higher

${ }^{29}$ G. H. Jenks et al., HRP Quart. Progr. Rept. Oct. 31, 1958, ORNL-2654, P 154. 


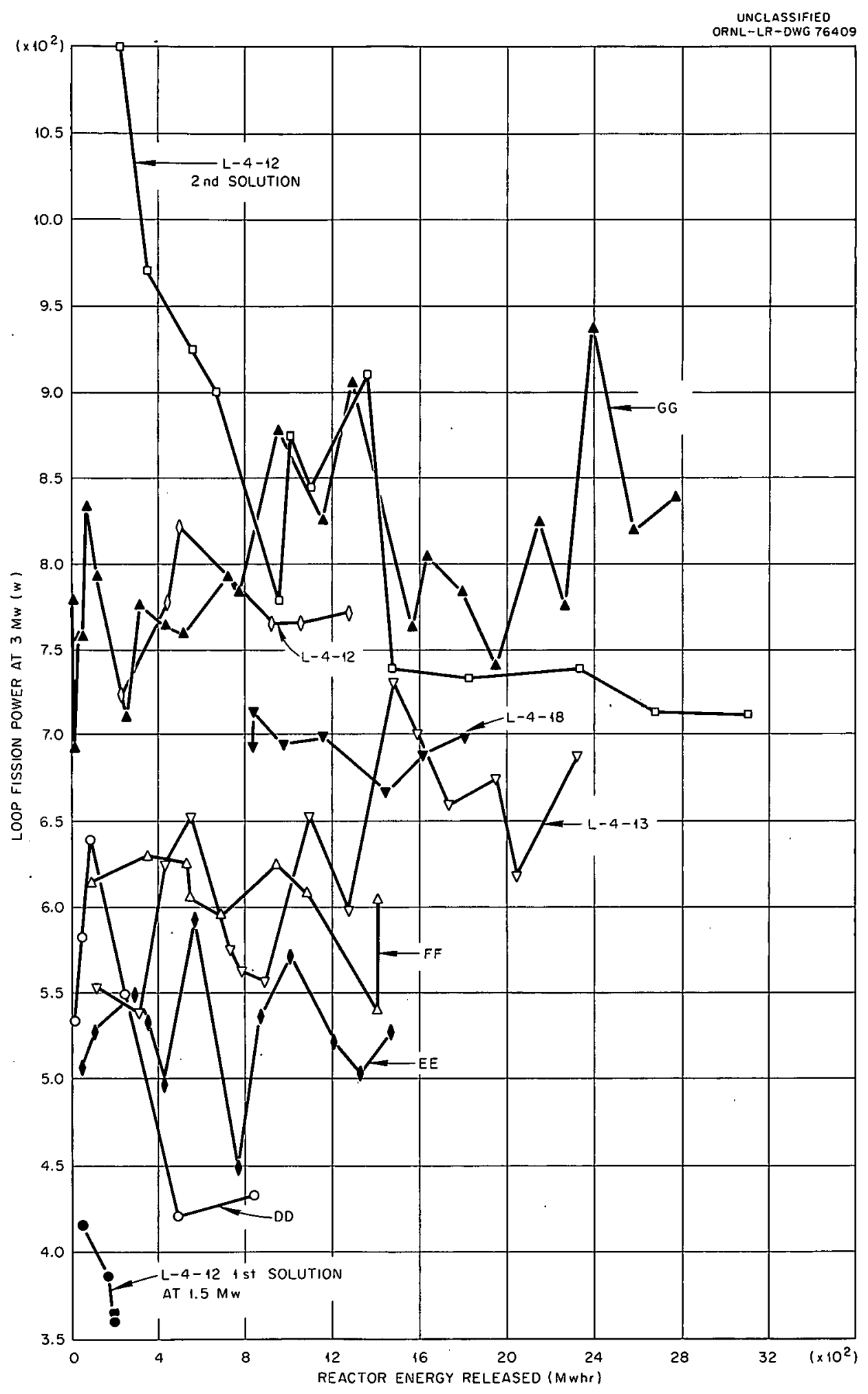

Fig. 73. Cumulative Average Fission Power of $3 \mathrm{Mw}$ Based on $\mathrm{Cs}^{137}$ Analyses. 


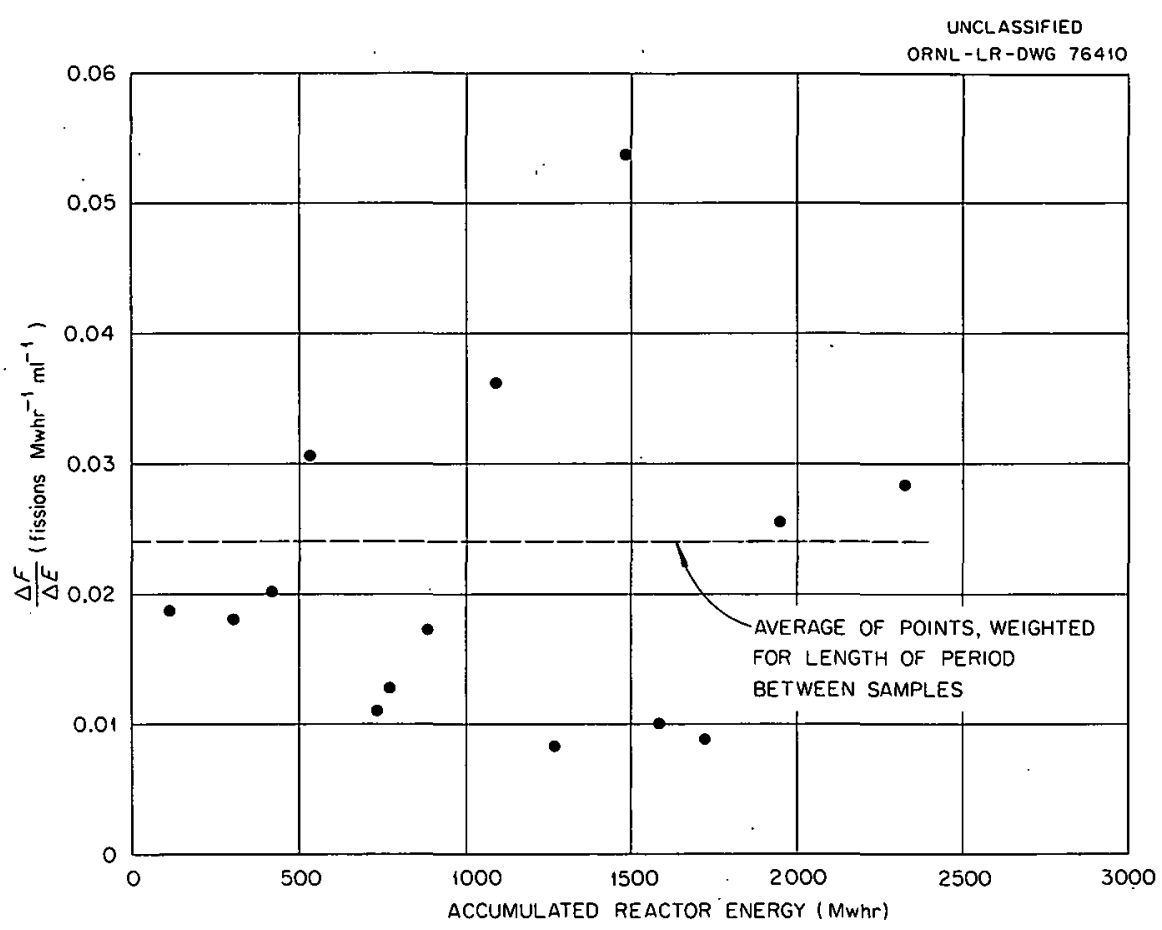

Fig. 74. $\frac{\text { Increase in } C s{ }^{137} \text { During Periods Between Adjacent Samples, } \Delta F}{\text { Increase in LITR Energy Between Adjacent Samples, } \Delta E}$ vs LITR Energy Accumulated During Exposure of Loop L-4-13.

Table 34. Average Fission Power in Loop Experiments of 3 Mw LITR Power ${ }^{a}$ as Determined from $\mathrm{Cs}_{s}{ }^{137}$ and Specimen. Activity Analyses

\begin{tabular}{lcccc}
\hline Loop & $\begin{array}{c}\mathrm{Cs}^{137} \text { Value } \\
(\mathrm{w})\end{array}$ & $\begin{array}{c}\text { Specimen Activity } \\
\text { Value } \\
(\mathrm{w})\end{array}$ & $\begin{array}{c}\text { Specimen Activity } \\
\mathrm{Cs}\end{array}$ & $\begin{array}{c}\text { Calculated Average } \\
\text { Concentration of Uranium } \\
(\mathrm{mg} / \mathrm{ml})\end{array}$ \\
\hline DD & 437 & 400 & 0.92 & 35.3 \\
FF & 606 & 843 & 1.39 & 39.3 \\
GG & 829 & 1073 & 1.29 & 39.6 \\
EE & 528 & 1053 & 1.99 & 38.5 \\
L-4-12 & 730 & 782 & 1.07 & 39.5 \\
L-4-13 & 689 & 801 & 1.16 & 41.1 \\
L-4-18 & $700^{b}$ & 1007 & 1.43 & 39.8 \\
\hline
\end{tabular}

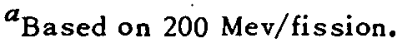

${ }^{b} \mathrm{Cs}^{137}$ analyses by gamma spectrometer (all others by beta spectrometer). 
Table 35. Analyses of Scale from L. 418

\begin{tabular}{|c|c|c|c|c|c|c|c|c|}
\hline \multirow{2}{*}{ Source of Scale } & \multirow{2}{*}{$\begin{array}{c}\text { Scale } \\
\text { Weight } \\
(\mathrm{mg})\end{array}$} & \multicolumn{7}{|c|}{ Scale Composition (wt \%) } \\
\hline & & $\mathrm{U}$ & $\mathrm{Z}_{\mathbf{r}}$ & $\mathrm{Fe}$ & $\mathrm{Ni}$ & $\mathrm{Cu}$ & $\mathrm{Cs}^{137}$ & $a$ \\
\hline Rear of core & 19.9 & 0.05 & 4.5 & 48.0 & 7.0 & 0.78 & 0 & 40 \\
\hline In-line annulus holders & 17.0 & 0.06 & 6.5 & 20.6 & 2.1 & 0.18 & 0 & 71 \\
\hline Pump volute & 6.5 & 0.21 & 13.3 & 42.7 & 3.5 & 9.0 & 0 & 31 \\
\hline
\end{tabular}

$a_{\text {Weight percent of scale not represented by listed constituents. }}$

temperatures. ${ }^{30,31}$ These indicate (1) negligible sorption of $\mathrm{Cs}^{137}$, (2) transport of an appreciable fraction of the zirconium oxide found in the core to regions outside the core, and (3) the fact that scales contain large amounts of nickel and small amounts of uranium.

Recently reported ${ }^{32}$ studies of sorption on zirconia in uranyl sulfate solutions show that some of the ions sorbed at high temperatures are removed by water-washing at room temperature or, possibly, by reversal of the sorption in uranyl sulfate solutions at low temperatures. Since all loops were rinsed with water at the completion of in-pile exposure, the possibility exists that for some elements such as uranium, cesium, and nickel, the amounts found in the scales are less than the amounts sorbed at high temperatures.

\subsubsection{Analyses for Uranium on Steel Surfaces from High-Power-Density Regions}

Analyses were performed on solutions containing the scale dissolved from one-half of the type 347 core channel coupon holder from experiment L-4-18. The analyses were carried out primarily to determine the amount of uranium on the steel surfaces. The as-removed holder half was sectioned into four approximately equal lengths. After being measured and weighed, these were treated separately with a $10 \% \mathrm{HC}$ solution, and one piece was treated with an $\mathrm{HCl}$ plus $\mathrm{HNO}_{3}$ solution. Visually, the samples appeared clean after this treatment. The solution samples were analyzed for uranium, copper, and zirconium.

Five to eight micrograms of uranium per $\mathrm{cm}^{2}$ was found on the steel surfaces, and there was little difference between amounts found at the front and the rear of the core. Copper ranged from 0 to $30 \mu \mathrm{g} / \mathrm{cm}^{2}$ and averaged $10 \mu \mathrm{g} / \mathrm{cm}^{2}$. No zirconium was found.

The importance of sorbed uranium in contributing to the fission recoil imadiation intensity at corroding surfaces has been discussed elsewhere. ${ }^{33}$ The contribution from the $10 \mu \mathrm{g} / \mathrm{cm}^{2}$ found here would not be significant, compared with that from the $0.17 \mathrm{~m} \mathrm{UO}_{2} \mathrm{SO}_{4}$ solution. However, as mentioned above, the

${ }^{30}$ G. H. J enks and J. E. Baker, HRP Radiation Corrosion Studies: In-Pile Loops L-2-15 and L-4-16, ORNL-3099 (in preparation).

${ }^{31}$ G. H. Jenks and J. E. Baker, HRP Radiation Corrosion Studies: In-Pile Loop L-2-17. ORNL-2974 (in prepara-

${ }^{32}$ G. H. Jenks et al., HRP Quart. Progr. Rept. Aug. 1-Nov. 30, 1960, ORNL-3061, pp 72-73.

${ }^{33}$ G. H. Jenks et al., HRP Quart. Progr. Rept., Jan. 31, 1958, ORNL-2493, p 126. 
possibility is not precluded that significant amounts may have been sorbed during high-temperature exposure.

\subsubsection{Results of Specimen Weight Measurements}

The results of weight measurements of specimens and other components are listed in Tables $36-42$, together with other data including calculated corrosion rate values, solution fission-power densities near specimens, and brief descriptions of specimens.

The zirconium-alloy corrosion rate values based on radiation time and total specimen area are plotted vs fission-power density in solution in Fig. 75 . The titanium rate values determined in like manner are shown in Fig. 76.

Evidence obtained in later 280 and $300^{\circ} \mathrm{C}$ experiments and described elsewhere shows that covered surfaces of Zircaloy-2 are attacked at the same or at greater rates than are the exposed surfaces. It is assumed that the corrosion behavior of zirconium alloys in these lower-temperature experiments was similar and that the rates calculated with total area as a basis are more nearly correct than those based on exposed surface only. Zircaloy -2 is known to corrode linearly with radiation time. For titanium alloys, no evidence is available with respect to relative corrosion of exposed and covered surfaces. It is assumed that in this respect these alloys are similar to Zircaloy-2.

As will be discussed later, the stainless steel in the core of most of these experiments did not corrode linearly with radiation time, and the listed rates are, generally, averages of two or more rates. Also, the relative amounts of corrosion on the covered and exposed surfaces are uncertain for many of the specimens Some of the specimens exposed to high solution velocities exhibited channeling (comparatively large rates on exposed surfaces), and, for these at least, the average rate values based on exposed surface areas are the most nearly correct.

For purposes of exhibiting and comparing steel corrosion in the various experiments, the exposed surface rates have been arbitrarily selected. Stainless steel rate values based on radiation time and exposed area are plotted in Figs. 77-81.

\section{DISCUSSION OF RESULTS}

\subsection{Solution Analyses}

The results of chemical analyses of the loop solutions during in-pile operation were subject to sampling errors resulting from dilution of the samples and to the usual uncertainties associated with remote analyses of radioactive solutions. No direct-control measurements were made of the accuracy of the overall sampling and subsequent chemical analyses, and it is necessary to estimate the significance of the results for the se early experiments from considerations of (1) interconsistency of analytical values for various species in samples, (2) results of solution analyses in subsequent loop experiments, and (3) established accuracy of analytical methods. 
Table 36. Corrosion Data for Stainless Steel Corrosion Specimens for Loop DD

\begin{tabular}{|c|c|c|c|c|c|c|c|c|c|c|c|c|c|}
\hline \multirow{2}{*}{$\begin{array}{l}\text { Sample } \\
\text { Number }\end{array}$} & \multirow[t]{2}{*}{ Position } & \multirow{2}{*}{$\begin{array}{l}\text { Exposed } \\
\text { Coupon } \\
\text { Area } \\
\left(\mathrm{cm}^{2}\right)\end{array}$} & \multirow{2}{*}{$\begin{array}{c}\text { Flow } \\
\text { Velocity } \\
\text { Leading } \\
\text { Edge } \\
\text { (fps) }\end{array}$} & \multirow{2}{*}{$\begin{array}{l}\text { Initial } \\
\text { Weight } \\
\text { (g) }\end{array}$} & \multirow{2}{*}{$\begin{array}{c}\text { As- } \\
\text { Removed } \\
\text { Weight } \\
\text { (g) }\end{array}$} & \multirow{2}{*}{$\begin{array}{l}\text { Defilmed } \\
\text { Weight } \\
\text { (g) }\end{array}$} & \multirow{2}{*}{$\begin{array}{l}\text { Weight } \\
\text { Loss } \\
\text { (mg) }\end{array}$} & \multirow{2}{*}{$\begin{array}{l}\text { Corrosion } \\
\text { Penetration } \\
\text { (mils) }\end{array}$} & \multicolumn{2}{|c|}{$\begin{array}{c}\text { Corrosion } \\
\operatorname{Rate}^{a}(\mathrm{mPy})\end{array}$} & \multirow{2}{*}{$\begin{array}{l}\text { Neutron Flux at } 3 \mathrm{Mw} \\
\text { (neutrons } \mathrm{cm}^{-2} \sec ^{-1} \text { ) }\end{array}$} & \multirow{2}{*}{$\begin{array}{l}\text { Power Den sity } \\
(w / \mathrm{ml})\end{array}$} & \multirow[t]{2}{*}{ Defilmed-Surface Appearance } \\
\hline & & & & & & & & & $465 \mathrm{hr}$ & $280 \mathrm{hr}$ & & & \\
\hline & & & & & & & & & & & $\times 10^{12}$ & & \\
\hline \multicolumn{2}{|c|}{$\begin{array}{l}\text { Core holder } \\
\text { No. } 11\end{array}$} & $\sim 160$ & . & & & & & & & & 0.73 & 0.82 & \\
\hline $436 \mathrm{~A}$ & A & 3.25 & 9.7 & 1.8985 & 1.7827 & 1.7786 & 119.9 & 1.81 & 34.0 & 56.7 & 1.56 & 174 & $\begin{array}{l}\text { Exposed surface heavily attacked; clamped } \\
\text { edges partially protected. }\end{array}$ \\
\hline $437 \mathrm{~A}$ & B & 2.80 & 11.3 & 1.8852 & 1.7952 & 1.7913 & 93.9 & 1.65 & 31.1 & 51.6 & 1.37 & 1.53 & $\begin{array}{l}\text { Exposed surface heavily attacked; clamped } \\
\text { edges partially protected }\end{array}$ \\
\hline $438 \mathrm{~A}$ & C & 280 & 13.7 & 2.9156 & 1.8310 & 1.8276 & 89.0 & 1.56 & 29.4 & 48.8 & 1. 20 & 1.34 & $\begin{array}{l}\text { Exposed surface heavily attacked; clamped } \\
\text { edges partially protected }\end{array}$ \\
\hline $439 \mathrm{~A}$ & D & 2.80 & 17.1 & 1.9072 & 1.8297 & 1.8274 & 79.8. & 1.40 & 26.4 & 43.8 & 1.06 & 1.18 & $\begin{array}{l}\text { Exposed surface heavily attacked; clamped } \\
\text { edges partially protected }\end{array}$ \\
\hline $440 \mathrm{~A}$ & E & 2.80 & 22.9 & 1.9104 & 1.8454 & 1.8426 & 67.8 & 1.19 & 22.4 & 37.2 & 0.88 & 0.99 & $\begin{array}{l}\sim 70 \% \text { of the exposed surface shows } \\
\text { shallow pits; clamped edges protected }\end{array}$ \\
\hline $441 \mathrm{~A}$ & $\mathrm{~F}$ & 2.80 & 35.8 & 1.9111 & 1.8555 & 1.8521 & 59.0 & 1.04 & 19.6 & 32.6 & 0.78 & 0.87 & $\begin{array}{l}\sim 50 \% \text { of the exposed surface shows } \\
\text { shallow pits; clamped edges protected }\end{array}$ \\
\hline $442 \mathrm{~A}$ & $\mathrm{G}$ & 2.80 & 41.5 & 1.9039 & 1.8694 & 1.8660 & 37.9 & 0.66 & 12.4 & 20.7 & 0.68 & 0.76 & $\begin{array}{l}\sim 20 \% \text { of the exposed surface shows } \\
\text { shallow pits; clamped edges protected }\end{array}$ \\
\hline $443 \mathrm{~A}$ & H & 2.80 & 50.5 & 1.8674 & L.8525 & 1.8481 & 19.3 & 0.34 & 6.4 & 10.6 & 0.60 & 0.67 & $\begin{array}{l}\sim 10 \% \text { of the exposed surface shows } \\
\text { shallow pits; clamped edges protected }\end{array}$ \\
\hline $444 \mathrm{~A}$ & I & 280 & 28.2 & 1.9138 & 1.9115 & 1.9022 & 11.6 & 0.20 & 3.8 & 6.3 & 0.48 & 0.54 & $\begin{array}{l}\text { Some very shallow pitting of exposed } \\
\text { surfaces }\end{array}$ \\
\hline $445 \mathrm{~A}$ & J & 2.80 & 19.9 & 1.8872 & 1.8947 & 1.8795 & 7.7 & 0.14 & 2.6 & 4.4 & 0.40 & 0.45 & $\begin{array}{l}\text { Machining marks quite clear, no apparent } \\
\text { pitting }\end{array}$ \\
\hline $446 \mathrm{~A}$ & $\mathrm{~K}$ & 280 & 15.2 & 1.9201 & 1.9303 & 1.9135 & 6.6 & 0.12 & 2.2 & 3.8 & 0.29 & 0.32 & $\begin{array}{l}\text { Machining marks quite clear; no apparent } \\
\text { pitting }\end{array}$ \\
\hline $447 A$ & $\mathrm{~L}$ & 3.00 & 12.1 & 18884 & 1.8990 & 1.8832 & 5.2 & 0.08 & 1.5 & 25 & 0.27 & 0.30 & $\begin{array}{l}\text { Machining marks quite clear; no apparent } \\
\text { pitting }\end{array}$ \\
\hline
\end{tabular}


Table 36. (continued)

\begin{tabular}{|c|c|c|c|c|c|c|c|c|c|c|c|c|c|}
\hline \multirow[t]{2}{*}{$\begin{array}{l}\text { Sample } \\
\text { Number }\end{array}$} & \multirow[t]{2}{*}{ Position } & \multirow{2}{*}{$\begin{array}{c}\text { Exposed } \\
\text { Coupon } \\
\text { Area } \\
\left(\mathrm{cm}^{2}\right)\end{array}$} & \multirow{2}{*}{$\begin{array}{c}\text { Flow } \\
\text { Velocity } \\
\text { Leading } \\
\text { Edge } \\
\text { (fps) }\end{array}$} & \multirow{2}{*}{$\begin{array}{l}\text { Initial } \\
\text { Weight } \\
\text { (g) }\end{array}$} & \multirow{2}{*}{$\begin{array}{c}\text { As- } \\
\text { Removed } \\
\text { Weight } \\
\text { (g) }\end{array}$} & \multirow{2}{*}{$\begin{array}{l}\text { Defilmed } \\
\text { Weight } \\
(\mathrm{g})\end{array}$} & \multirow{2}{*}{$\begin{array}{l}\text { Weight } \\
\text { Loss } \\
(\mathrm{mg})\end{array}$} & \multirow{2}{*}{$\begin{array}{l}\text { Corrosion } \\
\text { Penetration } \\
\text { (mils) }\end{array}$} & \multicolumn{2}{|c|}{$\begin{array}{c}\text { Corrosion } \\
\operatorname{Rate}^{a}(\mathrm{mpy})\end{array}$} & \multirow[t]{2}{*}{$\begin{array}{l}\text { Neutron Flux at } 3 \mathrm{~min} \\
\left(\text { neutron } \mathrm{sm}^{-2} \sec ^{-1}\right)\end{array}$} & \multirow[t]{2}{*}{$\begin{array}{l}\text { Power Density } \\
\qquad(\mathrm{w} / \mathrm{ml})\end{array}$} & \multirow[t]{2}{*}{ Defilmes-Surface Appearance } \\
\hline & & & & & & & & & $465 \mathrm{hr}$ & $280 \mathrm{hr}$ & & & \\
\hline $\begin{array}{l}\text { In-line ho } \\
\text { No. } 10\end{array}$ & lder & $\sim 160$ & & & & & & & & & & & \\
\hline $448 \mathrm{~A}$ & A & 3.00 & 9.4 & 1.9194 & 1.9277 & 1.9164 & 3.0 & 0.05 & 0.9 & 1.6 & & & $\begin{array}{l}\text { Machining marks clearly visible; some very } \\
\text { thin, black film remaining; no pitting }\end{array}$ \\
\hline $449 \mathrm{~A}$ & B & 2.80 & 10.9 & 1.8910 & 1.9004 & 18885 & 3.5 & 0.06 & 1.1 & 1.9 & & & $\begin{array}{l}\text { Machining marks clearly visible; some very } \\
\text { thin, black film remaining; no pitting }\end{array}$ \\
\hline $450 \mathrm{~A}$ & c & 2.80 & 13.2 & 1.9092 & 1.9191 & 19025 & 6.7 & 0.12 & 2.2 & 3.8 & & & $\begin{array}{l}\text { Hachining marks clearly visible; some very } \\
\text { thin, black film remaining; no pirting }\end{array}$ \\
\hline $451 A$ & D & 280 & 16.5 & 1.9191 & 1.9340 & 1.9172 & 1.9 & 0.03 & 0.6 & 0.9 & & & $\begin{array}{l}\text { Wachining marks clearly visible; some very } \\
\text { thin, black film remaining; no pitting }\end{array}$ \\
\hline $452 A$ & E & 2.80 & 22.1 & 18991 & 1.9096 & 18949 & 4.2 & 0.07 & 1.3 & 2.2 & & & $\begin{array}{l}\text { Machining marks clearly visible; some very } \\
\text { thin, black film remaining; no pitting }\end{array}$ \\
\hline $453 \mathrm{~A}$ & F & 2.80 & 34.6 & 1.8898 & 1.8995 & 1.8833 & 6.5 & 0.11 & 2.1 & 3.4 & & & $\begin{array}{l}\text { Machining marks clearly visible; some very } \\
\text { thin, black film remaining; no pitting }\end{array}$ \\
\hline $454 \mathrm{~A}$ & $\mathrm{G}$ & 280 & 40.1 & 1.8902 & 18982 & 1.8848 & 5.4 & 0.09 & 1.7 & 2.8 & & & $\begin{array}{l}\text { Machining marks clearly visible; some very } \\
\text { thin, black film remaining; no pitting }\end{array}$ \\
\hline $455 \mathrm{~A}$ & $\mathrm{H}$ & 2.80 & 48.8 & 1.9035 & 1.9122 & 1.9007 & 28 & 0.05 & 0.9 & 1.6 & & & $\begin{array}{l}\text { Machining marks clearly visible; some very } \\
\text { thin, black film remaining; no pirting }\end{array}$ \\
\hline $456 \mathrm{~A}$ & I & 2.80 & 27.2 & 1.8823 & 1.8904 & $i^{18794}$ & 2.9 & 0.05 & 0.9 & 1.6 & & & $\begin{array}{l}\text { Wachining marks clearly visible; some very } \\
\text { thin, black film remaining; no pitting }\end{array}$ \\
\hline $457 \mathrm{~A}$ & $\mathrm{~J}$ & 280 & 19.2 & 19113 & 1.9161 & 1.9055 & 5.8 & 0.10 & 1.8 & 3.1 & & & $\begin{array}{l}\text { Machining marks clearly visible; some very } \\
\text { thin, black film remaining; no pitting }\end{array}$ \\
\hline $458 \mathrm{~A}$ & $\mathrm{~K}$ & 2.80 & 14.7 & 1.9142 & 1.9200 & 19100 & 4.2 & 0.07 & 1.3 & 2.2 & & & $\begin{array}{l}\text { Machining marks clearly visible; some very } \\
\text { thin, black film remaining; no pitting }\end{array}$ \\
\hline $459 \mathrm{~A}$ & $\mathbf{L}$ & 3.00 & 11.7 & 1.9054 & 1.9116 & 1.9001 & 5.3 & 0.08 & 1.5 & 25 & & & $\begin{array}{l}\text { Machining marks clearly visible; some very } \\
\text { thin, black film remaining; no pitting }\end{array}$ \\
\hline
\end{tabular}

${ }^{a}$ Two corrosion rates are presented: total operation $465 \mathrm{hr}$ and radiation time with $3 \mathrm{Mwhr}$ equivalent to $1 \mathrm{hr}$. 
Table 37. Specimen Data for Loop EE

Distance Flow

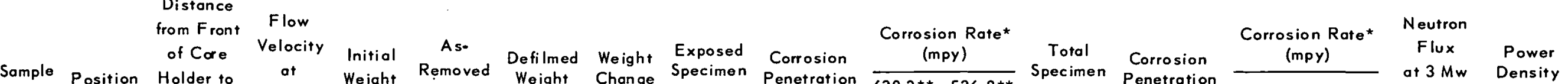

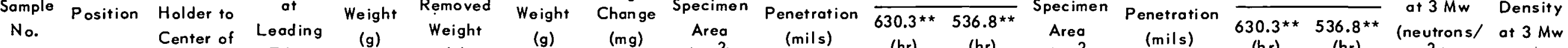

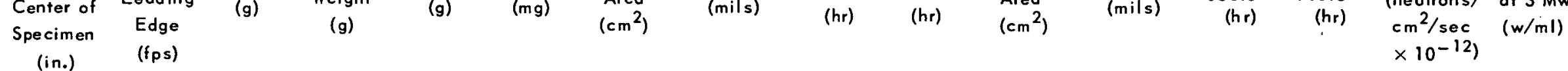

Surfoce Appearance

\section{Core Sample Coupons}

$\begin{array}{lllllllllll}\text { Type } & 347 & \text { Stainless } & \text { Steel Coupons } \\ 743 \mathrm{~A} & 4 & 0.88 & 11.8 & 0.9512 & 0.8465 & 0.8457 & -105.5 & 1.40 & 3.70\end{array}$

$\begin{array}{llllllllll}744 \mathrm{~A} & 5 & 1.13 & 13.1 & 0.9483 & 0.8514 & 0.8503 & -98.0 & 1.40 & 3.44\end{array}$

$\begin{array}{lllllllllll}745 \mathrm{~A} & 7 & 1.63 & 16.3 & 0.9474 & 0.8422 & 0.8413 & -106.1 & 1.40 & 3.72\end{array}$

$\begin{array}{llllllllll}746 \mathrm{~A} & 10 & 2.38 & 26.0 & 0.9630 & 0.9583 & 0.9582 & -4.8 & 1.40 & 0.17\end{array}$

$\begin{array}{lllllllllll}747 \mathrm{~A} & 13 & 3.13 & 39.2 & 0.9545 & 0.9521 & 0.9520 & -2.5 & 1.40 & 0.09\end{array}$

$\begin{array}{lllllllllll}784 \mathrm{~A} & 18 & 4.38 & 22.3 & 0.9583 & 0.9581 & 0.9576 & -0.7 & 1.40 & 0.02\end{array}$

$\begin{array}{lllllllllll}785 \mathrm{~A} & 21 & 5.13 & 14.4 & 0.9615 & 0.9621 & 0.9614 & -0.1 & 1.40 & 0.004\end{array}$

$\begin{array}{lllllllllll}787 \mathrm{~A} & 24 & 5.88 & 10.4 & 0.9627 & 0.9640 & 0.9626 & -0.1 & 1.57 & 0.003\end{array}$

Zircaloy-2 Coupons

$\begin{array}{llllllllll}\text { Zircaloy-2 Coupons } & & & & & & & & \\ \mathrm{Z} 19 & 2 & 0.38 & 9.9 & 0.7638 & 0.7591 & 0.7587 & -5.1 & 1.40 & 0.22\end{array}$

$\begin{array}{lllllllllll}z & 20 & 3 & 0.63 & 10.7 & 0.7672 & 0.7629 & 0.7623 & -4.9 & 1.40 & 0.21\end{array}$

$\begin{array}{lllllllllll}Z 21 & 8 & 1.88 & 18.6 & 0.7738 & 0.7695 & 0.7698 & -4.0 & 1.40 & 0.17\end{array}$

$\begin{array}{llllllllll}\mathrm{Z} 24 & 11 & 2.63 & 34.0 & 0.7754 & 0.7712 & 0.7725 & -2.9 & 1.40 & 0.13\end{array}$

$\begin{array}{lllllllllll}\text { Z } 26 & 14 & 3.38 & 42.5 & 0.7728 & 0.7698 & 0.7698 & -3.0 & 1.40 & 0.13 \\ \text { Z 27 } & .15 & 3.63 & 47.8 & 0.7671 & 0.7641 & 0.7645 & -2.6 & 1.40 & 0.11\end{array}$

$\begin{array}{lllllllllll}\mathrm{Z} 31 & 20 & 4.88 & 16.1 & 0.7626 & 0.7611 & 0.7609 & -1.7 & 1.40 & 0.07\end{array}$

$Z 37 \quad 23$

$\begin{array}{ll}51.3 & 59.9 \\ 47.4 & 55.6 \\ 51.2 & 60.2 \\ & \\ 2.3 & 2.8 \\ 1.2 & 1.5 \\ 0.3 & 0.3 \\ 0.1 & 0.1 \\ 0.04 & 0.05 \\ & \\ 3.1 & 3.6 \\ 2.9 & 3.4 \\ 2.3 & 2.8 \\ 1.8 & 2.1 \\ 1.8 & 2.1 \\ 1.5 & 1 . \\ 1.0 & 1.1 \\ 1.0 & 1.1\end{array}$

*Corrosion rates have been calculated both for the nominally exposed and the total specimen areas.
"*To corrosion rates are presented: one based on the total operation time of $630.3 \mathrm{hr}$ and one based on the total radiation time of $536.8 \mathrm{hr}$ ( 3 Mwhr of reactor time equivalent to $1 \mathrm{hr}$ of total radiation time).
Thin film, pickled appearance; clomped
edges were protected Thin film, pickled appearance; clamped Thin film on one side, heavy pickled Thin film on one side, heavy picklod
oppearnocei clamped edges were
protected

Thin film, some scale; machine mark $s$
visible Thin film on most of the surface,
pickled oppearance along one ed Filmonall surfaces; machine mark

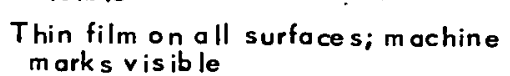
Thin film on all surfaces; machine
marks visible

Thin film on all surfoces, light etching; Thin film on all surfoces, light etching;
machine marks visible, Dark film on all surfaces; machine
mark s visible Some scalo retained in spots on all
surfaces Thin dark scale on all surfaces Thin dark film on all surfaces; some
white spots visible No apporent film; machine marks
clearly visible Thin dark film on all surfaces;
machine marks visible 
Table 37 (continued)

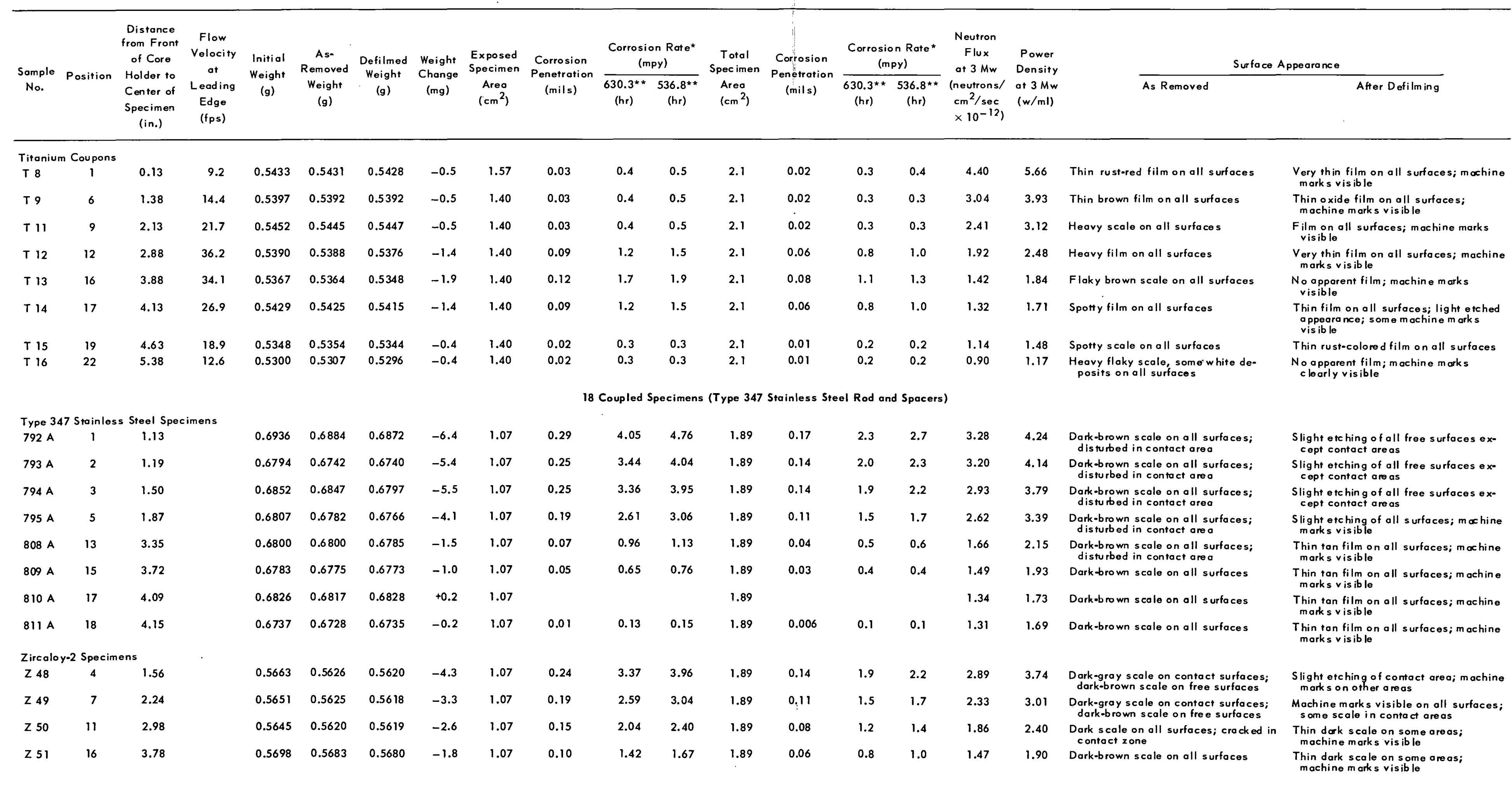

*Corosion rates have been calculated both for the nominally exposed and the total specimen areas.

**Two carrosion rates are presented: one based on the total operation time of $630.3 \mathrm{hr}$ and one based on the total radiation time of $536.8 \mathrm{hr}$ ( 3 Mwhr of reactor time equivalent to $1 \mathrm{hr}$ of total radiation time). 
Table 37 (continued)

\begin{tabular}{|c|c|c|c|c|c|c|c|c|c|c|c|c|c|c|c|c|c|c|c|c|}
\hline \multirow{2}{*}{$\begin{array}{l}\text { Sample } \\
\text { No. }\end{array}$} & \multirow{2}{*}{ Position } & \multirow{2}{*}{$\begin{array}{c}\text { Distance } \\
\text { from Front } \\
\text { of Core } \\
\text { Holder to } \\
\text { Center of } \\
\text { Specimen } \\
\text { (in.) }\end{array}$} & \multirow{2}{*}{$\begin{array}{c}\text { Flow } \\
\text { Velocity } \\
\text { at } \\
\text { Leading } \\
\text { Edge } \\
\text { (fps) }\end{array}$} & \multirow{2}{*}{$\begin{array}{c}\text { Initial } \\
\text { Weight } \\
\text { (g) }\end{array}$} & \multirow{2}{*}{$\begin{array}{c}\text { Ass- } \\
\text { Removed } \\
\text { Weight } \\
(g)\end{array}$} & \multirow{2}{*}{$\begin{array}{c}\text { Defilmed } \\
\text { Weight } \\
\text { (g) }\end{array}$} & \multirow{2}{*}{$\begin{array}{c}\text { Weight } \\
\text { Change } \\
\text { (mg) }\end{array}$} & \multirow{2}{*}{$\begin{array}{c}\text { Exposed } \\
\text { Specimen } \\
\text { Area } \\
\left(\mathrm{cm}^{2}\right)\end{array}$} & \multirow{2}{*}{$\begin{array}{c}\text { Corrosion } \\
\text { Penetration } \\
\text { (mils) }\end{array}$} & \multicolumn{2}{|c|}{$\begin{array}{c}\text { Corrosion Rote }{ }^{\star} \\
\quad(m p y)\end{array}$} & \multirow{2}{*}{$\begin{array}{c}\text { Total } \\
\text { Specimen } \\
\text { Area } \\
\left(\mathrm{cm}^{2}\right)\end{array}$} & \multirow{2}{*}{$\begin{array}{c}\text { Corrosion } \\
\text { Penetration } \\
\text { (mils) }\end{array}$} & \multicolumn{2}{|c|}{$\begin{array}{c}\text { Corrosion Rate* } \\
\text { (mpy) }\end{array}$} & \multirow{2}{*}{$\begin{array}{l}\text { Neutron } \\
\text { Flux } \\
\text { of } 3 \mathrm{Mw} \\
\text { (neutrons/ } \\
\mathrm{cm}^{2} / \mathrm{sec} \\
\dot{\times} 10^{-12} \text { ) }\end{array}$} & \multirow{2}{*}{$\begin{array}{l}\text { Power } \\
\text { Density } \\
\text { at } 3 \mathrm{Mw} \\
(\mathrm{w} / \mathrm{ml})\end{array}$} & \multirow{2}{*}{. } & \multicolumn{2}{|c|}{ Surface Appearance } \\
\hline & & & & & & & & & & $\begin{array}{c}630.3^{\star \star} \\
(\mathrm{hr})\end{array}$ & $\begin{array}{c}536.8^{\star \star} \\
(\mathrm{hr})\end{array}$ & & & $\begin{array}{c}630.3^{\star *} \\
(\mathrm{hr})\end{array}$ & $\begin{array}{c}536.8^{* *} \\
(\mathrm{hr})\end{array}$ & & & & Removed & After Defilming \\
\hline \multicolumn{21}{|c|}{ Titanium Specimens (55AX) } \\
\hline $\mathrm{T} 44$ & 6 & 1.93 & & 0.3938 & 0.3935 & 0.3939 & +0.1 & 1.07 & & & & 1.89 & & & & 2.58 & 3.34 & $\begin{array}{l}\text { Dark-brown scaje } \\
\text { turbed in contil }\end{array}$ & $\begin{array}{l}\text { e on oll surfaces; dis- } \\
\text { ct area a }\end{array}$ & $\begin{array}{l}\text { Thin dark film on all surfaces; machine } \\
\text { marks visible }\end{array}$ \\
\hline$T 46$ & 8 & 2.30 & & 0.3773 & 0.3760 & 0.3773 & 0.0 & 1.07 & 0.00 & 0.00 & 0.00 & 1.89 & 0.00 & 0.00 & 0.00 & 2.29 & 2.96 & $\begin{array}{l}\text { Dark-brown scale } \\
\text { turbed in contol }\end{array}$ & $\begin{array}{l}\text { e on all surfaces; dis- } \\
\text { ict area }\end{array}$ & $\begin{array}{l}\text { Machine marks visible on all surfaces; } \\
\text { some scale in contact zone }\end{array}$ \\
\hline T 47 & 9 & 2.61 . & & 0.3823 & 0.3818 & 0.3817 & -0.5 & 1.07 & 0.04 & 0.57 & 0.67 & 1.89 & 0.02 & 0.3 & 0.4 & 2.10 & 2.71 & $\begin{array}{l}\text { Darkebrown scale } \\
\text { turbed in contol }\end{array}$ & $\begin{array}{l}\text { eo on all surfaces; dis. } \\
\text { ct area a }\end{array}$ & $\begin{array}{l}\text { Thin dark film on all surfaces; machine } \\
\text { mark e visible }\end{array}$ \\
\hline T 50 & 10 & 2.67 & & 0.3869 & 0.3850 & 0.3865 & -0.4 & 1.07 & 0.03 & 0.45 & 0.53 & 1.89 & 0.02 & 0.3 & 0.3 & 2.07 & 2.68 & $\begin{array}{l}\text { Dark brown scale } \\
\text { turbed in contio }\end{array}$ & $\begin{array}{l}\text { le on all surfaces; dis. } \\
\text { act are a }\end{array}$ & $\begin{array}{l}\text { Thin dark film on all surfaces; machine } \\
\text { marks visible }\end{array}$ \\
\hline T 52 & 12 & 3.04 & & 0.3864 & 0.3856 & 0.3862 & -0.2 & 1.07 & 0.02 & 0.23 & 0.27 & 1.89 & 0.01 & 0.1 & 0.2 & 1.84 & 2.38 & $\begin{array}{l}\text { Dark scale on oll } \\
\text { contact zone }\end{array}$ & II surfaces; cracked in & $\begin{array}{l}\text { Thin dark film on all surfaces; machine } \\
\text { marks visible }\end{array}$ \\
\hline$T 53$ & 14 & 3.41 & & 0.3979 & 0.3971 & 0.3973 & -0.6 & 1.07 & 0.05 & 0.67 & 0.79 & 1.89 & 0.03 & 0.4 & 0.5 & 1.64 & 2.12 & $\begin{array}{l}\text { Dark-brown scale } \\
\text { turbod in contio. }\end{array}$ & $\begin{array}{l}\text { eo on all suffaces; dis. } \\
\text { ct area }\end{array}$ & $\begin{array}{l}\text { Thin dark scale on some areas; mar } \\
\text { chine marks visible }\end{array}$ \\
\hline \multicolumn{21}{|c|}{ Type 347 Stainless Steel Spacers } \\
\hline si & 1 & 0.97 & & 0.5966 & 0.5853 & 0.5843 & -12.3 & 2.23 & 0.27 & 3.73 & 4.38 & 2.42 & 0.25 & 3.4 & 4.0 & 3.32 & 4.29 & & & \\
\hline 52 & 2 & 1.34 & & 0.6123 & 0.6044 & 0.6032 & -9.1 & 2.23 & 0.20 & 2.76 & 3.24 & 2.42 & 0.18 & 2.5 & 3.0 & 2.95 & 3.81 & & & \\
\hline 53 & 3 & 1.71 & & 0.6140 & 0.6083 & 0.6070 & -7.0 & 2.23 & 0.15 & 2.12 & 2.49 & 2.42 & 0.14 & 2.0 & 2.3 & 2.65 & 3.42 & & & \\
\hline 54 & 4 & 2.08 & & 0.5545 & 0.5499 & 0.5486 & -5.9 & 2.23 & 0.13 & 1.79 & 2.10 & 2.42 & 0.12 & 1.7 & 1.9 & 2.49 & 3.22 & & & \\
\hline S 5 & 5 & 2.45 & & 0.5958 & 0.5932 & 0.5917 & -4.1 & 2.23 & 0.09 & 1.24 & 1.46 & 2.42 & 0.08 & 1.1 & 1.4 & 2.27 & 2.93 & & & \\
\hline s6 & 6 & 2.82 & & 0.5524 & 0.5519 & 0.5490 & -3.4 & 2.23 & 0.08 & 1.03 & 1.21 & 2.42 & 0.07 & 1.0 & 1.1 & 2.05 & 2.65 & & & \\
\hline 57 & 7 & 3.19 & & 0.5726 & 0.5715 & 0.5700 & -2.6 & 2.23 & 0.06 & 0.79 & 0.93 & 2.42 & 0.05 & 0.7 & 0.9 & 1.69 & 2.18 & & & \\
\hline S 8 & 8 & 3.56 & & 0.5543 & 0.5542 & 0.5525 & -1.8 & 2.23 & 0.04 & 0.55 & 0.65 & 2.42 & 0.04 & 0.5 & 0.6 & 1.37 & 1.77 & & & \\
\hline s 9. & 9 & 3.93 & & 0.5782 & 0.5775 & 0.5772 & -1.0 & 2.23 & 0.02 & 0.30 & 0.35 & 2.42 & 0.02 & 0.3 & 0.3 & 1.21 & 1.57 & & & \\
\hline S 10 & 10 & 4.30 & & 0.5483 & 0.5462 & 0.5475 & -0.8 & 2.23 & 0.02 & 0.25 & 0.29 & 2.42 & 0.02 & 0.2 & 0.3 & 1.14 & 1.47 & & & \\
\hline \multicolumn{21}{|c|}{18 Coupled Specimens (Zircaloy-2 Rod and Spacers) } \\
\hline \multicolumn{21}{|c|}{ Type 347 Stainless Steel Specimens } \\
\hline $788 \mathrm{~A}$ & 4 & 1.56 & & 0.6927 & 0.6867 & 0.6853 & -7.4 & 1.07 & 0.34 & 4.7 & 5.5 & 1.89 & 0.19 & 2.7 & 3.1 & 2.89 & 3.74 & $\begin{array}{l}\text { Dark scale on dill } \\
\text { in contact area }\end{array}$ & II surfaces; disturbed & $\begin{array}{l}\text { Dark speck led s cole on free surfaces; } \\
\text { brown in contact zone }\end{array}$ \\
\hline $789 \mathrm{~A}$ & 5 & 1.87 & & 0.6896 & 0.6836 & 0.6827 & -6.9 & 1.07 & 0.32 & 4.4 & 5.1 & 1.89 & 0.18 & 2.5 & 2.9 & 2.61 & 3.37 & $\begin{array}{l}\text { Dork scale on oll } \\
\text { in contact orel }\end{array}$ & II surfaces; disturbed & Dark, salted scale on all surfaces \\
\hline $790 \mathrm{~A}$ & 13 & 3.35 & & 0.6908 & 0.6882 & 0.6867 & -4.1 & 1.07 & 0.19 & 2.6 & 3.0 & 1.89 & 0.11 & 1.5 & 1.7 & 1.67 & 2.16 & $\begin{array}{l}\text { Dark scale on oll } \\
\text { in contact arelo }\end{array}$ & II surfaces; disturbed & Dark, salted scale on all surfaces \\
\hline $791 \mathrm{~A}$ & 15 & 3.72 & & 0.6905 & 0.6899 & 0.6876 & -2.9 & 1.07 & 0.13 & 1.8 & 2.2 & 1.89 & 0.08 & 1.0 & 1.2 & 1.50 & 1.94 & $\begin{array}{l}\text { Dark scale on qull } \\
\text { in contact areal }\end{array}$ & II surfaces; disturbed & Dark, salted scale on all surfaces \\
\hline
\end{tabular}


Table 37 (continued)

\begin{tabular}{|c|c|c|c|c|c|c|c|c|c|c|c|c|c|c|c|c|c|c|c|}
\hline \multirow{2}{*}{$\begin{array}{l}\text { Sample } \\
\text { No. }\end{array}$} & \multirow{2}{*}{ Position } & \multirow{2}{*}{$\begin{array}{c}\text { Distance } \\
\text { from Front } \\
\text { of Core } \\
\text { Holder to } \\
\text { Center of } \\
\text { Specimen } \\
\text { (in.) }\end{array}$} & \multirow{2}{*}{$\begin{array}{l}\text { Flow } \\
\text { Velocity } \\
\text { at } \\
\text { Leoding } \\
\text { Edge } \\
\text { (fps) }\end{array}$} & \multirow{2}{*}{$\begin{array}{c}\text { Initial } \\
\text { Weight } \\
\text { (g) }\end{array}$} & \multirow{2}{*}{$\begin{array}{c}\text { Ass- } \\
\text { Removed } \\
\text { Weight } \\
\text { (g) }\end{array}$} & \multirow{2}{*}{$\begin{array}{c}\text { Defilmed } \\
\text { Weight } \\
\text { (g) }\end{array}$} & \multirow{2}{*}{$\begin{array}{l}\text { Weight } \\
\text { Change } \\
\text { (mg) }\end{array}$} & \multirow{2}{*}{$\begin{array}{c}\text { Exposed } \\
\text { Specimen } \\
\text { Area } \\
\left(\mathrm{cm}^{2}\right)\end{array}$} & \multirow{2}{*}{$\begin{array}{l}\text { Corrosion } \\
\text { Penetration } \\
\text { (mils) }\end{array}$} & \multicolumn{2}{|c|}{$\begin{array}{c}\text { Corrosion Rate* } \\
\text { (mpy) }\end{array}$} & \multirow{2}{*}{$\begin{array}{c}\text { Total } \\
\text { Specimen } \\
\text { Area } \\
\left(\mathrm{cm}^{2}\right)\end{array}$} & \multirow{2}{*}{$\begin{array}{l}\text { Corrosion } \\
\text { Penetration } \\
\text { (mils) }\end{array}$} & \multicolumn{2}{|c|}{$\begin{array}{c}\text { Corrosion Rate* } \\
(\mathrm{mpy})\end{array}$} & \multirow{2}{*}{$\begin{array}{l}\text { Neutron } \\
\text { Flux } \\
\text { ot } 3 \mathrm{Mw} \\
\text { (neutrons/ } \\
\mathrm{cm}^{2} / \mathrm{sec} \\
\times 10^{-12} \text { ) }\end{array}$} & \multirow{2}{*}{$\begin{array}{l}\text { Power } \\
\text { Density } \\
\text { ot } 3 M_{w} \\
(w / m l)\end{array}$} & \multicolumn{2}{|c|}{ Surface Appearance } \\
\hline & & & & & & & & & & $\begin{array}{c}630.3^{* \star} \\
(\mathrm{hr})\end{array}$ & $\begin{array}{c}536.8^{\star \star \star} \\
(h r)\end{array}$ & & & $\begin{array}{c}630.3^{* \star} \\
(\mathrm{hr})\end{array}$ & $\begin{array}{c}536.8^{\star \star} \\
(\mathrm{hr})\end{array}$ & & & As Removed & After Defilm ing \\
\hline \multicolumn{20}{|c|}{ Zircaloy-2 Specimens } \\
\hline z 40 & 1 & 1.13 & & 0.5556 & 0.5513 & 0.5503 & -5.3 & 1.07 & 0.30 & 4.1 & 4.9 & 1.89 & 0.17 & 2.3 & 2.8 & 3.29 & 4.25 & $\begin{array}{l}\text { Dark scale on all surfaces; disturbed } \\
\text { in contact area }\end{array}$ & Dark, solted scale on all surfaces \\
\hline z 41 & 2 & 1.19 & & 0.5772 & 0.5731 & 0.5726 & -4.6 & 1.07 & 0.26 & 3.6 & 4.2 & 1.89 & 0.15 & 2.0 & 2.4 & 3.21 & 4.15 & $\begin{array}{l}\text { Dark scale on all surfaces; disturbed } \\
\text { in contact area }\end{array}$ & Dark, solted scale on all surfaces \\
\hline z 42 & 3 & 1.50 & & 0.5686 & 0.5648 & 0.5644 & -4.2 & 1.07 & 0.24 & 3.3 & 3.8 & 1.89 & 0.13 & 1.9 & 2.2 & 2.92 & 3.77 & $\begin{array}{l}\text { Dark scale on all surfaces; disturied } \\
\text { in contact area }\end{array}$ & Dark, salted scale on all surfaces \\
\hline z 43 & 7 & 2.24 & & 0.5701 & 0.5675 & 0.5658 & -4.3 & 1.07 & 0.24 & 3.4 & 4.0 & 1.89 & 0.14 & 1.9 & 2.2 & 2.32 & 3.00 & $\begin{array}{l}\text { Dark scale.on all surfaces; disturbed } \\
\text { in contact area }\end{array}$ & Dark, salted s cale on all surfaces \\
\hline Z 44 & 11 & 2.98 & & 0.5539 & 0.5511 & 0.5502 & -3.7 & 1.07 & 0.21 & 2.9 & 3.4 & 1.89 & 0.12 & 1.6 & 1.9 & 1.87 & 2.42 & $\begin{array}{l}\text { Dark scale on all surfaces; distubed } \\
\text { in contact area }\end{array}$ & Dark, salted scale on all surface s \\
\hline 245 & 16 & 3.78 & & 0.5605 & 0.5581 & 0.5574 & -3.1 & 1.07 & 0.18 & 2.4 & 2.8 & 1.89 & 0.10 & 1.4 & 1.6 & 1.47 & 1.90 & $\begin{array}{l}\text { Dark scale on all surfaces; disturbed } \\
\text { in contoct area }\end{array}$ & Dark, salted scale on all surfaces \\
\hline z 46 & 17 & 4.09 & & 0.5628 & 0.5608 & 0.5594 & -3.4 & 1.07 & 0.19 & 2.6 & 3.1 & 1.89 & 0.11 & 1.5 & 1.8 & 1.34 & 1.73 & $\begin{array}{l}\text { Dark scale on all surfaces; disturbed } \\
\text { in contact area }\end{array}$ & Dark, salted scale on all surfaces \\
\hline Z 47 & 18 & 4.15 & & 0.5732 & 0.5712 & 0.5699 & -3.3 & 1.07 & 0.19 & 2.6 & 3.0 & 1.89 & 0.11 & 1.5 & 1.7 & 1.31 & 1.69 & $\begin{array}{l}\text { Dark scale on all surfaces; disturbed } \\
\text { in contact area }\end{array}$ & Dark, salted scale on all surface s \\
\hline \multicolumn{20}{|c|}{ Titanium Specimens (55AX) } \\
\hline T 25 & 6 & 1.93 & & 0.3825 & 0.3826 & 0.3824 & -0.1 & 1.07 & 0.01 & 0.1 & 0.1 & 1.89 & 0.01 & 0.1 & 0.1 & 2.54 & 3.28 & $\begin{array}{l}\text { Dark scale on all surfaces; disturbed } \\
\text { in contact area }\end{array}$ & Dark, saited scale on all surface s \\
\hline T 26 & 8 & 2.30 & & 0.3857 & 0.3866 & 0.3858 & +0.1 & 1.07 & & & & 1.89 & & & & 2.30 & 2.97 & $\begin{array}{l}\text { Dark scale on all surfaces; disturbed } \\
\text { in contact area }\end{array}$ & Dark brown scale on all surfaces \\
\hline T 27 & 9 & 2.61 & & 0.3864 & 0.3871 & 0.3864 & 0.0 & 1.07 & 0.00 & 0.0 & 0.0 & 1.89 & 0.00 & 0.0 & 0.0 & 2.09 & 2.70 & $\begin{array}{l}\text { Dark scale on all surfaces; disturbed } \\
\text { in contact area }\end{array}$ & $\begin{array}{l}\text { Dark brown film on free surfaces; scale } \\
\text { on contact ore as }\end{array}$ \\
\hline T 29 & 10 & 2.67 & & 0.3911 & 0.3913 & 0.3914 & +0.3 & 1.07 & & & & 1.89 & & & & 2.07 & 2.67 & $\begin{array}{l}\text { Dark scale on all surfaces; disturithed } \\
\text { in contact area }\end{array}$ & $\begin{array}{l}\text { Dark brown film on free surfaces; scale } \\
\text { on contact areas }\end{array}$ \\
\hline T 38 & 12 & 3.04 & & 0.3912 & 0.3916 & 0.3915 & +0.3 & 1.07 & & & & 1.89 & & & & 1.83 & 2.36 & $\begin{array}{l}\text { Dark scale on all surfaces; disturbed } \\
\text { in contact area }\end{array}$ & $\begin{array}{l}\text { Dark brown film on free surfaces; scale } \\
\text { on contact areas }\end{array}$ \\
\hline T 42 & 14 & 3.41 & & 0.3780 & 0.3782 & 0.3771 & -0.9 & 1.07 & 0.08 & 1.1 & 1.2 & 1.89 & 0.04 & 0.6 & 0.7 & 1.64 & 2.12 & $\begin{array}{l}\text { Dark scale on all surfaces; disturbed } \\
\text { in contact area }\end{array}$ & $\begin{array}{l}\text { Dark brown film on free surfaces; scale } \\
\text { on contact areas }\end{array}$ \\
\hline \multicolumn{20}{|c|}{ Zircaloy-2 Spacers } \\
\hline z 1 & 1 & 0.97 & & 0.5210 & 0.5179 & 0.5179 & -3.1 & 2.23 & 0.07 & 0.9 & 1.1 & 2.42 & 0.06 & 0.9 & 1.0 & 3.45 & 4.46 & & \\
\hline$z_{2}$ & 2 & 1.34 & & 0.5207 & 0.5188 & 0.5122 & -8.5 & 2.23 & 0.19 & 2.6 & 3.0 & 2.42 & 0.17 & 2.4 & 2.8 & 3.14 & 4.06 & & \\
\hline 23 & 3 & 1.71 & & 0.5190 & 0.5113 & 0.5112 & -7.8 & 2.23 & 0.17 & 2.4 & 2.8 & 2.42 & 0.16 & 2.2 & 2.6 & 3.04 & 3.93 & & \\
\hline $\mathrm{z}_{4}$ & 4 & 2.08 & & 0.5245 & 0.5224 & 0.5160 & -8.5 & 2.23 & 0.19 & 2.6 & 3.0 & 2.42 & 0.17 & 2.4 & 2.8 & 2.77 & 3.58 & & \\
\hline 25 & 5 & 2.45 & & 0.5183 & 0.5168 & 0.5105 & -7.8 & 2.23 & 0.17 & 2.4 & 2.8 & 2.42 & 0.16 & 2.2 & 2.6 & 2.32 & 2.99 & & \\
\hline Z 6 & 6 & 2.82 & & 0.5317 & 0.5308 & 0.5251 & -6.6 & 2.23 & 0.15 & 2.0 & 2.4 & 2.42 & 0.13 & 1.8 & 2.2 & 2.07 & 2.68 & & \\
\hline $\mathrm{Z}_{7}$ & 7 & 3.19 & & 0.5199 & 0.5150 & 0.5131 & -6.8 & 2.23 & 0.15 & 2.1 & 2.4 & 2.42 & 0.14 & 1.9 & 2.2 & 1.78 & 2.31 & & \\
\hline Z 8 & 8 & 3.56 & & 0.5244 & 0.5200 & 0.5192 & -5.2 & 2.23 & 0.12 & 1.6 & 1.9 & 2.42 & 0.11 & 1.5 & 1.7 & 1.72 & 2.22 & & \\
\hline Z 9 & 9 & 3.93 & & 0.5228 & 0.5183 & 0.5159 & -6.9 & 2.23 & 0.15 & 2.1 & 2.5 & 2.42 & 0.14 & 1.9 & 2.3 & 1.71 & 2.21 & & \\
\hline 210 & 10 & 4.30 & & 0.5163 & 0.5135 & 0.5113 & -5.0 & 2.23 & 0.11 & 1.5 & 1.8 & 2.42 & 0.10 & 1.4 & 1.6 & 1.34 & 1.74 & & \\
\hline
\end{tabular}


Table 37 (continued)

\begin{tabular}{|c|c|c|c|c|c|c|c|c|c|c|c|c|c|c|c|c|c|c|c|}
\hline \multirow{2}{*}{$\begin{array}{l}\text { Sample } \\
\text { No. }\end{array}$} & \multirow{2}{*}{ Position } & \multirow{2}{*}{$\begin{array}{c}\text { Distance } \\
\text { from Front } \\
\text { of Core } \\
\text { Holder to } \\
\text { Center of } \\
\text { Specimen } \\
\text { (in.) }\end{array}$} & \multirow{2}{*}{$\begin{array}{l}\text { Flow } \\
\text { Velocity } \\
\text { at } \\
\text { Leading } \\
\text { Edge } \\
\text { (fps) }\end{array}$} & \multirow{2}{*}{$\begin{array}{l}\text { Initial } \\
\text { Weight } \\
\text { (g) }\end{array}$} & \multirow{2}{*}{$\begin{array}{l}\text { Ass } \\
\text { Removed } \\
\text { Weight } \\
\text { (g) }\end{array}$} & \multirow{2}{*}{$\begin{array}{l}\text { Defilmed } \\
\text { Weight } \\
\text { (g) }\end{array}$} & \multirow{2}{*}{$\begin{array}{l}\text { Weight } \\
\text { Change } \\
\text { (mg) }\end{array}$} & \multirow{2}{*}{$\begin{array}{c}\text { Exposed } \\
\text { Specimen } \\
\text { Area } \\
\left(\mathrm{cm}^{2}\right)\end{array}$} & \multirow{2}{*}{$\begin{array}{l}\text { Corrosion } \\
\text { Penetration } \\
\text { (mils) }\end{array}$} & \multicolumn{2}{|c|}{$\begin{array}{c}\begin{array}{c}\text { Corrosion Rate } \\
\text { (mpy) }\end{array} \\
\end{array}$} & \multirow{2}{*}{$\begin{array}{c}\text { Total } \\
\text { Specimen } \\
\text { Area } \\
\left(\mathrm{cm}^{2}\right)\end{array}$} & \multirow{2}{*}{$\begin{array}{l}\text { Corrosion } \\
\text { Penetration } \\
\quad \text { (mils) }\end{array}$} & \multicolumn{2}{|c|}{$\begin{array}{c}\text { Corrosion Rate } \\
(\mathrm{mpy})\end{array}$} & \multirow{2}{*}{$\begin{array}{c}\text { Neutron } \\
\text { Flux } \\
\text { of } 3 \mathrm{Mw} \\
\text { (neutrons/ } \\
\mathrm{cm}^{2} / \mathrm{sec}^{-12} \\
\times \times 10^{-12} \text { ) }\end{array}$} & \multirow{2}{*}{$\begin{array}{l}\text { Power } \\
\text { Density } \\
\text { ot } 3 \mathrm{Mw} \\
(\mathrm{w} / \mathrm{ml})\end{array}$} & \multicolumn{2}{|c|}{ Surface Appearance } \\
\hline & & & & & & & & & & $\begin{array}{c}630.3^{* *} \\
(\mathrm{hr})\end{array}$ & $\begin{array}{c}536.8^{* *} \\
(\mathrm{hr})\end{array}$ & & & $\begin{array}{c}630.3^{\star \star} \\
(\mathrm{hr})\end{array}$ & $\begin{array}{c}536.8^{\star \star} \\
(\mathrm{hr})\end{array}$ & & & As Removed & After Defilming \\
\hline
\end{tabular}

In-Line Corrosion Sample Coupons

\begin{tabular}{|c|c|c|c|c|c|c|c|c|c|c|c|c|c|c|}
\hline Type 3 & Stain & & & & & & & & & & & & & \\
\hline $736 \mathrm{~A}$ & 4 & 11.8 & 0.9547 & 0.9608 & 0.9524 & -2.3 & 1.40 & 0.08 & 1.1 & 1.3 & 2.1 & 0.05 & 0.8 & 0.9 \\
\hline $737 \mathrm{~A}$ & 5 & 13.1 & 0.9547 & 0.9606 & 0.9540 & -0.7 & 1.40 & 0.03 & 0.4 & 0.4 & 2.1 & 0.02 & 0.2 & 0.3 \\
\hline $738 \mathrm{~A}$ & 7 & 16.3 & 0.9526 & 0.9585 & 0.9506 & -2.0 & 1.40 & 0.07 & 1.0 & 1.1 & 2.1 & 0.05 & 0.7 & 0.8 \\
\hline $739 \mathrm{~A}$ & 10 & 26.0 & 0.9396 & 0.9453 & 0.9392 & -0.4 & 1.40 & 0.01 & 0.2 & 0.2 & 2.1 & 0.01 & 0.1 & 0.2 \\
\hline $740 \mathrm{~A}$ & 13 & 39.2 & 0.9509 & 0.9557 & & & 1.40 & & & & 2.1 & & & \\
\hline $741 \mathrm{~A}$ & 18 & 22.3 & 0.9532 & 0.9570 & 0.9528 & -0.4 & 1.40 & 0.01 & 0.2 & 0.2 & 2.1 & 0.01 & 0.1 & 0.2 \\
\hline $742 \mathrm{~A}$ & 21 & 14.4 & 0.9504 & 0.9538 & 0.9499 & -0.5 & 1.40 & 0.02 & 0.3 & 0.3 & 2.1 & 0.01 & 0.2 & 0.2 \\
\hline $786 \mathrm{~A}$ & 24 & 10.4 & 0.9653 & 0.9691 & 0.9651 & -0.2 & 1.57 & 0.01 & 0.1 & 0.1 & 2.1 & 0.004 & 0.1 & \\
\hline
\end{tabular}

Zircaloy-2 Coupons
$Z 1$

$1.57 \quad 0.01$

$\begin{array}{rlllll}9.9 & 0.7701 & 0.7750 & 0.7704 & +0.3 & 1.40 \\ 10.7 & 0.7727 & 0.7785 & 0.7729 & +0.2 & 1.40 \\ 18.6 & 0.7575 & 0.7636 & 0.7576 & +0.1 & 1.40 \\ 34.0 & 0.7593 & 0.7653 & & & 1.40 \\ 42.5 & 0.7676 & 0.7727 & 0.7678 & +0.2 & 1.40 \\ 47.8 & 0.7749 & 0.7795 & 0.7751 & +0.2 & 1.40 \\ 16.1 & 0.7690 & 0.7734 & 0.7692 & +0.2 & 1.40 \\ 11.5 & 0.7651 & 0.7701 & 0.7654 & +0.3 & 1.40\end{array}$

2.1
2.1
2.1
2.1
2.1
2.1
2.1
2.1

Heavy rust-colored scale on all
surfaces
Heavy rust-colored scale on all
surfaces
Heary rust-colored scale on all
surfaces
Heavy rust-colored scale on all
surfaces
Heavy rust-colored scale on all
surfoces
Heavy rust-colored scale on all
surfaces
Heavy rust-colored scale on all
surfaces
Heavy rust-colored scale on all
surfaces

Heavy rust-colored scale on all surfaces
Heavy rust-colored scale on all Heavy rusicace
surfaces

Heavy rust-colored scale on all
surfaces Heavy rust-colored scale on al Heavy rust-c olored scale on all
surfaces Heavy rust-colored scale on all
surfaces surfaces
Heavy rust-colored scale on all Heavy rust-colored scale on all
Clean; mochine marks visible Clean; machine marks sis ible Slight staining of oll surfoces; $m \sigma o$
chine marks $s$ visible Clean; machine mark s visible

Clean; mochine marks visible Clean; mochine marks visible Cle an; machine marks visible

Thin film on all surfaces; no mochine
marks visible Thin film on all surfaces; no machine
marks $v$ is ib le Thin film on all surfaces

Thin film on all surfaces Thin film on all surfaces Clean; machine marks visible

*Corrosion rates have been calculated both for the nominally exposed and the total specimen areas.

**Two corro sion rates are pre sented: one based on the total operation time of $630.3 \mathrm{hr}$ and one based on the total radiation time of $536.8 \mathrm{hr}$ ( 3 Mwhr of reactor time equivalent to $1 \mathrm{hr}$ of total radiation time). 


\begin{tabular}{|c|c|c|c|c|c|c|c|c|c|c|c|c|c|c|c|c|c|c|c|}
\hline \multirow{2}{*}{$\begin{array}{l}\text { Sample } \\
\text { No. }\end{array}$} & \multirow{2}{*}{ Position } & \multirow{2}{*}{$\begin{array}{c}\text { Distance } \\
\text { from Front } \\
\text { of Core } \\
\text { Holder to } \\
\text { Center of } \\
\text { Specimen } \\
\text { (in.) }\end{array}$} & \multirow{2}{*}{$\begin{array}{l}\text { Flow } \\
\text { Velocity } \\
\text { at } \\
\text { Leading: } \\
\text { Edge } \\
\text { (fps) }\end{array}$} & \multirow{2}{*}{$\begin{array}{l}\text { Initial } \\
\text { Weight } \\
(g)\end{array}$} & \multirow{2}{*}{$\begin{array}{c}\text { As- } \\
\text { Removed } \\
\text { Weight } \\
\text { (g) }\end{array}$} & \multirow{2}{*}{$\begin{array}{l}\text { Defilmed } \\
\text { Weight } \\
\text { (g) }\end{array}$} & \multirow{2}{*}{$\begin{array}{c}\text { Weight } \\
\text { Change } \\
\text { (mg) }\end{array}$} & \multirow{2}{*}{$\begin{array}{c}\text { Exposed } \\
\text { Specimen } \\
\text { Area } \\
\left(\mathrm{cm}^{2}\right)\end{array}$} & \multirow{2}{*}{$\begin{array}{l}\text { Corrosion } \\
\text { Penetrotion } \\
\text { (mils) }\end{array}$} & \multicolumn{2}{|c|}{$\begin{array}{c}\text { Corrosion Rote* } \\
\text { (mpy) } \\
\end{array}$} & \multirow{2}{*}{$\begin{array}{c}\text { Total } \\
\text { Specimen } \\
\text { Area } \\
\left(\mathrm{cm}^{2}\right)\end{array}$} & \multirow{2}{*}{$\begin{array}{c}\text { Corlosion } \\
\text { Penotration } \\
\text { (mils) }\end{array}$} & \multicolumn{2}{|c|}{$\begin{array}{c}\text { Corosion Rate* } \\
(\mathrm{mpy})\end{array}$} & \multirow{2}{*}{$\begin{array}{l}\text { Neutron } \\
\text { Flux } \\
\text { of } 3 \mathrm{Mw} \\
\text { (neutrons/ } \\
\mathrm{cm}^{2} / \mathrm{sec} \\
\times 10^{-12} \text { ) }\end{array}$} & \multirow{2}{*}{$\begin{array}{l}\text { Power } \\
\text { Density } \\
\text { at } 3 \mathrm{Mw} \\
(w / \mathrm{ml})\end{array}$} & \multirow{2}{*}{\multicolumn{2}{|c|}{ Surface Appearance }} \\
\hline & & & & & & & & & & $\begin{array}{c}\begin{array}{c}630.3^{* \star} \\
(\mathrm{hr})\end{array} \\
\end{array}$ & $\begin{array}{c}536.8^{\star \star} \\
(\mathrm{hr})\end{array}$ & & & $\begin{array}{l}630.3^{* *} 5 \\
(\mathrm{hr})\end{array}$ & $\begin{array}{c}536.8^{\star \star \star} \\
(h r)\end{array}$ & & & & \\
\hline \multicolumn{20}{|c|}{ Titonium (55 AX) Coupons } \\
\hline To & 1 & & 9.2 & 0.5340 & 0.5379 & 0.5321 & -1.9 & 1.57 & 0.11 & 1.5 & 1.7 & 2.1 & & 1.1 & 1.3 & & & $\begin{array}{l}\text { Heavy rust-colored scale on all } \\
\text { surfaces }\end{array}$ & $\begin{array}{l}\text { Clean; slight stain on one side; noma- } \\
\text { chine marks visible }\end{array}$ \\
\hline T 1 & 6 & & 14.4 & 0.5354 & 0.5412 & 0.5353 & -0.1 & 1.40 & 0.006 & 0.1 & 0.1 & 2.1 & & 0.1 & 0.1 & & & $\begin{array}{l}\text { Heavy rust-colored scale on all } \\
\text { surfaces }\end{array}$ & Clean; machine marks visible \\
\hline T 2 & 9 & & 21.7 & 0.5384 & 0.5445 & 0.5383 & -0.1 & 1.40 & 0.006 & 0.1 & 0.1 & 2.1 & $0 ! 004$ & 0.1 & 0.1 & & & $\begin{array}{l}\text { Heavy rust-colored scale on all } \\
\text { surfaces }\end{array}$ & $\begin{array}{l}\text { Slight stain on one side; } m \propto x \text { hine } \\
\text { marks visible }\end{array}$ \\
\hline T 3 & 12 & & 36.2 & 0.5379 & 0.5428 & & & 1.40 & & & & 2.1 & & & & & & $\begin{array}{l}\text { Heary rust-colored scale on all } \\
\text { surfaces }\end{array}$ & \\
\hline T 4 & 16 & & 34.1 & 0.5430 & 0.5472 & 0.5430 & 0.0 & 1.40 & 0.00 & 0.0 & 0.0 & 2.1 & 0.00 & 0.0 & 0.0 & & & $\begin{array}{l}\text { Heavy rust-colored scale on all } \\
\text { surfaces }\end{array}$ & Clean \\
\hline T 5 & 17 & & 26.9 & 0.5364 & 0.5401 & 0.5363 & -0.1 & 1.40 & 0.006 & 0.1 & 0.1 & 2.1 & $0 ! 004$ & 0.1 & 0.1 & & & $\begin{array}{l}\text { Heavy rust-c olored scale on all } \\
\text { surfaces }\end{array}$ & Clean \\
\hline To & 19 & & 18.9 & 0.5422 & 0.5460 & 0.5422 & 0.0 & 1.40 & 0.00 & 0.0 & 0.0 & 2.1 & $0: 00$ & 0.0 & 0.0 & & & $\begin{array}{l}\text { Heavy rust-c olored scale on all } \\
\text { surfaces }\end{array}$ & Thin film on all surfaces \\
\hline T 7 & 22 & & 12.6 & 0.5348 & 0.5381 & 0.5346 & -0.2 & 1.40 & 0.01 & 0.2 & 0.2 & 2.1 & 0.01 & 0.1 & 0.1 & & & $\begin{array}{l}\text { Heavy rust-colored scale on all } \\
\text { surfaces }\end{array}$ & Thin film on all surfaces \\
\hline \multicolumn{20}{|c|}{ Corrosion Sample Coupon Holders (Zircaloy-2) } \\
\hline \multicolumn{20}{|c|}{ Core Holder } \\
\hline Part $A$ & & & 3.00 & 76.0506 & 75.9368 & & -113.8 & $\{162.0$ & $\{0.09$ & $\{1.28$ & $\{1.51$ & $\{162.0$ & $\{000$ & $\{1.28$ & $\{1.51$ & 2.00 & 2.62 & & \\
\hline Part B & & & 3.00 & 77.0787 & 76.9449 & & -133.8 & & & & ( & & 1 & & & 2.00 & 2.62 & & \\
\hline \multicolumn{20}{|c|}{ In-Line Holder } \\
\hline $\begin{array}{l}\text { Part A } \\
\text { Part B }\end{array}$ & & & & $\begin{array}{l}96.9145 \\
94.6905\end{array}$ & $\begin{array}{l}97.0823 \\
94.8652\end{array}$ & & $\begin{array}{l}+167.8 \\
+174.7\end{array}$ & $\{162.0$ & & & & $\{162.0$ & & & & & & & \\
\hline Pant B & & & & & & & & & & & & & & & & & & & \\
\hline
\end{tabular}

*Corrosion rates have been calculated both for the nominally exposed and the total specimen are as.
**Two corrosion rates are presented: one based on the total operation time of $630.3 \mathrm{hr}$ and one based on the total radiation time of $536.8 \mathrm{hr}$ ( 3 Mwhr of reactor time equivalent to $1 \mathrm{hr}$ of total radiation time). 
Table 37 (continued)

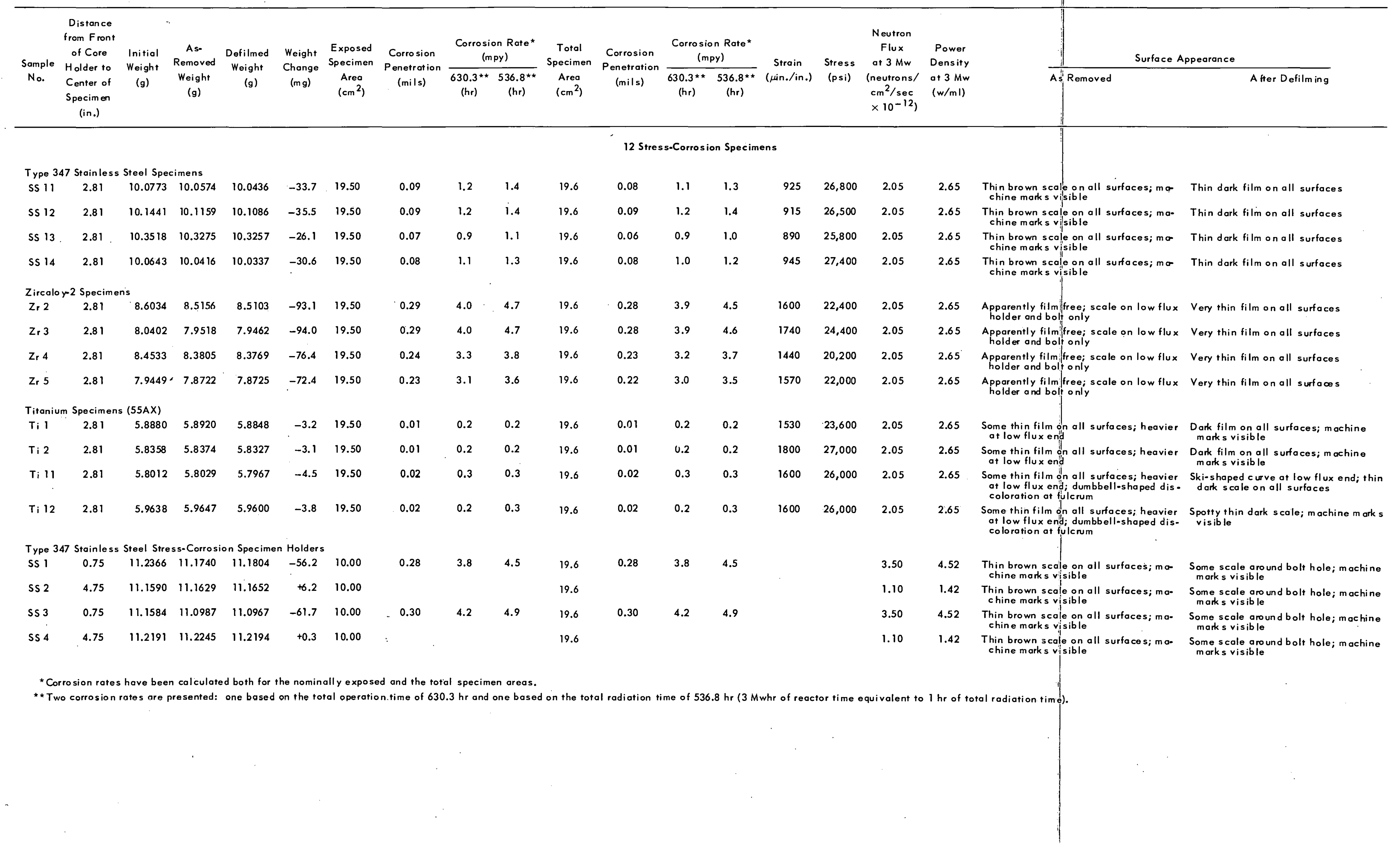




\begin{tabular}{|c|c|c|c|c|c|c|c|c|c|c|c|c|c|c|c|c|c|c|c|}
\hline \multirow{2}{*}{$\begin{array}{l}\text { Sample } \\
\text { No. }\end{array}$} & \multirow{2}{*}{$\begin{array}{c}\text { Distance } \\
\text { from Front } \\
\text { of Core } \\
\text { Holder to } \\
\text { Center of } \\
\text { Specimen } \\
\text { (in.) }\end{array}$} & \multirow{2}{*}{$\begin{array}{l}\text { Initial } \\
\text { Weight } \\
\text { (g) }\end{array}$} & \multirow{2}{*}{$\begin{array}{c}\text { As- } \\
\text { Removed } \\
\text { Weight } \\
\text { (g) }\end{array}$} & \multirow{2}{*}{$\begin{array}{c}\text { Defilmed } \\
\text { Weight } \\
(g)\end{array}$} & \multirow{2}{*}{$\begin{array}{l}\text { Weight } \\
\text { Change } \\
\text { (mg) }\end{array}$} & \multirow{2}{*}{$\begin{array}{c}\text { Exposed } \\
\text { Specimen } \\
\text { Area } \\
\left(\mathrm{cm}^{2}\right)\end{array}$} & \multirow{2}{*}{$\begin{array}{c}\text { Corrosion } \\
\text { Penetration } \\
\text { (mils) }\end{array}$} & \multicolumn{2}{|c|}{$\begin{array}{c}\text { Corrosion Rate } \\
(\text { mpy })\end{array}$} & \multirow{2}{*}{$\begin{array}{c}\text { Total } \\
\text { Specimen } \\
\text { Area } \\
\left(\mathrm{cm}^{2}\right)\end{array}$} & \multirow{2}{*}{$\begin{array}{c}\text { Corrosion } \\
\text { Penetration } \\
\text { (mils) }\end{array}$} & \multicolumn{2}{|c|}{$\begin{array}{c}\text { Corrosion Rate* } \\
\quad(m p y) ! \\
\end{array}$} & \multirow{2}{*}{$\begin{array}{c}\text { Strain } \\
(\mu \text { in. } / \text { in. })\end{array}$} & \multirow{2}{*}{$\begin{array}{c}\text { Stress } \\
(p \text { si) }\end{array}$} & \multirow{2}{*}{$\begin{array}{c}\text { Neutron } \\
\text { Flux } \\
\text { of } 3 \mathrm{Mw} \\
\text { (neutrons/ } \\
\mathrm{cm}^{2} / \mathrm{sec} \\
\times 10^{-12} \text { ) }\end{array}$} & \multirow{2}{*}{$\begin{array}{l}\text { Power } \\
\text { Density } \\
\text { of } 3 \text { Mw } \\
(w / m l)\end{array}$} & \multicolumn{2}{|c|}{ Surfoce Appearance } \\
\hline & & & & & & & & $\begin{array}{c}630.3^{\star \star} \\
(\mathrm{hr})\end{array}$ & $\begin{array}{c}536.8^{\star \star} \\
(\mathrm{hr})\end{array}$ & & & $\begin{array}{c}630.3^{* \star} \\
(\mathrm{hr})\end{array}$ & $\begin{array}{c}536.8^{\star \star} \\
(\mathrm{hr}) \\
1\end{array}$ & & & & & As Removed & After Defilming \\
\hline \multicolumn{20}{|c|}{ Zircoloy-2 Stress-Corrosion Specimen Holders } \\
\hline $\mathrm{z} 1$ & 0.75 & 9.4307 & & & & 10.00 & & & & 19.6 & & & & & & 3.50 & 4.52 & $\begin{array}{l}\text { Apporently film free; scale on low flux } \\
\text { holder and bolt only }\end{array}$ & Not defilmed \\
\hline$z_{1} 2$ & 4.75 & 8.9833 & & & & 10.00 & & & & 19.6 & & & & & & 1.10 & 1.42 & $\begin{array}{l}\text { Apporently film free; scole on low flux } \\
\text { holder and bolt only }\end{array}$ & Not defilmed \\
\hline $\mathrm{zr} 3$ & 0.75 & 9.0925 & 9.0716 & 9.0608 & -31.7 & 10.00 & 0.19 & 2.6 & 3.1 & 19.6 & 0.19 & 2.6 & 3.1 & & & 3.50 & 4.52 & $\begin{array}{l}\text { Apparently film free; scale on low flux } \\
\text { holder ond bolt only }\end{array}$ & $\begin{array}{c}\text { Thin film on all surfaces; machine } \\
\text { marks sisible }\end{array}$ \\
\hline$z_{r} 4$ & 4.75 & 8.8223 & 8.8186 & 8.8109 & -11.4 & 10.00 & 0.07 & 1.0 & 1.1 & 19.6 & 0.07 & 1.0 & 1.1 & & & 1.10 & 1.42 & $\begin{array}{l}\text { Apporently film free; scale on low flux } \\
\text { holder and bolt only }\end{array}$ & $\begin{array}{c}\text { Thin film on all surfaces; mochine } \\
\text { manks visible }\end{array}$ \\
\hline \multicolumn{20}{|c|}{ Titonium Stress-Corrosion Specimen Holders (55AX) } \\
\hline$T_{i} 1$ & 0.75 & 6.5626 & 6.5621 & 6.5591 & -3.5 & 10.00 & 0.03 & 0.4 & 0.5 & 19.6 & 0.03 & 0.4 & 0,5 & & & 3.50 & 4.52 & $\begin{array}{l}\text { Some thin film on all surfaces; heavier } \\
\text { at low flux end }\end{array}$ & $\begin{array}{l}\text { Beveled edges rough; flat surfaces } \\
\text { cle an }\end{array}$ \\
\hline$T i 2$ & 4.75 & 0.6108 & 6.6145 & 6.6103 & -0.5 & 10.00 & 0.01 & 0.1 & 0.1 & 19.6 & 0.004 & 0.1 & 0.1 & & & 1.10 & 1.42 & $\begin{array}{l}\text { Some thin film on all surfoces; heavier } \\
\text { at low flux end }\end{array}$ & $\begin{array}{l}\text { Beveled edges rough; flat surfaces } \\
\text { clean; some film oround hole }\end{array}$ \\
\hline$T_{i} 3$ & 0.75 & 6.4948 & 6.4919 & 6.4907 & -4.1 & 10.00 & 0.04 & 0.5 & 0.6 & 19.6 & 0.04 & 0.5 & 0.6 & & & 3.50 & 4.52 & $\begin{array}{l}\text { Some thin film on all surfoces; heavier } \\
\text { at low flux end; dumbbell-s hioped dis. } \\
\text { coloration of fulcrum }\end{array}$ & $\begin{array}{l}\text { Beveled edges sough flat surfaces } \\
\text { clean; some film around hole }\end{array}$ \\
\hline$T_{i} 8$ & 4.75 & 6.4321 & 6.4362 & 6.4320 & -0.1 & 10.00 & 0.001 & 0.01 & 0.02 & 19.6 & 0.001 & 0.01 & 0.02 & & & 1.10 & 1.42 & $\begin{array}{l}\text { Some thin film on all surfoces; heavier } \\
\text { at low flux end; dumbbelleshoped dis. } \\
\text { coloration af fulcrum }\end{array}$ & $\begin{array}{l}\text { Beveled edges rough; flat surfaces } \\
\text { clean; some film around hole }\end{array}$ \\
\hline
\end{tabular}

* Corro sion rates have been calculated both for the nominally exposed and the total specimen areas.

** Two corrosion rates are presented: one based on the total operation time of $630.3 \mathrm{hr}$ and one ba sed on the total radiation time of $536.8 \mathrm{hr}$ ( 3 Mwhr of reactor time equivalent to $1 \mathrm{hr}$ of total radiation time). 
Table 38. Corrosion Data for Zircaloy-2 Corrosion Specimens for Loop FF

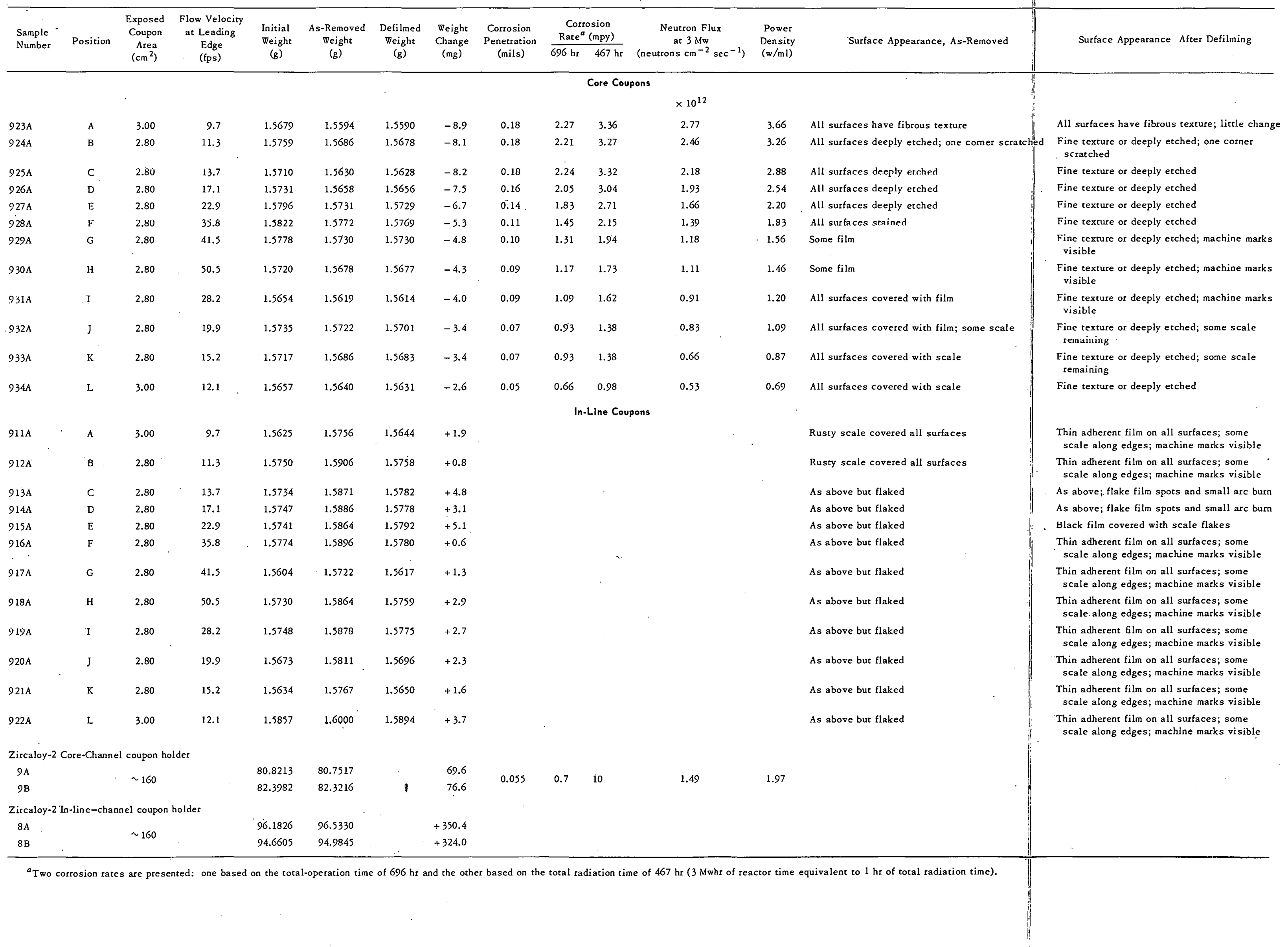


Table 39. Corrosion Data for Zircaloy-2 Corrosion Specimens for Loop GG

\begin{tabular}{|c|c|c|c|c|c|c|c|c|c|c|c|c|c|c|}
\hline \multirow{2}{*}{$\begin{array}{l}\text { Sample } \\
\text { Number }\end{array}$} & \multirow{2}{*}{ Position } & \multirow{2}{*}{$\begin{array}{l}\text { Exposed } \\
\text { Coupon } \\
\text { Area } \\
\left(\mathrm{cm}^{2}\right)\end{array}$} & \multirow{2}{*}{$\begin{array}{l}\text { Flow Velocity } \\
\text { at Leading } \\
\text { Edge } \\
\text { (fps) }\end{array}$} & \multirow{2}{*}{$\begin{array}{l}\text { Initial } \\
\text { Weight } \\
\text { (g) }\end{array}$} & \multirow{2}{*}{$\begin{array}{l}\text { As-Removed } \\
\text { Weight } \\
(\mathrm{g})\end{array}$} & \multirow{2}{*}{$\begin{array}{l}\text { Defilmed } \\
\text { Weight } \\
\text { (g) }\end{array}$} & \multirow{2}{*}{$\begin{array}{l}\text { Weight } \\
\text { Change } \\
\text { (mg) }\end{array}$} & \multirow{2}{*}{$\begin{array}{l}\text { Corrosion } \\
\text { Penetration } \\
(\text { mil) }\end{array}$} & \multicolumn{2}{|c|}{$\begin{array}{r}\text { Corrosion } \\
\operatorname{Rate}^{a} \text { (mpy) } \\
\end{array}$} & \multirow{2}{*}{$\begin{array}{c}\text { Neutron Flux } \\
\text { at } 3 \mathrm{Mm}^{\mathrm{m}} \\
\text { (neutrons } \mathrm{cm}^{-2} \sec ^{-1} \text { ) }\end{array}$} & \multirow{2}{*}{$\begin{array}{c}\text { Power } \\
\text { Density } \\
(\mathrm{w} / \mathrm{ml})\end{array}$} & \multirow{2}{*}{ Surface Appearance, As-Removed } & \multirow{2}{*}{ Surface Appearance, After Defilming } \\
\hline & & & & & & & & & $1064 \mathrm{hr}$ & $897 \mathrm{hr}$ & & & & \\
\hline \multicolumn{15}{|c|}{ Core Coupons } \\
\hline & & & & & & & & & & & $\times 10^{12}$ & & & \\
\hline $947 \mathrm{~A}$ & A & 3.00 & 10.7 & 1.5730 & 1.5564 & 1.5561 & -16.9 & 0.341 & 2.80 & 3.32 & 3.62 & 4.83 & Etched surface covered with thin flaky scale & Dull etched appearance \\
\hline $948 \mathrm{~A}$ & B & 2.80 & 12.5 & 1.5691 & 1.5532 & 1.5526 & -16.5 & 0.357 & 2.93 & 3.48 & 3.34 & 4.45 & Ftched surface covered with thin flaky scale & Dull etched appearance \\
\hline $949 \mathrm{~A}$ & c & 2.80 & 15.1 & 1.5723 & 1.5570 & 1.5562 & -16.1 & 0.348 & 2.86 & 3.39 & 3.05 & 4.07 & Etched surface covered with thin flaky scale & Dull etched appearance \\
\hline $950 \mathrm{~A}$ & D & 2.80 & 18.9 & 1.5750 & 1.5609 & 1.5600 & -15.0 & 0.324 & 2.66 & 3.15 & 2.55 & 3.40 & Etched surface covered with thin flaky scale & Dull etched appearance \\
\hline $951 \mathrm{~A}$ & E & 2.80 & 25.3 & 1.5735 & 1.5604 & 1.5594 & -14.1 & 0.305 & 2.50 & 2.97 & 2.29 & 3.05 & $\begin{array}{l}\text { Lightly etched surface covered with thin } \\
\text { flaky scale }\end{array}$ & Dull lightly etched appearance \\
\hline $952 \mathrm{~A}$ & $\mathrm{~F}$ & 2.80 & 39.5 & 1.5724 & 1.5601 & 1.5594 & -13.0 & 0.281 & 2.31 & 2.74 & 2.17 & 2.89 & $\begin{array}{l}\text { Lightly etched surface covered with thin } \\
\text { flaky scale }\end{array}$ & Dull lightly etched appearance \\
\hline $953 \mathrm{~A}$ & G & 2.80 & 45.8 & 1.5576 & 1.5472 & 1.5458 & -11.8 & 0.255 & 2.09 & 2.48 & 1.88 & 2.51 & $\begin{array}{l}\text { Faint machine marks in areas where scale } \\
\text { has not been retained }\end{array}$ & $\begin{array}{l}\text { Faint machine marks; lightly etched ap- } \\
\text { pearance; some very thin film visible }\end{array}$ \\
\hline $954 \mathrm{~A}$ & H & 2.80 & 55.7 & 1.5778 & 1.5694 & 1.5668 & -11.0 & 0.238 & 1.95 & 2.32 & 1.60 & 2.13 & Heavy flaky scale; machine marks visible & $\begin{array}{l}\text { Faint machine marks; lightly etched ap. } \\
\text { pearance; some very thin film visible }\end{array}$ \\
\hline $955 \mathrm{~A}$ & I & 2.80 & 31.1 & 1.5582 & 1.5492 & 1.5476 & -10.6 & 0.229 & 1.88 & 2.23 & 1.40 & 1.87 & $\begin{array}{l}\text { Some scale along clamping edges; machine } \\
\text { marks visible }\end{array}$ & $\begin{array}{l}\text { Faint machine marks; very lightly etched } \\
\text { appearance }\end{array}$ \\
\hline $956 \mathrm{~A}$ & J & 2.80 & 22.0 & 1.5804 & 1.5720 & 1.5719 & -8.5 & 0.184 & 1.51 & 1.79 & 1.25 & 1.67 & Thin scale on all surfaces & Machine marks visible \\
\hline $957 \mathrm{~A}$ & $\mathrm{~K}$ & 2.80 & 16.8 & 1.5810 & 1.5735 & 1.5717 & -9.3 & 0.201 & 1.65 & 1.96 & 1.12 & 1.50 & Scale on all surfaces & Machine marks visible \\
\hline $958 \mathrm{~A}$ & L & 2.80 & 13.4 & 1.5726 & 1.5658 & 1.5648 & -7.8 & 0.157 & 1.29 & 1.53 & 1.00 & 1.33 & Thin scale on all surfaces & Machine marks visible \\
\hline \multicolumn{15}{|c|}{ In-Line Coupons } \\
\hline 935A & A & 3.00 & 10.7 & 1.5733 & 1.6035 & 1.5744 & +1.1 & & & & & & $\begin{array}{l}\text { All surfaces covered with a heavy brown } \\
\text { rustlike scale }\end{array}$ & $\begin{array}{l}\text { Film on all surfaces; some seale retained } \\
\text { particularly along edges }\end{array}$ \\
\hline $936 \mathrm{~A}$ & B & 2.80 & 12.5 & 1.5820 & 1.6080 & 1.5837 & +1.7 & & & & & & $\begin{array}{l}\text { All surfaces covered with a heavy brown } \\
\text { rustlike scale }\end{array}$ & $\begin{array}{l}\text { Film on all surfaces; some scale retained } \\
\text { particularly along edges }\end{array}$ \\
\hline $937 \mathrm{~A}$ & c & 2.80 & 15.1 & 1.5800 & 1.6034 & 1.5814 & +1.4 & & & & & & $\begin{array}{l}\text { All surfaces covered with a heavy brown } \\
\text { rustlike scale }\end{array}$ & $\begin{array}{l}\text { Film on all surfaces; some scale retained } \\
\text { particularly along edges }\end{array}$ \\
\hline $938 \mathrm{~A}$ & D & 2.80 & 18.9 & 1.5760 & 1.5982 & 1.5780 & +2.0 & & & & & & $\begin{array}{l}\text { All surfaces covered with a heavy brown } \\
\text { rustlike scale }\end{array}$ & $\begin{array}{l}\text { Film on all surfaces; some scale retained } \\
\text { particularly along edges }\end{array}$ \\
\hline $939 \mathrm{~A}$ & E & 2.80 & 25.3 & 1.5817 & 1.6013 & 1.5840 & +2.3 & & & & & & $\begin{array}{l}\text { All surfaces covered with a heavy brown } \\
\text { rustlike scale }\end{array}$ & $\begin{array}{l}\text { Film on all surfaces; some scale retained } \\
\text { particularly along edges }\end{array}$ \\
\hline $940 \mathrm{~A}$ & F & 2.80 & 39.5 & 1.5800 & 1.5996 & 1.5818 & +1.8 & & & & & & $\begin{array}{l}\text { All surfaces covered with a heavy brown } \\
\text { rustlike scale }\end{array}$ & $\begin{array}{l}\text { Film on all surfaces; some scale retained } \\
\text { particularly aloug edges }\end{array}$ \\
\hline $941 \mathrm{~A}$ & G & 2.80 & 45.8 & 1.5842 & 1.6010 & 1.5858 & +1.6 & & & & & & $\begin{array}{l}\text { All surfaces covered with a heavy brown } \\
\text { rustlike scale }\end{array}$ & $\begin{array}{l}\text { Film on all surfaces; some scale retained } \\
\text { particularly along edges }\end{array}$ \\
\hline $942 \mathrm{~A}$ & H & 2.80 & 55.7 & 1.5735 & 1.5928 & 1.5755 & +2.0 & & & & & & $\begin{array}{l}\text { All surfaces covered with a heavy brown } \\
\text { rustlike scale }\end{array}$ & $\begin{array}{l}\text { Film on all surfaces; some scale retained } \\
\text { particularly along edges }\end{array}$ \\
\hline $943 \mathrm{~A}$ & I & 2.80 & 31.1 & 1.5737 & 1.5923 & 1.5756 & +1.9 & $\cdot$ & & & & & $\begin{array}{l}\text { All surfaces covered with a heavy brown } \\
\text { rustlike scale }\end{array}$ & $\begin{array}{l}\text { Film on all surfaces; some scale retained } \\
\text { particularly along edges }\end{array}$ \\
\hline $944 \mathrm{~A}$ & $\mathrm{~J}$ & 2.80 & 22.0 & 1.5843 & 1.5985 & 1.5829 & -1.4 & 0.030 & 0.25 & 0.29 & & & $\begin{array}{l}\text { All surfaces covered with a heavy brown } \\
\text { rustlike scale }\end{array}$ & $\begin{array}{l}\text { Film on all surfaces; some scale retained } \\
\text { particularly along edges }\end{array}$ \\
\hline $945 \mathrm{~A}$ & K & 2.80 & 16.8 & 1.5573 & 1.5708 & 1.5548 & -2.5 & 0.054 & 0.44 & 0.53 & & & $\begin{array}{l}\text { All surfaces covered with a heavy brown } \\
\text { rustlike scale }\end{array}$ & $\begin{array}{l}\text { Film on all surfaces; some scale retained } \\
\text { particularly along edges }\end{array}$ \\
\hline $946 \mathrm{~A}$ & L & 3.00 & 13.4 & 1.5787 & 1.6004 & 1.5790 & +0.3 & & & & & & $\begin{array}{l}\text { All surfaces covered with a heavy brown } \\
\text { rustlike scale }\end{array}$ & $\begin{array}{l}\text { Film on all surfaces; some scale retained } \\
\text { parzicularly along edges }\end{array}$ \\
\hline \multicolumn{15}{|c|}{ Zircaloy-2 Core-channel coupon holder No. 17} \\
\hline & $\begin{array}{l}\text { A } \\
\text { B }\end{array}$ & 160 & & $\begin{array}{l}82.5112 \\
80.5849\end{array}$ & $\begin{array}{l}82.2520 \\
80.2151\end{array}$ & & $\begin{array}{l}-259.2 \\
-369.8\end{array}$ & 0.24 & 1.95 & 2.32 & 2.06 & 2.75 & & - \\
\hline \multicolumn{15}{|c|}{ Zircaloy-2 In-line-channel coupon holder No. 16} \\
\hline & A & 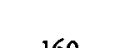 & & 93.8427 & 94.1495 & & +306.8 & & & & & & & \\
\hline & B & 100 & & 94.8266 & 95.0172 & & +190.6 & & & & & & & \\
\hline
\end{tabular}

${ }^{a}$ Two corrosion rates are presented: one based on the total operation time of $1064 \mathrm{hr}$ and the other based on the total radiation of $897 \mathrm{hr}(3$ Mwhr of reactor time equivalent to $1 \mathrm{hr}$ of total radiation time). 


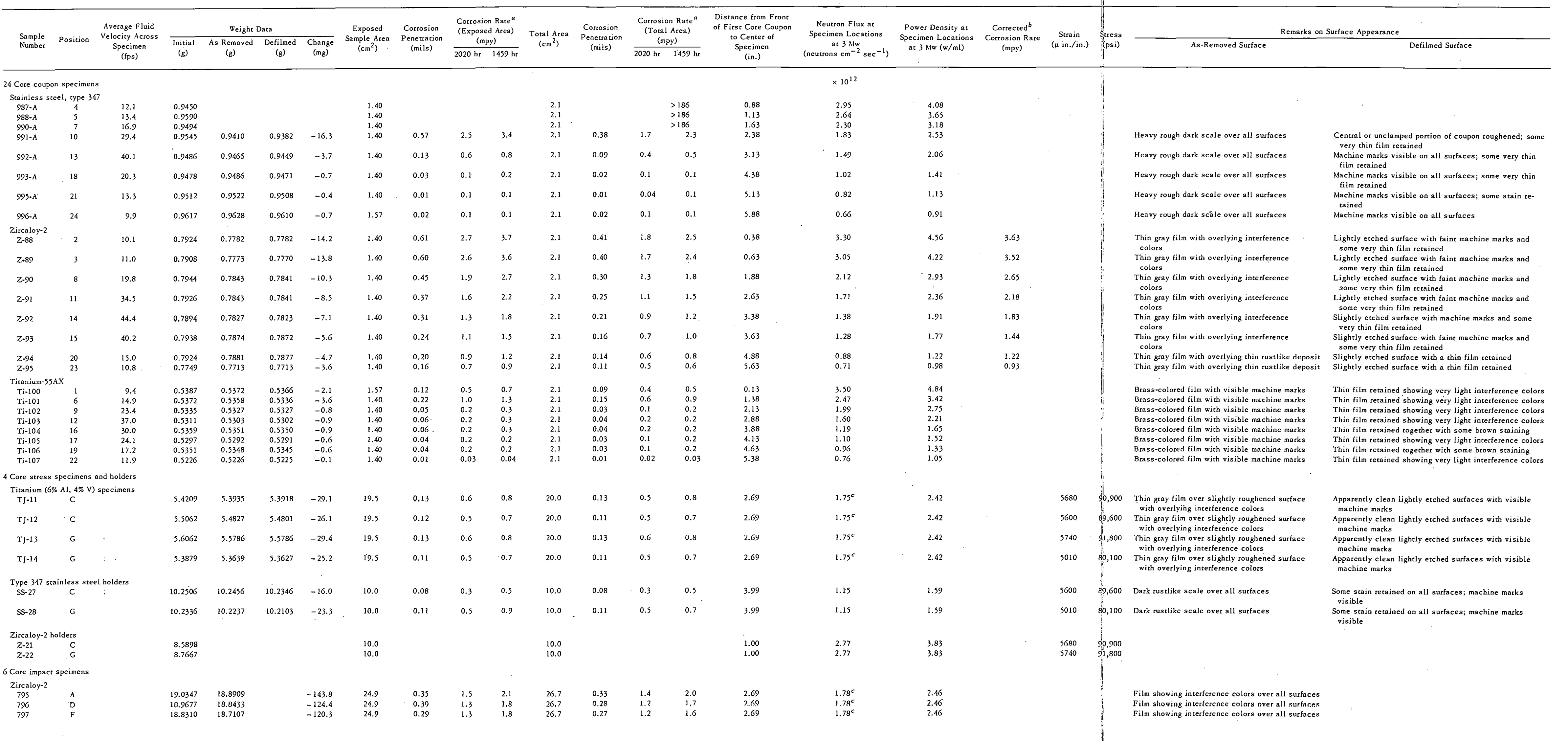




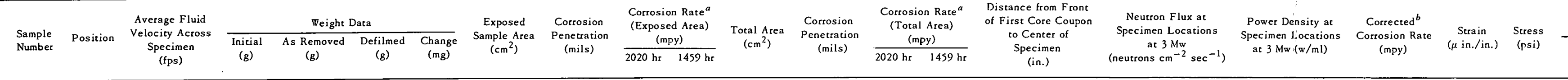

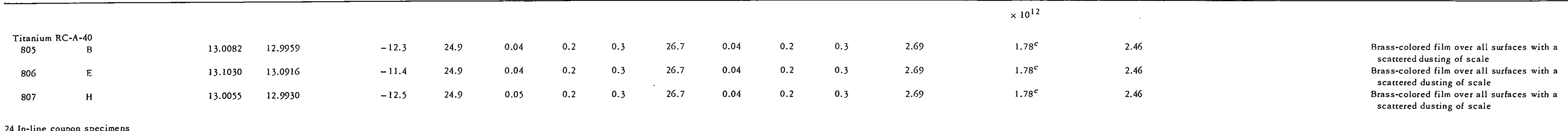

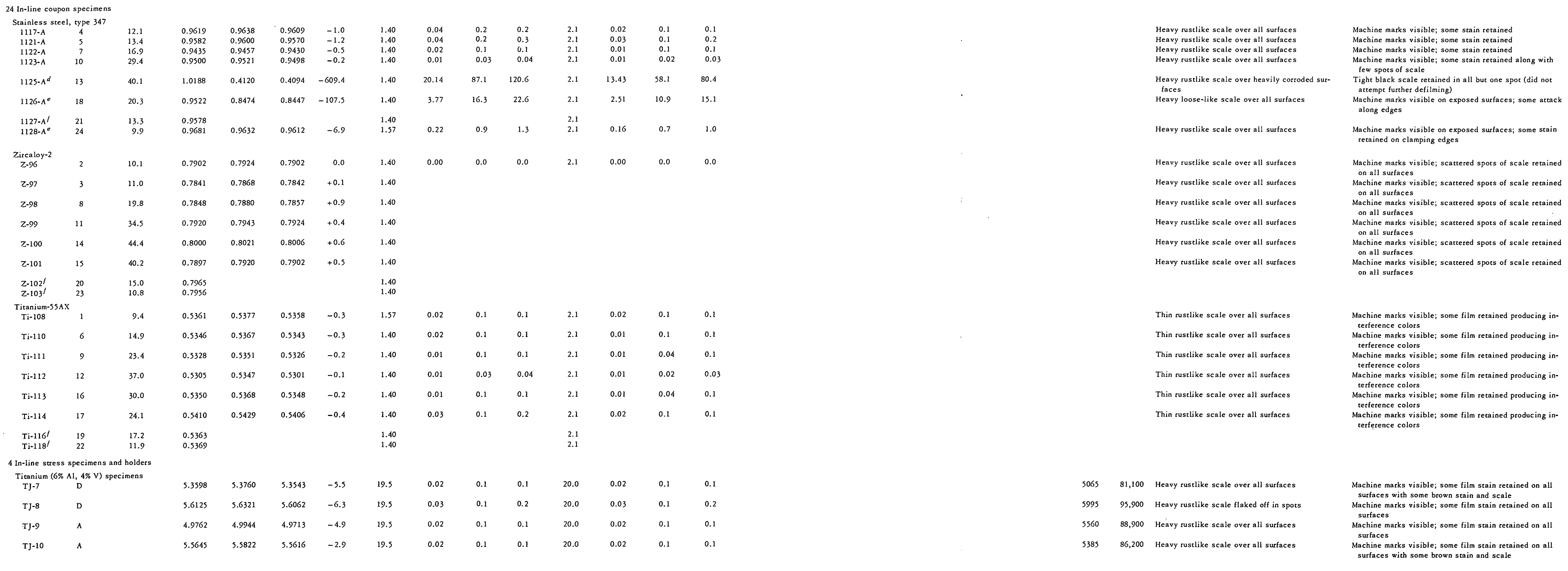




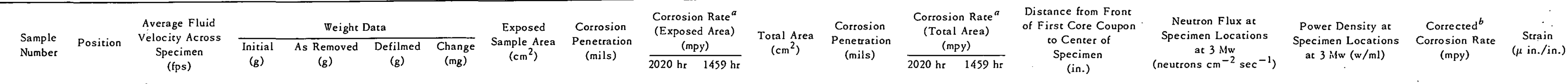

Stainless steel, type 347 holders
sS-25

Ss-26 A

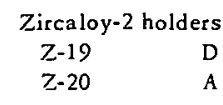

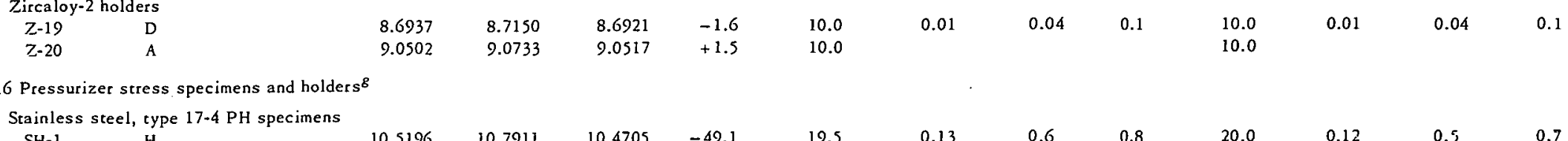

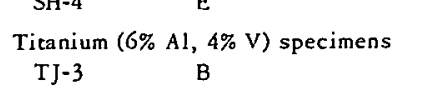

$\begin{array}{lllllll}\text { TJ-4 } & \text { B } & 5.3617 & 5.3617 & 5.3623 & +0.4 & \\ \text { T. } & 5.5618 & 5.5618 & 5.5553 & -6.5 & 1.55\end{array}$

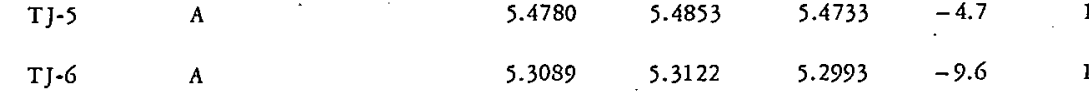

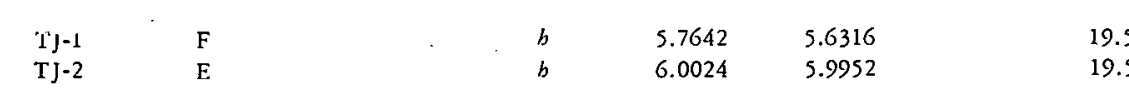

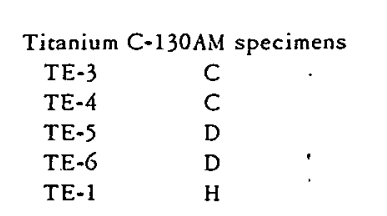

TE-2

Stainless strel, eve 347 holders
sS-23

SS-24

ss-21.

Ss-22

Zircaloy-2 holde
$Z=17$
$Z-18$
$Z-23$

$\underset{\substack{\text { Z-24 } \\ \text { Titannium RC-70 holders } \\ \text { Ti-20 }}}{\mathrm{C}}$

Ti-41

Ti-21

Ti:-22

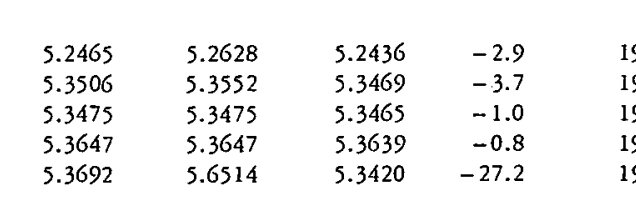

$\begin{array}{llllll}5.5978 & 5.6007 & 5.5970 & -0.8 & 1.5\end{array}$

$\begin{array}{lllll}10.4985 & -10.5379 & 10.4861 & -12.4 & 10.0\end{array}$

$\begin{array}{llllll}10.0260 & 10.6303 & 10.6213 & -4.7 & 10.0\end{array}$

$\begin{array}{lllll}10.5334 & 10.6022 & 10.4431 & -90.3 & 10.0\end{array}$

$\begin{array}{llll}10.4101 & 10.4319 & 10.4005 & -36\end{array}$

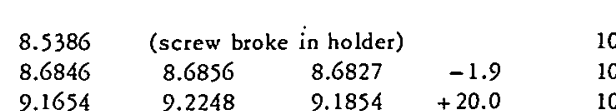

$\begin{array}{llllll}8.9567 & 8.9831 & 8.9817 & +25.0 & 100\end{array}$

$\begin{array}{llllll}5.4843 & 5.4882 & 5.4826 & -1.7 & 100\end{array}$

$\begin{array}{lllll}6.1564 & 6.1601 & 6.1566 & +0.2 & 100\end{array}$

$\begin{array}{lllll}5.6335 & 5.6594 & 5.6510 & -2.5 & 100\end{array}$

$\begin{array}{llll}5.8157 & 5.8526 & 5.8068 & -8.9\end{array}$

$\begin{array}{lllll}0.3991 & 6.5589 & 6.3743 & -4.8\end{array}$

$\begin{array}{lllllll}0.13 & 0.6 & 0.8 & 20.0 & 0.12 & 0.5 & 0.7\end{array}$

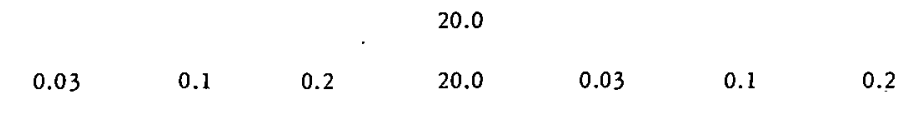

$\begin{array}{lllllll}0.02 & 0.1 & 0.1 & 20.0 & 0.02 & 0.1 & 0.1 \\ 0.04 & 0.2 & 0.3 & 20.0 & 0.04 & 0.2 & 0.3\end{array}$

20.0
20.0

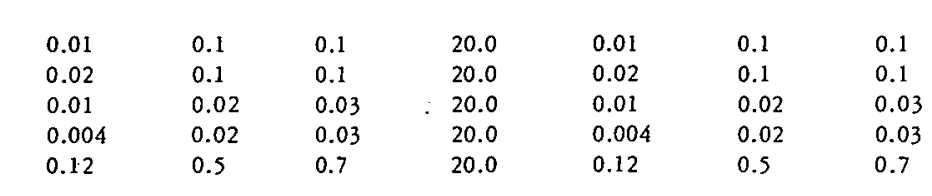

$\begin{array}{lll}0.03 & 20.0 & 0.04\end{array}$

$\begin{array}{lllllll}0.06 & 0.3 & 0.4 & 10.0 & 0.06 & 0.3 & 0.3\end{array}$

$\begin{array}{lllllll}0.02 & 0.1 & 0.1 & 10.0 & 0.02 & 0.1 & 0.1\end{array}$

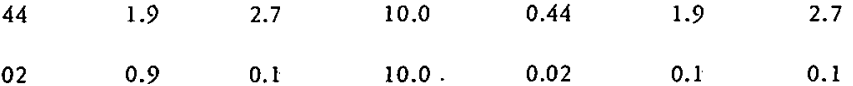

$\begin{array}{lllllll}0.02 & 0.1 & 0.1 & 10.0 & 0.02 & 0.1 & 0.1\end{array}$

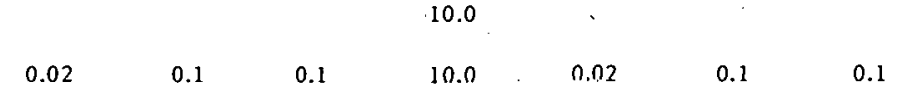

$\begin{array}{lllllll}0.08 & 0.4 & 0.5 & 10.0 & 0.08 & 0.3 & 0.5\end{array}$

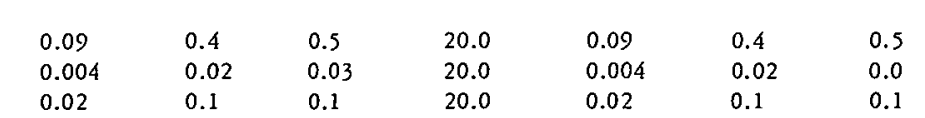

5995

5065

2750
2550
2700

4875

5363

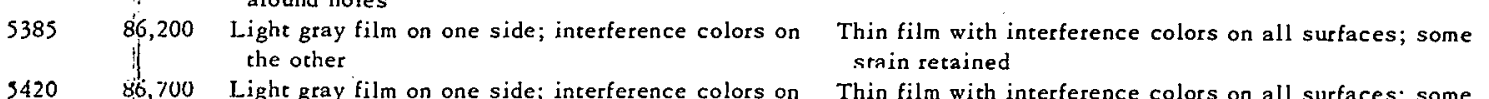

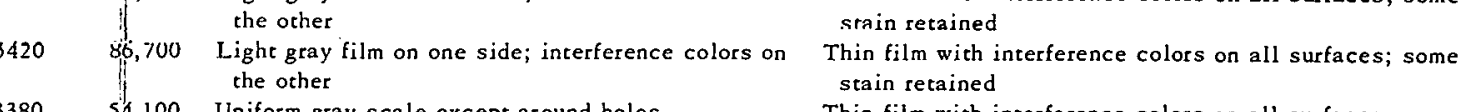

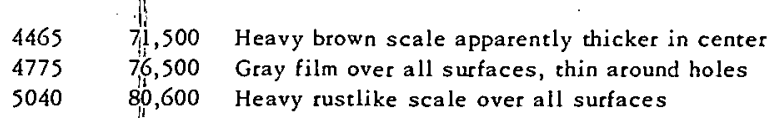

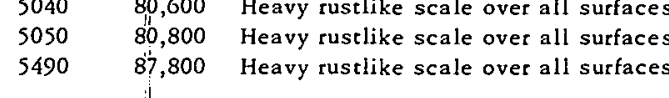

4940

(3)

5420

2550

2700

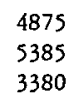

3380

32.55

4465
4775

5040

5050

549 p,000 Thin gray film with incerference colors on all sur-

800 Heavy dark rustilike scale over all surfaces

700 Heavy dark rustilike scale over all surfaces :-

Heavy dark rustlike scale over all surfaces

Hoo Heavy dark rustlike scale over all surfaces

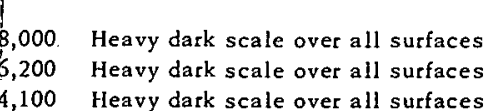

100 Hcavy dark scale over all surfaces

.500 Heavy dark scale over all surfaces

600 Heavy dark scale over all surfaces

800 Heavy dark scale over all surfaces

, s00 Heavy usstilike scale except around screw hol
Clean merallic surfaces with machine marks; some scale Clean metallic surfaces with machine marks; some scale

Some film retained with scartered spots of scale

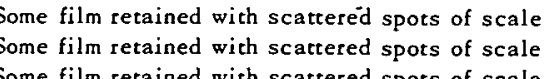

Darkgay film retained on all surfaces Thin film with interference colors on all surfaces
Thin filit wivh interference colors on all surfaces; some
spots of scale retained

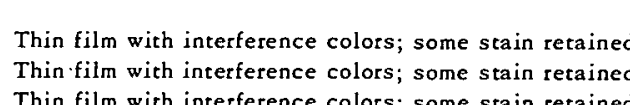

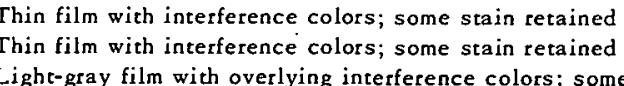

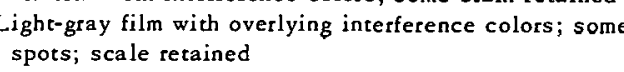

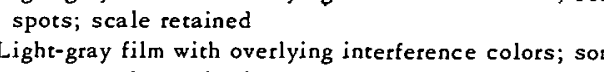

Apparentyly clean surfaces vith machine marks visible;
same scatereed spots of stain

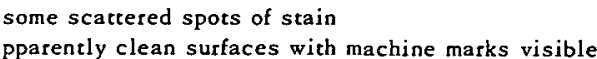
some scattered spots of stain Were suripped in disassembly
apoarently clean surfaces wijh

Thin black film retained on all surfaces
Thin film on one side and heayy rustlike scale recained on the other Rustlike scale retained on all surfaces

Thin film retained on all surfaces; machine marks Thin film reeained on all surfaces; machine marks visible; some spots of scale
Thin film rearinedon all suffaces, visibile; some spots of scale
Thin film rectined on all

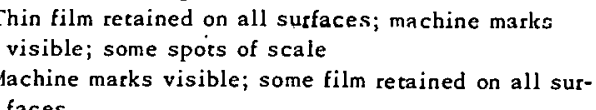

Thin adherent black film over all surfaces
Thin adherent black film over all surfaces 
Table 40 (continued)

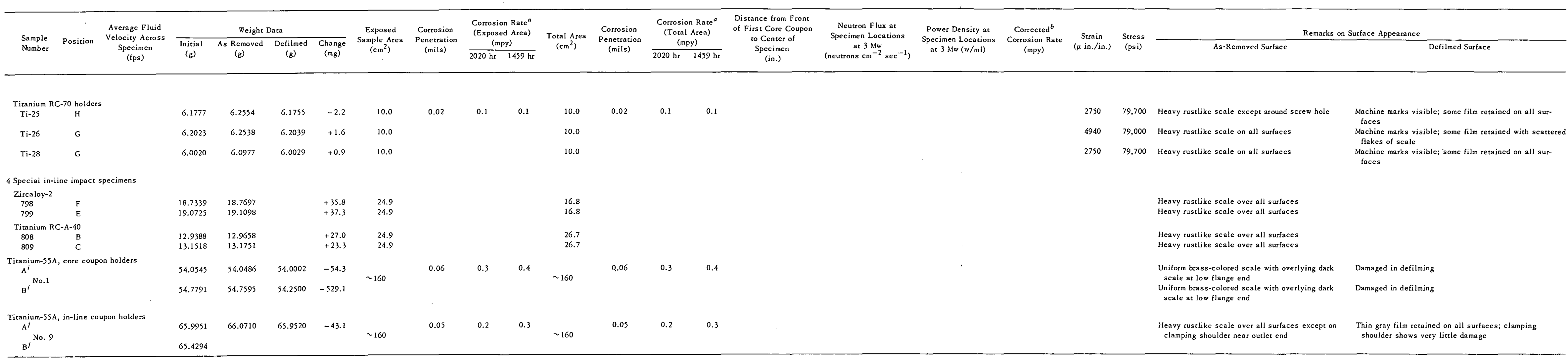

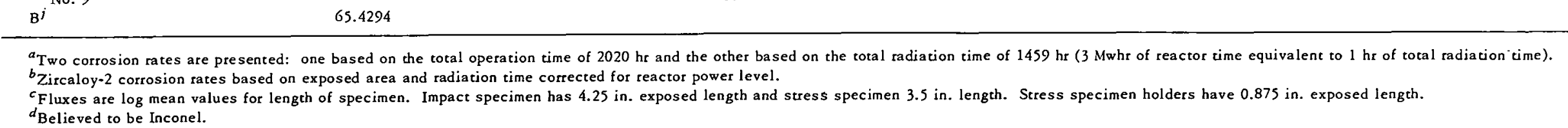

$e_{\text {Adjacent to loose coupons. }}$

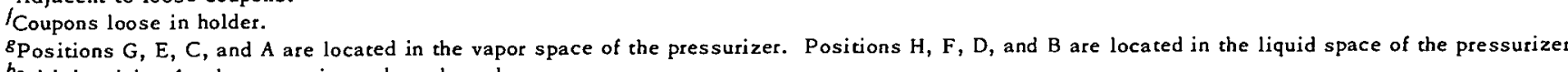

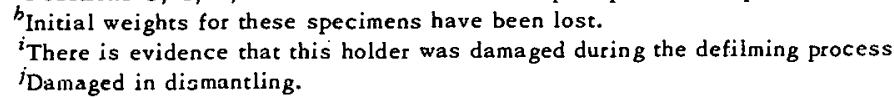




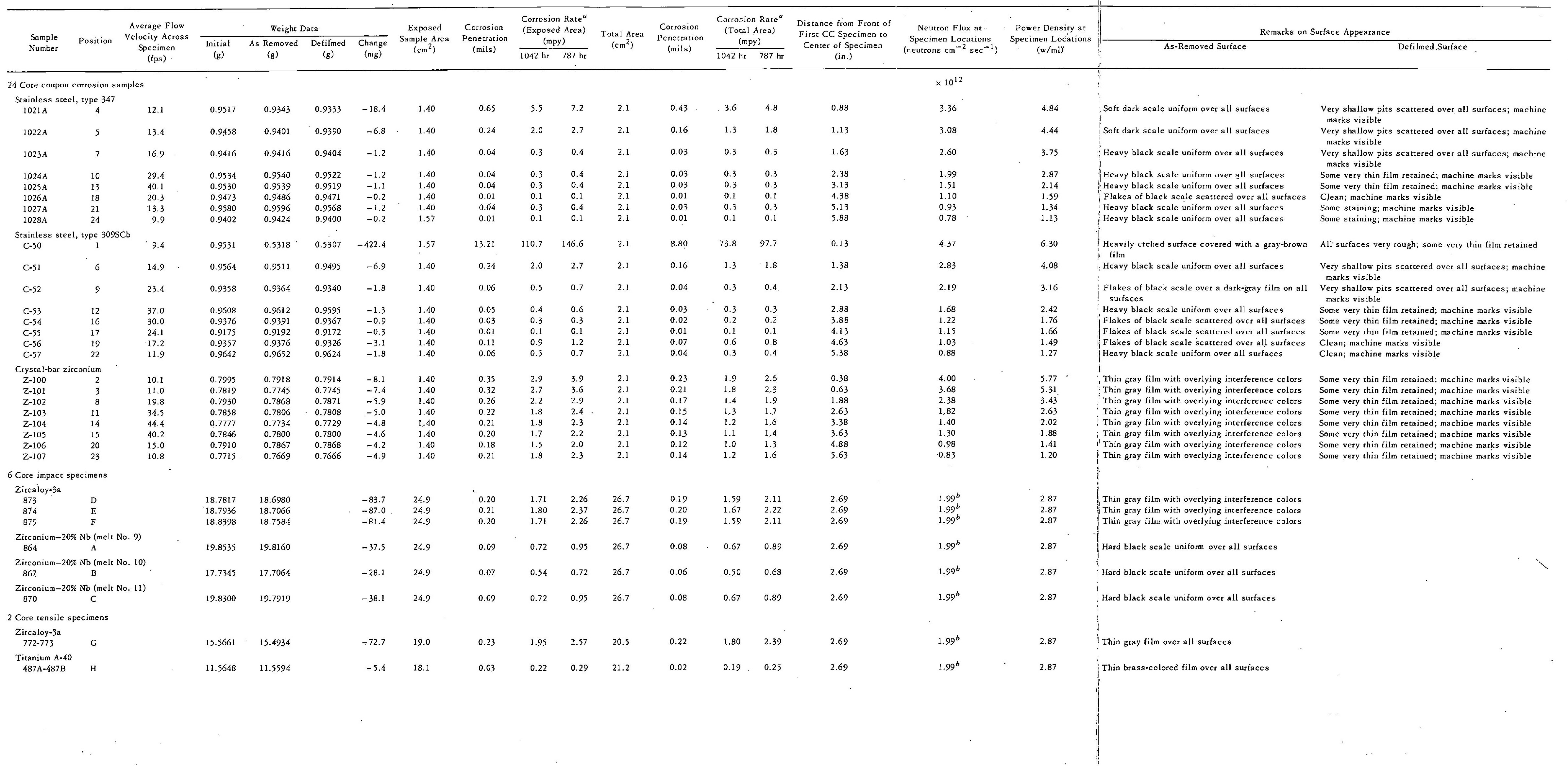




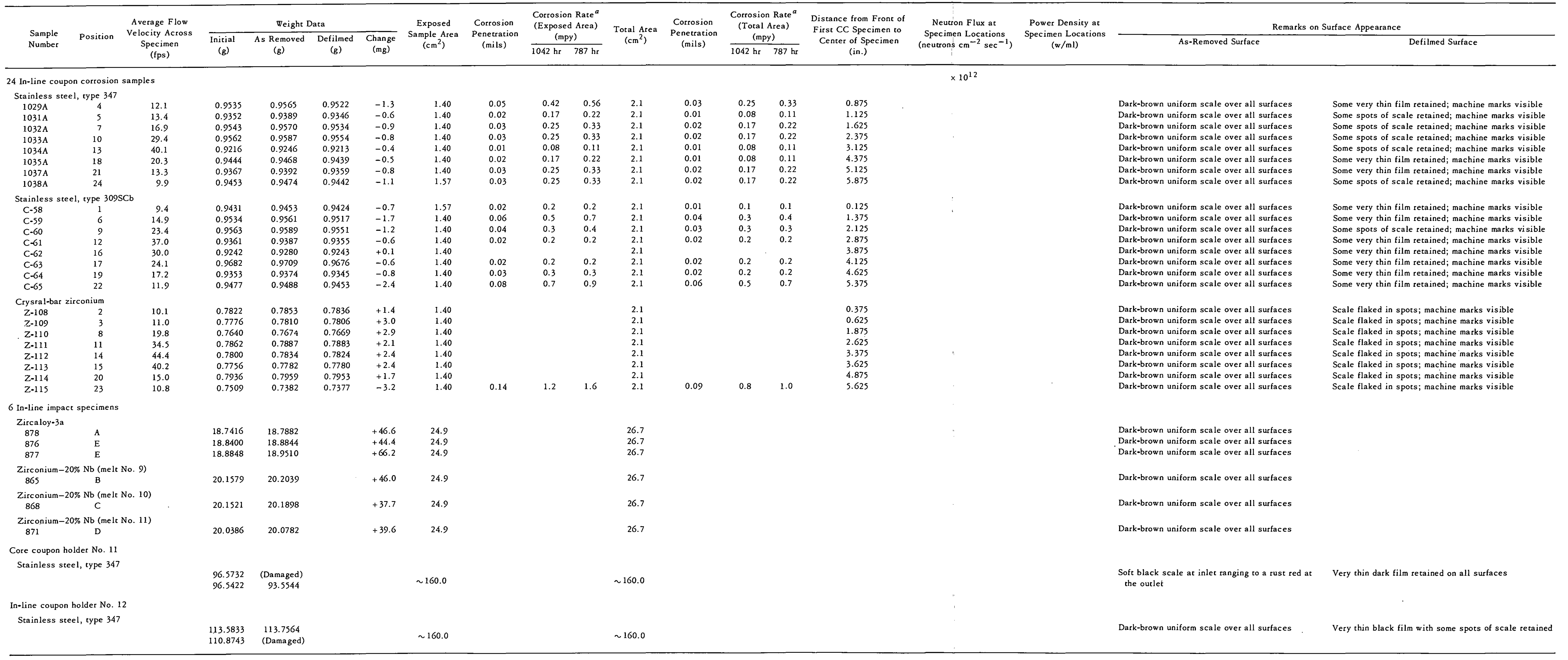

$a_{\text {TWo corrosion rates are presenced: one based }}$
$b_{\text {Log mean }}$ value for exposed length of specimen. 


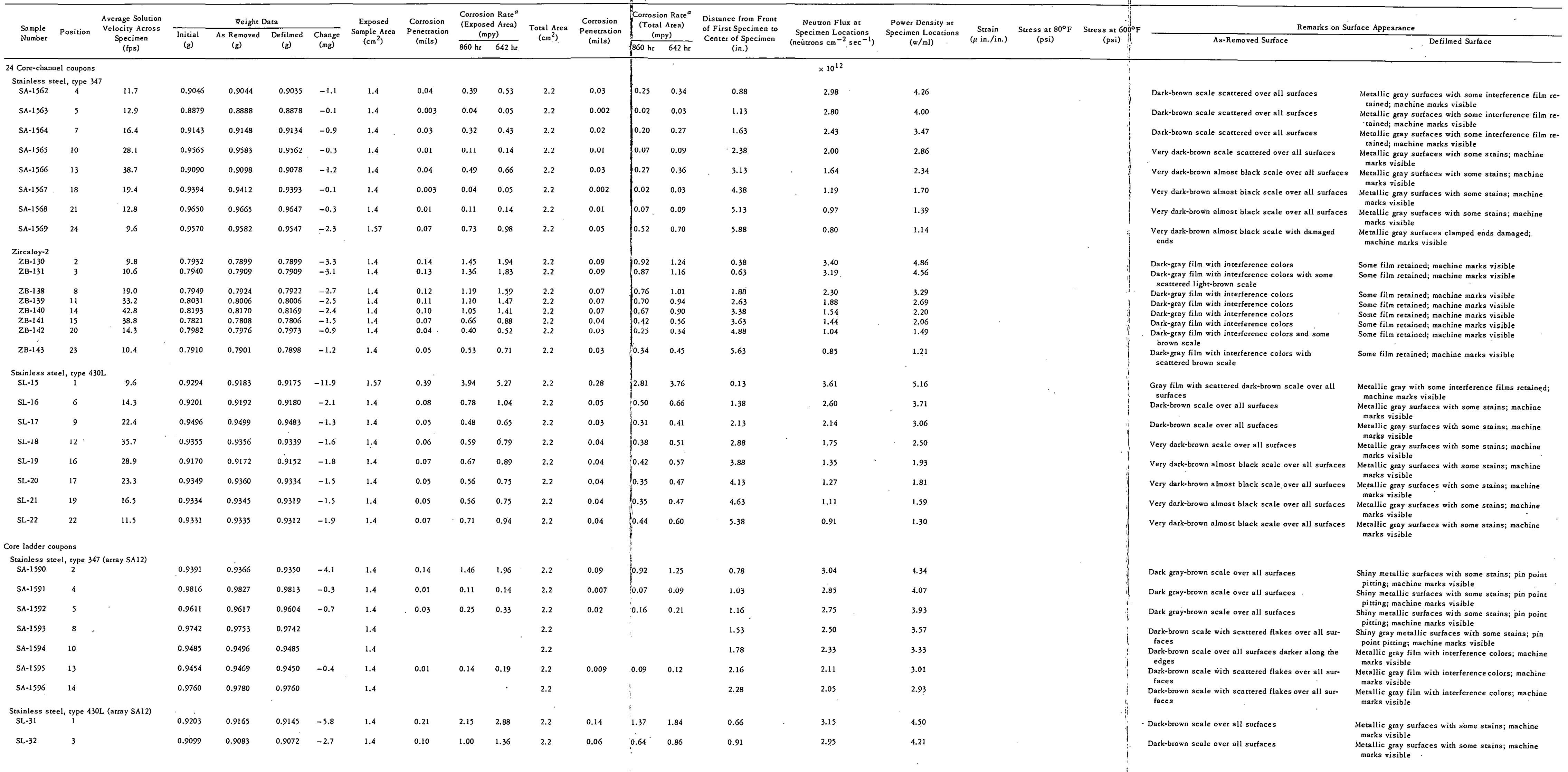


Table 42 (continued)

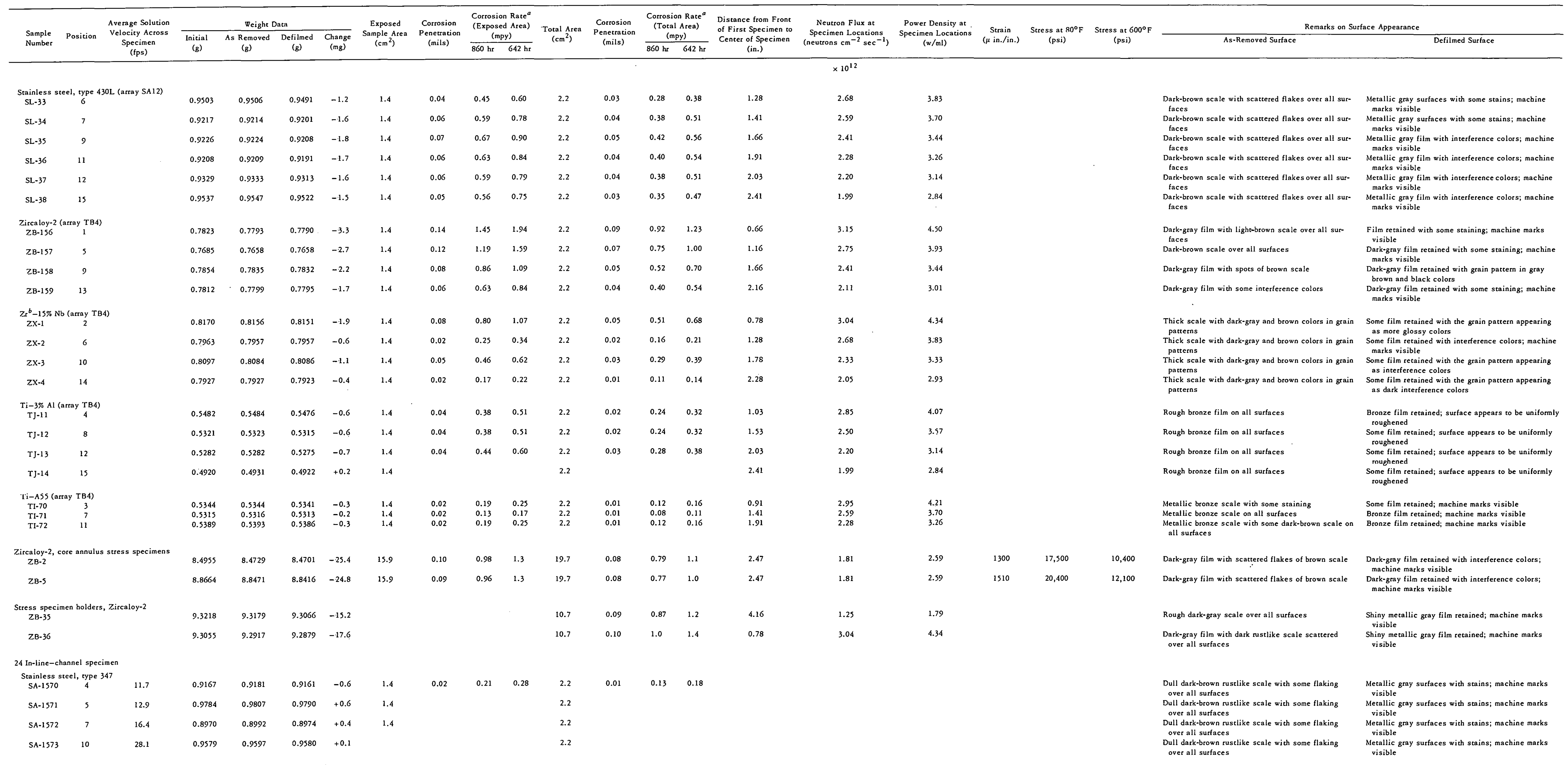




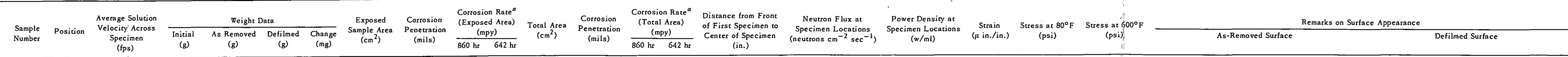

\begin{tabular}{|c|c|c|c|c|c|c|c|c|c|c|c|c|c|c|}
\hline 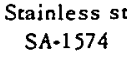 & 1. yype 347 & 38.7 & 0.9327 & 0.0343 & 0.0325 & -0.2 & 1.4 & 0.01 & 0.07 & 0.12 & 2.2 & 0.01 & 0.05 & 0.06 \\
\hline SA-157S & 18 & 19.4 & 0.9123 & 0.9138 & 0,9122 & -0.1 & 1.4 & 0.004 & 0.04 & 0.05 & 2.2 & 0.002 & 0.02 & 0.03 \\
\hline SA-1576 & 21 & 12.8 & 0.0223 & 0.9306 & 0.2291 & -0.2 & 1.4 & 0.01 & 0.07 & 0.10 & 2.2 & 0.01 & 0.05 & 0.06 \\
\hline SA-1577 & 24 & 9.6 & 0.9566 & 0.0559 & 0.0338 & -2.8 & 1.57 & 0.09 & 0.89 & 1.19 & 2.2 & 0.06 & 0.57 & 0.76 \\
\hline 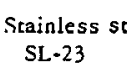 & 1. yype 430 & 0.6 & 0.9420 & 0.9438 & 0.9404 & -1.6 & 1.57 & 0.05 & 0.33 & 0.71 & 2.2 & 0.03 & 0.31 & \\
\hline SL-24 & 6 & 14.3 & 0.9237 & 0.9240 & 0.9215 & -2.2 & 1.4 & 0.08 & 0.82 & 1.09 & 2.2 & 0.05 & 0.52 & 0.70 \\
\hline SL-25 & 9 & 22.4 & 0.9191 & 0.9193 & 0.9170 & -2.1 & 1.4 & 0.08 & 0.78 & 1.04 & 2.2 & 0.05 & 0.50 & 0.66 \\
\hline $\mathrm{SL}-26$ & 12 & 35.7 & 0.9882 & 0.9492 & 0.9460 & -2.2 & 1.4 & 0.08 & 0.82 & 1.09 & 2.2 & 0.05 & 0.52 & 0.70 \\
\hline SL-27 & 16 & 28.9 & 0.9250 & 0.9256 & 0.9231 & -1.9 & 1.4 & 0.07 & 0.70 & 0.94 & 2.2 & 0.04 & 0.45 & 0.60 \\
\hline SL-28 & 17 & 23.3 & 0.9378 & 0.9389 & 0.9362 & -1.6 & 1.4 & 0.06 & 0.59 & 0.79 & 2.2 & 0.04 & 0.38 & 0.51 \\
\hline SL-29 & 19 & 16.5 & 0.9392 & 0.9402 & 0.9376 & -1.6 & 1.4 & 0.06 & 0.59 & 0.79 & 2.2 & 0.04 & 0.38 & 0.51 \\
\hline SL-30 & 22 & 11.5 & 0.8983 & 0.8995 & 0.8850 & -2.3 & 1.4 & 0.08 & 0.85 & 1.14 & 2.2 & 0.05 & 0.54 & 0.73 \\
\hline 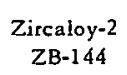 & 2 & 9.8 & 0.7942 & 0.7964 & 0.7960 & +1.8 & 1.4 & & & & 2.2 & & & \\
\hline $2 \mathrm{~B}-145$ & 3 & 10.6 & 0.8108 & 0.8124 & 0.8120 & +1.2 & 1.4 & & & & 2.2 & & & \\
\hline $\mathrm{ZB}-146$ & 8 & 19.0 & 0.7935 & 0.7961 & 0.7960 & +2.5 & 1.4 & & & & 2.2 & & & \\
\hline$z B-147$ & 11 & 33.2 & 0.8010 & 0.8026 & 0.8026 & +1.6 & 1.4 & & & & 2.2 & & & \\
\hline ZB-148 & 14 & 42.8 & 0.7865 & 0.7892 & 0.7890 & +2.5 & 1.4 & & & & 2.2 & & & \\
\hline ZB-149 & 15 & 38.8 & 0.7870 & 0.7896 & 0.7895 & +2.5 & 1.4 & & & & 2.2 & & & $\therefore$ \\
\hline$z B-150$ & 20 & 14.3 & 0.7787 & 0.7809 & 0.7807 & +2.0 & 1.4 & & & & 2.2 & & & \\
\hline$z B-151$ & 23 & 10.4 & 0.7926 & 0.7946 & 0.7940 & +1.4 & 1.4 & & & & 2.2 & & & \\
\hline \multicolumn{15}{|c|}{ n-line ladder coupons. } \\
\hline $\begin{array}{l}\text { Satininess s } \\
\text { sAl-1597 }\end{array}$ & $\frac{1}{2}$ & & 0.9740 & 0.9760 & 0.9774 & +0.4 & 1.4 & & & & 2.2. & & & \\
\hline SA-1598 & 4 & & 0.0489 & 0.9500 & 0.9488 & -0.1 & 1.4 & 0.004 & 0.04 & 0.05 & 2.2. & 0.002 & 0.02 & 0.03 \\
\hline SA-1599 & s & & 0.9157 & 0.9164 & 0.9154 & -0.3 & 1.4 & 0.01 & 0.11 & 0.14 & 2.2 & 0.01 & 0.07 & 0.09 \\
\hline SA-1600 & 8 & & 0.9306 & 0.9316 & 0.9303 & -0.3 & 1.4 & 0.01 & 0.11 & 0.14 & 2.2 & 0.01 & 0.07 & 0.09 \\
\hline SA-1601 & 10 & & 0.9820 & 0.9837 & 0.9875 & +0.5 & 1.4 & & & & 2.2 & & & \\
\hline SA-1602 & $133^{\circ}$ & & 0.9704 & 0.9719 & 0.9707 & +0.3 & 1.4 & & & & 2.2. & & & \\
\hline SA-1603 & 14 & & 0.9724 & 0.9741 & 0.9727 & +0.3 & 1.4 & & & & 2.2 & & & \\
\hline \multicolumn{3}{|l|}{ S- } & 0.9360 & 0.9364 & 0.0339 & -2.1 & 1.4 & 0.08 & 0.78 & 1.04 & 2.2 & 0.05 & 0.50 & 0.66 \\
\hline SL-10 & 3 & & 0.9289 & 0.9289 & 0.2251 & -3.8 & 1.4 & 0.14 & 1.41 & 1.89 & 2.2 & 0.09 & 0.90 & 1.20 \\
\hline SL-41 & 6 & & 0.9106 & 0.9104 & 0.0089 & -1.7 & 1.4 & 0.06 & 0.63 & 0.84 & 2.2 & 0.04 & 0.40 & \\
\hline
\end{tabular}

Dull dark-brown nusclike scale with some flaking
over all surfaces

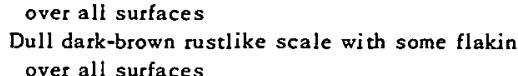

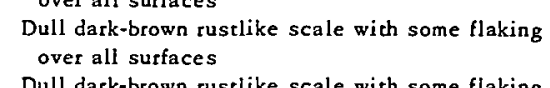
Dull dark s-rown nurstike scale with some flaking
over all surfaces Dull dark-boronn rustlike scale with some flaking
over all surfaces
Dull dark-brown nustike scale with some flaking over all surfaces
Dull dark-brown nustlike scale with some flaking Dull dark-brown nustilike scale with some flaking over all surfaces over all surfaces Dull dark-brown nustihe scalt wh some flaking
over all surfaces Dull dark-browa rustlike scale with some flaking
over all surfaces

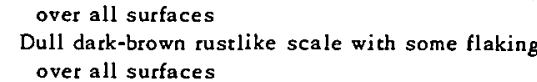
Dull dark-brown rustike scale with some flaking
over all surfaces over all surtaces
Duul dark-brown nustlike scale with some flaktiog Dutl dark-brown nusclike scale with some flaking Dull dark-browown russtike scale with some flaking over all surfaces
Dull dark-brown rustlike scale with some flaking Dver all surfaces Dull dark-bil suftaces
over al surfaces over all surfaces Dull dark-brown nustrike scale with some flaking
over all surfaces

Dull dark-brown scale beriec on the adeses Dull dark-brown sate hy Div Dull dark-brown scale heavier on the edges Dull dark-brown scale heavier on the edges Dull dark-brown scale heavier in spors

Dull dark-brown scale heavier on the edgess Dull dark-brown scale heavier on the edges Dark-gray film with scattered areas of dark-brow
scale

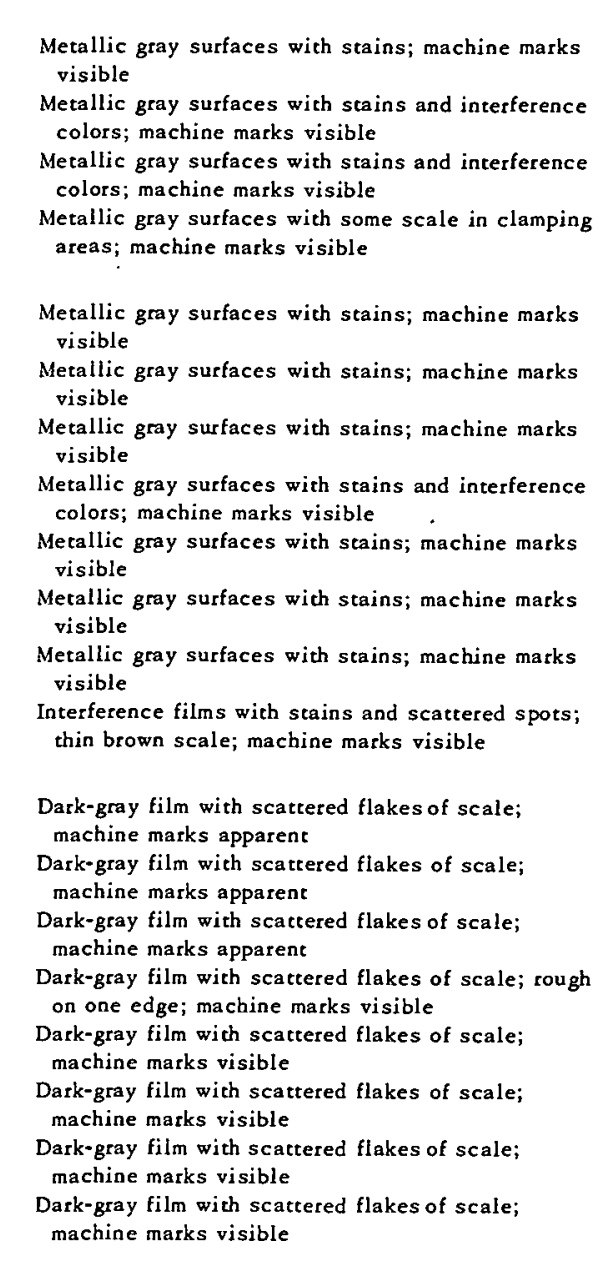

Mecallic gray surfaces with stains; machine marks Metallic gary surfaces with stains, machine marks Metalile gray surfaces with sains; machine marks
visible Metallic gray surfaces with stains; machine makks
visisle Metallic gray surfaces with stains; machine marh Merallic grat surfaces with stains; machine marks
visibie Metallicic gray surfaces.wiih stains; machine marks Metallic ray surfaces with stains; machine marks
visible Merallic gray surfaces with stains; machine marks viserible
Mealic gray surfaces with stains; machine marks
visible 


\begin{tabular}{|c|c|c|c|c|c|c|c|c|c|c|c|c|c|c|c|c|c|c|c|c|c|c|c|}
\hline \multirow[b]{2}{*}{ 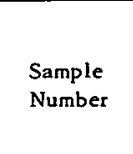 } & \multirow[b]{2}{*}{ Positioń } & \multirow{2}{*}{ 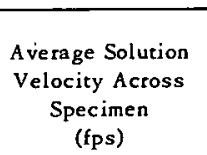 } & \multirow[b]{2}{*}{$\begin{array}{c}\text { Inicial } \\
(\mathrm{g})\end{array}$} & \multirow{2}{*}{\multicolumn{2}{|c|}{$\begin{array}{l}\text { Weight Data } \\
\text { As Removed Defilined }\end{array}$}} & \multirow{2}{*}{ 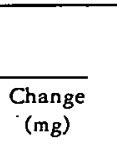 } & \multirow{2}{*}{ 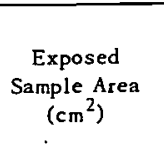 } & \multirow{2}{*}{$\begin{array}{l}\text { Corrosion } \\
\text { Penteration } \\
\text { (mils) }\end{array}$} & \multirow{2}{*}{\multicolumn{2}{|c|}{$\begin{array}{l}\text { Corosion Ratea } \\
\text { (Exposed Atreas) } \\
\text { (mpy) }\end{array}$}} & \multirow{2}{*}{$\begin{array}{c}\text { Total Afrea } \\
\left(\mathrm{cm}^{2}\right)^{-}\end{array}$} & \multirow{2}{*}{$\begin{array}{l}\text { Corirsion } \\
\text { Penerataion } \\
\text { (mils) }\end{array}$} & \multirow{2}{*}{\multicolumn{2}{|c|}{ 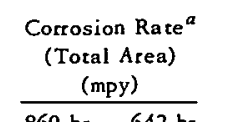 }} & \multirow{2}{*}{ 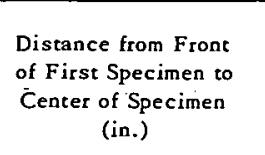 } & \multirow{2}{*}{ 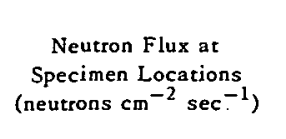 } & \multirow{2}{*}{ 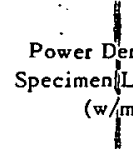 } & \multirow{2}{*}{ 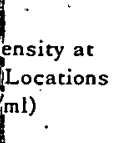 } & \multirow{2}{*}{ 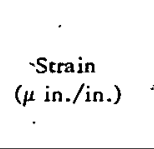 } & \multirow{2}{*}{ 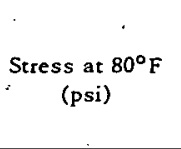 } & \multirow{2}{*}{$\begin{array}{l}\text { Stress at G000 } \\
(\text { (psi) }\end{array}$} & \multicolumn{2}{|c|}{ Remarks on Surtace Appearance. } \\
\hline & & & & & & & & & & & & & & & & & & & & & & As-Removed Sufface & Defilmed Surface \\
\hline & & & & & & & & & & & & & & & & $\times 10^{12}$ & & & & & & & \\
\hline $\begin{array}{l}\text { Stainless st } \\
\text { sLl-42 }\end{array}$ & teel, type 4 & 30. (aray SA13) & 0.9134 & 0.9134 . & 0.9116 & -1.8 & 1.4 & 0.07 & 0.67 & 0.89 & 2.2 & 0.04 & 0.43 & 0.57 & & & & & & & & Dark-gray Film with scatceed areas of dark-brown & Meatlicic gry surfaces with stains; machine marks \\
\hline SL-43 & , & & 0.9374 & 0.9374 & 0.9354 & -2.0 & 1.4 & 0.07 & 0.74 & 0.99 & 2.2 & 0.05 & 0.47 & 0.63 & & & & & & & & $\begin{array}{l}\text { sace } \\
\text { Uniform dark-gray scale on all surfaces }\end{array}$ & $\begin{array}{l}\text { Disible } \\
\text { Merallic gray surfaces with stains; machine marks }\end{array}$ \\
\hline SL-44 & 11 & & 0.9160 & 0.9156 & 0.9139 & -2.1 & 1.4 & 0.08 & 0.78 & 1.04 & 2.2 & 0.05 & 0.50 & 0.66 & & & & & & & & Dull dark-brown scale heavier on the edges & $\begin{array}{l}\text { Misible } \\
\text { Metallic gray surfaces with staiass; machine marks }\end{array}$ \\
\hline SL-45 & 12 & & 0.9315 & 0.9317 & 0.9269 & -4.6 & 1.4 & 0.17 & 1.71 & 2.28 & 2.2 & 0.11 & 1.09 & 1.45 & & & & & & & & Dull dark-brown scale heavier on the edges & 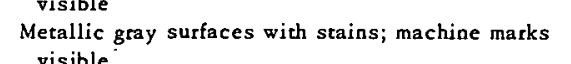 \\
\hline SL-46 & 15 & & 0.9287 & 0.9289 & 0.9270 & -1.7 & 1.4 & 0.06 & 0.63 & 0.84 & 2.2 & 0.04 & 0.40 & 0.54 & & & & & & & & Dull dark-brown scale heavier in spors & 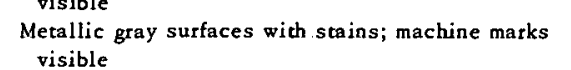 \\
\hline $\begin{array}{c}\text { Zircaly-y-2. } \\
\text { zB-100. }\end{array}$ & (aray & & 0.7924 & 0.7964 & 0.7942 & +1.8 & 1.4 & & & & 2.2 & & & & & & & & & & & Heary dark shiny scale with rough surfaces & Dark-gray film with scartered flakes of brown scale; \\
\hline zB-161 & s & & 0.7823 & 0.7861 & 0.7840 & +1.7 & 1.4 & & & & $2.2^{\circ}$ & & & & & & & & & & & Heavy dark shiny scale with rough. surfaces & 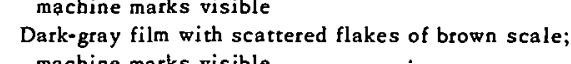 \\
\hline zB-162 & 9 & & 0.7649 & 0.7688 & 0.7605 & +1.6 & 1.4. & & & & 2.2 & & & & & & & & & & & Heavy dark shiny scale with rough surfaces & 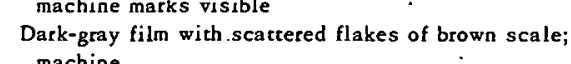 \\
\hline $28-163$ & 13 & & 0.7689 & 0.7714 & 0.7704 & +1.5 & 1.4 & & & & 2.2 & & & & & & & & & & & Heavy dark shiny scale with rough surfaces & 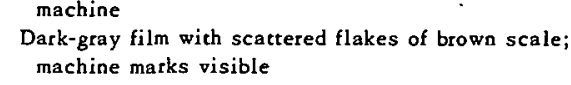 \\
\hline 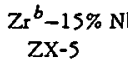 & $\stackrel{2 \text { aratay }}{2}$ & & 0.8096 & 0.8126 & 0.8103 & +0.7 & 1.4 & & & & 2.2 & & & & & & & & & & & Heavy dark shiny scale with rough surfaces & Dark-gray film with spots of brown scale in grain \\
\hline $2 x-6$ & 6 & & 0.8136 & 0.8155 & 0.8143 & +0.7 & 1.4 & & & & 2.2 & & & & & & & & & & & Heavy dark shiny scale with rough.surfaces & 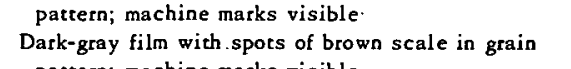 \\
\hline $\mathrm{zx}-7$ & 10 & & 0.8045 & 0.8064 & 0.8053 & +0.8 & 1.4 & & & & 2.2 & & & & & & & & & & & Dark scale witha g granula partern & 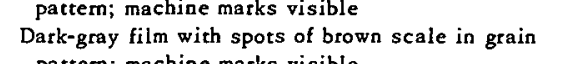 \\
\hline $2 x-8$ & ${ }^{14}$ & & 0.7882 & 0.7899 & 0.7894 & +1.2 & 1.4 & & & & 2.2 & & & & & & & & & & & Dark scale with a granular patern & 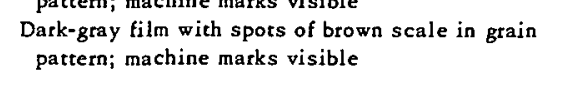 \\
\hline 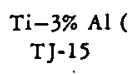 & (array r rB2) & & 0.5475 & 0.5499 & 0.5476 & +0.1 & 1.4 & & & & 2.2 & & & & & & & & & & & Heary bronze scale with spots of shiny dark rough & Shiny bronze surfaces sith rough surffaces and inter \\
\hline $\mathrm{TJ}-16$ & 8 & & 0.5352 & 0.5375 & 0.5352 & 0.0 & 1.4 & 0.0 & 0.0 & 0.0 & 2.2 & 0.0 & 0.0 & 0.0 & & & & & & & & $\begin{array}{l}\text { surfaces } \\
\text { Heavy bronze scale with spots of shiny dark rough }\end{array}$ & 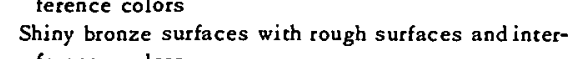 \\
\hline TJ-17 & i2 & & 0.5603 & $0.5625^{\circ}$ & 0.5600 & +0.3 & 1.4 & & & & & & & & & & & & & & & $\begin{array}{l}\text { surfaces } \\
\text { Heavy brone scale with spots of shiny dark rough }\end{array}$ & $\begin{array}{l}\text { terence colers } \\
\text { Shiny bronze surfaces with rough h. surfaces and inter }\end{array}$ \\
\hline $\mathrm{TJ}-18$ & is & & 0.5423 & 0.5428 & 0.5422 & -0.1 & 1.4 & 0.01 & 0.01 & 0.01 & 2.2 & 0.01 & 0.01 & .0 .01 & & & & & & & & 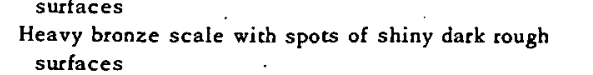 & 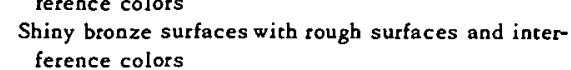 \\
\hline 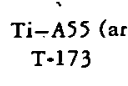 & $\begin{array}{l}\text { tay } \mathrm{TB} 2 \mathrm{C} \\
3\end{array}$ & & 0.5333 & 0.5378 & 0.5335 & +0.2 & 1.4 & & & & 2.2 & & & & & & & & & & & Heavy dark shiny scale with rough surfaces & 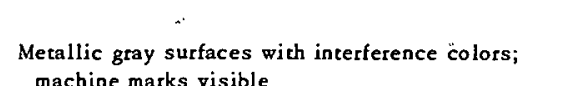 \\
\hline $\mathrm{T}-174$ & 7 & & 0.5373 & 0.5387 & 0.5374 & +0.1 & 1.4 & & & & 2.2 & & & & & & & & & & & Heary bronze-colored scale & 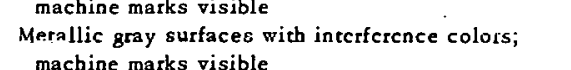 \\
\hline$r-175$ & 11 & & 0.5428 & 0.5444 & 0.5430 & +0.2 & & & & & 2.2 & & & & & & & & & & & Heavy bronze-colored scale & 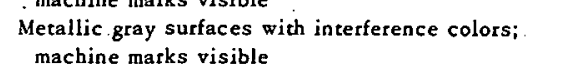 \\
\hline ircess specin & men (in-line & & & & & & & & & & & & & & & & & & & & & & \\
\hline $\begin{array}{l}\text { Ziticalog-2.2. } \\
z B \cdot 6\end{array}$ & scess spec & & 8.4771 & 8.4867 & 8.4833 & +6.2 & 15.9 & & & & 19.7 & & & & & & & & 1300 & 17,500 & 10,400 & Uniform dark-brown scale over all surfaces & 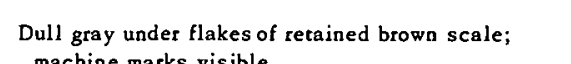 \\
\hline zB-9 & & & 8.4198 & 8.4286 & 8.4262 & +6.4 & 15.9 & & & & 19.7 & & & & & & & & 1305 & 17,500 & 10,400 & Uniform dark-brown scale over all surfaces & 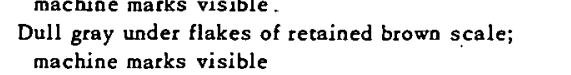 \\
\hline $\begin{array}{c}\text { Seress spec } \\
\text { ZB-37 }\end{array}$ & cimen bolde & $s$, Zircaloy-2 & 9.2006 & 9.2040 & 9.2016 & +1.0 & & & & & 10.7 & & & & & & & & & & & Very dark nustilike scale scattered over all. surfaces & Dull gray under flakes of feceained brown scale; \\
\hline $28-38$ & & & 9.3038 & 9.3131 & 9.3100 & +6.2 & & & & & 10.7 & & & & & & & & & & & Very dark nustilike scale scatererd over all surfaces & 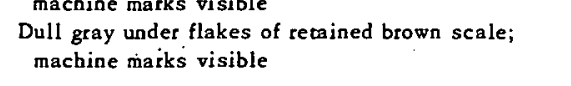 \\
\hline $\begin{array}{l}\text { Satinless ste } \\
\substack{A \\
B}\end{array}$ & eel, type 34 & , corec-chanel coup & 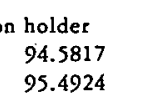 & 94.4873 & 94.4176 & 164.1 & $\sim 160$ & 0.10 & 1.0 & 1.4 & $\sim 160$ & 0.10 & 1.0 & 1.4 & 3.0 & 1.9 & 2. 2.7 & & & & & $\begin{array}{l}\text { Mecallicic gray to dark gray; scale on one end; pitting } \\
\text { on ocher }\end{array}$ & $\begin{array}{l}\text { Metallic gray scale with a darker gray where bands } \\
\text { clamped holder }\end{array}$ \\
\hline $\begin{array}{l}\text { Stainless } \\
\text { A } \\
\text { B }\end{array}$ & eel, yye 34 & 1, in-line-channel c c & $\begin{array}{l}\text { upon holder } \\
\text { 113.5865 } \\
113.3152\end{array}$ & 113.5790 & 113.5326 & 54.0 & $\sim 160$ & 0.03 & 0.3 & 0.5 & $\sim 160$ & 0.03 & 0.3 & 0.5 & & & & & & & & Dark-brown scale tanging to a nss-colored scale & $\begin{array}{l}\text { Parches of dark-bibown to rus-red scale; scattered } \\
\text { gray underlay. }\end{array}$ \\
\hline
\end{tabular}




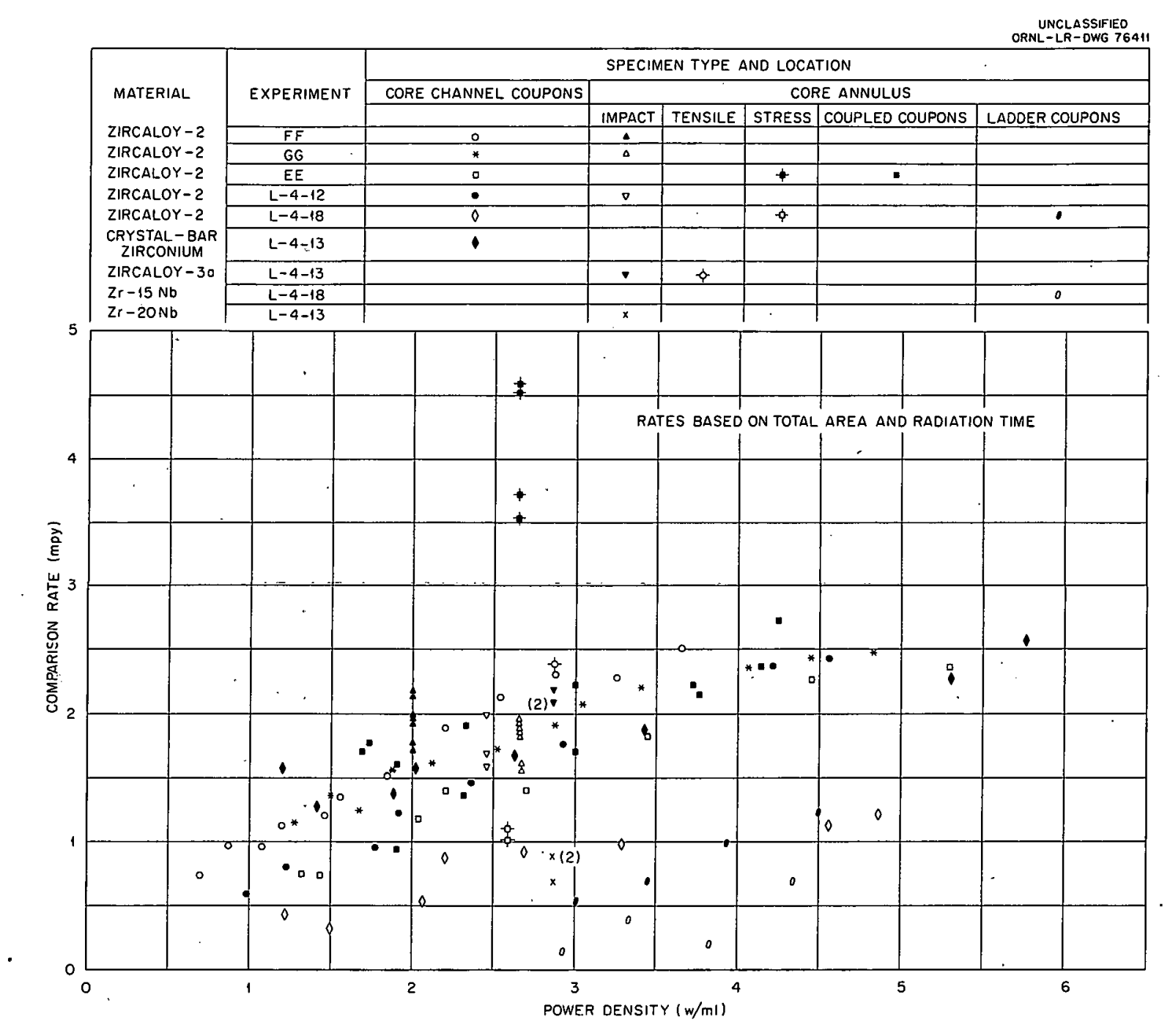

Fig. 75. Crystal-Bar Zirconium and Zirconium-Alloy Corrosion Data.

\subsubsection{Charged Solutions - Nonradioactive Samples}

These solutions were regularly analyzed for $\mathrm{U}, \mathrm{Cu}, \mathrm{SO}_{4}, \mathrm{Ni}$, and $\mathrm{pH}$. In two experiments, free-acid' analyses were also made. Considerations of the cation-anion balances and the $\mathrm{pH}$ results for loops $\mathrm{DD}$ through L-4-12 show some inconsistencies which, in general, can be explained either by an error of -0.05 in the $\mathrm{pH}$ measurements or by errors in the ion analyses, with the maximum error for any one analysis as follows: uranium, $-2.5 \%$; sulfate, $+2.5 \%$; or copper, $-20 \%$. In experiment $F F$, the discrepancies were greater, and the errors in the ion analyses or $\mathrm{pH}$ required to explain the results were about three points greater than those mentioned above. In experiments L-4-13 and L-4-18, the cation-anion balances and the 


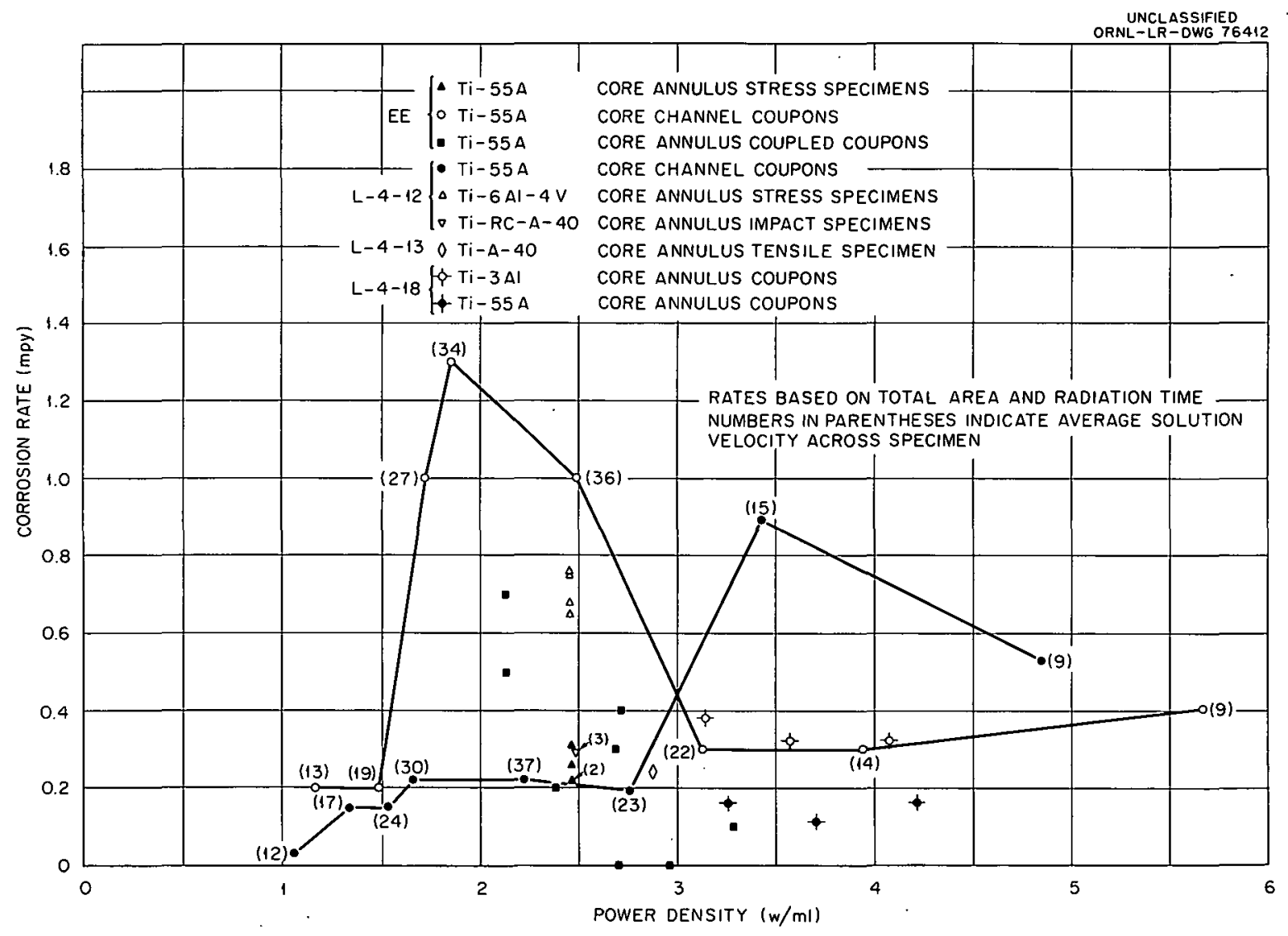

Fig. 76. Titanium Corrosion Data.

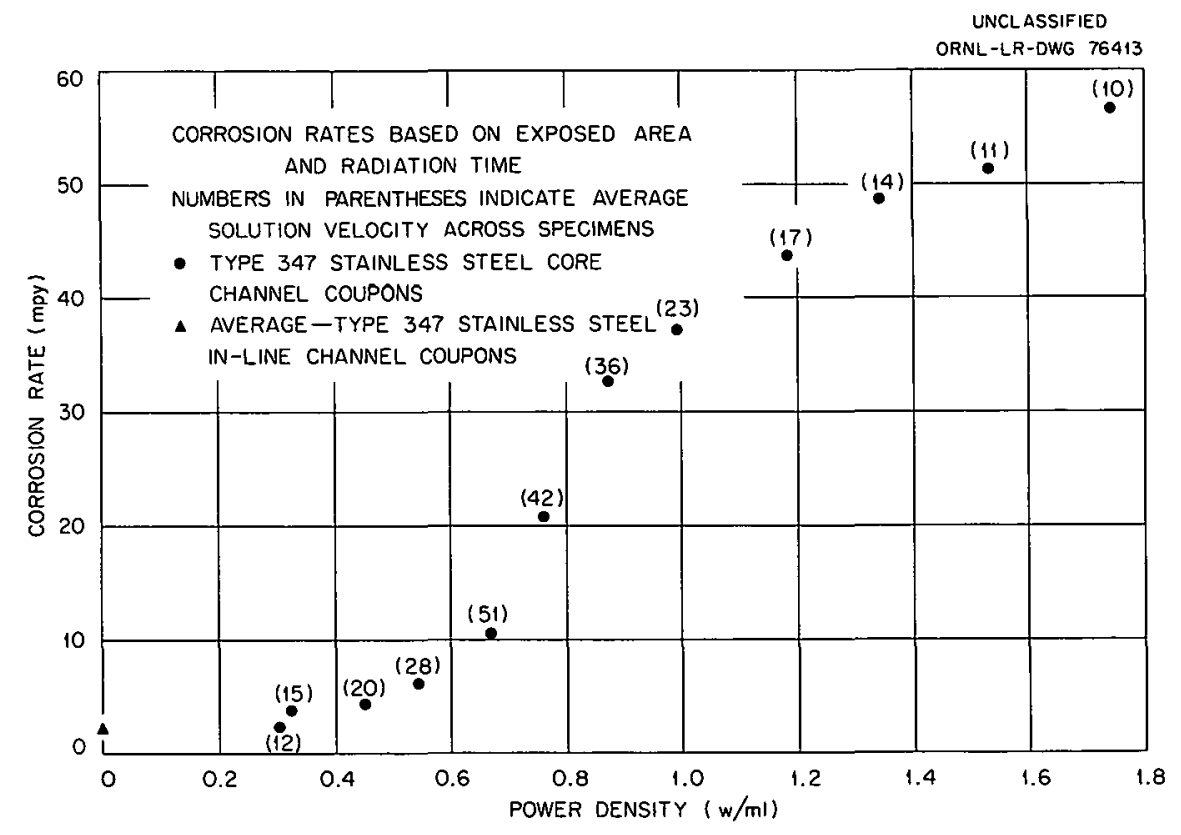

Fig. 77. Stainless Steel Corrosion Data, Loop DD. 
UNCLASSIFIED

ORNL-LR-OWG 76414

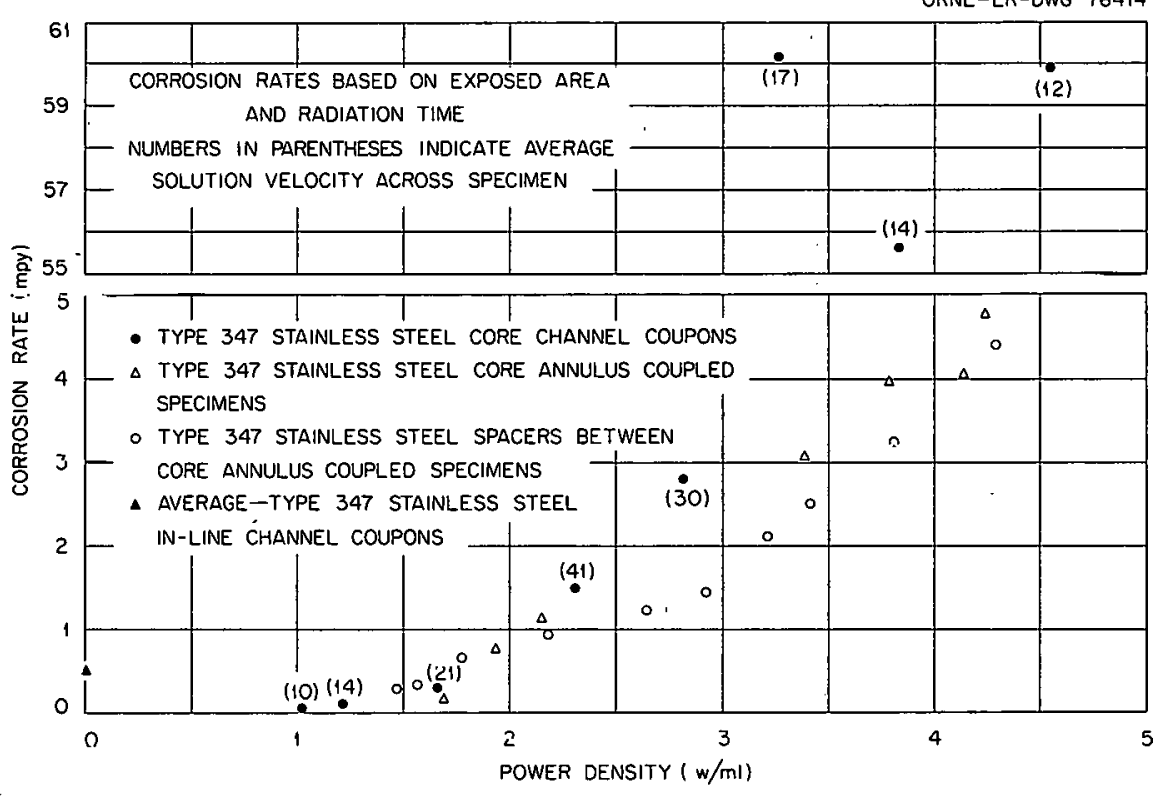

Fig. 78. Stainless Steel Corrosion Data, Loop EE.

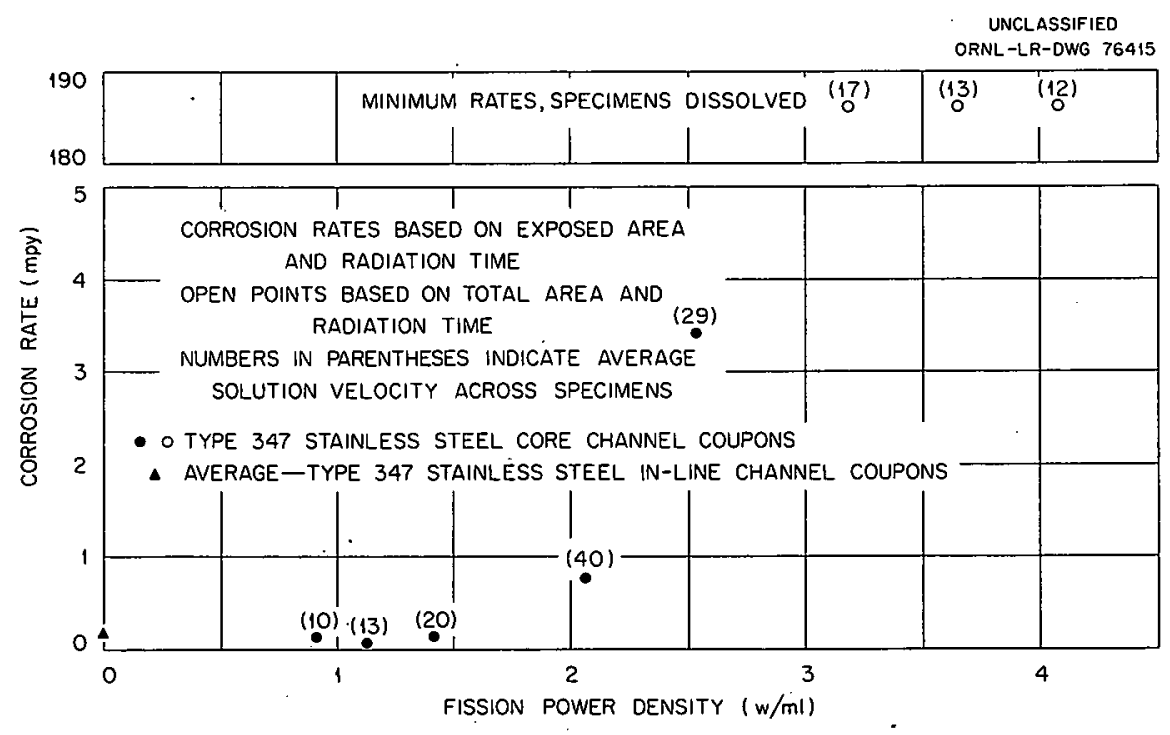

Fig. 79. Stainless Steel Corrosion Data, Loop L-4-12. 


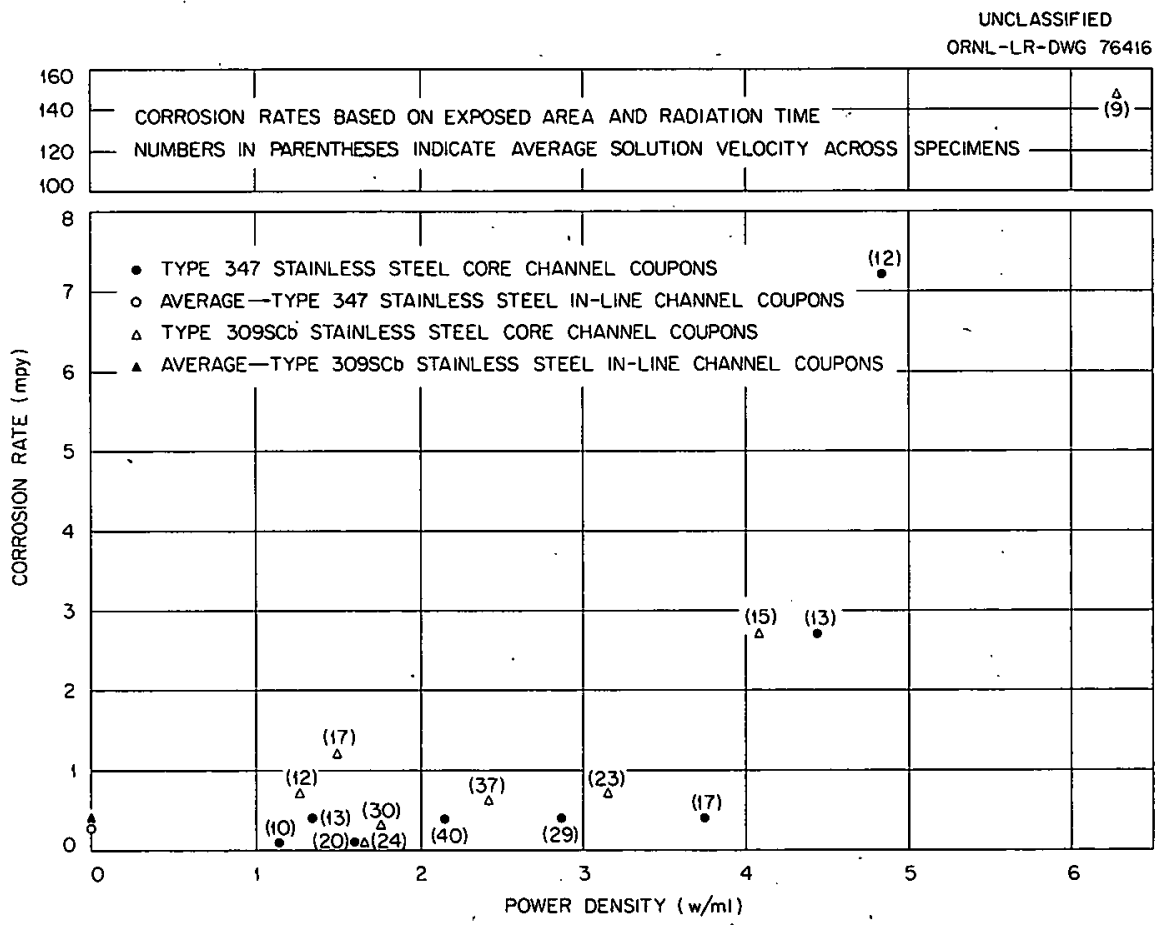

Fig. 80. Stainless Steel Corrosion Data, Loop L-4-13.

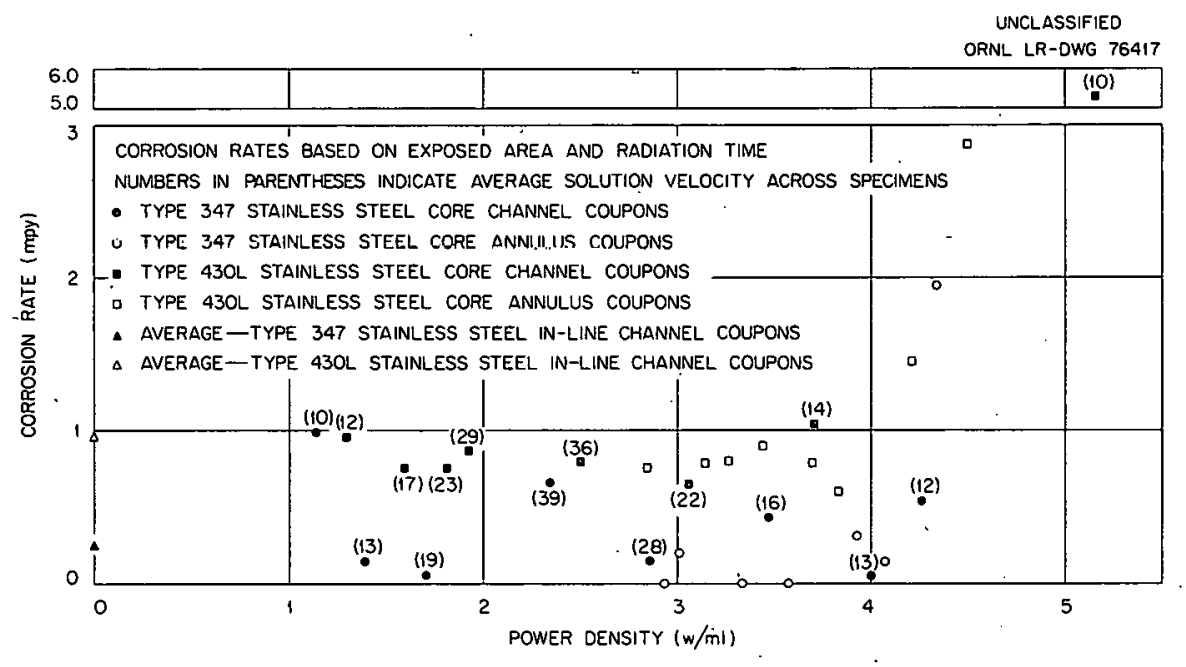

Fig. 81 . Stainless Steel Corrosion Data, Loop L-4-18. 
free-acid analyses are in near agreement. The relationship between free-acid and glass-electrode $\mathrm{pH}$ readings on these $\mathrm{D}_{2} \mathrm{O}$ solutions was not established independently, and the $\mathrm{pH}$ readings were not employed in evaluating the results.

Considering that highly developed, accurate methods for uranium analyses and for $\mathrm{pH}$ measurements were available from the start of these experiments and that very large errors in the copper analyses are required to explain the discrepancies, it is believed that errors in sulfate analyses were largely responsible for the observed discrepancies.

\subsubsection{Uranium, Copper, and Sulfate in Loop Solutions During Irradiations}

Experiments Employing $\mathrm{Li}_{2} \mathrm{SO}_{4}$ Tracer to Establish Sample Dilutions - Loops GG, EE, L-4-12, L-4-13. and $L$-4-18. - From reference to the plots of the analytical data for these experiments (Figs. 9, 11-14), it can be seen that appreciable scatter occurred both in the analytical values reported for the sample's and in those values obtained by correcting reported values by the lithium dilution factors. In general, however, the corrected values fall nearest the calculated values, that is, to the values calculated from inventory balance, assuming no loss of solutes from solution. Within the scatter of the data, the re are no apparent trends to lower or higher concentrations for uranium, copper, or sulfate during in-pile exposure of these experiments, and consideration of these analytical data in terms of the average values appears valid.

In Table 43, average values are set forth for (1) analytical values for uranium, sulfate, and copper corrected for dilution, using the lithium dilution factor in one case and the uranium dilution factor in another case, and (2) calculated values for the same species. The uranium dilution factor was taken as the ratio of the calculated to reported uranium. Considering first those values corrected by the lithium dilution factor, the corrected uranium values are near the calculated but are slightly higher in each case (from $0.5 \%$ for $\mathrm{L}-4-12$ to $6.2 \%$ for L-4-18). The corrected values in most cases are also higher than the calculated, while the corrected copper values are lower in most cases. The sulfate values calculated with the uranium dilution factor fall within $2 \%$ of the calculated values for L-4-12, L-4-13, and L-4-18. The sulfate value for GG is about $5 \%$ greater than the calculated value, while the corrected value for $E E$ is about $4 \%$ below the calculated. The corrected copper values fall below the calculated by amounts varying from 1 to $11 \%$.

A further evaluation of the data for the major consituents, uranium and sulfate, can be made from comparisons between free-acid values for solution samples from (1) cation-anion balance, (2) inventory balance, assuming that acid was consumed only in the dissolution of nickel and manganese in the amounts found in the samples, and (3) $\mathrm{pH}$ measurements. The acid values determined from cation-anion balance are generally greater than those estimated by the other methods, as illustrated in Fig. 82 for those samples from experiment $\mathrm{GG}$ for which $\mathrm{Li}_{2} \mathrm{SO}_{4}$ tracer was employed. For these samples the acid values from cation-anion balance were consistently greater than those estimated by the other methods, and the average amount of the difference was $0.035 \mathrm{~m}$. These discrepancies cannot readily be explained by assuming that the corrected uranium values were lower than the true values, since the corrected values were near or above the calculated ones in all cases. Also, they are not readily explained by the assumption of errors 
Table 43. Average of Values for Concentrations of Uranium, Sulfate, and Copper in the Experiments

\begin{tabular}{|c|c|c|c|c|c|c|c|c|}
\hline \multirow{3}{*}{ Experiments } & \multicolumn{8}{|c|}{ Average of Values $(\mathrm{mg} / \mathrm{ml})$} \\
\hline & \multicolumn{2}{|c|}{ Uranium } & \multicolumn{3}{|c|}{ Sulfate } & \multicolumn{3}{|c|}{ Copper } \\
\hline & $\begin{array}{l}\text { Corrected }^{a} \\
\left(\mathrm{Li}_{2} \mathrm{SO}_{4}\right)\end{array}$ & Calculated $^{b}$ & $\begin{array}{l}\text { Corrected }^{a} \\
\left(\mathrm{Li}_{2} \mathrm{SO}_{4}\right)\end{array}$ & $\begin{array}{c}\text { Corrected }^{c} \\
\text { (U) }\end{array}$ & Calculated $^{b}$ & $\begin{array}{l}\text { Corrected }^{a} \\
\left(\mathrm{Li}_{2} \mathrm{SO}_{4}\right)\end{array}$ & $\begin{array}{c}\text { Corrected } \\
\text { (U) }\end{array}$ & Calculated ${ }^{t}$ \\
\hline \multicolumn{9}{|l|}{ With $\mathrm{Li}_{2} \mathrm{SO}_{4}$ tracer } \\
\hline GG & 40.0 & 39.5 & 25.8 & 24.9 & 23.4 & 1.68 & 1.66 & 1.73 \\
\hline EE & 39.5 & 38.4 & 20.3 & 20.3 & 21.2 & 1.72 & 1.67 & 1.76 \\
\hline L-4-12 ( 1 st solution) & 40.0 & 39.8 & 25.2 & 25.1 & 24.5 & 2.00 & 1.99 & 2.01 \\
\hline$L-4-13$ & 42.5 & 41.0 & 23.1 & 22.5 & 22.2 & 1.98 & 1.93 & 2.14 \\
\hline$L-4-18$ & 42.3 & 39.8 & 27.1 & 25.4 & 24.9 & 4.37 & 4.11 & 4.35 \\
\hline \multicolumn{9}{|l|}{ Without $\mathrm{Li}_{2} \mathrm{SO}_{4}$ tracer } \\
\hline DD & & 35.0 & & 19.7 & 18.1 & & 1.71 & 1.71 \\
\hline FF & & 39.3 & & 25.8 & 24.8 & & 1.97 & 1.76 \\
\hline GG & & 39.8 & & 25.0 & 23.4 & & 1.85 & 1.75 \\
\hline
\end{tabular}

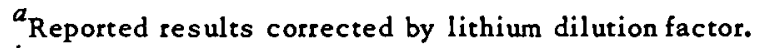

${ }^{b}$ Obtained from inventory balance of charged and removed solutions.

$c_{\text {Reported results corrected by uranium dilution factor. }}$ 


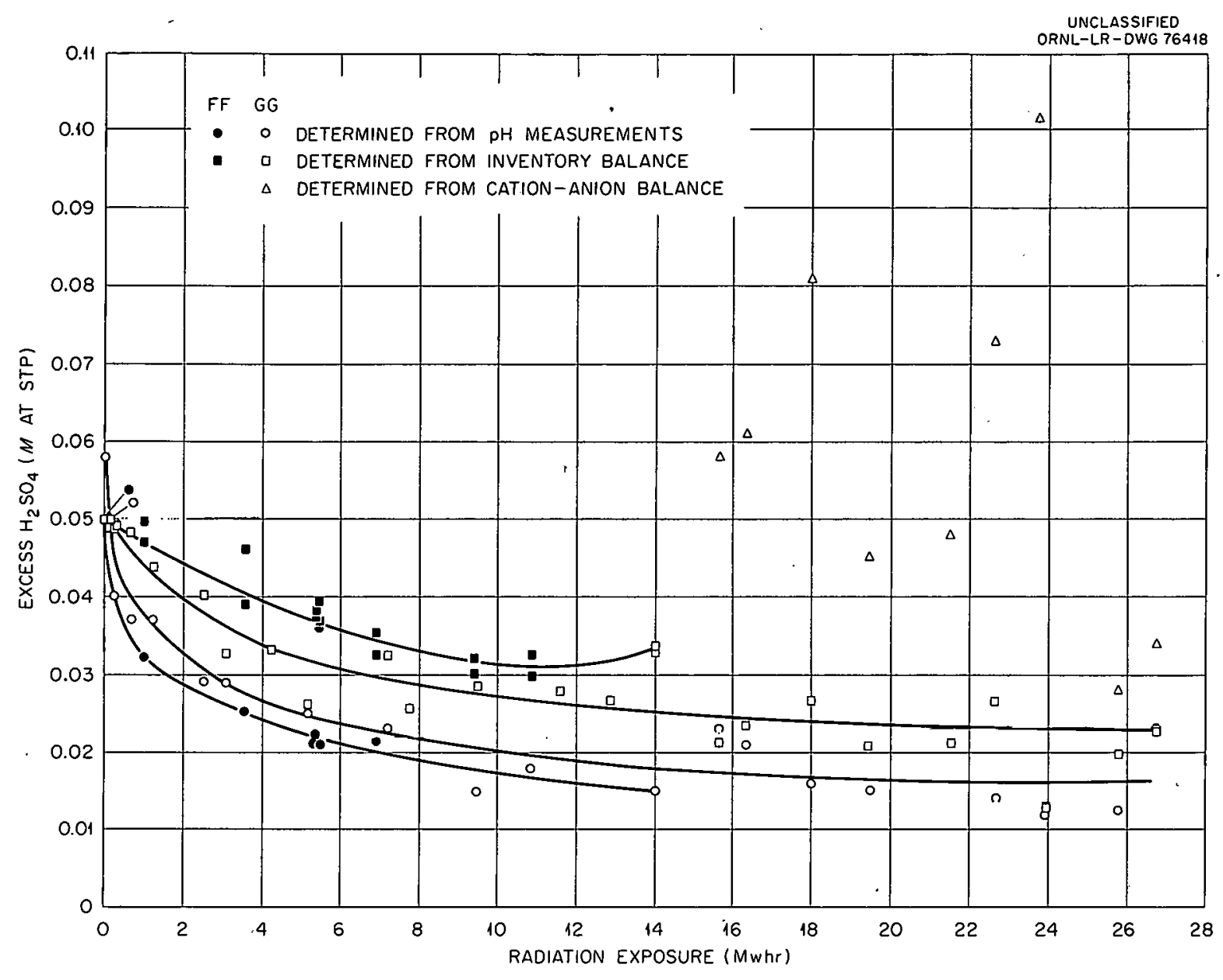

Fig. 82. Excess $\mathrm{H}_{2} \mathrm{SO}_{4}$ Concentration in Loops FF and GG.

in the analytical results for other cations such as nickel, since such errors would have to amount to factors of 2 or more in most cases. The discrepancies can be explained by assuming that the reported and corrected values for sulfate were generally in error on the high side, and this is believed to be the correct explanation.

On the basis of such considerations, the interpretations of the analytical results believed to be most reasonable and likely are the following:

1. On the average, there was no significant loss of uranium or sulfate from any of the solutions under consideration.

2. The average value for the dilution factor deduced from lithium was somewhat high in most experiments (in the range 0 to $5 \%$ for experiments $L-4-12$ and $L-4-18$ respectively).

3. Significant amounts of copper were lost from most of the solutions. The percentage losses ranged from $1 \%$ in $\mathrm{L}-4-12$ to $11 \%$ in $\mathrm{L} \cdot 4-13$. 
Experiments Which Did Not Employ $\mathrm{Li}_{2} \mathrm{SO}_{4}$ Tracer - DD, FF, and GG. - Since it is considered likely that no uranium was lost from experiments employing $\mathrm{Li}_{2} \mathrm{SO}_{4}$ tracer, it is also likely that no uranium was lost from those other experiments which employed comparable solutions but no tracer. The averages of reported analytical values for sulfate and copper, corrected for dilution by using the uranium factors, are listed in Table 43. These sulfate results are comparable to those for the previously mentioned experiments. However, no loss of copper was indicated for these experiments.

\subsubsection{Free Acid in Solutions During Irradiation}

The free-acid values considered most reliable are those determined from direct analytical measurements, where such measurements were made, or from $\mathrm{pH}$ readings in other experiments. The results of free-acid measurements and estimates have been illustrated previously (Fig. 82).

The data in Fig. 83 show that the free acid in some of the experiments decreased rapidly following the initiation of irradiation and then tended to level off. In other experiments for which the initial excess acid concentrations were lower, the initial decrease was less marked. In some experiments no decreases occurred, but instead the acidities increased slightly. The se changes in acid concentration and the difference between the several experiments are qualitatively explained by several factors: (1) much of the decrease in acidity resulted from stainless steel corrosion and the concomitant neutralization of acid by

the dissolution of nickel and manganese, (2) the rate of corrosion of steel under irradiation was dependent upon the excess acid concentration, increasing with increasing acidity, and (3) acid was added to the loops with makeup solutions during irradiation, and in cases where the corrosion rates were low, the additions counter-balanced or outweighed the loss resulting from corrosion. The effect of acid on steel corrosion will be discussed in detail in later paragraphs.

In general, the acidity values determined from inventory balance, considering acid addition and withdrawals and neutralization of acid by nickel and manganese in solution, and from $\mathrm{pH}$ measurements were in rather poor agreement, as illustrated in Figs. 82 and 84 for the data from FF, GG, and L-4-12. The sources of the discrepancies between the values determined by the different methods are unknown. Sources which are considered possible include (1) errors in nickel and manganese analyses, (2) loss of acid by sorption on corrosion product oxides, and (3) loss of nickel by sorption as nickel sulfate, as mentioned in the following section. Some uncertainty exists also in the acid values from $\mathrm{pH}$ measurements, but $\mathrm{pH}$ measurements comprise direct determinations of acidities which are considered more reliable than those determined from inventory balance.

\subsubsection{Nickel in Irradiated Solutions}

The analytical data for nickel in solution can be used to calculate the total amount of steel oxidized at a given time if it is assumed that no selective oxidation of any steel component occurred and that all oxidized nickel was in solution. The steel corrosion calculated in this way was shown graphically and compared with the oxygen consumption data in Figs. 15-21. However, the oxygen data shown there were 


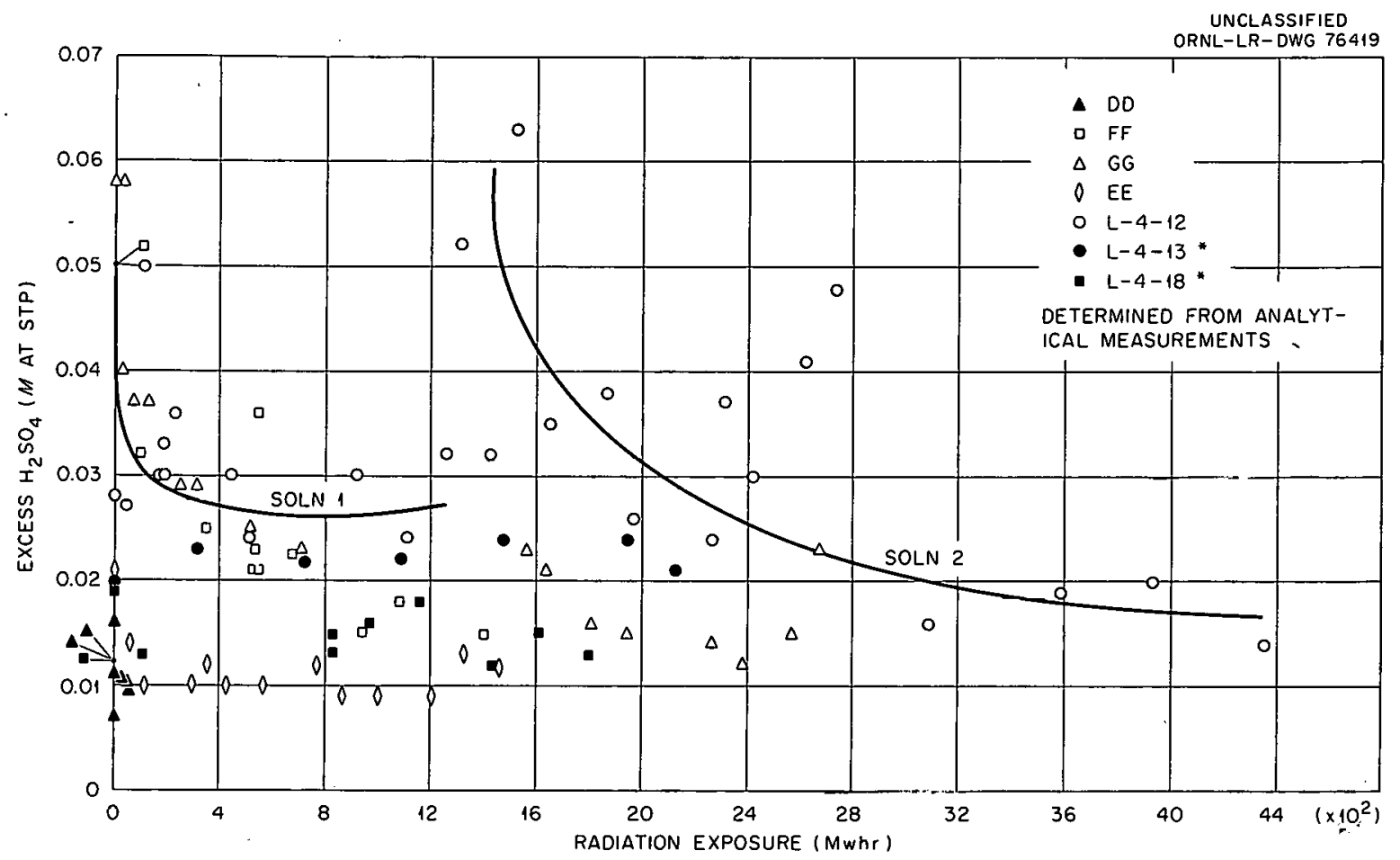

Fig. 83. Excess $\mathrm{H}_{2} \mathrm{SO}_{4}$ Concentration in Several Loop Experiments Determined from pH or Analytical Measurements.

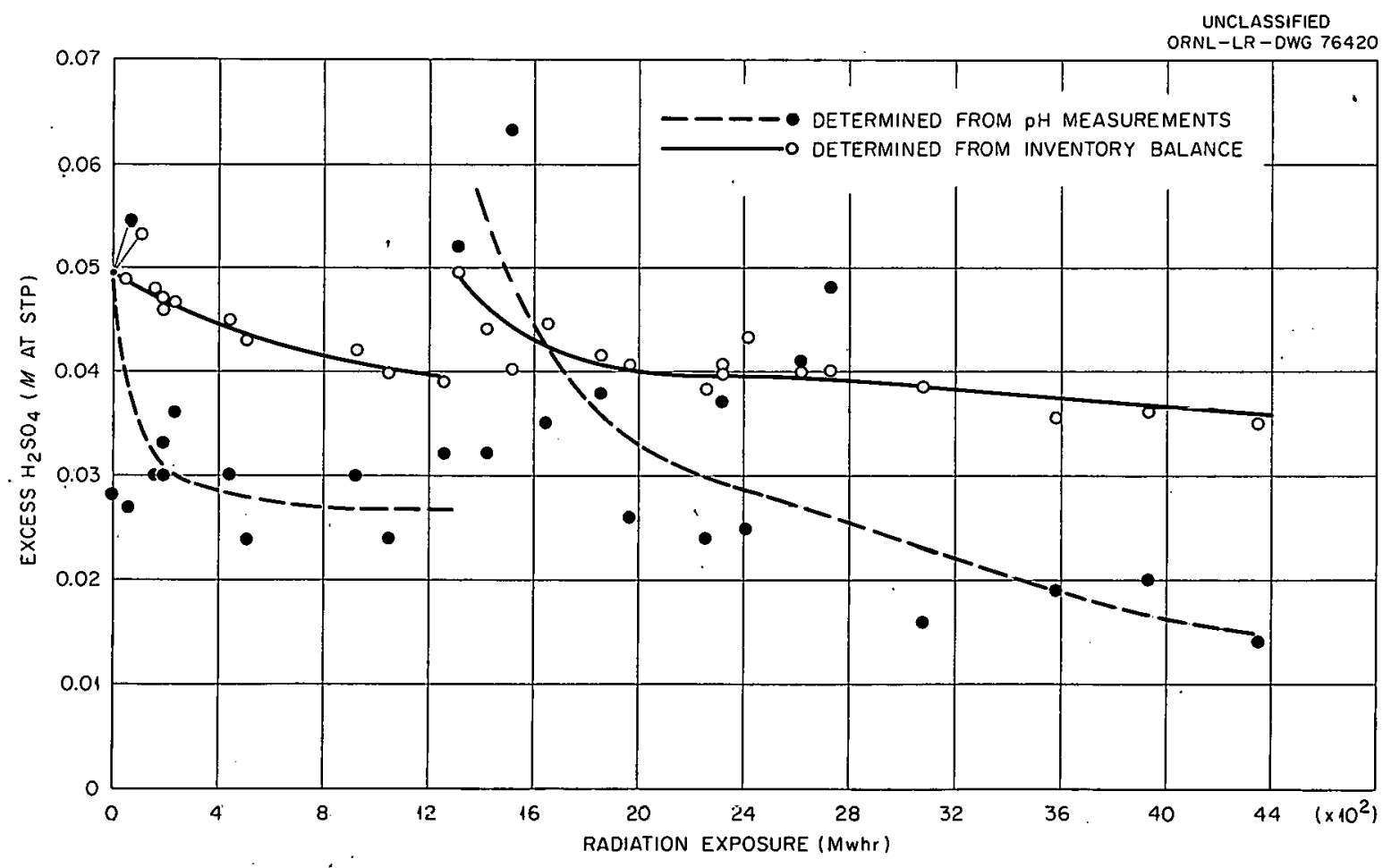

Fig. 84. Excess $\mathrm{H}_{2} \mathrm{SO}_{4}$ Concentration in Loop L-4-12. 
uncorrected for consumption by zirconium and titanium alloys. The best values for total oxygen consumption by steel determined from oxy gen and nickel data are compared in Table 44. The nickel values were determined from those shown in Figs. 15-21. The oxygen values, corrected for con sumption by zirconium and titanium alloys, were taken from the plots shown in Fig. 30. The time selected for comparison was near the end of the in-pile exposure in each case.

Table 44. Comparison of Total Amounts of Steel Corrosion Determined from Oxygen Uptake and Dissolved Nickel Data

\begin{tabular}{|c|c|c|c|c|}
\hline \multirow[b]{2}{*}{ Experiment } & \multirow[b]{2}{*}{$\begin{array}{l}\text { Time } \\
\text { (Mwhr) }\end{array}$} & \multicolumn{2}{|c|}{ Calculated Oxygen Consumption by Steel } & \multirow{2}{*}{$\begin{array}{l}\text { Ratio of Consumption } \\
\text { from Oxygen Data to } \\
\text { That from Nickel Data }\end{array}$} \\
\hline & & $\begin{array}{l}\text { Oxygen Consumption } \\
\text { Data }{ }^{a} \\
\text { (cc at STP) }\end{array}$ & $\begin{array}{l}\text { Nickel Data } \\
\text { (cc at STP) }\end{array}$ & \\
\hline $\mathrm{DD}$ & 840 & 1730 & 1200 & 1.44 \\
\hline $\mathrm{FF}$ & 1400 & 4760 & 2440 & 1.95 \\
\hline GG & 2550 & 4470 & 3760 & 1.18 \\
\hline $\mathrm{EE}$ & 1460 & 2100 & 1750 & 1.20 \\
\hline$L-4-13$ & 2300 & 3220 & 1760 & 1.83 \\
\hline$L-4-18$ & 1920 & 760 & 510 & 1.49 \\
\hline
\end{tabular}

\footnotetext{
${ }^{a}$ From graphs shown in Fig. 30.

${ }^{b}$ Calculated from data in Tables 6-12, assuming (1) no selective oxidation of any steel component, (2) all oxidized nickel in solution, and (3) that the type 347 steel contained $12.5 \%$ nickel.
}

As listed in the final column of Table 44, the total steel corrosion indicated by the oxygen was appreciably greater than that indicated by nickel - nearly a factor of 2 in one case, and an average difference of a factor of 1.5 for the six experiments. The se results indicate (1) that the nickel analyses were in error or (2) that part of the nickel formed in corrosion either did not dissolve or, if dissolved, left solution by sorption or precipitation. The latter indication is supported by the significant amounts of nickcl found in the heavy scales in the in-line positions. (Scale from the inaline Zircaloy-2 holder in experiment GG contained $2 \%$ nickel by weight. Bulk scale from experiment $L-4-18$ contained 2 to $7 \%$ nickel.) It is also supported by results obtained in subsequent experiments at higher temperatures which have shown appreciable amounts of nickel in the heavy scales. ${ }^{34,35}$ In one of the high-temperature experiments, the total amount of nickel found in scales and solution indicated that nickel was selectively oxidized from the type 347 stainless steel. 35

${ }^{34}$ G. H. Jenks and J. E. Baker, HRP Radiation Corrosion Studies: In-Pile Loops L-2-15 and L-4-16, ORNL-3099 (in preparation).

${ }^{35}$ G. H. Jenks and J. E. Baker, HRP Radiation Corrosion Studies: In-Pile Loop L-2-17, ORNL-2974 (in prepara- 
As shown in Fig. 16, the amounts of manganese in solution were sometimes in rough agreement with those estimated from the nickel data, assuming (1) about $1 \%$ manganese in the type 347 steel, (2) no selective oxidation of any of the steel constituents, and (3) complete solubility of the nickel and manganese. Usually, however, the amounts of manganese found in solution were much less than the proportionate amount estimated from the nickel in solution (Figs. 19 and 20). This shows that the oxidized manganese was usually not completely dissolved or, if dissolved, was deposited and retained on loop surfaces.

It may be pointed out here that a possible explanation for the observed discrepancies between freeacid concentrations calculated from $\mathrm{pH}$ and from inventory balance, assuming acid neutralization by nickel and manganese in solution (Figs. 82 and 84), is that nickel was sorbed from solution as nickel sulfate, so that the amounts of acid neutralized were greater than those calculated from the amounts of nickel in solution.

\subsubsection{Other Constituents of Loop Solutions}

Zirconium in amounts ranging up to $50 \mathrm{ppm}$ and more (greater than $100 \mathrm{ppm}$.in some cases) was found in all solutions during in-pile operations. These findings indicate an appreciable solubility for this material or its compounds. (It is considered possible that the material in solution was in a colloidal form.) The appreciable solubility is consistent with the findings made in subsequent loop experiments ${ }^{34}$ that most of the zirconium oxide formed in loop cores.is transported to and deposited on surfaces nutside the high-flux regions of the core.

Significant amounts of chromium were found in many of the loop samples (usually less than $100 \mathrm{ppm}$ ). The valence state for this chromium is unknown. Considerations by Banter et al. ${ }^{36}$ of the possible oxidizing effects of radicals produced during irradiation and of the reducing environment provided by hydrogen and copper in solution suggest that both valence states may be present during irradiation.

Iron was also found in most of the loop samples, again at concentrations usually less than $100 \mathrm{ppm}$. The identity of the soluble species is unknown.

Cobalt was sought in several of the early experiments which employed stellite pump-journals in order to follow the corrosion of the stellite. The cobalt found in solution was small in all cases and was less than $25 \mathrm{pPm}$ in experiments $\mathrm{FF}$ and $\mathrm{EE}$. In the first experiment DD, the cobalt reached a concentration of about $160 \mathrm{ppm}$.

Chlorine was detected at a concentration level of a few parts per million in most of the experiments. It is believed that these low concentrations had negligible effects on the steel corrosion. No stress cracking has been observed in any sut-of-pile tests with solutions containing $<5$ ppm of chloride inn. ${ }^{37}$

${ }^{36} \mathrm{~J}$. C. Banter, J. E. Baker, and R. J. Davis, Analysis of the Status of Chromium in Solution Under In-Pile Conditions, ORNL CF-58-7-63 (July 1958).

${ }^{37}$ E. G. Bohlmann, "Integrity of Metals in Homogeneous Reactor Media," p 283 in Fluid Fuel Reactors (ed. by J. A. Lane et al.), Pt. 1, Addison-Wesley, Reading, Mass., 1958. 


\subsection{Corrosion of Type 347 Stainless Steel During In-Pile Exposure}

\subsubsection{General}

The principal material of construction in these loops was type 347 stainless steel. The overall corrosion of this material was followed by oxygen consumption and nickel accumulation mea surements. Corrosion in specific locations was followed in some of the loops through corrosion specimens. Metallographic and visual examinations were made of loop components and of specimens when available.

Steel specimens exposed in the loop cores showed increases in corrosive attack over that expected out-of-radiation, as illustrated in Figs. 77-81. As shown, the average rates of corrosion increased with power density in adjacent solution, but below certain power densities the average rate was not noticeably different from that occurring on in-line specimens. The corrosion occurring on in-line and low-power-density specimens was not significantly different from that expected during out-of-pile exposures (weight losses of $1 \mathrm{mg} / \mathrm{cm}^{2}$ or less on pretreated specimens ${ }^{38}$ ). The se specimen results thus indicate that the effects of in-pile exposure on steel corrosion were confined to the core.

The results of metallographic and visual examinations of specimens and components also indicated that, for surfaces located outside the core and at low-power densities with in the core, the corrosion was not signficantly different from that expected out-of-pile, with the possible exception of the deep corrosion pit which formed at the site of the pinhole weld in loop FF (see Sec 4.6.2).

A like indication was given also by the oxygen consumption results for the titanium-core experiment, L-4-12, in comparison with those of other steel-core experiments which employed solutions of about the same composition. As shown in Fig. 19, the rate of oxygen consumption on steel in L-4-12 at the initiation of irradiation with the first solution charge did not differ significantly from that prevailing prior to irradiation. With the second solution charge, the maximum at the initiation of irradiation was $4.6 \mathrm{cc} / 3$ Mwhr or less. In comparison, the initial consumption rates in experiments GG and FF were about 25 and $16 \mathrm{cc} / 3 \mathrm{Mwhr}$ respectively. The lower initial rates in L-4-12 can be explained by assuming that the major effects of irradiation on steel corrosion occurred only on surfaces exposed to fissioning solution in the core, and that the rate of oxygen consumption by steel in experiment L-4-12 was much lower than those in experiments GG or FF because of the lower area of steel in the core of L-4-12 $\left(37 \mathrm{~cm}^{2}\right.$ vs $445 \mathrm{~cm}^{2}$ in GG or FF).

Based on the above observations it has been conclucied that the irradiation effect on steel corrosion was confined to the surfaces within the core.

The power-density value at which the radiation effects became noticeable varied from $0.3 \mathrm{w} / \mathrm{ml}$ in DD to $3.8 \mathrm{w} / \mathrm{ml}$ in $\mathrm{L}-4-13$ for the $250^{\circ} \mathrm{C}$ experiments. In the $235^{\circ} \mathrm{C}$ experiment, $\mathrm{L}-4-18$, the value was 4.2 $\mathrm{w} / \mathrm{ml}$. The corrosion of those core specimens of type 347 stainless steel which were most severely attacked appeared to proceed through formation of pits, about $1 \mathrm{mil}$ in depth, which then spread laterally to result in a fairly uniform attack of a surface. It should be noted that although the core specimen results are presented in terms of average rate values, the actual rates probably changed considerably during

\footnotetext{
${ }^{38} \mathrm{~J}$. C. Griess and R. E. Wacker, HRP Quart. Progr. Repi. Jan. 31, 1954, ORNL-1678, PP 60-63.
} 
the course of an experiment as indicated by the changes in rate of oxygen consumption (at the extremes, a factor of about 40 from the maximum to minimum in experiment GG, and a factor of 2 in experiment EE, Figs. 16 and 18).

There was no effect of stress on core and in-line steel corrosion in the one experiment, EE, in which this factor was investigated. Also there was no effect of galvanic coupling with other materials tested in the same experiment. In general, the amount of scale removed from core specimens by defilming was small and much less than that from in-line specimens. This indicates that much of the steel corrosion product oxides found in the core were transferred to and deposited on in-line surfaces. Zirconium-alloy corrosion products behave similarly. ${ }^{34}$

Type 309SCb stainless steel specimens tested in one experiment, L-4-13, exhibited about the same general relationship between power density and rate as type 347 stainless steel, but the type 309 rates at a given power density were somewhat greater than those for type 347. A similar difference between the radiation effect on the two steels has been observed in subsequent loop experiments at higher temperatures. ${ }^{34}$

Type 430L stainless steel specimens in experiment $L-4-18$ were affected by exposure to fissioning solution to about the same extent as type 347 steel. It may be noted, however, that in a subsequent experiment at $300^{\circ} \mathrm{C}$ (ref 31) type 430 steel performed better than type 347.

\subsubsection{Effects of Solution Velocity on Core Specimen Corrosion}

Most of the core specimens of stainless steel were mounted in the main core channel holders, where they were exposed to solution velocities ranging from about $10 \mathrm{fps}$ for the forward and rear specimens to about $40 \mathrm{fps}$ for the central specimens. For experiment DD the shape of the rate-power-density curve (Fig. 77) suggests an effect of solution velocity on the corrosion. An analyses of these data by the Mathematics Division produced the following relationship between these variables;

$$
\log \text { penetration }(100 \times \text { mils })=0.791-0.21 V+0.603 P-0.0885 P^{2}+0.0237 P V,
$$

where $P=$ power density $(\mathrm{w} / \mathrm{ml}), V=$ solution velocity (fps). This analysis indicates that the net effect of increasing velocity with in the range 10 to $40 \mathrm{fps}$ was to reduce the power-density effect on corrosion. The channel data from the other experiments have not been analyzed in a similar fashion. However, in another $250^{\circ} \mathrm{C}$ experiment reported elsewhere, ${ }^{39}$ there was an obvious adverse effect of high solution velocities on the corrosion of the $\mathrm{CC}$ specimens. In experiment $\mathrm{EE}$, specimens exposed in the low-velocity $(\sim 1 \mathrm{fps})$ annulus regions exhibited penetrations which were lower than those for the channel specimens, but in L-4-18 the annulus rates were about the same or only a little less than those in the channel.

In summary, some of the data obtained in these and subsequent experiments ${ }^{35}$ indicate an adverse effect of increasing solution velocity on steel corrosion under exposure to fissioning uranyl sulfate solutions, while others indicate beneficial effects. It may be speculated that either effect may occur, depending upon the experimental conditions. A beneficial effect might be expected to occur by the mechanism

\footnotetext{
1956).

${ }^{39}$ J. E. Baker and G. H. Jenks, HRP Radiation Corrosion Studies: In-Pile Loop L-4-8, ORNL-2042 (Aug. 8 ,
} 
prevailing in Zircaloy-2 corrosion in which the amounts of uranium sorbed near a surface and, thus, the effective power density at the surface decreased with increasing solution velocity. An adverse effect of velocity occurs out-of-radiation on unpretreated specimens, and a similar effect may occur in-pile after the protective film has been damaged during irradiation. The experimental conditions under which one or the other effects predominates are unknown.

\subsubsection{Comparison Between Total Amounts of Steel Corrosion Determined from Oxygen Consumption and from Nickel Accumulation}

A comparison between the amounts of steel corrosion determined by the two methods was presented in Table 44 and discussed in Sec 5.1.4. The oxy gen data indicate the greater amount of steel corrosion and are considered the most accurate measure of the total steel corrosion.

\subsubsection{Correlations Between Solution Composition and Rate of Oxygen Consumption by Steel}

As shown in Figs. 15-21, the rates of oxygen consumption by steel during irradiation varied from one experiment to another. Also, the rate in a given experiment changed to generally lower values as the exposure progressed. Variations in the total consumption of oxygen by steel also occurred. As shown in Fig. 30, plots of total consumption vs exposure time exhibited a characteristic pattern (except L-4-12) in which the rate of consumption remained essentially constant for a long period following the initiation of irradiation and then changed to a second, lower rate which, in general, prevailed for the remainder of the exposure. However, the initial rates as well as the total consumption prior to the break were different for the different experiments.

A cursory examination of the conditions and results for the $250^{\circ} \mathrm{C}$ experiments reported here, together with those for the previously reported experiment $L-4-11,40$ shows that the differences in steel corrosion were related to differences in the concentrations of excess acid and, probably, nickel in the test solutions. For example, total oxygen consumption prior to the break (Fig. 30) was greater for experiments GG and FF, which were charged with solution containing about $0.05 \mathrm{~m}$ excess acid, than for the experiments employing initial acidities of 0.015 to $0.02 m$ (DD, EE, L-4-13). Also, in experiment L-4-11, for which the initial solution contained about $0.01 \mathrm{~m} \mathrm{NiSO}_{4}$ but was otherwise comparable to that employed with GG and FF, the total consumption prior to the break was less than in either FF or GG. The initial rates under irradiation were also greatest for those solutions with the highest acidities.

The results of efforts to obtain quantitative correlations between steel corrosion rates and solution compositions are shown in Figs. 85 and 86 and in Table 45. In Fig. 85, values for the rate of oxygen consumption per unit area of exposed steel surface in the core and per unit fission power in the core during irradiation at $3 \mathrm{Mw}$ LITR power are plotted vs excess $\mathrm{H}_{2} \mathrm{SO}_{4}$ concentration for all the present $250^{\circ} \mathrm{C}$ experiments which employed steel cores except DD and for the previously reported experiment L-4-11. In Fig. 1958).

40 J. R. Mctherter and J. E. Baker, HRP Radiation Corrosion Studies: In-Pile Loop L-4-11, ORNL-2152 (June 11, 


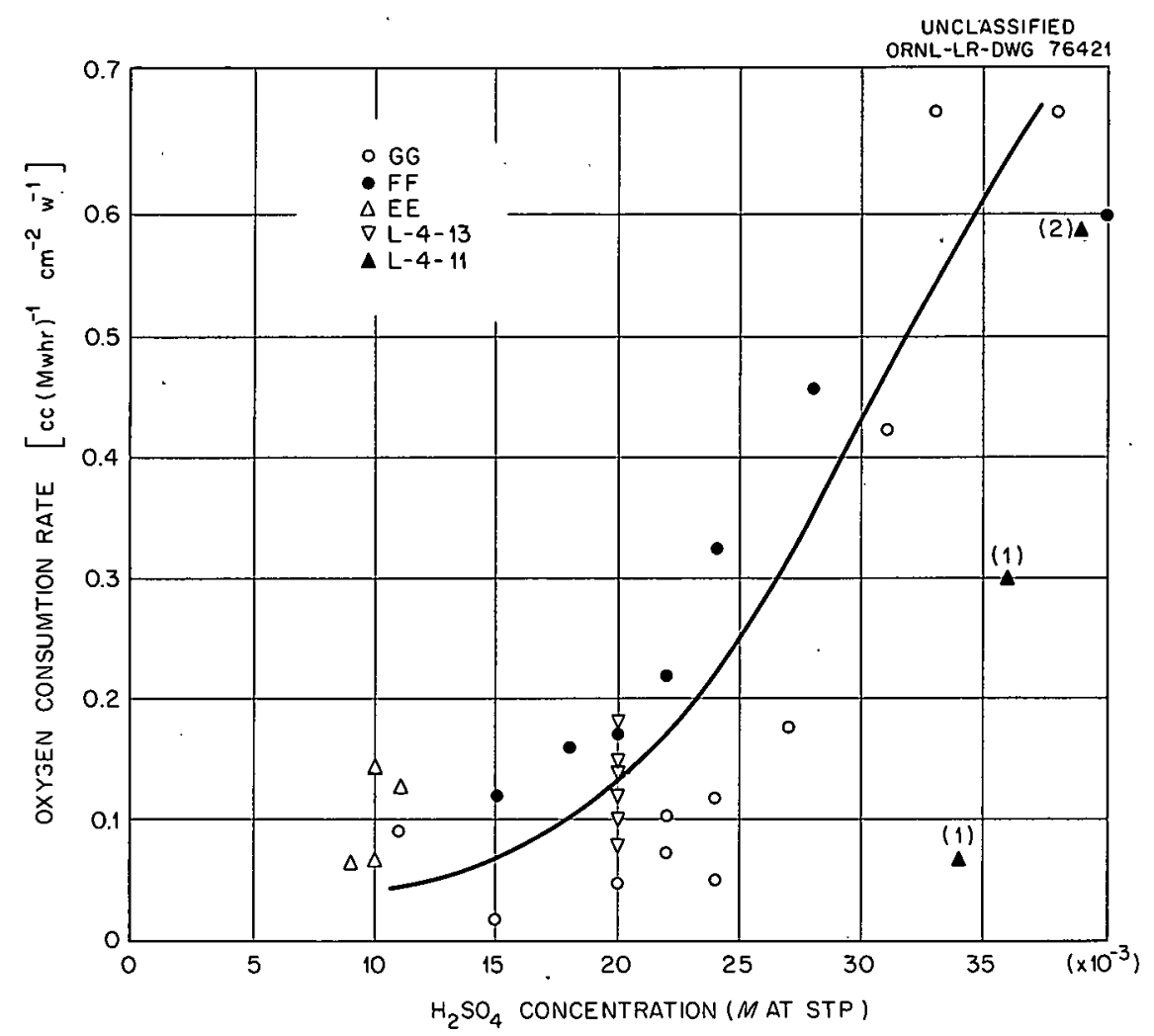

Fig. 85. Rate of $\mathrm{O}_{2}$ Cansumption per Unit Area of Exposed Steel in Core and per Unit Fission Power. in Core at 3-Mw LITR Power vs Excess $\mathrm{H}_{2} \mathrm{SO}_{4}$ Concentration.

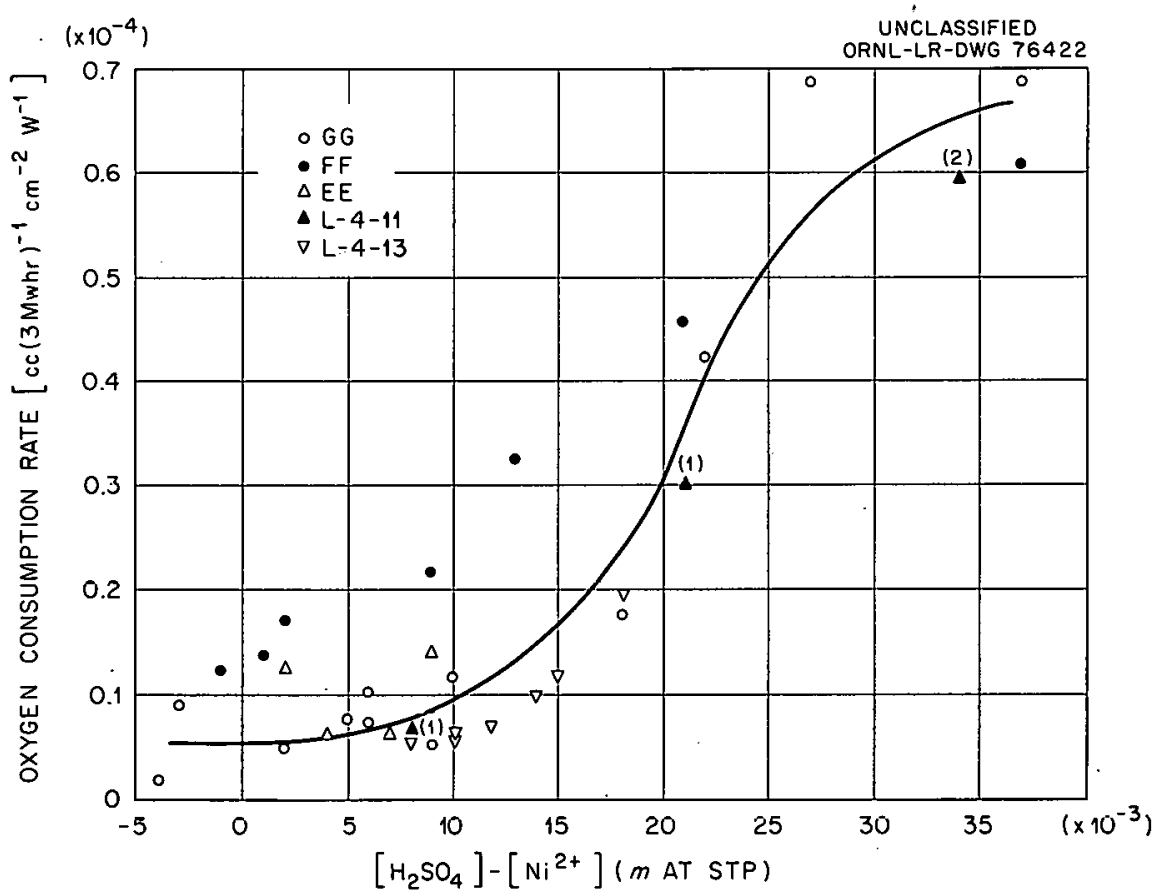

Fig. 86. Rate af $\mathrm{O}_{2}$ Consumption per Unit Area of Exposed Steel in Core and per Unit Fission Power in Core of 3-Mw LITR Power vs $\mathrm{H}_{2} \mathrm{SO}_{4}$ Concentration Less $\mathrm{NiSO}_{4}$ Concentration. 
86, the rate values are plotted vs the concentrations of excess $\mathrm{H}_{2} \mathrm{SO}_{4}$ less the concentration of $\mathrm{NiSO}_{4}$. Set forth in Table 45 are values for the concentrations of excess $\mathrm{H}_{2} \mathrm{SO}_{4}$ and $\mathrm{NiSO}_{4}$ and for the difference between these values at the time of the break in rate of total oxygen consumption. Two values for each quantity are given for experiments FF and L-4-11. The break in the consumption rates in the se experiments occurred during long periods of operation with the reactor down, and appreciable changes in acid and nickel concentrations occurred during these periods. The two values in each case are those for the concentrations at the beginning and the end of the reactor-down period.

Steel areas and fission-power values used in the average rate calculations are listed in Table 46. The acidity values are those obtained from $\mathrm{pH}$ measurements of loop solution samples. The data from loop DD

Table 45. Correlations Between Solution Composition and Occurrence of Break in Oxygen Consumption Rate

\begin{tabular}{|c|c|c|c|c|}
\hline Experiment & $\begin{array}{c}\text { Radiation Exposure } \\
\text { at Time of } \\
\text { Break (Mwhr) }\end{array}$ & $\begin{array}{c}\text { Concentration of } \\
\text { Excess } \mathrm{H}_{2} \mathrm{SO}_{4} \\
(M \text { at STP })\end{array}$ & $\begin{array}{c}{\left[\mathrm{Ni}^{2+}\right]} \\
(M \text { at } \mathrm{STP})\end{array}$ & $\begin{array}{c}\text { Excess } \mathrm{H}_{2} \mathrm{SO}_{4} \\
\text { Less }\left[\mathrm{Ni}^{2+}\right]^{-} \\
(M \text { at STP })\end{array}$ \\
\hline \multirow[t]{2}{*}{$\mathrm{FF}$} & 540 & $0.023^{a}$ & 0.010 & 0.013 \\
\hline & & $0.021^{a}$ & 0.012 & 0.009 \\
\hline GG & 330 & $0.019^{a}$ & 0.010 & 0.009 \\
\hline EE & 300 & $0.010^{a}$ & 0.002 & 0.008 \\
\hline$L-4-13^{b}$ & 590 & $0.020^{c}$ & 0.006 & 0.014 \\
\hline$L-4-11$ & 200 & $0.034^{a}$ & 0.015 & 0.019 \\
\hline (1st solution) & & $0.030^{a}$ & 0.020 & 0.010 \\
\hline
\end{tabular}

${ }^{a}$ Determined from $\mathrm{pH}$ measurements.

${ }^{b}$ Solvent $\mathrm{D}_{2} \mathrm{O}$. All other experiments employed $\mathrm{H}_{2} \mathrm{O}$ solvent.

${ }^{c}$ From analytical determinations of free acid.

Table 46. Steel Areos and Fission Powers for Loop Experiments

\begin{tabular}{lcccc}
\hline & \multicolumn{3}{c}{ Steel Surface Areas in Core } & Fission Power \\
\cline { 2 - 5 } Experiment & $\begin{array}{c}\text { Core Body } \\
\left(\mathrm{cm}^{2}\right)\end{array}$ & $\begin{array}{c}\text { Exposed Specimen } \\
\text { Surface } \\
\left(\mathrm{cm}^{2}\right)\end{array}$ & $\begin{array}{c}\text { Total } \\
\text { Area } \\
\left(\mathrm{cm}^{2}\right)\end{array}$ & $\begin{array}{c}\text { LiTR Power } \\
(\mathrm{w})\end{array}$ \\
\hline FF & 445 & 0 & 445 & 606 \\
GG & 445 & 0 & 445 & 830 \\
EE & 445 & 201 & 646 & 528 \\
L-4-13 & 318 & 195 & 513 & 690 \\
L-4-11 & 445 & 255 & 700 & 810 \\
\hline
\end{tabular}


were excluded from this comparison because the loop solution was diluted with water during the exposure. Each of the other solutions was about $0.17 \mathrm{~m} \mathrm{UO}_{2} \mathrm{SO}_{4}$ and $0.03 \mathrm{~m} \mathrm{CuSO}_{4}$ throughout the exposure. The rate values for experiments FF, GG, EE, and L-4-13 were calculated from the values shown in Fig. 85 , and all data points are plotted. For experiment $L-4-11$ the data points labeled (1) were obtained shortly after the initiation of irradiation with the first solution, which contained the $\mathrm{NiSO}_{4}$ additive. The point labeled (2) was obtained near the start of irradiation with the second solution, which contained no $\mathrm{NiSO}_{4}$.

The average corrosion rate per unit area of exposed steel surface in the core was selected for comparisons in Figs. 85 and 86 , because, as discussed in previous paragraphs, most of the accelerated steel corrosion under irradiation occurred in the core, and it appears reasonable to assume that the average rate of oxygen consumption in the core was roughly proportional to the total steel area. The true relationship between power density and the average steel corrosion rate is unknown. However, the average rate on specimens increased with increasing power density, and, for the small differences in power density involved ( 530 to $830 \mathrm{w}$ total with core volumes about equal), it appears reasonable to assume a linear increase in average rate with increasing power density for all steel surfaces in the cores.

Most of the data plotted in Fig. 85 group together and tend to support the concept of a direct correlation between average rate and acidity. Some of the spread of the values probably resulted from differences between background rates for different experiments. For example, the corrosion of the pinhole weld in the core of loop FF probably increased the total oxygen consumption substantially throughout the exposure. However, the two data points for the L-4-11 solution with added $\mathrm{NiSO}_{4}$ are obviously out of line and, in comparison with the other data, show that the $\mathrm{NiSO}_{4}$ addition effected a reduction of the steel corrosion rate under irradiation.

The rate as plotted in Fig. 86 indicates that for the data from experiments GG, EE, L-4-13, and L-4-11, a somewhat better correlation exists between the rate and the difference between the concentrations of excess $\mathrm{H}_{2} \mathrm{SO}_{4}$ and $\mathrm{NiSO}_{4}$ than between the rate and excess $\mathrm{H}_{2} \mathrm{SO}_{4}$. The $\mathrm{FF}$ values are separated from the others to a greater extent than in Fig. 85. However, as mentioned previously, it is possible that localized attack tended to produce relatively higher rates in FF.

The data set forth in Table 45 show that the concentrations of excess acid ranged from about 0.01 to $0.03 \mathrm{~m}$ at the occurrence of the break in rate of total oxygen consumption for the several experiments, and no direct correlation between the two factors is apparent. However, the values for the difference between the concentrations of excess acid and $\mathrm{NiSO}_{4}$ at the breaks are apparently in better agreement. Assuming that the minimum values for $F F$ and L-4-11 represent the concentrations at the occurrence of the breaks, the values for the differences are between 0.008 and 0.010 for the $\mathrm{H}_{2} \mathrm{O}$ experiments $F F, G G, E E$, and $\mathrm{L}-4-11$, while the value for the $\mathrm{D}_{2} \mathrm{O}$ experiment, $\mathrm{L}-4-13$, is 0.014 .

On the basis of the above considerations, it is concluded that the average rate of steel corrosion in the in-pile loop cores in the several $250^{\circ} \mathrm{C}$ experiments was dependent upon the concentrations of excess $\mathrm{H}_{2} \mathrm{SO}_{4}$ and of $\mathrm{NiSO}_{4}$, with the rate decreasing with decreasing acid and with increasing $\mathrm{NiSO}_{4}$. The explanation for these effects which is considered most likely is that the corrosion was influenced by the hydrogen ion concentration at the exposure temperature, and that the $\mathrm{NiSO}_{4}$ in solution tended to reduce 
this concentration through the formation of $\mathrm{HSO}_{4}^{-}$. The latter ion is known to be very stable at $250^{\circ} \mathrm{C} .{ }^{41}$ The true extent to which $\mathrm{NiSO}_{4}$ influenced the hydrogen ion concentration is unknown. However, for purposes of estimating corrosion in solutions of these particular concentrations of $\mathrm{UO}_{2} \mathrm{SO}_{4}$ and $\mathrm{CuSO}_{4}$ at $250^{\circ} \mathrm{C}$, it can be assumed that the excess acid is consumed mole for mole by the $\mathrm{NiSO}_{4}$. More data at other solution concentrations and temperatures will be required to evaluate the effects of $\mathrm{H}_{2} \mathrm{SO}_{4}$ and $\mathrm{NiSO}_{4}$ at other conditions. (Such data are available but have not yet been analyzed for the effects.)

It may be noted that on the basis of the above interpretation of the effects of $\mathrm{NiSO}_{4}$, other corrosion products would be expected to exercise similar effects if they were dissociated at the exposure temperature. However, other corrosion products which entered solution and which might be in this category, for example, manganese and iron, were present at low concentrations and could be neglected. Changes in $\mathrm{CuSO}_{4}$ concentrations during exposure or differences in concentration between experiments, if sufficiently large, might also affect the relative acidities and corrosion rates. However, these differences were small and can be neglected to a first approximation.

All the discussion of the effect of acid on corrosion has been related to the average corrosion rate of steel in the loop cores within which the fission-power densities varied by factors of 4 to 5 from the front to the rear. The data are not sufficient to determine either the rate prevailing for a surface at a given power density and solution composition or the effects of changes in these variables on the rates.

Although the steel data presented here have been reported and discussed elsewhere, it should be noted that the correlations between solution acidity, nickel accumulation in solution, and solution velocity and steel corrosion were not yet formulated. Consequently, some of the previously reported data from these and subsequent loop experiments may require reconsideration.

\subsection{Corrosion of Zircaloy-2 and Crystal-Bar Zirconium}

Data for the corrosion of these materials have been previously reviewe $d^{42}$ and correlated with other data from loop and autoclave experiments, and they are not discussed further in this report.

\subsection{Corrosion of Titanium Alloys}

Fewer corrosion data are available for these alloys than for stainless steels and zirconium alloys. The available data have been reviewed previously 43,44 and are not discussed further in this report.

\footnotetext{
${ }^{41}$ M. H. Lietzke, R. W. Stoughton, and T. F. Young, "The Bisulfate Acid Constant from $25^{\circ}$ to $225^{\circ} \mathrm{C}$, as Computed from Solubility Data," to be published in the Joumal of Pbysical Chemistry.

${ }^{42}$ G. H. Jenks, Review and Correlation of In-Pile Zircaloy-2 Corrosion Data and a Model for the Effect of lrradia. tion, ORNL-3039 (July 1961). tion).

${ }^{43}$ G. H. J enks and J. E. Baker, HRP Radiation Corrosion Studies: In-Pile Loop L-2-17. ORNL-2974 (in prepara-

${ }^{44}$ G. H. Jenks and J. E. Baker, In-Pile Loop Investigation of Corrosion of Zircaloy-2 and Other Reactor Materials in $0.04 \mathrm{~m} \mathrm{UO}_{2} \mathrm{SO}_{4}$ at $280^{\circ} \mathrm{C}$, ORNL-2962, in press.
} 


\section{ORNL-3131}

UC-25 - Metal s, Ceramics, and Materials TID-4500 (20th ed., Rev.)

INTERNAL DISTRIBUTION

1. G. M. Adamson

2. A. L. Bacarella

3. J. E. Baker

4. J. M. Baker

5. S. E. Beall

6. E. G. Bohlmann

7. S. E. Bolt

8. G. E. Boyd

9. R. B. Briggs

10. W. D. Burch

11. T. A. Butler

12. W. E. Clark

13. E. L. Compere

14. F. L. Culler

15. R. J. Davis

16. V. A. DeCarlo

17. J. L. English

18. D. E. Ferguson

19. J. H Frye, Jr.

20. W. R. Gall

21. J. C. Griess

22. W. R. Grimes

23. P. N. Haubenreich

24. J. W. Hill, Jr.

25. G. H. Jenks

26. M. T. Kelley

27. M. J. Kelly

28. R. B. Korsmeyer

29. J. A. Lane
30. C. E. Larson

31. C. G. Lawson

32. R. A. Lorenz

33. R. N. Lyon

34. W. L. Marshall

35. J. P. McBride

36. R. E. McDonald

37. H. F. McDuffie

38. J. R. McWherter

39. A. R. Olsen

40. J. R. Parrott

41. M. L. Picklesimer

42. H. C. Savage

43. M. J. Skinner

44. I. Spiewak

45. J. A. Swartout

46. A. Taboada

47. E. H. Taylor

48. G. M. Watson

49. A. M. Weinberg

50. F. Daniels (consultant)

51. F. T. Gucker (consultant)

52. F. T. Miles (consultant)

53-54. Central Research Library

55. Reactor Division Library

56-75. Laboratory Records Department

76. Laboratory Records, ORNL RC

77-78. ORNL-Y-12 Technical Library, Document Reference Section

\section{EXTERNAL DISTRIBUTION}

79. Research and Development Division, AEC, ORO

80-658. Given distribution os shown in TID-4500 (20th ed., Rev.) under Metals, Ceramics, and Materials Category (75 copies - OTS) 